DOC.20041018.0010

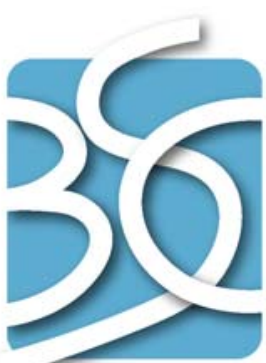

BECHTEL SAIC COMPANYLC

QA: QA

ANL-NBS-MD-000014 REV 00

October 2004

NOTICE OF OPEN CHANGED DOCUMENTS - THIS DOCUMENT IS IMPACTED BY THE LISTED CHANGE DOCUMENTS AND CANNOT BE USED WITHOUT THEM.

1) ACN-001, DATED 04/28/2005

\title{
Biosphere Dose Conversion Factor Importance and Sensitivity Analysis
}

Prepared for:

U.S. Department of Energy

Office of Civilian Radioactive Waste Management

Office of Repository Development

1551 Hillshire Drive

Las Vegas, Nevada 89134-6321

Prepared by:

Bechtel SAIC Company, LLC

1180 Town Center Drive

Las Vegas, Nevada 89144

Under Contract Number

DE-AC28-01RW12101 


\section{DISCLAIMER}

This report was prepared as an account of work sponsored by an agency of the United States Government. Neither the United States Government nor any agency thereof, nor any of their employees, nor any of their contractors, subcontractors or their employees, makes any warranty, express or implied, or assumes any legal liability or responsibility for the accuracy, completeness, or any third party's use or the results of such use of any information, apparatus, product, or process disclosed, or represents that its use would not infringe privately owned rights. Reference herein to any specific commercial product, process, or service by trade name, trademark, manufacturer, or otherwise, does not necessarily constitute or imply its endorsement, recommendation, or favoring by the United States Government or any agency thereof or its contractors or subcontractors. The views and opinions of authors expressed herein do not necessarily state or reflect those of the United States Government or any agency thereof. 
QA: QA

Biosphere Dose Conversion Factor Importance and Sensitivity Analysis

\section{ANL-NBS-MD-000014 REV 00}

October 2004 


\begin{tabular}{|l|l|l|}
\hline \multirow{2}{*}{ OCRWM } & Scientific Analysis Signature Page/ Change History & Page iii \\
\cline { 3 - 3 } & & 1. Total Pages: 158 \\
\hline
\end{tabular}

2. Scientific Analysis Title

Biosphere Dose Conversion Factor Importance and Sensitivity Analysis

3. DI (including Revision Number)

ANL-NBS-MD-000014 REV 00

4. Total Appendices

5. Number of Pages in Each Appendix

One (1)

\begin{tabular}{|l|}
\hline \\
\hline 6. Originator \\
\hline
\end{tabular}

7. Checker

8. QER

9. Responsible Manager/Lead

10. Responsible Manager

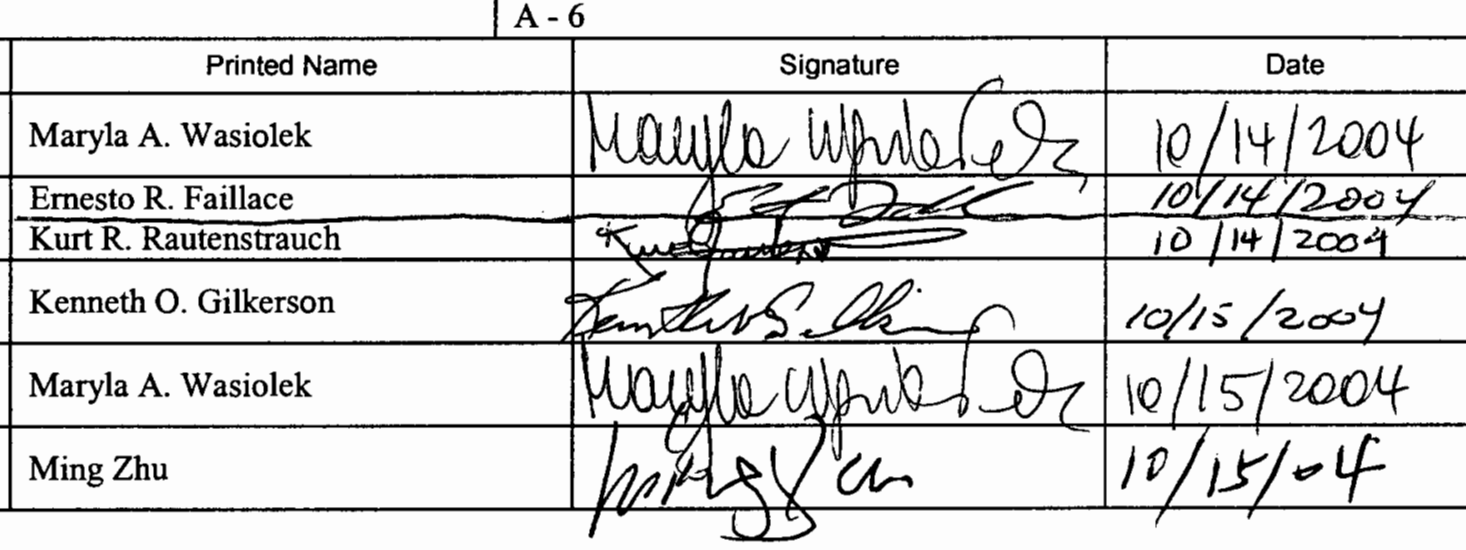

11. Remarks

\section{Change History}

\begin{tabular}{|l|l|}
\hline 12. Revision No. & 13. Description of Change \\
\hline 00 & Initial issue \\
\hline & \\
\hline & \\
\hline & \\
\hline & \\
\hline
\end{tabular}




\section{CONTENTS}

Page

ACRONYMS AND ABBREVIATIONS ......................................................................... xiii

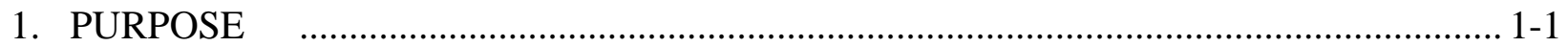

2. QUALITY ASSURANCE ................................................................................... 2-1

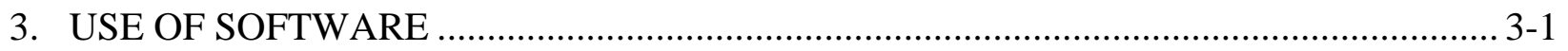

4. INPUTS

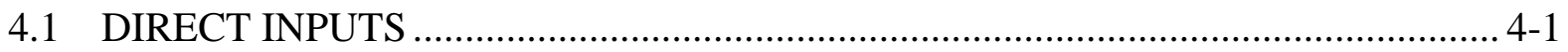

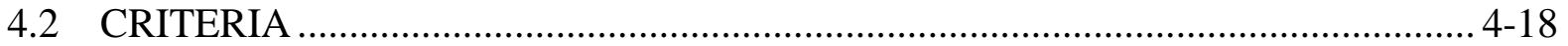

4.3 CODES, STANDARDS, AND REGULATIONS ............................................. 4-21

5. ASSUMPTIONS ................................................................................................

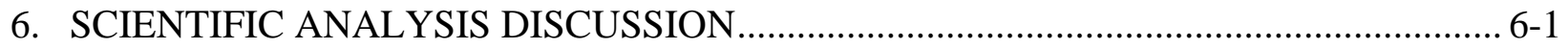

6.1 GENERAL CONSIDERATIONS .................................................................. 6-1

6.1.1 Radionuclides Included in the Analysis................................................... 6-1

6.1.2 Description of the Exposure Scenarios .................................................... 6-2

6.1.3 Receptor Used in the Biosphere Model ........................................................ 6-3

6.1.4 Consideration of Climate Change .......................................................... 6-4

6.1.5 Biosphere Model ................................................................................. 6-4

6.2 IDENTIFICATION OF IMPORTANT PATHWAYS, PROCESSES AND

PARAMETERS FOR THE GROUNDWATER EXPOSURE SCENARIO................ 6-5

6.2.1 Distributions of Biosphere Dose Conversion Factors...................................... 6-5

6.2.2 Summary of Pathway Analysis Results .................................................... 6-12

6.2.3 Sources of Uncertainty in the Biosphere Dose Conversion Factors ............... 6-17

6.2.3.1 Correlation Statistics for the Selected Radionuclides ................... 6-17

6.2.3.2 Calculation of Correlation Statistics for Stochastic Input

Parameters and Biosphere Dose Conversion Factors .................... 6-21

6.2.4 Analysis of the Environmental Transport Pathways and Radionuclide

Accumulation in the Environmental Media.............................................. 6-23

6.2.4.1 Radionuclide Accumulation in Surface Soil ................................. 6-24

6.2.4.2 Radionuclide Transport to Air.................................................... 6-34

6.2.4.2.1 Operation of Evaporative Coolers............................. 6-34

6.2.4.2.2 Resuspension of Surface Soil.................................. 6-38

6.2.4.3 Radionuclide Transport to Crops .................................................. 6-43

6.2.4.4 Radionuclide Transport to Animal Products .................................. 6-53

6.2.4.5 Radionuclide Transport to Aquatic Food ...................................... 6-59

6.2.5 Analysis of the Receptor Exposure Pathways .......................................... 6-59

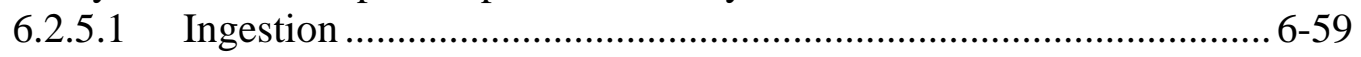

6.2.5.2 Inhalation..................................................................... 6-61

6.2.5.2.1 Inhalation of Particulate Matter ................................ 6-62 


\section{CONTENTS (Continued)}

\subsection{Inhalation of Aerosols Generated by Evaporative}

Coolers .................................................................... 6-65

6.2.5.3 External Exposure .................................................................... 6-67

6.3 IDENTIFICATION OF IMPORTANT PATHWAYS, PROCESSES AND PARAMETERS FOR VOLCANIC ASH EXPOSURE SCENARIO ....................... 6-67

6.3.1 Distributions of Biosphere Dose Conversion Factors................................... 6-67

6.3.2 Summary of Pathway Analysis................................................................ 6-72

6.3.3 Sources of Uncertainty in the Biosphere Dose Conversion Factors ............... 6-75

6.3.4 Analysis of the Environmental Transport Pathways and Radionuclide Accumulation in the Environmental Media.................................................... 6-79

6.3.4.1 Radionuclide Accumulation in Surface Soil ................................. 6-79

6.3.4.2 Radionuclide Transport to Air.................................................... 6-80

6.3.4.3 Radionuclide Transport to Crops ................................................... 6-83

6.3.4.4 Radionuclide Transport to Animal Products ................................ 6-84

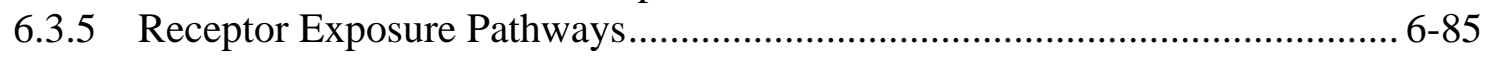

6.3.5.1 Inhalation Pathway ................................................................... 6-85

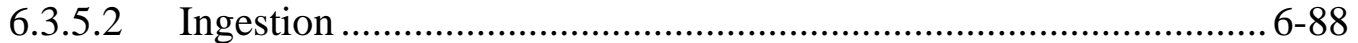

6.3.5.3 External Exposure .................................................................... 6-89

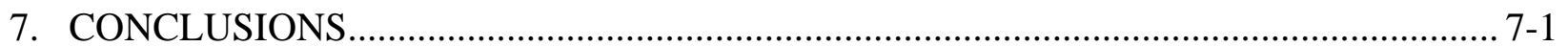

7.1 SUMMARY OF FINDINGS .......................................................................... 7-1

7.1.1 Groundwater Exposure Scenario .......................................................... 7-1

7.1.2 Volcanic Ash Exposure Scenario......................................................................... 7-4

7.2 HOW THE ACCEPTANCE CRITERIA WERE ADDRESSED............................... 7-5

8. INPUTS AND REFERENCES ............................................................................... 8-1

8.1 DOCUMENTS CITED .................................................................................. 8-1

8.2 CODES, STANDARDS, REGULATIONS, AND PROCEDURES .......................... 8-2

8.3 SOURCE DATA, LISTED BY DATA TRACKING NUMBER ….......................... 8-3

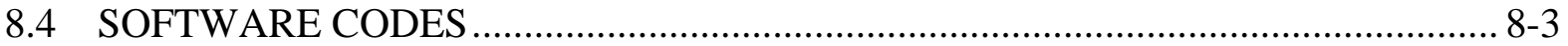

APPENDIX A - LIST AND DESCRIPTION OF FILES GENERATED IN THIS

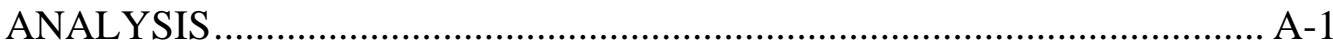




\section{FIGURES}

1-1. Biosphere Model Documentation and Total System Performance Assessment Feeds

6.2-1. BDCF Distributions for the Groundwater Exposure Scenario and the Present-Day Climate

6.2-2. BDCF Distributions for the Groundwater Exposure Scenario and the Present-Day Climate Sorted by the Mean BDCF Value.

6.2-3. BDCF Distributions for Groundwater Exposure Scenario, Present-Day Climate, Normalized to the Mean Value

6.2-4. Distributions of the BDCFs (Exclusive of the Drinking Water Component) for Groundwater Exposure Scenario, Present-Day Climate, Normalized to the Mean Value.

6.2-5. Pathway Contributions for the Groundwater Exposure Scenario and Present-Day Climate....

6.2-6. Pathway Contributions for the Groundwater Exposure Scenario and Future Climate....

6.2-7. Uncertainty Associated with the Major Exposure Pathways for Selected Radionuclides.

6.2-8. Dependence of BDCF for the Groundwater Exposure Scenario and Present-Day Climate on Annual Average Irrigation Rate

6.2-9. Dependence of BDCF for the Groundwater Exposure Scenario and Present-Day Climate on Soil Erosion Rate.

6.2-10. Dependence of BDCF for the Groundwater Exposure Scenario and Present-Day Climate on Overwatering Rate.

6.2-11. Dependence of BDCF for the Groundwater Exposure Scenario and Present-Day Climate on $\mathrm{K}_{\mathrm{d}} \mathrm{S}$

6.2-12. Dependence of BDCF for the Groundwater Exposure Scenario and the Present-Day Climate on the Water Transfer Fraction for Evaporative Coolers ...... 6-35

6.2-13. Dependence of BDCF for the Groundwater Exposure Scenario and the Future Climate on the Water Transfer Fraction for Evaporative Coolers.

6.2-14. Average Radionuclide Concentration in Air from Resuspension of Soil by Radionuclide and Environment.

6.2-15. Average Particulate Concentration in Air (Mass Loading) in the Receptor Environments

6.2-16. Average Enhancement Factor in the Receptor Environments 6-40

6.2-17. Dependence of BDCF for the Groundwater Exposure Scenario and the Present-Day Climate on the Atmospheric Mass Loading for the Active Outdoors Environment.

6.2-18. Dependence of BDCF for the Groundwater Exposure Scenario and the Present-Day Climate on the Atmospheric Mass Loading for the Inactive Outdoors Environment.

6.2-19. Environmental Transport Pathway Contributions for Groundwater Exposure Scenario and Present Day Climate Averaged for All Crop Types. 


\section{FIGURES (Continued)}

6.2-20. Water Interception Fraction Histograms by Crop Type Resulting from 1,000 Model Realizations of the Biosphere Model

6.2-21. Dependence of ${ }^{99}$ Tc BDCF for the Groundwater Exposure Scenario and Present-Day Climate on Water Interception Fraction by Type of Crops for Human Consumption

6.2-22. Dependence of BDCFs for ${ }^{99}$ Tc for the Groundwater Exposure Scenario and the Present-Day Climate on Transfer Factors by Crop Type....

6.2-23. Dependence of BDCF for ${ }^{237} \mathrm{~Np}$ for the Groundwater Exposure Scenario and the Present-Day Climate on Transfer Factors by Crop Type.

6.2-24. Average Contributions of Environmental Transport Pathways to Radionuclide Transport to Meat and Milk

6.2-25. Average Contributions of Environmental Transport Pathways to Radionuclide Transport to Poultry and Eggs ...

6.2-26. Dependence of BDCF for ${ }^{99}$ Tc for the Groundwater Exposure Scenario and the Present-Day Climate on Transfer Coefficients by Animal Product.

6.2-27. Dependence of BDCF for ${ }^{99}$ Tc for the Groundwater Exposure Scenario and the Present-Day Climate on Animal Feed Consumption Rates by Animal Product.

6.2-28. Average Fraction of Dose from Particulate Inhalation by Radionuclide and Environment.

6.2-29. Average Weighted Time Spent in the Receptor Environments for Groundwater Exposure Scenario

6.2-30. Breathing Rates in the Receptor Environments .. 6-64

6.2-31. Dependence of the BDCFs for Selected Actinides on the Population Weighted Time Spent in the Active Outdoors Environment.

6.3-1. Distributions of the Ingestion-Radon-External Exposure Component of the BDCFs for the Volcanic Ash Exposure Scenario

6.3-2. Distributions of the Short-Term Inhalation Component of the BDCFs for Volcanic Ash Exposure Scenario.

6.3-3. Distributions of the Long-Term Inhalation Component of the BDCFs for Volcanic Ash Exposure Scenario.

6.3-4. Average Percent BDCF Pathway Contributions for Volcanic Ash Exposure Scenario for Time $=0$ and Ash Thickness Equal or Less than Critical Thickness for Selected Radionuclides ....

6.3-5. Average Percent BDCF Pathway Contributions for Volcanic Ash Exposure Scenario for Time $=0$ and Ash Thickness 10 Times Greater Than Critical Thickness for Selected Radionuclides

6.3-6. Dependence of Short-Term Inhalation BDCF Component for ${ }^{241} \mathrm{Am}$ on Critical Thickness

6.3-7. Average Radionuclide Concentration in Air by Receptor Environment Used in Calculation of Short-Term and Long-Term Inhalation BDCF Component. 


\section{FIGURES (Continued)}

6.3-8. $\quad$ Average Atmospheric Mass Loading by Receptor Environment Used in Calculation of Short-Term (Mass Loading for Ash) and Long-Term (Nominal Mass Loading) Inhalation BDCF Component

6.3-9. Average Enhancement Factor by Receptor Environment Used in Calculation of the Short-Term and Long-Term Inhalation BDCF Component

6.3-10. Dependence of Short-Term Inhalation BDCF Component for ${ }^{241} \mathrm{Am}$ on Ash Mass Loading in the Active Outdoors Environment.

6.3-11. Dependence of Long-Term Inhalation BDCF Component for ${ }^{241} \mathrm{Am}$ on Nominal Mass Loading in the Active Outdoors Environment

6.3-12. Fractional Contributions of the Receptor Environments to the Short-Term and Long-Term BDCF Components.

6.3-13. Weighted Time Spent in the Receptor Environments for Volcanic Ash Exposure Scenario

6.3-14. Dependence of Short-Term Inhalation BDCF Component for ${ }^{241} \mathrm{Am}$ on Proportion of Outdoor Workers ....

A-1. GoldSim Files for Stochastic Runs of the Biosphere Model for the Groundwater and Volcanic Ash Exposure Scenarios

A-2. GoldSim Files for Deterministic Runs of the Biosphere Model for the Groundwater and Volcanic Ash Exposure Scenarios .... A-1

A-3. List of the Excel Files Supporting this Analysis. A-2 


\section{INTENTIONALLY LEFT BLANK}




\section{TABLES}

Page

1-1. $\quad$ Biosphere-Related Features, Events, and Processes Included in TSPA ................... 1-3

4.1-1. Summary of Input Parameter Values Used in Deterministic Model Runs ............... 4-2

4.1-2. $\quad$ Primary Radionuclides and Their Decay Products Included in the Biosphere Model

4.1-3. Dose Conversion Factors for Inhalation and Ingestion of Radionuclides of

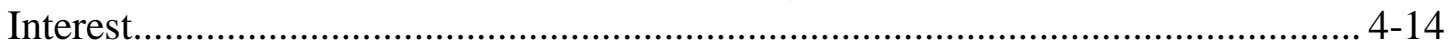

4.1-4. Dose Coefficients for Exposure to Contaminated Soil for Radionuclides of

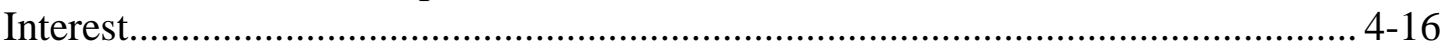

4.2-1. $\quad$ Applicable Project Requirements and Acceptance Criteria .................................. 4-18

6.1-1. Primary Radionuclides and Decay Products Included in the Biosphere Dose Conversion Factors

6.2-1. Exposure Pathway Contributions (Percent) for the Present-Day Climate Biosphere Dose Conversion Factors

6.2-2. Exposure Pathway Contributions (Percent) for the Future Climate Biosphere Dose Conversion Factors

6.2-3. Correlation Coefficients for the Input Parameters and Biosphere Dose Conversion Factors for the Groundwater Exposure Scenario and the Present-Day Climate....

6.2-4. Correlation Coefficients between BDCF Values for ${ }^{99}$ Tc and Input Parameters with Absolute Values Greater than 0.125 ....

6.2-5. Observed Correlation Coefficients between ${ }^{99}$ Tc BDCF Values and Input Parameters for Other Radionuclides ....

6.2-6. The Number of Expected and Observed False Correlation Values for Independent Input Parameters as a Function of Confidence Level

6.2-7. BDCF and Percent Change from Average for Different Levels of Annual Average Irrigation Rate.

6.2-8. BDCFs and Percent Change for Different Levels of Activity Concentration in Air from Operation of Evaporative Coolers ....

6.2-9. BDCF and Percent Change for Different Levels of Mass Loading for the Active Outdoors Environment.

6.2-10. Fractions of Activity in Crop Types from Considered Environmental Transport Pathways for Groundwater Exposure Scenario for Present-Day Climate.

6.2-11. Fractions of Activity in Crop Types from Considered Environmental Transport Processes for Groundwater Exposure Scenario for Future Climate........ 6-45

6.2-12 Irrigation Interception Fractions Used in Calculations ...................................... 6-49

6.2-13. BDCFs and Percent Change for Different Irrigation Interception Fractions .......... 6-49

6.2-14. Fractions of Activity in Animal Products from Environmental Transport Pathways for Groundwater Exposure Scenario for Present-Day Climate ............... 6-53

6.2-15. Fractions of Activity in Animal Products from Environmental Transport Pathways for Groundwater Exposure Scenario for the Future Climate. 6-55 


\section{TABLES (Continued)}

Page

6.2-16. Annual Consumption Rates of Locally Produced Food Used in the Evaluation..... 6-60

6.2-17. BDCFs for Different Levels of Consumption of Locally Produced Food.............. 6-61

6.3-1. $\quad$ Exposure Pathway Contributions (Percent) for the Mean Volcanic Ash Exposure Scenario BDCFs for the Present-Day Climate

6.3-2 Correlation Coefficients for Input Parameters and the Ingestion-RadonExternal Exposure Component of Biosphere Dose Conversion Factors for the Volcanic Ash Exposure Scenario.

6.3-2 Correlation Coefficients for the Input Parameters and Ingestion-RadonExternal Exposure Component of Biosphere Dose Conversion Factors for the Volcanic Ash Exposure Scenario (Continued)

6.3-3. Correlation Coefficients for the Input Parameters and Inhalation Components of Biosphere Dose Conversion Factors for the Volcanic Ash Exposure Scenario.....

6.3-4. Inhalation BDCF Components for ${ }^{241} \mathrm{Am}$ and Percent Change for Different Levels of Mass Loading in the Active Outdoors Environment

6.3-5. Inhalation BDCF Components for ${ }^{241} \mathrm{Am}$ and Percent Change for Different Levels of Mass Loading in the Inactive Outdoors Environment.

6.3-6. Fractions of Activity in Crops from Environmental Transport Processes for the Volcanic Ash Exposure Scenario.

6.3-7. Fractions of Activity in Animal Products from Environmental Transport Processes for the Volcanic Ash Exposure Scenario

6.3-8. Effect of a Change in the Daily Exposure Time in the Active Outdoor Environment for Outdoor Workers on the Long-Term Inhalation BDCF Component for ${ }^{241} \mathrm{Am}$

6.3-9. Base Case and Modified Times Spent in Receptor Environments by Population Groups $6-88$ 


\section{ACRONYMS AND ABBREVIATIONS}

BDCF biosphere dose conversion factor

ERMYN environmental radiation model for Yucca Mountain, Nevada

FEP feature, event, and process

$\mathrm{K}_{\mathrm{d}} \quad$ partition coefficient

LA license application

QA quality assurance

RMEI reasonably maximally exposed individual

TSPA total system performance assessment 


\section{INTENTIONALLY LEFT BLANK}




\section{PURPOSE}

This report presents importance and sensitivity analysis for the environmental radiation model for Yucca Mountain, Nevada (ERMYN). ERMYN is a biosphere model supporting the total system performance assessment (TSPA) for the license application (LA) for the Yucca Mountain repository. This analysis concerns the output of the model, biosphere dose conversion factors (BDCFs) for the groundwater, and the volcanic ash exposure scenarios. It identifies important processes and parameters that influence the BDCF values and distributions, enhances understanding of the relative importance of the physical and environmental processes on the outcome of the biosphere model, includes a detailed pathway analysis for key radionuclides, and evaluates the appropriateness of selected parameter values that are not site-specific or have large uncertainty.

The documentation hierarchy for the ERMYN is presented in Figure 1-1. This figure shows the interrelationships among the products (i.e., analysis and model reports) developed for biosphere modeling. The Biosphere Model Report (BSC 2004 [DIRS 169460]) describes in detail the ERMYN conceptual model and mathematical model. The input parameter reports (BSC 2004 [DIRS 169671]; BSC 2004 [DIRS 169672]; BSC 2004 [DIRS 169673]; BSC 2004 [DIRS 169458]; and BSC 2004 [DIRS 169459]) contain detailed descriptions of the model input parameters and their development. Outputs from these six reports are used in the Nominal Performance Biosphere Dose Conversion Factor Analysis (BSC 2004 [DIRS 169674]) and Disruptive Event Biosphere Dose Conversion Factor Analysis (BSC 2004 [DIRS 167287]) to generate the BDCFs, which are input parameters for the TSPA model. This report analyzes the output of these two BDCF reports. The analysis was performed in accordance with the technical work plan (BSC 2004 [DIRS 169573]).

The biosphere model considers features, events, and processes (FEPs) applicable to the Yucca Mountain biosphere (DTN: MO0407SEPFEPLA.000 [DIRS 170760]). Consideration of the $L A$ FEP List (DTN: MO0407SEPFEPLA.000 [DIRS 170760]) constitutes a deviation from the Technical Work Plan for Biosphere Modeling and Expert Support (BSC 2004 [DIRS 169573]), which referred to an earlier revision of the FEPs list (DTN: MO0307SEPFEPS4.000 [DIRS 164527]). In addition, the list of Yucca Mountain Review Plan acceptance criteria (NRC 2003 [DIRS 163274]) applicable to this analysis differs from the list provided in the technical work plan (BSC 2004 [DIRS 169573]).

The disposition of these FEPs in the TSPA is through the BDCFs, which are direct inputs to the TSPA model. Table 1-1 lists FEPs that are included in the biosphere model (BSC 2004 [DIRS 169460], Table 6.2-1). Relationships among the biosphere-related FEPs, the biosphere conceptual model, and the exposure scenarios are examined in Section 6.3 of the Biosphere Model Report. The disposition of the included FEPs within the mathematical model and their relationship to the model equations and input parameters are presented in Table 6.7-1 of the Biosphere Model Report (BSC 2004 [DIRS 169460]). 


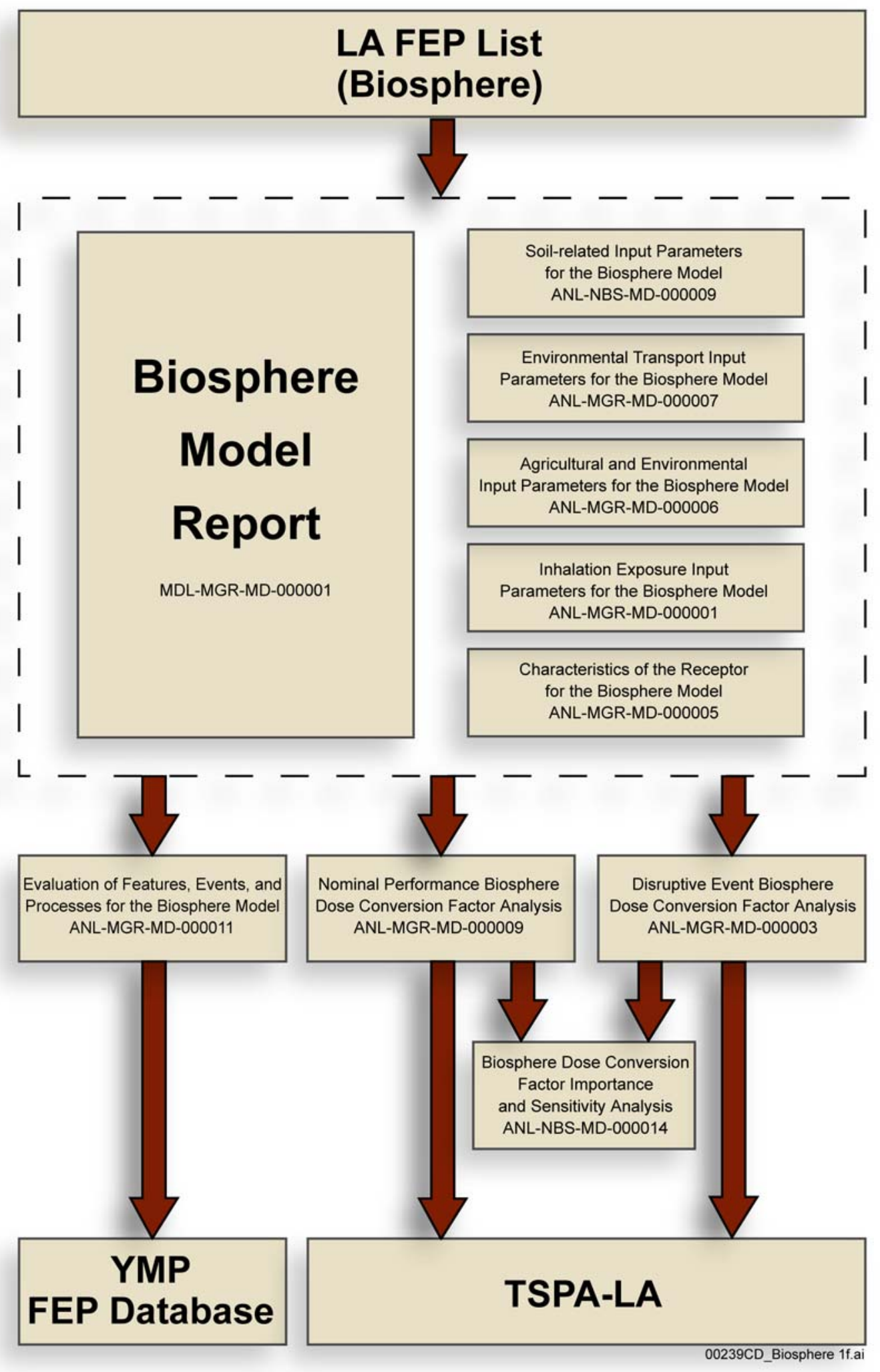

Figure 1-1. Biosphere Model Documentation and Total System Performance Assessment Feeds 
Table 1-1. Biosphere-Related Features, Events, and Processes Included in TSPA

\begin{tabular}{|c|c|}
\hline FEP Name & LA FEP Number \\
\hline Ashfall & 1.2.04.07.0A \\
\hline Climate change & 1.3.01.00.0A \\
\hline Water table rise affects SZ & 1.3.07.02.0A \\
\hline Water management activities & 1.4.07.01.0A \\
\hline Wells & 1.4.07.02.0A \\
\hline Chemical characteristics of groundwater in the SZ & 2.2.08.01.0A \\
\hline Soil type & 2.3.02.01.0A \\
\hline Radionuclide accumulation in soils & 2.3.02.02.0A \\
\hline Soil and sediment transport in the biosphere & 2.3.02.03.0A \\
\hline Surface water transport and mixing & 2.3.04.01.0A \\
\hline Precipitation & 2.3.11.01.0A \\
\hline Biosphere characteristics & 2.3.13.01.0A \\
\hline Radionuclide alteration during biosphere transport & 2.3.13.02.0A \\
\hline Human characteristics (physiology, metabolism) & 2.4.01.00.0A \\
\hline Human lifestyle & 2.4.04.01.0A \\
\hline Dwellings & 2.4.07.00.0A \\
\hline Wild and natural land and water use & 2.4.08.00.0A \\
\hline Agricultural land use and irrigation & 2.4.09.01.0B \\
\hline Animal farms and fisheries & 2.4.09.02.0A \\
\hline Urban and industrial land and water use & 2.4.10.00.0A \\
\hline Radioactive decay and ingrowth & 3.1.01.01.0A \\
\hline Atmospheric transport of contaminants & 3.2.10.00.0A \\
\hline Contaminated drinking water, foodstuffs and drugs & 3.3.01.00.0A \\
\hline Plant uptake & 3.3.02.01.0A \\
\hline Animal uptake & 3.3.02.02.0A \\
\hline Fish uptake & 3.3.02.03.0A \\
\hline Contaminated non-food products and exposure & 3.3.03.01.0A \\
\hline Ingestion & 3.3.04.01.0A \\
\hline Inhalation & 3.3.04.02.0A \\
\hline External exposure & 3.3.04.03.0A \\
\hline Radiation doses & 3.3.05.01.0A \\
\hline Radon and radon daughter exposure & 3.3.08.00.0A \\
\hline
\end{tabular}

Source: DTN: MO0407SEPFEPLA.000 [DIRS 170760].

$\mathrm{FEP}=$ feature, event, and process, $\mathrm{SZ}=$ saturated zone 


\section{INTENTIONALLY LEFT BLANK}




\section{QUALITY ASSURANCE}

Development of this report involved analysis of data that are used in the TSPA-LA and in the safety analysis report, as identified in the technical work plan (BSC 2004 [DIRS 169573]). Thus, it was a quality affecting activity in accordance with AP-2.27Q, Planning for Science Activities. Approved quality assurance (QA) procedures identified in Section 4 of the technical work plan were used to conduct and document the activities described in this report. Electronic data were controlled in accordance with methods specified in Section 8 of the technical work plan. The governing procedure for the development of this analysis was AP-SIII.9Q, Scientific Analyses.

The natural barriers and items identified in the Q-List (BSC 2004 [DIRS 168361]) are not pertinent to this analysis. Furthermore, a Safety Category per AP-2.22Q, Classification Analyses and Maintenance of the Q-List, is not applicable. 


\section{INTENTIONALLY LEFT BLANK}




\section{USE OF SOFTWARE}

This analysis was performed using the output of the verified and validated ERMYN model, which is described in the Biosphere Model Report (BSC 2004 [DIRS 169460]). The model files were obtained from the Model Warehouse (DTNs: MO0407MWDGSBMF.000 [DIRS 170852]; MO0407MWDGSMFV.000 [DIRS 170856]). The model is implemented using the GoldSim Graphical Simulation Environment, a graphical, object-oriented computer program for carrying out dynamic, probabilistic simulations (GoldSim Technology Group 2003 [DIRS 166226]).

The analysis was conducted using a version of the software qualified under the Office of Civilian Radioactive Waste Management, Quality Assurance program for use on the Yucca Mountain Project: GoldSim Version 8.01 Service Pack (SP) 4 (GoldSim V8.01, STN: 10344-8.01SP4-00) (BSC 2004 [DIRS 169695]). The software was appropriate for the intended use, because it is the program used to execute the model and create the results examined in this report. The software was used within the range of validation in accordance with procedure LP-SI.11Q-BSC, Software Management. GoldSim was installed by Software Configuration Management on a DELL Precision Workstation 530 computer and run under the Windows 2000 operating system.

In addition, the commercial off-the-shelf product Microsoft Excel 2000 (Version 9.0.3821 SR-1) was used for data reduction. Standard functions of Excel were used to calculate values presented in Section 6. The use of these functions, including formulas or algorithms, inputs and outputs is included in the Excel files generated in this analysis shown in Appendix A. These results do not depend on the software program used. 


\section{INTENTIONALLY LEFT BLANK}




\section{INPUTS}

\subsection{DIRECT INPUTS}

This analysis used the results of the biosphere model runs documented in Nominal Performance Biosphere Dose Conversion Factor Analysis (BSC 2004 [DIRS 169674]) and Disruptive Event Biosphere Dose Conversion Factor Analysis (BSC 2004 [DIRS 167287]) and included in the following two DTNs:

MO0407MWDGSBMF.000 [DIRS 170852] GoldSim Biosphere Model Files for Calculating Biosphere Dose Conversion Factors for Groundwater Exposure Scenario

MO0407MWDGSMFV.000 [DIRS 170856] GoldSim Biosphere Model Files for Calculating Biosphere Dose Conversion Factors for Volcanic Ash Exposure Scenario.

From DTN: MO0407MWDGSBMF.000 [DIRS 170852], the GoldSim files for the groundwater exposure scenario for the present-day climate (ERMYN_GW_MC8_<radionuclide symbol>.gsm) and the future climate $\left(E R M Y N_{-} G W_{-} F C 8_{-}<\right.$radionuclide symbol>.gsm $)$were used.

From DTN: MO0407MWDGSMFV.000 [DIRS 170856], the GoldSim files for the volcanic ash exposure scenario for the present-day climate $\left(E R M Y N_{-} V A_{-} M C \delta_{-}<\right.$radionuclide symbol>.gsm $)$ were used.

In addition, deterministic analyses were performed by varying single parameters in the biosphere model. The deterministic parameters were usually included in the model input data files (DTNs: MO0403SPAAEIBM.002 [DIRS 169392]; MO0407SPAINEXI.002 [DIRS 170597]; MO0407SPASRPBM.002 [DIRS 170755]; MO0406SPAETPBM.002 [DIRS 170150]; MO0407SPACRBSM.002 [DIRS 170677]) as the mean (arithmetic or geometric) or median values of the distributions or were calculated as the mean value if a representative deterministic value could not be directly inferred from the distributions given. The input data for the deterministic analyses and their DTNs are listed in Tables 4.1-1 to 4.1-4.

In addition, the consumption rates of locally produced food for an average member of the critical group (CRWMS M\&O 2001 [DIRS 153342], Table 11) were used in Section 6.2.5.1 to determine the impact of change in the consumption rate on the BDCF values. These consumption rates are the product output of a superseded report. However, they were appropriately developed for the receptor previously used in the biosphere model. Because the aim of the comparison carried out in this report is to evaluate how the change in the consumption rates for the two receptors-a hypothetical person called the reasonably maximally exposed individual (RMEI) and an average member of the critical group-propagates onto the model results, these data are suitable and considered qualified for the intended use.

This analysis concerns the input parameters and the outputs of the biosphere model. The files listed in this section contain the input parameters and the modeling results for the biosphere model and are, therefore, appropriate for use in this analysis. 
Table 4.1-1. Summary of Input Parameter Values Used in Deterministic Model Runs

\begin{tabular}{|c|c|c|c|}
\hline \multicolumn{2}{|c|}{ Parameter Name and Unit } & Value & DTN/Reference \\
\hline \multicolumn{4}{|c|}{ SURFACE SOIL } \\
\hline \multicolumn{2}{|c|}{ Concentration of a radionuclide in well water, $\mathrm{Bq} / \mathrm{m}^{3}$} & 1 & Source for groundwater scenario \\
\hline \multicolumn{2}{|c|}{ Radionuclide concentration in ash, $\mathrm{Bq} / \mathrm{m}^{2}$} & 1 & Source for volcanic ash scenario \\
\hline \multicolumn{2}{|c|}{ Annual average irrigation rate, present-day climate, $\mathrm{m} / \mathrm{yr}$} & 0.95 & MO0403SPAAEIBM.002 [DIRS 169392] \\
\hline \multicolumn{2}{|c|}{ Radionuclide half-life and branching fraction } & Table 4.1-2 & MO0407SPACRBSM.002 [DIRS 170677] \\
\hline \multicolumn{2}{|c|}{ Soil bulk density, $\mathrm{kg} / \mathrm{m}^{3}$} & 1500 & MO0407SPASRPBM.002 [DIRS 170755] \\
\hline \multicolumn{2}{|l|}{ Ash settled density, $\mathrm{kg} / \mathrm{m}^{3}$} & 1000 & MO0407SPASRPBM.002 [DIRS 170755] \\
\hline \multicolumn{2}{|c|}{ Surface soil depth (tillage depth), m } & 0.25 & MO0403SPAAEIBM.002 [DIRS 169392] \\
\hline \multicolumn{2}{|c|}{ Surface soil erosion rate, $\mathrm{kg} /\left(\mathrm{m}^{2} \mathrm{yr}\right)$} & 0.49 & MO0407SPASRPBM.002 [DIRS 170755] \\
\hline \multirow{17}{*}{$\begin{array}{l}\text { Soil solid/liquid partition } \\
\text { coefficient, L/kg }\end{array}$} & Carbon & $1.8 \mathrm{E}+01$ & \multirow{17}{*}{ MO0407SPASRPBM.002 [DIRS 170755] } \\
\hline & Chlorine & 1.4E-01 & \\
\hline & Selenium & $1.5 \mathrm{E}+02$ & \\
\hline & Strontium & $2.0 \mathrm{E}+01$ & \\
\hline & Technetium & 1.4E-01 & \\
\hline & Tin & $4.5 \mathrm{E}+02$ & \\
\hline & lodine & $4.5 \mathrm{E}+00$ & \\
\hline & Cesium & 4.4E+03 & \\
\hline & Lead & $1.6 \mathrm{E}+04$ & \\
\hline & Radium & $3.6 \mathrm{E}+04$ & \\
\hline & Actinium & $1.5 \mathrm{E}+03$ & \\
\hline & Thorium & $3.0 \mathrm{E}+03$ & \\
\hline & Protactinium & $1.8 \mathrm{E}+03$ & \\
\hline & Uranium & 3.3E+01 & \\
\hline & Neptunium & $2.5 \mathrm{E}+01$ & \\
\hline & Plutonium & $1.2 \mathrm{E}+03$ & \\
\hline & Americium & $2.0 \mathrm{E}+03$ & \\
\hline Overwatering rate, $\mathrm{m} / \mathrm{yr}$ & Present-day climate & 0.079 & MO0403SPAAEIBM.002 [DIRS 169392] \\
\hline \multicolumn{2}{|l|}{ Volumetric water content } & 0.23 & MO0407SPASRPBM.002 [DIRS 170755] \\
\hline \multicolumn{4}{|c|}{ AIR SUBMODEL } \\
\hline \multicolumn{2}{|c|}{ Mass loading for crops at nominal conditions, $\mathrm{mg} / \mathrm{m}^{3}$} & 0.12 & MO0407SPAINEXI.002 [DIRS 170597] \\
\hline \multicolumn{2}{|c|}{ Mass loading for crops at volcanic conditions, $\mathrm{mg} / \mathrm{m}^{3}$} & 0.24 & MO0407SPAINEXI.002 [DIRS 170597] \\
\hline \multirow{4}{*}{$\begin{array}{l}\text { Mass loading for receptor } \\
\text { environments at nominal } \\
\text { conditions, } \mathrm{mg} / \mathrm{m}^{3}\end{array}$} & Active outdoors & 5.00 & \multirow{4}{*}{ MO0407SPAINEXI.002 [DIRS 170597] } \\
\hline & Inactive outdoors & 0.06 & \\
\hline & Active indoors & 0.10 & \\
\hline & Asleep indoors & 0.03 & \\
\hline \multirow{4}{*}{$\begin{array}{l}\text { Mass loading for ash for } \\
\text { receptor environments, } \\
\mathrm{mg} / \mathrm{m}^{3}\end{array}$} & Active outdoors & 2.50 & \multirow{4}{*}{ MO0407SPAINEXI.002 [DIRS 170597] } \\
\hline & Inactive outdoors & 0.06 & \\
\hline & Active indoors & 0.10 & \\
\hline & Asleep indoors & 0.03 & \\
\hline \multirow{4}{*}{$\begin{array}{l}\text { Enhancement factor at } \\
\text { nominal conditions }\end{array}$} & Active outdoors & 4.0 & \multirow{4}{*}{ MO0407SPASRPBM.002 [DIRS 170755] } \\
\hline & Inactive outdoors & 0.7 & \\
\hline & Active indoors & 0.7 & \\
\hline & Asleep indoors & 0.7 & \\
\hline \multirow{4}{*}{$\begin{array}{l}\text { Enhancement factor for } \\
\text { volcanic scenario }\end{array}$} & Active outdoors & 4.4 & \\
\hline & Inactive outdoors & 0.7 & MOO407SPASRPBM 002 [DIRS 170755] \\
\hline & Active indoors & 0.7 & ] \\
\hline & Asleep indoors & 0.7 & \\
\hline
\end{tabular}


Table 4.1-1. Summary of Input Parameter Values Used in Deterministic Model Runs (Continued)

\begin{tabular}{|c|c|c|c|}
\hline \multicolumn{2}{|c|}{ Parameter Name and Unit } & Value & DTN/Reference \\
\hline \multicolumn{2}{|c|}{ Evaporative cooler water transfer fraction } & 0.5 & $\begin{array}{l}\text { MO0406SPAETPBM.002 [DIRS 170150] } \\
\text { (mean value) }\end{array}$ \\
\hline \multicolumn{2}{|c|}{$\begin{array}{l}\text { Evaporative cooler water use (evaporation) rate, } \\
\text { L/hr }\end{array}$} & 17 & MO0406SPAETPBM.002 [DIRS 170150] \\
\hline \multicolumn{2}{|c|}{ Evaporative cooler air flow rate, $\mathrm{m}^{3} / \mathrm{hr}$} & 8300 & $\begin{array}{l}\text { MO0406SPAETPBM.002 [DIRS 170150] } \\
\text { (median value) }\end{array}$ \\
\hline \multicolumn{2}{|c|}{ Radon release factor, $\left(\mathrm{Bq} / \mathrm{m}^{3}\right) /(\mathrm{Bq} / \mathrm{kg})$} & 0.25 & MO0406SPAETPBM.002 [DIRS 170150] \\
\hline \multirow[b]{2}{*}{ House ventilation rate, $1 / \mathrm{hr}$} & Average & 1.0 & \multirow[b]{2}{*}{ MO0406SPAETPBM.002 [DIRS 170150] } \\
\hline & Evaporative cooler on & $\begin{array}{c}\text { Mean } \\
\text { (calculated by } \\
\text { GoldSim from a } \\
\text { distribution) }\end{array}$ & \\
\hline \multicolumn{2}{|c|}{ Fraction of radon from soil entering the house } & $\begin{array}{c}\text { Mean } \\
\text { (calculated by } \\
\text { GoldSim from a } \\
\text { distribution) }\end{array}$ & MO0406SPAETPBM.002 [DIRS 170150] \\
\hline \multicolumn{2}{|c|}{$\begin{array}{l}\text { Ratio of Rn-222 concentration in air to flux density } \\
\text { from soil, }\left(\mathrm{Bq} \mathrm{m^{-3 }}\right) /\left(\mathrm{Bq} \mathrm{m^{-2 }} \mathrm{s}^{-1}\right)\end{array}$} & 300 & MO0406SPAETPBM.002 [DIRS 170150] \\
\hline \multicolumn{4}{|c|}{ SUBMODEL } \\
\hline \multirow{16}{*}{$\begin{array}{l}\text { Soil-to-plant transfer factor } \\
\text { for leafy vegetables, } \\
\left.\text { (Bq/kg plant)/ (Bq/kg } / g_{\text {soil }}\right)\end{array}$} & Chlorine & $6.4 \mathrm{E}+01$ & \multirow{16}{*}{ MO0406SPAETPBM.002 [DIRS 170150] } \\
\hline & Selenium & 4.6E-02 & \\
\hline & Strontium & $1.7 \mathrm{E}+00$ & \\
\hline & Technetium & $4.6 \mathrm{E}+01$ & \\
\hline & Tin & $3.8 \mathrm{E}-02$ & \\
\hline & lodine & 2.6E-02 & \\
\hline & Cesium & $8.5 \mathrm{E}-02$ & \\
\hline & Lead & 1.5E-02 & \\
\hline & Radium & $6.8 \mathrm{E}-02$ & \\
\hline & Actinium & 4.3E-03 & \\
\hline & Thorium & 4.3E-03 & \\
\hline & Protactinium & $4.6 \mathrm{E}-03$ & \\
\hline & Uranium & 1.1E-02 & \\
\hline & Neptunium & $5.9 \mathrm{E}-02$ & \\
\hline & Plutonium & $2.9 \mathrm{E}-04$ & \\
\hline & Americium & $1.2 \mathrm{E}-03$ & \\
\hline \multirow{12}{*}{$\begin{array}{l}\text { Soil-to-plant transfer factor } \\
\text { for other vegetables, } \\
\text { (Bq/kg } / \mathrm{kg}_{\text {plant }} /\left(\mathrm{Bq} / \mathrm{kg}_{\text {soil }}\right)\end{array}$} & Chlorine & $6.4 \mathrm{E}+01$ & \multirow{12}{*}{ MO0406SPAETPBM.002 [DIRS 170150] } \\
\hline & Selenium & 4.6E-02 & \\
\hline & Strontium & 7.9E-01 & \\
\hline & Technetium & $4.4 \mathrm{E}+00$ & \\
\hline & Tin & $1.5 \mathrm{E}-02$ & \\
\hline & lodine & $3.2 \mathrm{E}-02$ & \\
\hline & Cesium & $5.0 \mathrm{E}-02$ & \\
\hline & Lead & $9.0 \mathrm{E}-03$ & \\
\hline & Radium & $1.2 \mathrm{E}-02$ & \\
\hline & Actinium & 1.1E-03 & \\
\hline & Thorium & 4.4E-04 & \\
\hline & Protactinium & $1.1 \mathrm{E}-03$ & \\
\hline
\end{tabular}


Table 4.1-1. Summary of Input Parameter Values Used in Deterministic Model Runs (Continued)

\begin{tabular}{|c|c|c|c|}
\hline \multicolumn{2}{|c|}{ Parameter Name and Unit } & \multirow{2}{*}{$\begin{array}{c}\text { Value } \\
6.0 \mathrm{E}-03\end{array}$} & DTN/Reference \\
\hline \multirow{4}{*}{ 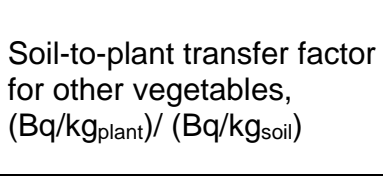 } & Uranium & & \multirow{4}{*}{ MO0406SPAETPBM.002 [DIRS 170150] } \\
\hline & Neptunium & $3.1 \mathrm{E}-02$ & \\
\hline & Plutonium & 1.9E-04 & \\
\hline & Americium & 4.0E-04 & \\
\hline \multirow{16}{*}{$\begin{array}{l}\text { Soil-to-plant transfer factor } \\
\text { for fruit, }\left(\mathrm{Bq} / \mathrm{kg}_{\text {plant }}\right) / \\
\left(\mathrm{Bq} / \mathrm{kg}_{\text {soil }}\right)\end{array}$} & Chlorine & $6.4 \mathrm{E}+01$ & \multirow{16}{*}{ MO0406SPAETPBM.002 [DIRS 170150] } \\
\hline & Selenium & 4.6E-02 & \\
\hline & Strontium & 2.9E-01 & \\
\hline & Technetium & $4.3 E+00$ & \\
\hline & Tin & $1.5 \mathrm{E}-02$ & \\
\hline & lodine & 5.7E-02 & \\
\hline & Cesium & $5.6 \mathrm{E}-02$ & \\
\hline & Lead & $1.2 \mathrm{E}-02$ & \\
\hline & Radium & 7.3E-03 & \\
\hline & Actinium & 8.5E-04 & \\
\hline & Thorium & 2.9E-04 & \\
\hline & Protactinium & 1.1E-03 & \\
\hline & Uranium & 6.3E-03 & \\
\hline & Neptunium & $3.4 \mathrm{E}-02$ & \\
\hline & Plutonium & 1.8E-04 & \\
\hline & Americium & $5.4 \mathrm{E}-04$ & \\
\hline \multirow{16}{*}{$\begin{array}{l}\text { Soil-to-plant transfer factor } \\
\text { for grain }\left(\mathrm{Bq} / \mathrm{kg}_{\text {plant }}\right) / \\
\left(\mathrm{Bq} / \mathrm{kg}_{\text {soil }}\right)\end{array}$} & Chlorine & $2.4 \mathrm{E}+01$ & \multirow{16}{*}{ MO0406SPAETPBM.002 [DIRS 170150] } \\
\hline & Selenium & 2.9E-02 & \\
\hline & Strontium & 1.7E-01 & \\
\hline & Technetium & $1.6 \mathrm{E}+00$ & \\
\hline & Tin & $9.2 \mathrm{E}-03$ & \\
\hline & lodine & $2.5 \mathrm{E}-02$ & \\
\hline & Cesium & 2.0E-02 & \\
\hline & Lead & $5.5 \mathrm{E}-03$ & \\
\hline & Radium & 3.1E-03 & \\
\hline & Actinium & $5.4 \mathrm{E}-04$ & \\
\hline & Thorium & 1.7E-04 & \\
\hline & Protactinium & $9.5 \mathrm{E}-04$ & \\
\hline & Uranium & 1.1E-03 & \\
\hline & Neptunium & 4.4E-03 & \\
\hline & Plutonium & $1.9 \mathrm{E}-05$ & \\
\hline & Americium & $7.5 \mathrm{E}-05$ & \\
\hline \multirow{12}{*}{$\begin{array}{l}\text { Soil-to-plant transfer factor } \\
\text { for forage crops, } \\
\text { (Bq/kg } / \mathrm{kgnt}_{\mathrm{pl}} /\left(\mathrm{Bq} / \mathrm{kg}_{\text {soil }}\right)\end{array}$} & Chlorine & $7.5 \mathrm{E}+01$ & \multirow{12}{*}{ MO0406SPAETPBM.002 [DIRS 170150] } \\
\hline & Selenium & $1.5 \mathrm{E}-01$ & \\
\hline & Strontium & $2.1 E+00$ & \\
\hline & Technetium & $2.7 E+01$ & \\
\hline & Tin & $1.6 \mathrm{E}-01$ & \\
\hline & lodine & 4.0E-02 & \\
\hline & Cesium & 1.3E-01 & \\
\hline & Lead & $1.8 \mathrm{E}-02$ & \\
\hline & Radium & 8.2E-02 & \\
\hline & Actinium & 1.7E-02 & \\
\hline & Thorium & $1.0 \mathrm{E}-02$ & \\
\hline & Protactinium & 1.9E-02 & \\
\hline
\end{tabular}


Table 4.1-1. Summary of Input Parameter Values Used in Deterministic Model Runs (Continued)

\begin{tabular}{|c|c|c|c|}
\hline \multicolumn{2}{|c|}{ Parameter Name and Unit } & \multirow{2}{*}{$\frac{\text { Value }}{1.7 \mathrm{E}-02}$} & DTN/Reference \\
\hline \multirow{4}{*}{$\begin{array}{l}\text { Soil-to-plant transfer factor } \\
\text { for forage crops, } \\
\left(\mathrm{Bq} / \mathrm{kg}_{\text {plant }}\right) /\left(\mathrm{Bq} / \mathrm{kg}_{\text {soil }}\right)\end{array}$} & Uranium & & \multirow{4}{*}{ MO0406SPAETPBM.002 [DIRS 170150] } \\
\hline & Neptunium & $5.8 \mathrm{E}-02$ & \\
\hline & Plutonium & 1.0E-03 & \\
\hline & Americium & 2.1E-03 & \\
\hline \multirow{5}{*}{$\begin{array}{l}\text { Dry-to-wet weight ratio, } \\
\mathrm{kg}_{\mathrm{dry}} / \mathrm{kg}_{\text {wet }}\end{array}$} & Leafy vegetables & 0.070 & \multirow{5}{*}{ MO0403SPAAEIBM.002 [DIRS 169392] } \\
\hline & Other vegetables & 0.103 & \\
\hline & Fruit & 0.120 & \\
\hline & Grain & 0.903 & \\
\hline & Forage & 0.220 & \\
\hline \multirow{5}{*}{ Translocation factor } & Leafy vegetables & 1.0 & \multirow{5}{*}{ MO0406SPAETPBM.002 [DIRS 170150] } \\
\hline & Other vegetables & 0.1 & \\
\hline & Fruit & 0.1 & \\
\hline & Grain & 0.1 & \\
\hline & Forage & 1.0 & \\
\hline \multirow{5}{*}{$\begin{array}{l}\text { Fraction of overhead } \\
\text { irrigation }\end{array}$} & Leafy vegetables & 0.75 & \multirow{5}{*}{ MO0403SPAAEIBM.002 [DIRS 169392] } \\
\hline & Other vegetables & 0.75 & \\
\hline & Fruit & 0.50 & \\
\hline & Grain & 0.90 & \\
\hline & Forage & 0.90 & \\
\hline \multicolumn{2}{|l|}{ Weathering half-life, $d$} & 14 & MO0406SPAETPBM.002 [DIRS 170150] \\
\hline \multirow{5}{*}{$\begin{array}{l}\text { Crop growing time, } \\
\text { present-day climate, d }\end{array}$} & Leafy vegetables & 75 & \multirow{5}{*}{ MO0403SPAAEIBM.002 [DIRS 169392] } \\
\hline & Other vegetables & 80 & \\
\hline & Fruit & 160 & \\
\hline & Grain & 200 & \\
\hline & Forage & 75 & \\
\hline \multirow{5}{*}{ Crop wet yield, $\mathrm{kg} / \mathrm{m}^{2}$} & Leafy vegetables & 3.30 & \multirow{5}{*}{ MO0403SPAAEIBM.002 [DIRS 169392] } \\
\hline & Other vegetables & 4.13 & \\
\hline & Fruit & 2.75 & \\
\hline & Grain & 0.59 & \\
\hline & Forage & 2.14 & \\
\hline \multirow{5}{*}{ Crop dry biomass, $\mathrm{kg} / \mathrm{m}^{2}$} & Leafy vegetables & 0.21 & \multirow{5}{*}{ MO0403SPAAEIBM.002 [DIRS 169392] } \\
\hline & Other vegetables & 0.43 & \\
\hline & Fruit & 0.62 & \\
\hline & Grain & 1.13 & \\
\hline & Forage & 0.48 & \\
\hline \multirow{5}{*}{$\begin{array}{l}\text { Daily average irrigation } \\
\text { rate, present-day climate, } \\
\mathrm{mm} / \mathrm{d}\end{array}$} & Leafy vegetables & 5.41 & \multirow{5}{*}{ MO0403SPAAEIBM.002 [DIRS 169392] } \\
\hline & Other vegetables & 7.71 & \\
\hline & Fruit & 7.41 & \\
\hline & Grain & 4.64 & \\
\hline & Forage & 6.55 & \\
\hline \multirow{5}{*}{$\begin{array}{l}\text { Irrigation amount per } \\
\text { application, present-day } \\
\text { climate, mm }\end{array}$} & Leafy vegetables & 14.7 & \multirow{5}{*}{ MO0403SPAAEIBM.002 [DIRS 169392] } \\
\hline & Other vegetables & 26.0 & \\
\hline & Fruit & 33.9 & \\
\hline & Grain & 56.7 & \\
\hline & Forage & 57.8 & \\
\hline
\end{tabular}


Table 4.1-1. Summary of Input Parameter Values Used in Deterministic Model Runs (Continued)

\begin{tabular}{|c|c|c|c|}
\hline \multicolumn{2}{|c|}{ Parameter Name and Unit } & Value & DTN/Reference \\
\hline \multicolumn{2}{|c|}{ Irrigation intensity, $\mathrm{cm} / \mathrm{hr}$} & 4.3 & MO0403SPAAEIBM.002 [DIRS 169392] \\
\hline \multicolumn{2}{|l|}{ Dry deposition velocity, $\mathrm{m} / \mathrm{s}$} & 0.008 & MO0406SPAETPBM.002 [DIRS 170150] \\
\hline \multicolumn{4}{|c|}{ A NIMAL SUBMODEL } \\
\hline \multirow{16}{*}{$\begin{array}{l}\text { Animal product transfer } \\
\text { coefficients for meat, } \mathrm{d} / \mathrm{kg}\end{array}$} & Chlorine & 4.6E-02 & \multirow{16}{*}{ MO0406SPAETPBM.002 [DIRS 170150] } \\
\hline & Selenium & 8.8E-02 & \\
\hline & Strontium & 1.4E-03 & \\
\hline & Technetium & 1.1E-03 & \\
\hline & Tin & 1.9E-02 & \\
\hline & lodine & 1.0E-02 & \\
\hline & Cesium & 2.4E-02 & \\
\hline & Lead & $6.3 \mathrm{E}-04$ & \\
\hline & Radium & 8.1E-04 & \\
\hline & Actinium & 7.9E-05 & \\
\hline & Thorium & 1.1E-04 & \\
\hline & Protactinium & 6.6E-05 & \\
\hline & Uranium & 4.8E-04 & \\
\hline & Neptunium & 3.4E-04 & \\
\hline & Plutonium & 1.3E-05 & \\
\hline & Americium & 3.4E-05 & \\
\hline \multirow{16}{*}{$\begin{array}{l}\text { Animal product transfer } \\
\text { coefficients for milk, } d / L\end{array}$} & Chlorine & 1.8E-02 & \multirow{16}{*}{ MO0406SPAETPBM.002 [DIRS 170150] } \\
\hline & Selenium & 5.7E-03 & \\
\hline & Strontium & 1.7E-03 & \\
\hline & Technetium & 2.1E-03 & \\
\hline & Tin & 1.1E-03 & \\
\hline & Iodine & $9.1 \mathrm{E}-03$ & \\
\hline & Cesium & 7.7E-03 & \\
\hline & Lead & 1.7E-04 & \\
\hline & Radium & $5.8 \mathrm{E}-04$ & \\
\hline & Actinium & 7.6E-06 & \\
\hline & Thorium & 4.4E-06 & \\
\hline & Protactinium & 4.4E-06 & \\
\hline & Uranium & 4.9E-04 & \\
\hline & Neptunium & 6.3E-06 & \\
\hline & Plutonium & 2.3E-07 & \\
\hline & Americium & 1.6E-06 & \\
\hline \multirow{12}{*}{$\begin{array}{l}\text { Animal product transfer } \\
\text { coefficients for poultry, } \mathrm{d} / \mathrm{kg}\end{array}$} & Chlorine & $3.0 \mathrm{E}-02$ & \multirow{12}{*}{ MO0406SPAETPBM.002 [DIRS 170150] } \\
\hline & Selenium & $5.1 \mathrm{E}+00$ & \\
\hline & Strontium & 3.1E-02 & \\
\hline & Technetium & 6.3E-02 & \\
\hline & Tin & $3.5 E-02$ & \\
\hline & lodine & 5.5E-02 & \\
\hline & Cesium & $2.6 \mathrm{E}+00$ & \\
\hline & Lead & $2.5 \mathrm{E}-02$ & \\
\hline & Radium & 1.7E-02 & \\
\hline & Actinium & 4.0E-03 & \\
\hline & Thorium & 5.9E-03 & \\
\hline & Protactinium & 3.0E-03 & \\
\hline
\end{tabular}


Table 4.1-1. Summary of Input Parameter Values Used in Deterministic Model Runs (Continued)

\begin{tabular}{|c|c|c|c|}
\hline \multicolumn{2}{|c|}{ Parameter Name and Unit } & \multirow{2}{*}{$\frac{\text { Value }}{2.4 \mathrm{E}-01}$} & DTN/Reference \\
\hline \multirow{4}{*}{$\begin{array}{l}\text { Animal product transfer } \\
\text { coefficients for poultry, } \mathrm{d} / \mathrm{kg}\end{array}$} & Uranium & & \multirow{4}{*}{ MO0406SPAETPBM.002 [DIRS 170150] } \\
\hline & Neptunium & 3.6E-03 & \\
\hline & Plutonium & $1.2 \mathrm{E}-03$ & \\
\hline & Americium & $1.8 \mathrm{E}-03$ & \\
\hline \multirow{16}{*}{$\begin{array}{l}\text { Animal product transfer } \\
\text { coefficients for eggs, } \mathrm{d} / \mathrm{kg}\end{array}$} & Chlorine & 4.4E-02 & \multirow{16}{*}{ MO0406SPAETPBM.002 [DIRS 170150] } \\
\hline & Selenium & $7.3 \mathrm{E}+00$ & \\
\hline & Strontium & 2.7E-01 & \\
\hline & Technetium & $2.4 \mathrm{E}+00$ & \\
\hline & Tin & 8.7E-02 & \\
\hline & lodine & $2.6 \mathrm{E}+00$ & \\
\hline & Cesium & 3.5E-01 & \\
\hline & Lead & $5.6 \mathrm{E}-02$ & \\
\hline & Radium & $3.9 E-04$ & \\
\hline & Actinium & 2.9E-03 & \\
\hline & Thorium & 3.5E-03 & \\
\hline & Protactinium & 2.0E-03 & \\
\hline & Uranium & 6.3E-01 & \\
\hline & Neptunium & 3.4E-03 & \\
\hline & Plutonium & 1.7E-03 & \\
\hline & Americium & 4.9E-03 & \\
\hline \multirow{4}{*}{$\begin{array}{l}\text { Animal consumption rate of } \\
\mathrm{feed}, \mathrm{kg} / \mathrm{d}\end{array}$} & Beef cattle & $\begin{array}{c}\text { Mean } \\
\text { (calculated by } \\
\text { GoldSim from a } \\
\text { distribution) }\end{array}$ & \multirow{4}{*}{ MO0406SPAETPBM.002 [DIRS 170150] } \\
\hline & Dairy cow & $\begin{array}{c}\text { Mean } \\
\text { (calculated by } \\
\text { GoldSim from a } \\
\text { distribution) }\end{array}$ & \\
\hline & Poultry & $\begin{array}{l}\text { Mean } \\
\text { (calculated by } \\
\text { GoldSim from a } \\
\text { distribution) }\end{array}$ & \\
\hline & Laying hen & $\begin{array}{c}\text { Mean } \\
\text { (calculated by } \\
\text { GoldSim from a } \\
\text { distribution) }\end{array}$ & \\
\hline \multirow{4}{*}{$\begin{array}{l}\text { Animal consumption rate of } \\
\text { water, L/d }\end{array}$} & Beef cattle & 60 & \multirow{4}{*}{ MO0406SPAETPBM.002 [DIRS 170150] } \\
\hline & Dairy cow & $\begin{array}{c}\text { Mean } \\
\text { (calculated by } \\
\text { GoldSim from a } \\
\text { distribution) } \\
\end{array}$ & \\
\hline & Poultry & 0.5 & \\
\hline & Laying hen & 0.5 & \\
\hline \multirow{2}{*}{$\begin{array}{l}\text { Animal consumption rate of } \\
\text { soil, } \mathrm{kg} / \mathrm{d}\end{array}$} & Beef cattle & $\begin{array}{c}\text { Mean } \\
\text { (calculated by } \\
\text { GoldSim from a } \\
\text { distribution) }\end{array}$ & \multirow{2}{*}{ MO0406SPAETPBM.002 [DIRS 170150] } \\
\hline & Dairy cow & $\begin{array}{c}\text { Mean } \\
\text { (calculated by } \\
\text { GoldSim from a } \\
\text { distribution) }\end{array}$ & \\
\hline
\end{tabular}


Table 4.1-1. Summary of Input Parameter Values Used in Deterministic Model Runs (Continued)

\begin{tabular}{|c|c|c|c|}
\hline \multicolumn{2}{|c|}{ Parameter Name and Unit } & \multirow{3}{*}{$\begin{array}{c}\text { Value } \\
\text { Mean } \\
\text { (calculated by } \\
\text { GoldSim from a } \\
\text { distribution) } \\
\text { Mean } \\
\text { (calculated by } \\
\text { GoldSim from a } \\
\text { distribution) }\end{array}$} & DTN/Reference \\
\hline \multirow{2}{*}{$\begin{array}{l}\text { Animal consumption rate of } \\
\text { soil, } \mathrm{kg} / \mathrm{d}\end{array}$} & Poultry & & \multirow{2}{*}{ MO0406SPAETPBM.002 [DIRS 170150] } \\
\hline & Laying hen & & \\
\hline \multicolumn{4}{|c|}{ SUBMODEL } \\
\hline \multirow{17}{*}{$\begin{array}{l}\text { Bioaccumulation factor, } \\
\mathrm{L} / \mathrm{kg}\end{array}$} & Carbon & $4.6 \mathrm{E}+03$ & \multirow{17}{*}{ MO0406SPAETPBM.002 [DIRS 170150] } \\
\hline & Chlorine & $2.2 \mathrm{E}+02$ & \\
\hline & Selenium & $2.3 E+02$ & \\
\hline & Strontium & $4.6 \mathrm{E}+01$ & \\
\hline & Technetium & $2.0 \mathrm{E}+01$ & \\
\hline & Tin & $2.5 \mathrm{E}+03$ & \\
\hline & lodine & $4.5 \mathrm{E}+01$ & \\
\hline & Cesium & $3.5 \mathrm{E}+03$ & \\
\hline & Lead & $2.9 \mathrm{E}+02$ & \\
\hline & Radium & $6.7 \mathrm{E}+01$ & \\
\hline & Actinium & $2.9 \mathrm{E}+01$ & \\
\hline & Thorium & $1.1 \mathrm{E}+02$ & \\
\hline & Protactinium & $1.2 \mathrm{E}+01$ & \\
\hline & Uranium & $1.4 \mathrm{E}+01$ & \\
\hline & Neptunium & $3.0 \mathrm{E}+01$ & \\
\hline & Plutonium & $4.1 \mathrm{E}+01$ & \\
\hline & Americium & $5.2 \mathrm{E}+01$ & \\
\hline \multirow[b]{2}{*}{$\begin{array}{l}\text { Water concentration } \\
\text { modifying factor, present- } \\
\text { day climate }\end{array}$} & Carbon & 1 & \multirow[b]{2}{*}{ MO0406SPAETPBM.002 [DIRS 170150] } \\
\hline & Other elements & $\begin{array}{c}\text { Mean } \\
\text { (calculated by } \\
\text { GoldSim from a } \\
\text { distribution) }\end{array}$ & \\
\hline \multicolumn{4}{|c|}{ SPECIAL CARBON-14 MODEL } \\
\hline \multicolumn{2}{|l|}{ C-14 emission rate, $1 / \mathrm{yr}$} & 22 & MO0406SPAETPBM.002 [DIRS 170150] \\
\hline \multicolumn{2}{|l|}{ Annual water demand, $\mathrm{m}^{3} / \mathrm{yr}$} & $3,714,450$ & MO0406SPAETPBM.002 [DIRS 170150] \\
\hline \multirow{2}{*}{$\begin{array}{l}\text { Annual average wind } \\
\text { speed, } \mathrm{m} / \mathrm{s}\end{array}$} & Inhalation & $\begin{array}{c}\text { Mean } \\
\text { (calculated by } \\
\text { GoldSim from a } \\
\text { distribution) }\end{array}$ & \multirow{2}{*}{ MO0406SPAETPBM.002 [DIRS 170150] } \\
\hline & Crops & $\begin{array}{c}\text { Mean } \\
\text { (calculated by } \\
\text { GoldSim from a } \\
\text { distribution) }\end{array}$ & \\
\hline \multirow{2}{*}{$\mathrm{C}-14$ mixing height, $\mathrm{m}$} & Inhalation & 2 & \multirow{2}{*}{ MO0406SPAETPBM.002 [DIRS 170150] } \\
\hline & Crops & 1 & \\
\hline \multicolumn{2}{|c|}{ Fraction of air-derived carbon in plants } & 0.98 & MO0406SPAETPBM.002 [DIRS 170150] \\
\hline \multicolumn{2}{|c|}{ Fraction of soil-derived carbon in plants } & 0.02 & MO0406SPAETPBM.002 [DIRS 170150] \\
\hline \multirow{3}{*}{$\begin{array}{l}\text { Fraction of stable carbon in } \\
\text { plants }\end{array}$} & Leafy vegetables & 0.09 & \multirow{3}{*}{ MO0406SPAETPBM.002 [DIRS 170150] } \\
\hline & Other vegetables & 0.09 & \\
\hline & Fruit & 0.09 & \\
\hline
\end{tabular}


Table 4.1-1. Summary of Input Parameter Values Used in Deterministic Model Runs (Continued)

\begin{tabular}{|c|c|c|c|}
\hline \multicolumn{2}{|c|}{ Parameter Name and Unit } & \multirow{2}{*}{$\begin{array}{c}\text { Value } \\
0.40\end{array}$} & DTN/Reference \\
\hline \multirow{2}{*}{$\begin{array}{l}\text { Fraction of stable carbon } \\
\text { in plants }\end{array}$} & Grain & & \multirow{2}{*}{ MO0406SPAETPBM.002 [DIRS 170150] } \\
\hline & Forage & 0.09 & \\
\hline \multicolumn{2}{|c|}{ Fraction of stable carbon in soil } & 0.03 & MO0406SPAETPBM.002 [DIRS 170150] \\
\hline \multicolumn{2}{|c|}{ Concentration of stable carbon in air } & $1.8 \mathrm{E}-04$ & MO0406SPAETPBM.002 [DIRS 170150] \\
\hline \multicolumn{2}{|c|}{ Concentration of stable carbon in water } & $2.0 \mathrm{E}-05$ & MO0406SPAETPBM.002 [DIRS 170150] \\
\hline \multirow{4}{*}{$\begin{array}{l}\text { Fraction of stable carbon } \\
\text { in animal products }\end{array}$} & Meat & 0.24 & \multirow{4}{*}{ MO0406SPAETPBM.002 [DIRS 170150] } \\
\hline & Milk & 0.07 & \\
\hline & Poultry & 0.2 & \\
\hline & Eggs & 0.15 & \\
\hline \multicolumn{4}{|c|}{ EXTER N A L } \\
\hline \multirow{4}{*}{$\begin{array}{l}\text { Population proportion, } \\
\text { groundwater exposure } \\
\text { scenario, \% }\end{array}$} & Outdoor workers & 0.055 & \multirow{8}{*}{ MO0407SPACRBSM.002 [DIRS 170677] } \\
\hline & Indoor workers & GoldSim Calc. & \\
\hline & Commuters & 0.392 & \\
\hline & Non-workers & 0.392 & \\
\hline \multirow{4}{*}{$\begin{array}{l}\text { Population proportion, } \\
\text { volcanic ash exposure } \\
\text { scenario, } \%\end{array}$} & Outdoor workers & 0.055 & \\
\hline & Indoor workers & GoldSim Calc. & \\
\hline & Commuters & 0.125 & \\
\hline & Non-workers & 0.392 & \\
\hline \multirow{5}{*}{$\begin{array}{l}\text { Time spent by outdoor } \\
\text { workers, groundwater } \\
\text { exposure scenario, hr/d }\end{array}$} & Active outdoors & 3.1 & \multirow{30}{*}{ MO0407SPACRBSM.002 [DIRS 170677] } \\
\hline & Inactive outdoors & 4.0 & \\
\hline & Active indoors & 6.6 & \\
\hline & Asleep indoors & 8.3 & \\
\hline & Away & 2.0 & \\
\hline \multirow{5}{*}{$\begin{array}{l}\text { Time spent by outdoor } \\
\text { workers, volcanic ash } \\
\text { exposure scenario, hr/d }\end{array}$} & Active outdoors & 3.1 & \\
\hline & Inactive outdoors & 4.2 & \\
\hline & Active indoors & 6.4 & \\
\hline & Asleep indoors & 8.3 & \\
\hline & Away & 2.0 & \\
\hline \multirow{5}{*}{$\begin{array}{l}\text { Time spent by indoor } \\
\text { workers, groundwater } \\
\text { exposure scenario, hr/d }\end{array}$} & Active outdoors & 0.3 & \\
\hline & Inactive outdoors & 1.3 & \\
\hline & Active indoors & 12.1 & \\
\hline & Asleep indoors & 8.3 & \\
\hline & Away & 2.0 & \\
\hline \multirow{5}{*}{$\begin{array}{l}\text { Time spent by indoor } \\
\text { workers, volcanic ash } \\
\text { exposure scenario, hr/d }\end{array}$} & Active outdoors & 0.3 & \\
\hline & Inactive outdoors & 1.5 & \\
\hline & Active indoors & 11.9 & \\
\hline & Asleep indoors & 8.3 & \\
\hline & Away & 2.0 & \\
\hline \multirow{5}{*}{$\begin{array}{l}\text { Time spent by commuters, } \\
\text { groundwater exposure } \\
\text { scenario, hr/d }\end{array}$} & Active outdoors & 0.3 & \\
\hline & Inactive outdoors & 1.4 & \\
\hline & Active indoors & 6.0 & \\
\hline & Asleep indoors & 8.3 & \\
\hline & Away & 8.0 & \\
\hline \multirow{5}{*}{$\begin{array}{l}\text { Time spent by commuters, } \\
\text { volcanic ash exposure } \\
\text { scenario, } \mathrm{hr} / \mathrm{d}\end{array}$} & Active outdoors & 0.3 & \\
\hline & Inactive outdoors & 2.0 & \\
\hline & Active indoors & 5.1 & \\
\hline & Asleep indoors & 8.3 & \\
\hline & Away & 8.3 & \\
\hline
\end{tabular}


Table 4.1-1. Summary of Input Parameter Values Used in Deterministic Model Runs (Continued)

\begin{tabular}{|c|c|c|c|}
\hline \multicolumn{2}{|c|}{ Parameter Name and Unit } & \multirow{2}{*}{$\begin{array}{c}\text { Value } \\
0.3 \\
\end{array}$} & DTN/Reference \\
\hline \multirow{5}{*}{$\begin{array}{l}\text { Time spent by non- } \\
\text { workers, groundwater } \\
\text { exposure scenario and } \\
\text { volcanic exposure } \\
\text { scenario, hr/d }\end{array}$} & Active outdoors & & \multirow{5}{*}{ MO0407SPACRBSM.002 [DIRS 170677] } \\
\hline & Inactive outdoors & 1.2 & \\
\hline & Active indoors & 12.2 & \\
\hline & Asleep indoors & 8.3 & \\
\hline & Away & 2.0 & \\
\hline \multirow{31}{*}{$\begin{array}{l}\text { Building shielding factor, } \\
\text { continued }\end{array}$} & Carbon-14 & 0.2 & \multirow{31}{*}{ MO0407SPACRBSM.002 [DIRS 170677] } \\
\hline & Clorine-36 & 0.4 & \\
\hline & Selenium-79 & 0.1 & \\
\hline & Strontium-90 & 0.4 & \\
\hline & Technetium-99 & 0.2 & \\
\hline & Tin-126 & 0.4 & \\
\hline & lodine-129 & 0.1 & \\
\hline & Cesium-135 & 0.1 & \\
\hline & Cesium-137 & 0.4 & \\
\hline & Plutonium-242 & 0.1 & \\
\hline & Uranium-238 & 0.4 & \\
\hline & Plutonium-238 & 0.1 & \\
\hline & Uranium-234 & 0.2 & \\
\hline & Thorium-230 & 0.3 & \\
\hline & Radium-226 & 0.4 & \\
\hline & Lead-210 & 0.4 & \\
\hline & Plutonium-240 & 0.1 & \\
\hline & Uranium-236 & 0.1 & \\
\hline & Thorium-232 & 0.2 & \\
\hline & Radium-228 & 0.4 & \\
\hline & Uranium-232 & 0.3 & \\
\hline & Thorium-228 & 0.4 & \\
\hline & Americium-243 & 0.4 & \\
\hline & Plutonium-239 & 0.3 & \\
\hline & Uranium-235 & 0.4 & \\
\hline & Protactinium-231 & 0.4 & \\
\hline & Actinium-227 & 0.4 & \\
\hline & Americium-241 & 0.2 & \\
\hline & Neptinium-237 & 0.4 & \\
\hline & Uranium-233 & 0.4 & \\
\hline & Thorium-229 & 0.4 & \\
\hline \multicolumn{2}{|c|}{$\begin{array}{l}\text { Dose coefficient for exposure to contaminated soil } \\
\left.\text { (infinite depth), (Sv/yr)/(Bq/m }{ }^{3}\right)\end{array}$} & See Table 4.1-4 & MO0407SPACRBSM.002 [DIRS 170677] \\
\hline \multicolumn{2}{|c|}{$\begin{array}{l}\text { Dose coefficient for exposure to contaminated soil } \\
\text { surface, }(\mathrm{Sv} / \mathrm{yr}) /\left(\mathrm{Bq} / \mathrm{m}^{2}\right)\end{array}$} & See Table 4.1-4 & MO0407SPACRBSM.002 [DIRS 170677] \\
\hline \multicolumn{4}{|c|}{ INHALATION SUBMODEL } \\
\hline \multirow{5}{*}{ Breathing rate, $\mathrm{m}^{3} / \mathrm{hr}$} & Active outdoors & 1.57 & \multirow{5}{*}{ MO0407SPACRBSM.002 [DIRS 170677] } \\
\hline & Inactive outdoors & 1.08 & \\
\hline & Active indoors & 1.08 & \\
\hline & Asleep indoors & 0.39 & \\
\hline & Away & 1.08 & \\
\hline \multicolumn{2}{|c|}{ Dose conversion factor for inhalation, Sv/Bq } & See Table 4.1-3 & MO0407SPACRBSM.002 [DIRS 170677] \\
\hline \multicolumn{2}{|c|}{ Fraction of houses with evaporative coolers } & 0.738 & MO0407SPACRBSM.002 [DIRS 170677] \\
\hline
\end{tabular}


Table 4.1-1. Summary of Input Parameter Values Used in Deterministic Model Runs (Continued)

\begin{tabular}{|c|c|c|c|}
\hline \multicolumn{2}{|c|}{ Parameter Name and Unit } & Value & DTN/Reference \\
\hline \multicolumn{2}{|c|}{ Evaporative cooler use factor, present-day climate } & $\begin{array}{c}\text { Mean } \\
\text { (calculated in } \\
\text { GoldSim) }\end{array}$ & MO0407SPACRBSM.002 [DIRS 170677] \\
\hline \multirow{2}{*}{$\begin{array}{l}\text { Equilibrium factor for } \\
\text { Radon-222 decay products }\end{array}$} & Outdoors & 0.6 & \multirow{2}{*}{ MO0406SPAETPBM.002 [DIRS 170150] } \\
\hline & Indoors & 0.4 & \\
\hline \multicolumn{2}{|c|}{$\begin{array}{l}\text { Dose coefficient for Radon-222 decay products, } \\
\text { Sv/Bq }\end{array}$} & 1.33E-8 & MO0407SPACRBSM.002 [DIRS 170677] \\
\hline \multicolumn{4}{|c|}{ INGESTION SUBMODEL } \\
\hline \multicolumn{2}{|c|}{ Consumption rate of water, L/d } & 2.0 & MO0407SPACRBSM.002 [DIRS 170677] \\
\hline \multirow{9}{*}{$\begin{array}{l}\text { Consumption rate of locally } \\
\text { produced food, } \mathrm{kg} / \mathrm{yr}\end{array}$} & Leafy vegetables & 3.78 & \multirow{9}{*}{ MO0407SPACRBSM.002 [DIRS 170677] } \\
\hline & Other vegetables & 4.73 & \\
\hline & Fruit & 12.68 & \\
\hline & Grain & 0.23 & \\
\hline & Meat & 2.85 & \\
\hline & Milk & 4.66 & \\
\hline & Poultry & 0.42 & \\
\hline & Eggs & 5.30 & \\
\hline & Fish & 0.23 & \\
\hline \multicolumn{2}{|c|}{ Inadvertent soil ingestion rate, $\mathrm{mg} / \mathrm{d}$} & 100 & MO0407SPACRBSM.002 [DIRS 170677] \\
\hline \multicolumn{2}{|c|}{ Dose conversion factor for ingestion, Sv/Bq } & See Table 4.1-3 & MO0407SPACRBSM.002 [DIRS 170677] \\
\hline
\end{tabular}


Table 4.1-2. Primary Radionuclides and Their Decay Products Included in the Biosphere Model

\begin{tabular}{|c|c|c|c|}
\hline Primary Radionuclide & $\begin{array}{c}\text { Short-lived Decay } \\
\text { Product }\end{array}$ & Branching Fraction, \% & Half-life \\
\hline Carbon-14 & & 100 & $5.730 \mathrm{E}+3 \mathrm{yr}$ \\
\hline Chlorine-36 & & 100 & $3.01 \mathrm{E}+05 \mathrm{yr}$ \\
\hline Selenium-79 & & 100 & $6.50 \mathrm{E}+04 \mathrm{yr}$ \\
\hline \multirow[t]{2}{*}{ Strontium-90 } & & 100 & $2.912 \mathrm{E}+01 \mathrm{yr}$ \\
\hline & Yttrium-90 & 100 & $6.40 \mathrm{E}+01 \mathrm{hr}$ \\
\hline Technetium-99 & & 100 & $2.13 \mathrm{E}+05 \mathrm{yr}$ \\
\hline \multirow[t]{3}{*}{ Tin-126 } & & 100 & $1.0 \mathrm{E}+05 \mathrm{yr}$ \\
\hline & Antimony-126m & 100 & $1.90 \mathrm{E}+01 \mathrm{~min}$ \\
\hline & Antimony-126 & 14 & $1.24 \mathrm{E}+01 \mathrm{~d}$ \\
\hline lodine-129 & & 100 & $1.57 \mathrm{E}+07 \mathrm{yr}$ \\
\hline Cesium-135 & & 100 & $2.3 \mathrm{E}+06 \mathrm{yr}$ \\
\hline \multirow[t]{2}{*}{ Cesium-137 } & & 100 & $3.00 \mathrm{E}+01 \mathrm{yr}$ \\
\hline & Barium-137m & 94.60 & $2.552 \mathrm{E}+00 \mathrm{~min}$ \\
\hline \multicolumn{4}{|c|}{ Thorium Series $(4 n)$} \\
\hline Plutonium-240 & & 100 & $6.537 \mathrm{E}+03 \mathrm{yr}$ \\
\hline Uranium-236 & & 100 & $2.3415 \mathrm{E}+07 \mathrm{yr}$ \\
\hline Thorium-232 & & 100 & $1.405 \mathrm{E}+10 \mathrm{yr}$ \\
\hline \multirow[t]{2}{*}{ Radium-228 } & & 100 & $5.75 \mathrm{E}+00 \mathrm{yr}$ \\
\hline & Actinium-228 & 100 & $6.13 \mathrm{E}+00 \mathrm{hr}$ \\
\hline Uranium-232 & & 100 & $7.2 \mathrm{E}+01 \mathrm{yr}$ \\
\hline \multirow[t]{8}{*}{ Thorium-228 } & & 100 & $1.9131 \mathrm{E}+00 \mathrm{yr}$ \\
\hline & Radium-224 & 100 & $3.66 \mathrm{E}+00 \mathrm{~d}$ \\
\hline & Radon-220 & 100 & $5.56 \mathrm{E}+01 \mathrm{~s}$ \\
\hline & Polonium-216 & 100 & $1.5 \mathrm{E}-01 \mathrm{~s}$ \\
\hline & Lead-212 & 100 & $1.064 \mathrm{E}+01 \mathrm{hr}$ \\
\hline & Bismuth-212 & 100 & $6.055 \mathrm{E}+01 \mathrm{mir}$ \\
\hline & Polonium-212 & 64.07 & $3.05 \mathrm{E}-07 \mathrm{~s}$ \\
\hline & Thallium-208 & 35.93 & $3.07 \mathrm{E}+00 \mathrm{~min}$ \\
\hline \multicolumn{4}{|c|}{ Neptunium Series $(4 n+1)$} \\
\hline Americium-241 & & 100 & $4.322 \mathrm{E}+02 \mathrm{yr}$ \\
\hline \multirow[t]{2}{*}{ Neptunium-237 } & & 100 & $2.14 \mathrm{E}+06 \mathrm{yr}$ \\
\hline & Protactinium-233 & 100 & $2.70 \mathrm{E}+01 \mathrm{~d}$ \\
\hline Uranium-233 & & 100 & $1.585 \mathrm{E}+05 \mathrm{yr}$ \\
\hline \multirow[t]{9}{*}{ Thorium-229 } & & 100 & $7.340 \mathrm{E}+03 \mathrm{yr}$ \\
\hline & Radium-225 & 100 & $1.48 \mathrm{E}+01 \mathrm{~d}$ \\
\hline & Actinium-225 & 100 & $1.00 E+01 d$ \\
\hline & Francium-221 & 100 & $4.8 \mathrm{E}+00 \mathrm{~min}$ \\
\hline & Astatine-217 & 100 & 3.23E-02 s \\
\hline & Bismuth-213 & 100 & $4.565 \mathrm{E}+01 \mathrm{~min}$ \\
\hline & Polonium-213 & 97.84 & $4.2 \mathrm{E}-06 \mathrm{~s}$ \\
\hline & Thallium-209 & 2.16 & $2.20 \mathrm{E}+00 \mathrm{~min}$ \\
\hline & Lead-209 & 100 & $3.253 \mathrm{E}+00 \mathrm{hr}$ \\
\hline
\end{tabular}


Table 4.1-2. Primary Radionuclides and Their Decay Products Included in the Biosphere Model (Continued)

\begin{tabular}{|c|c|c|c|}
\hline Primary Radionuclide & $\begin{array}{c}\text { Short-lived Decay } \\
\text { Product }\end{array}$ & Branching Fraction, \% & Half-life \\
\hline \multicolumn{4}{|c|}{ Uranium Series $(4 n+2)$} \\
\hline Plutonium-242 & & 100 & $3.763 \mathrm{E}+05 \mathrm{yr}$ \\
\hline \multirow[t]{4}{*}{ Uranium-238 } & & 100 & $4.468 \mathrm{E}+09 \mathrm{yr}$ \\
\hline & Thorium-234 & 100 & $2.410 E+01 d$ \\
\hline & Protactinium-234m & 99.80 & $1.17 \mathrm{E}+00 \mathrm{~min}$ \\
\hline & Protactinium-234 & 0.33 & $6.70 \mathrm{E}+00 \mathrm{hr}$ \\
\hline Plutonium-238 & & 100 & $8.774 \mathrm{E}+01 \mathrm{yr}$ \\
\hline Uranium-234 & & 100 & $2.445 \mathrm{E}+05 \mathrm{yr}$ \\
\hline Thorium-230 & & 100 & $7.7 \mathrm{E}+04 \mathrm{yr}$ \\
\hline \multirow[t]{8}{*}{ Radium-226 } & & 100 & $1.600 \mathrm{E}+03 \mathrm{yr}$ \\
\hline & Radon-222 & 100 & $3.8235 E+00 d$ \\
\hline & Polonium-218 & 100 & $3.05 \mathrm{E}+00 \mathrm{~min}$ \\
\hline & Lead-214 & 99.98 & $2.68 \mathrm{E}+01 \mathrm{~min}$ \\
\hline & Astatine-218 & 0.02 & 2.E+00 s \\
\hline & Bismuth-214 & 100 & $1.99 \mathrm{E}+01 \mathrm{~min}$ \\
\hline & Polonium-214 & 99.98 & $1.643 \mathrm{E}-04 \mathrm{~s}$ \\
\hline & Thallium-210 & 0.02 & $1.3 \mathrm{E}+00 \min ^{\mathrm{b}}$ \\
\hline \multirow[t]{3}{*}{ Lead-210 } & & 100 & $2.23 \mathrm{E}+01 \mathrm{yr}$ \\
\hline & Bismuth-210 & 100 & $5.012 E+00 d$ \\
\hline & Polonium-210 & 100 & $1.3838 E+02 d$ \\
\hline \multicolumn{4}{|c|}{ Actinium Series $(4 n+3)$} \\
\hline \multirow[t]{2}{*}{ Americium-243 } & & 100 & $7.380 \mathrm{E}+03 \mathrm{yr}$ \\
\hline & Neptunium-239 & 100 & $2.355 E+00 d$ \\
\hline Plutonium-239 & & 100 & $2.4065 \mathrm{E}+04 \mathrm{yr}$ \\
\hline \multirow[t]{2}{*}{ Uranium-235 } & & 100 & $7.038 \mathrm{E}+08 \mathrm{yr}$ \\
\hline & Thorium-231 & 100 & $2.552 \mathrm{E}+01 \mathrm{hr}$ \\
\hline Protactinium-231 & & 100 & $3.276 \mathrm{E}+04 \mathrm{yr}$ \\
\hline \multirow[t]{10}{*}{ Actinium-227 } & & 100 & $2.1773 \mathrm{E}+01 \mathrm{yr}$ \\
\hline & Thorium-227 & 98.62 & $1.8718 \mathrm{E}+01 \mathrm{~d}$ \\
\hline & Francium-223 & 1.38 & $2.18 \mathrm{E}+01 \mathrm{~min}$ \\
\hline & Radium-223 & 100 & $1.1434 \mathrm{E}+01 \mathrm{~d}$ \\
\hline & Radon-219 & 100 & $3.96 \mathrm{E}+00 \mathrm{~s}$ \\
\hline & Polonium-215 & 100 & $1.78 \mathrm{E}-03 \mathrm{~s}$ \\
\hline & Lead-211 & 100 & $3.61 \mathrm{E}+01 \mathrm{~min}$ \\
\hline & Bismuth-211 & 100 & $2.14 \mathrm{E}+00 \mathrm{~min}$ \\
\hline & Thallium-207 & 99.72 & $4.77 \mathrm{E}+00 \mathrm{~min}$ \\
\hline & Polonium-211 & 0.28 & $5.16 \mathrm{E}-01 \mathrm{~s}$ \\
\hline
\end{tabular}

Source: DTN: MO0407SPACRBSM.002 [DIRS 170677].

NOTE: Short-lived decay products of primary radionuclides are assumed to be in secular equilibrium with their parent. 
Table 4.1-3. Dose Conversion Factors for Inhalation and Ingestion of Radionuclides of Interest

\begin{tabular}{|c|c|c|c|}
\hline \multirow[b]{2}{*}{ Primary Radionuclide } & \multirow{2}{*}{$\begin{array}{c}\text { Short-lived Decay } \\
\text { Product }\end{array}$} & \multicolumn{2}{|c|}{ Dose Conversion Factors (Sv/Bq) } \\
\hline & & Inhalation & Ingestion \\
\hline Carbon-14 (as $\left.\mathrm{CO}_{2}\right)$ & & $6.36 \mathrm{E}-12$ & $5.64 \mathrm{E}-10$ \\
\hline Chlorine-36 & & 5.93E-09 & 8.18E-10 \\
\hline Selenium-79 & & 2.66E-09 & 2.35E-09 \\
\hline \multirow[t]{2}{*}{ Strontium-90 } & & $6.47 \mathrm{E}-08$ & 3.85E-08 \\
\hline & Yttrium-90 & 2.28E-09 & 2.91E-09 \\
\hline Technetium-99 & & 2.25E-09 & 3.95E-10 \\
\hline \multirow[t]{3}{*}{ Tin-126 } & & 2.69E-08 & 5.27E-09 \\
\hline & Antimony-126m & 9.17E-12 & 2.54E-11 \\
\hline & Antimony-126 & 3.17E-09 & 2.89E-09 \\
\hline lodine-129 & & 4.69E-08 & $7.46 \mathrm{E}-08$ \\
\hline Cesium-135 & & 1.23E-09 & 1.91E-09 \\
\hline \multirow[t]{2}{*}{ Cesium-137 } & & 8.63E-09 & 1.35E-08 \\
\hline & Barium-137m & - & - \\
\hline \multicolumn{4}{|c|}{ Thorium Series $(4 n)$} \\
\hline Plutonium-240 & & 1.16E-04 & 9.56E-07 \\
\hline Uranium-236 & & 3.39E-05 & 7.26E-08 \\
\hline Thorium-232 & & 4.43E-04 & 7.38E-07 \\
\hline \multirow[t]{2}{*}{ Radium-228 } & & $1.29 \mathrm{E}-06$ & 3.88E-07 \\
\hline & Actinium-228 & 8.33E-08 & $5.85 \mathrm{E}-10$ \\
\hline Uranium-232 & & $1.78 \mathrm{E}-04$ & 3.54E-07 \\
\hline \multirow[t]{8}{*}{ Thorium-228 } & & $9.23 \mathrm{E}-05$ & 1.07E-07 \\
\hline & Radium-224 & 8.53E-07 & 9.89E-08 \\
\hline & Radon-220 & - & - \\
\hline & Polonium-216 & - & - \\
\hline & Lead-212 & 4.56E-08 & 1.23E-08 \\
\hline & Bismuth-212 & 5.83E-09 & 2.87E-10 \\
\hline & Polonium-212 & - & - \\
\hline & Thallium-208 & - & - \\
\hline \multicolumn{4}{|c|}{ Neptunium Series $(4 n+1)$} \\
\hline Americium-241 & & 1.20E-04 & 9.84E-07 \\
\hline \multirow[t]{2}{*}{ Neptunium-237 } & & 1.46E-04 & 1.20E-06 \\
\hline & Protactinium-233 & 2.58E-09 & $9.81 \mathrm{E}-10$ \\
\hline Uranium-233 & & 3.66E-05 & 7.81E-08 \\
\hline \multirow[t]{9}{*}{ Thorium-229 } & & $5.80 \mathrm{E}-04$ & 9.54E-07 \\
\hline & Radium-225 & 2.10E-06 & 1.04E-07 \\
\hline & Actinium-225 & 2.92E-06 & $3.00 \mathrm{E}-08$ \\
\hline & Francium-221 & - & - \\
\hline & Astatine-217 & - & - \\
\hline & Bismuth-213 & 4.63E-09 & $1.95 \mathrm{E}-10$ \\
\hline & Polonium-213 & - & - \\
\hline & Thallium-209 & - & - \\
\hline & Lead-209 & $2.56 \mathrm{E}-11$ & $5.75 \mathrm{E}-11$ \\
\hline
\end{tabular}


Table 4.1-3. Dose Conversion Factors for Inhalation and Ingestion of Radionuclides of Interest (Continued)

\begin{tabular}{|c|c|c|c|}
\hline \multirow[b]{2}{*}{ Primary Radionuclide } & \multirow{2}{*}{$\begin{array}{c}\text { Short-lived Decay } \\
\text { Product }\end{array}$} & \multicolumn{2}{|c|}{ Dose Conversion Factors (Sv/Bq) } \\
\hline & & Inhalation & Ingestion \\
\hline \multicolumn{4}{|c|}{ Uranium Series $(4 n+2)$} \\
\hline Plutonium-242 & & 1.11E-04 & 9.08E-07 \\
\hline \multirow[t]{4}{*}{ Uranium-238 } & & 3.20E-05 & $6.88 \mathrm{E}-08$ \\
\hline & Thorium-234 & 9.47E-09 & 3.69E-09 \\
\hline & Protactinium-234m & - & - \\
\hline & Protactinium-234 & $2.20 \mathrm{E}-10$ & $5.84 \mathrm{E}-10$ \\
\hline Plutonium-238 & & 1.06E-04 & 8.65E-07 \\
\hline Uranium-234 & & 3.58E-05 & 7.66E-08 \\
\hline Thorium-230 & & 8.80E-05 & $1.48 \mathrm{E}-07$ \\
\hline \multirow[t]{8}{*}{ Radium-226 } & & 2.32E-06 & 3.58E-07 \\
\hline & Radon-222 & - & - \\
\hline & Polonium-218 & - & - \\
\hline & Lead-214 & 2.11E-09 & $1.69 \mathrm{E}-10$ \\
\hline & Astatine-218 & - & - \\
\hline & Bismuth-214 & 1.78E-09 & 7.64E-11 \\
\hline & Polonium-214 & - & - \\
\hline & Thallium-210 & - & - \\
\hline \multirow[t]{3}{*}{ Lead-210 } & & 3.67E-06 & $1.45 \mathrm{E}-06$ \\
\hline & Bismuth-210 & 5.29E-08 & 1.73E-09 \\
\hline & Polonium-210 & $2.54 \mathrm{E}-06$ & $5.14 \mathrm{E}-07$ \\
\hline \multicolumn{4}{|c|}{ Actinium Series $(4 n+3)$} \\
\hline \multirow[t]{2}{*}{ Americium-243 } & & 1.19E-04 & 9.79E-07 \\
\hline & Neptunium-239 & $6.78 \mathrm{E}-10$ & 8.82E-10 \\
\hline Plutonium-239 & & 1.16E-04 & 9.56E-07 \\
\hline \multirow[t]{2}{*}{ Uranium-235 } & & 3.32E-05 & 7.19E-08 \\
\hline & Thorium-231 & 2.37E-10 & $3.65 E-10$ \\
\hline Protactinium-231 & & 3.47E-04 & 2.86E-06 \\
\hline \multirow[t]{10}{*}{ Actinium-227 } & & $1.81 \mathrm{E}-03$ & 3.80E-06 \\
\hline & Thorium-227 & 4.37E-06 & 1.03E-08 \\
\hline & Francium-223 & 1.68E-09 & 2.33E-09 \\
\hline & Radium-223 & 2.12E-06 & 1.78E-07 \\
\hline & Radon-219 & - & - \\
\hline & Polonium-215 & - & - \\
\hline & Lead-211 & 2.35E-09 & $1.42 \mathrm{E}-10$ \\
\hline & Bismuth-211 & - & - \\
\hline & Thallium-207 & - & - \\
\hline & Polonium-211 & - & - \\
\hline
\end{tabular}

Source: DTN: MO0407SPACRBSM.002 [DIRS 170677].

NOTES: $1 \mathrm{SV}=100 \mathrm{rem}$

$$
1 \mathrm{Ci}=3.7 \times 10^{10} \mathrm{~Bq}
$$


Table 4.1-4. Dose Coefficients for Exposure to Contaminated Soil for Radionuclides of Interest

\begin{tabular}{|c|c|c|c|}
\hline Primary Radionuclide & Short-lived Decay Product & $\begin{array}{c}\text { Dose Coefficient } \\
\text { Infinite Depth } \\
\text { Svls per Bq/m } \\
\end{array}$ & $\begin{array}{l}\text { Dose Coefficient } \\
\text { Ground Surface } \\
\text { Svls per Bq/m² }\end{array}$ \\
\hline Carbon-14 & & 7.20E-23 & $1.61 \mathrm{E}-20$ \\
\hline Chlorine-36 & & $1.28 \mathrm{E}-20$ & $6.73 \mathrm{E}-19$ \\
\hline Selenium-79 & & 9.96E-23 & 2.07E-20 \\
\hline \multirow[t]{2}{*}{ Strontium-90 } & & 3.77E-21 & 2.84E-19 \\
\hline & Yttrium-90 & $1.28 \mathrm{E}-19$ & $5.32 \mathrm{E}-18$ \\
\hline Technetium-99 & & $6.72 \mathrm{E}-22$ & $7.80 \mathrm{E}-20$ \\
\hline \multirow[t]{3}{*}{ Tin-126 } & & 7.89E-19 & $5.47 \mathrm{E}-17$ \\
\hline & Antimony-126m & $4.98 \mathrm{E}-17$ & $1.52 \mathrm{E}-15$ \\
\hline & Antimony-126 & $9.16 \mathrm{E}-17$ & 2.78E-15 \\
\hline Iodine-129 & & $6.93 E-20$ & $2.58 \mathrm{E}-17$ \\
\hline Cesium-135 & & 2.05E-22 & 3.33E-20 \\
\hline \multirow[t]{2}{*}{ Cesium-137 } & & 4.02E-21 & 2.85E-19 \\
\hline & Barium-137m & 1.93E-17 & $5.86 \mathrm{E}-16$ \\
\hline \multicolumn{4}{|c|}{ Thorium Series $(4 n)$} \\
\hline Plutonium-240 & & 7.85E-22 & 8.03E-19 \\
\hline Uranium-236 & & 1.15E-21 & $6.50 \mathrm{E}-19$ \\
\hline Thorium-232 & & 2.79E-21 & $5.51 \mathrm{E}-19$ \\
\hline \multirow[t]{2}{*}{ Radium-228 } & & $0.00 \mathrm{E}+00$ & $0.00 \mathrm{E}+00$ \\
\hline & Actinium-228 & $3.20 \mathrm{E}-17$ & $9.28 \mathrm{E}-16$ \\
\hline Uranium-232 & & 4.83E-21 & $1.01 \mathrm{E}-18$ \\
\hline \multirow[t]{8}{*}{ Thorium-228 } & & $4.25 \mathrm{E}-20$ & $2.35 \mathrm{E}-18$ \\
\hline & Radium-224 & 2.74E-19 & 9.57E-18 \\
\hline & Radon-220 & 1.23E-20 & 3.81E-19 \\
\hline & Polonium-216 & $5.58 \mathrm{E}-22$ & $1.65 \mathrm{E}-20$ \\
\hline & Lead-212 & $3.77 \mathrm{E}-18$ & 1.43E-16 \\
\hline & Bismuth-212 & $6.27 \mathrm{E}-18$ & 1.79E-16 \\
\hline & Polonium-212 & $0.00 \mathrm{E}+00$ & $0.00 \mathrm{E}+00$ \\
\hline & Thallium-208 & 1.23E-16 & $2.98 \mathrm{E}-15$ \\
\hline \multicolumn{4}{|c|}{ Neptunium Series $(4 n+1)$} \\
\hline Americium-241 & & 2.34E-19 & $2.75 \mathrm{E}-17$ \\
\hline \multirow[t]{2}{*}{ Neptunium-237 } & & 4.17E-19 & $2.87 \mathrm{E}-17$ \\
\hline & Protactinium-233 & $5.46 \mathrm{E}-18$ & $1.95 \mathrm{E}-16$ \\
\hline Uranium-233 & & 7.48E-21 & 7.16E-19 \\
\hline \multirow[t]{9}{*}{ Thorium-229 } & & $1.72 \mathrm{E}-18$ & 8.54E-17 \\
\hline & Radium-225 & $5.90 \mathrm{E}-20$ & 1.33E-17 \\
\hline & Actinium-225 & 3.41E-19 & $1.58 \mathrm{E}-17$ \\
\hline & Francium-221 & 8.22E-19 & $2.98 \mathrm{E}-17$ \\
\hline & Astatine-217 & 9.49E-21 & 3.03E-19 \\
\hline & Bismuth-213 & 4.10E-18 & $1.32 \mathrm{E}-16$ \\
\hline & Polonium-213 & $0.00 \mathrm{E}+00$ & $0.00 \mathrm{E}+00$ \\
\hline & Thallium-209 & $6.92 \mathrm{E}-17$ & 3.01E-19 \\
\hline & Lead-209 & 4.14E-21 & $1.90 \mathrm{E}-15$ \\
\hline
\end{tabular}


Table 4.1-4. Dose Coefficients for Exposure to Contaminated Soil for Radionuclides of Interest (Continued)

\begin{tabular}{|c|c|c|c|}
\hline Primary Radionuclide & Short-lived Decay Product & $\begin{array}{l}\text { Dose Coefficient } \\
\text { Infinite Depth } \\
\text { Svls per Bq// }\end{array}$ & $\begin{array}{l}\text { Dose Coefficient } \\
\text { Ground Surface } \\
\text { Svls per } \mathrm{Bq} / \mathrm{m}^{2}\end{array}$ \\
\hline \multicolumn{4}{|c|}{ Uranium Series $(4 n+2)$} \\
\hline Plutonium-242 & & $6.85 \mathrm{E}-22$ & $6.67 \mathrm{E}-19$ \\
\hline \multirow[t]{4}{*}{ Uranium-238 } & & $5.52 E-22$ & 5.51E-19 \\
\hline & Thorium-234 & 1.29E-19 & 8.32E-18 \\
\hline & Protactinium-234m & 4.80E-19 & 1.53E-17 \\
\hline & Protactinium-234 & $6.18 \mathrm{E}-17$ & $1.84 \mathrm{E}-15$ \\
\hline Plutonium-238 & & $8.10 \mathrm{E}-22$ & 8.38E-19 \\
\hline Uranium-234 & & 2.15E-21 & 7.48E-19 \\
\hline Thorium-230 & & $6.47 \mathrm{E}-21$ & 7.50E-19 \\
\hline \multirow[t]{8}{*}{ Radium-226 } & & $1.70 \mathrm{E}-19$ & $6.44 \mathrm{E}-18$ \\
\hline & Radon-222 & $1.26 \mathrm{E}-20$ & 3.95E-19 \\
\hline & Polonium-218 & $3.02 \mathrm{E}-22$ & $8.88 \mathrm{E}-21$ \\
\hline & Lead-214 & $7.18 \mathrm{E}-18$ & $2.44 \mathrm{E}-16$ \\
\hline & Astatine-218 & $3.13 E-20$ & $4.18 \mathrm{E}-18$ \\
\hline & Bismuth-214 & $5.25 \mathrm{E}-17$ & $1.41 \mathrm{E}-15$ \\
\hline & Polonium-214 & $2.75 E-21$ & 8.13E-20 \\
\hline & Thallium-210 & - & - \\
\hline \multirow[t]{3}{*}{ Lead-210 } & & $1.31 E-20$ & $2.48 \mathrm{E}-18$ \\
\hline & Bismuth-210 & 1.93E-20 & 1.05E-18 \\
\hline & Polonium-210 & 2.80E-22 & $8.29 \mathrm{E}-21$ \\
\hline \multicolumn{4}{|c|}{ Actinium Series $(4 n+3)$} \\
\hline \multirow[t]{2}{*}{ Americium-243 } & & 7.60E-19 & $5.35 \mathrm{E}-17$ \\
\hline & Neptunium-239 & 4.03E-18 & 1.63E-16 \\
\hline Plutonium-239 & & $1.58 \mathrm{E}-21$ & 3.67E-19 \\
\hline \multirow[t]{2}{*}{ Uranium-235 } & & $3.86 \mathrm{E}-18$ & $1.48 \mathrm{E}-16$ \\
\hline & Thorium-231 & 1.95E-19 & 1.85E-17 \\
\hline Protactinium-231 & & $1.02 \mathrm{E}-18$ & 4.07E-17 \\
\hline \multirow[t]{10}{*}{ Actinium-227 } & & 2.65E-21 & 1.57E-19 \\
\hline & Thorium-227 & $2.79 E-18$ & 1.04E-16 \\
\hline & Francium-223 & $1.06 \mathrm{E}-18$ & $5.65 \mathrm{E}-17$ \\
\hline & Radium-223 & 3.23E-18 & $1.28 \mathrm{E}-16$ \\
\hline & Radon-219 & $1.65 \mathrm{E}-18$ & $5.49 \mathrm{E}-17$ \\
\hline & Polonium-215 & $5.44 \mathrm{E}-21$ & 1.74E-19 \\
\hline & Lead-211 & 1.64E-18 & $5.08 \mathrm{E}-17$ \\
\hline & Bismuth-211 & 1.37E-18 & $4.58 \mathrm{E}-17$ \\
\hline & Thallium-207 & 1.06E-19 & $3.76 \mathrm{E}-18$ \\
\hline & Polonium-211 & $2.55 E-19$ & 7.61E-18 \\
\hline
\end{tabular}

Source: DTN: MO0407SPACRBSM.002 [DIRS 170677]. 


\subsection{CRITERIA}

The general requirements to be satisfied by the TSPA are stated in 10 CFR 63.114 [DIRS 156605]. Technical requirements to be satisfied by the TSPA are identified in the Yucca Mountain Project Requirements Document (Canori and Leitner 2003 [DIRS 166275]). The acceptance criteria that will be used by the U.S. Nuclear Regulatory Commission (NRC) to determine whether the technical requirements have been met are identified in the Yucca Mountain Review Plan, Final Report (YMRP) (NRC 2003 [DIRS 163274]). The pertinent requirements and criteria for this report are summarized in Table 4.2-1.

Table 4.2-1. Applicable Project Requirements and Acceptance Criteria

\begin{tabular}{|c|c|c|c|}
\hline $\begin{array}{c}\text { Requirement } \\
\text { Number }^{\mathrm{a}}\end{array}$ & Requirement Title $^{\mathrm{a}}$ & 10 CFR 63 Link & $\begin{array}{l}\text { YMRP Acceptance } \\
\text { Criteria }^{\text {b }} \\
\end{array}$ \\
\hline PRD -002/T-015 & Requirements for Performance Assessment & $\begin{array}{l}10 \text { CFR } 63.114(\mathrm{a}) \text { to } \\
(\mathrm{c}) \text { and }(\mathrm{e}) \text { to }(\mathrm{g})\end{array}$ & \multirow{3}{*}{$\begin{array}{l}\text { 2.2.1.3.14 } \\
\text { Criteria } 1 \text { to } 3\end{array}$} \\
\hline PRD-002/T-026 & $\begin{array}{l}\text { Required Characteristics of the Reference } \\
\text { Biosphere }\end{array}$ & 10 CFR 63.305 & \\
\hline PRD-002/T-028 & $\begin{array}{l}\text { Required Characteristics of the Reasonably } \\
\text { Maximally Exposed Individual }\end{array}$ & 10 CFR 63.312 & \\
\hline PRD -002/T-014 & $\begin{array}{l}\text { Performance Objectives for the Geologic } \\
\text { Repository After Permanent Closure }\end{array}$ & 10 CFR 63.113 (b) & \multirow{3}{*}{$\begin{array}{l}2.2 .1 .4 .1 \\
\text { Criterion } 2\end{array}$} \\
\hline PRD -002/T-015 & Requirements for Performance Assessment & 10 CFR 63.114 & \\
\hline PRD-002/T-028 & $\begin{array}{l}\text { Required Characteristics of the Reasonably } \\
\text { Maximally Exposed Individual }\end{array}$ & 10 CFR 63.312 & \\
\hline
\end{tabular}

a from Canori and Leitner 2003 [DIRS 166275], Table 2-3.

b from NRC 2003 [DIRS 163274].

In addition to the requirements listed in Table 4.2-1, definition of terms in 10 CFR 63.2 and description of concepts in 10 CFR 63.102 [DIRS 156605] that are relevant to biosphere modeling are also applicable to this analysis.

The acceptance criteria identified in Sections 2.2.1.3.13, 2.2.1.3.14, and 2.2.1.4.1 of the YMRP (NRC 2003 [DIRS 163274] are included below. In cases where subsidiary criteria are listed in the YMRP for a given criterion, only the subsidiary criteria addressed by this scientific analysis are listed below. Where a subcriterion includes several components, only some of those components may be addressed. How these components are addressed is summarized in Section 7.2 of this report.

The acceptance criteria considered in this analysis report differ from those listed in the technical work plan (BSC 2004 [DIRS 169573]). Some additional acceptance criteria were addressed while other criteria were determined to not apply to this analysis.

\section{Acceptance Criteria from Section 2.2.1.3.13, Redistribution of Radionuclides in Soil}

\section{Acceptance Criterion 1, System Description and Model Integration Are Adequate.}

(1) Total system performance assessment adequately incorporates important features, physical phenomena and couplings between different models, and uses consistent and appropriate 
assumptions throughout the abstraction of redistribution of radionuclides in the soil abstraction process;

(2) The total system performance assessment model abstraction identifies and describes aspects of redistribution of radionuclides in soil that are important to repository performance, including the technical bases for these descriptions. For example, the abstraction should include modeling of the deposition of contaminated material in the soil and determination of the depth distribution of the deposited radionuclides;

(3) Relevant site features, events, and processes have been appropriately modeled in the abstraction of redistribution of radionuclides, from surface processes, and sufficient technical bases are provided.

\section{Acceptance Criterion 2, Data Are Sufficient for Model Justification.}

(1) Behavioral, hydrological, and geochemical values used in the license application are adequately justified (e.g., irrigation and precipitation rates, erosion rates, radionuclide solubility values, etc.). Adequate descriptions of how the data were used, interpreted, and appropriately synthesized into the parameters are provided; and

(2) Sufficient data (e.g., field, laboratory, and natural analog data) are available to adequately define relevant parameters and conceptual models necessary for developing the abstraction of redistribution of radionuclides in soil in the total system performance assessment.

\section{Acceptance Criterion 3, Data Uncertainty Is Characterized and Propagated Through the Model Abstraction.}

(1) Models use parameter values, assumed ranges, probability distributions, and bounding assumptions that are technically defensible, reasonably account for uncertainties and variabilities, do not result in an under-representation of the risk estimate, and are consistent with the characteristics of the reasonably maximally exposed individual in 10 CFR Part 63;

(2) The technical bases for the parameter values and ranges in the total system performance assessment abstraction are consistent with data from the Yucca Mountain region, e.g., Amargosa Valley survey, studies of surface processes in the Fortymile Wash drainage basin, applicable laboratory testings, natural analogs, or other valid sources of data. For example, soil types, crop types, plow depths, and irrigation rates should be consistent with current farming practices, and data on the airborne particulate concentration should be based on the resuspension of appropriate material in a climate and level of disturbance similar to that which is expected to be found at the location of the reasonably maximally exposed individual, during the compliance time period;

(3) Uncertainty is adequately represented in parameters for conceptual models, process models, and alternative conceptual models considered in developing the total system performance assessment abstraction of redistribution of radionuclides in soil, either through sensitivity analyses, conservative limits, or bounding values supported by data, as necessary. Correlations between input values are appropriately established in the total system performance assessment; 
(4) Parameters or models that most influence repository performance based on the performance measure and time period of compliance, specified in 10 CFR Part 63, are identified.

\section{Acceptance Criteria from Section 2.2.1.3.14, Biosphere Characteristics}

\section{Acceptance Criterion 1, System Description and Model Integration Are Adequate.}

(1) Total system performance assessment adequately incorporates important site features, physical phenomena, and couplings, and consistent and appropriate assumptions throughout the biosphere characteristics modeling abstraction process.

(2) The total system performance assessment model abstraction identifies and describes aspects of the biosphere characteristics modeling that are important to repository performance, and includes the technical bases for these descriptions. For example, the reference biosphere should be consistent with the arid or semi-arid conditions in the vicinity of Yucca Mountain.

(3) Assumptions are consistent between the biosphere characteristics modeling and other abstractions. For example, the U.S. Department of Energy should ensure that the modeling of features, events, and processes, such as climate change, soil types, sorption coefficients, volcanic ash properties, and the physical and chemical properties of radionuclides are consistent with assumptions in other total system performance assessment abstractions.

\section{Acceptance Criterion 2, Data Are Sufficient for Model Justification.}

(1) The parameter values used in the license application are adequately justified (e.g., behaviors and characteristics of the residents of the Town of Amargosa Valley, Nevada, characteristics of the reference biosphere, etc.) and consistent with the definition of the reasonably maximally exposed individual in 10 CFR Part 63. Adequate descriptions of how the data were used, interpreted, and appropriately synthesized into the parameters are provided.

(2) Data are sufficient to assess the degree to which features, events, and processes related to biosphere characteristics modeling have been characterized and incorporated in the abstraction. As specified in 10 CFR Part 63, the U.S. Department of Energy should demonstrate that features, events, and processes, which describe the biosphere, are consistent with present knowledge of conditions in the region, surrounding Yucca Mountain. As appropriate, the U.S. Department of Energy sensitivity and uncertainty analyses (including consideration of alternative conceptual models) are adequate for determining additional data needs, and evaluating whether additional data would provide new information that could invalidate prior modeling results and affect the sensitivity of the performance of the system to the parameter value or model.

\section{Acceptance Criterion 3, Data Uncertainty Is Characterized and Propagated Through the} Model Abstraction.

(1) Models use parameter values, assumed ranges, probability distributions, and bounding assumptions that are technically defensible, reasonably account for uncertainties and variabilities, do not result in an under-representation of the risk estimate, and are consistent with the definition of the reasonably maximally exposed individual in 10 CFR Part 63. 
(2) The technical bases for the parameter values and ranges in the abstraction, such as consumption rates, plant and animal uptake factors, mass-loading factors, and biosphere dose conversion factors, are consistent with site characterization data, and are technically defensible.

(4) Uncertainty is adequately represented in parameter development for conceptual models and process-level models considered in developing the biosphere characteristics modeling, either through sensitivity analyses, conservative limits, or bounding values supported by data, as necessary. Correlations between input values are appropriately established in the total system performance assessment, and the implementation of the abstraction does not inappropriately bias results to a significant degree.

(6) Parameters or models that most influence repository performance, based on the performance measure and time period of compliance specified in 10 CFR Part 63, are identified.

Acceptance Criteria from Section 2.2.1.4.1, Demonstration of Compliance with the Postclosure Public Health and Environmental Standards

Acceptance Criterion 2, An Adequate Demonstration Is Provided That the Annual Dose to the Reasonably Maximally Exposed Individual in Any Year During the Compliance Period Does Not Exceed the Exposure Standard.

(1) A sufficient number of realizations has been obtained, for each scenario class, using the total system performance assessment code, to ensure that the results of the calculations are statistically stable.

(2) The annual dose curve includes confidence intervals (e.g., $95^{\text {th }}$ and $5^{\text {th }}$ percentile) to represent the uncertainty in the dose calculations.

\subsection{CODES, STANDARDS, AND REGULATIONS}

No codes or standards, other than those identified in the Project Requirements Document (Canori and Leitner 2003 [DIRS 166275], Table 2-3) and determined to be applicable, were used in this analysis. 


\section{INTENTIONALLY LEFT BLANK}




\section{ASSUMPTIONS}

No assumptions were used in this analysis. 


\section{INTENTIONALLY LEFT BLANK}




\section{SCIENTIFIC ANALYSIS DISCUSSION}

The objectives of this analysis are to evaluate the output of the biosphere model, BDCFs, from the perspective of parameter, process, and pathway importance and sensitivity.

This section contains the description of the framework for the biosphere modeling (Section 6.1) and the discussion of important pathways, processes, and parameters for the groundwater (Section 6.2) and volcanic ash (Section 6.3) exposure scenarios.

\subsection{GENERAL CONSIDERATIONS}

\subsubsection{Radionuclides Included in the Analysis}

The biosphere model was constructed for 28 radionuclides identified as important for the TSPA for scenario classes involving radionuclide releases to groundwater. These radionuclides are referred in this analysis as primary radionuclides, and include: carbon-14 $\left({ }^{14} \mathrm{C}\right)$, chlorine-36 $\left({ }^{36} \mathrm{Cl}\right)$, selenium-79 $\left({ }^{79} \mathrm{Se}\right)$, strontium-90 $\left({ }^{90} \mathrm{Sr}\right)$, technetium-99 $\left({ }^{99} \mathrm{Tc}\right)$, tin-126 $\left({ }^{126} \mathrm{Sn}\right)$, iodine-129 $\left({ }^{129} \mathrm{I}\right)$, cesium-135 $\left({ }^{135} \mathrm{Cs}\right)$, cesium-137 $\left({ }^{137} \mathrm{Cs}\right)$, lead-210 $\left({ }^{210} \mathrm{~Pb}\right)$, radium-226 $\left({ }^{226} \mathrm{Ra}\right)$, actinium-227 $\left({ }^{227} \mathrm{Ac}\right)$, thorium-229 $\left({ }^{229} \mathrm{Th}\right)$, thorium-230 $\left({ }^{230} \mathrm{Th}\right)$, thorium-232 $\left({ }^{232} \mathrm{Th}\right)$, protactinium-231 $\left({ }^{231} \mathrm{~Pa}\right)$, uranium-232 $\left({ }^{232} \mathrm{U}\right)$, uranium-233 $\left({ }^{233} \mathrm{U}\right)$, uranium-234 $\left({ }^{234} \mathrm{U}\right)$, uranium-236 $\left({ }^{236} \mathrm{U}\right)$, uranium-238 $\left({ }^{238} \mathrm{U}\right)$, neptunium-237 $\left({ }^{237} \mathrm{~Np}\right)$, plutonium-238 $\left({ }^{238} \mathrm{Pu}\right)$, plutonium-239 $\left({ }^{239} \mathrm{Pu}\right)$, plutonium-240 $\left({ }^{240} \mathrm{Pu}\right)$, plutonium-242 $\left({ }^{242} \mathrm{Pu}\right)$, americium-241 $\left({ }^{241} \mathrm{Am}\right)$, and americium-243 ( $\left.{ }^{243} \mathrm{Am}\right)$ (BSC 2004 [DIRS 169460], Section 6.1.3).

The following 23 primary radionuclides were identified as important for the TSPA scenario classes involving radionuclide release during a volcanic eruption: ${ }^{90} \mathrm{Sr},{ }^{99} \mathrm{Tc},{ }^{126} \mathrm{Sn},{ }^{137} \mathrm{Cs},{ }^{210} \mathrm{~Pb}$, ${ }^{226} \mathrm{Ra},{ }^{227} \mathrm{Ac},{ }^{229} \mathrm{Th},{ }^{230} \mathrm{Th},{ }^{232} \mathrm{Th},{ }^{231} \mathrm{~Pa},{ }^{232} \mathrm{U},{ }^{233} \mathrm{U},{ }^{234} \mathrm{U},{ }^{236} \mathrm{U},{ }^{238} \mathrm{U},{ }^{237} \mathrm{~Np},{ }^{238} \mathrm{Pu},{ }^{239} \mathrm{Pu},{ }^{240} \mathrm{Pu}$, ${ }^{242} \mathrm{Pu},{ }^{241} \mathrm{Am}$, and ${ }^{243} \mathrm{Am}$ (BSC 2004 [DIRS 169460], Section 6.1.3). Both lists include radionuclides that are of potential importance during the first 20,000 years and the period of up to 1 million years (BSC 2004 [DIRS 169460], Section 6.1.3).

The biosphere model accounts for the decay products of the primary radionuclides. The short-lived decay products (half-lives less than 180 days) are considered to be in secular equilibrium with the parent radionuclide, and their contributions to the BDCFs are included in the BDCF for the long-lived radionuclide (either a primary radionuclide or its long-lived decay product) (BSC 2004 [DIRS 169460], Sections 6.3.1.4 and 6.3.5). The biosphere model also accounts for the decay and ingrowth of the long-lived decay products in the soil and adds BDCF contributions of the long-lived decay products to that of the parent primary radionuclide (BSC 2004 [DIRS 169460], Section 6.4.1.2). Two decay products of the primary radionuclides, ${ }^{228} \mathrm{Th}$ and ${ }^{228} \mathrm{Ra}$, have half-lives greater than 180 days and are not automatically included in the BDCFs of the parent when the biosphere model is executed. For biosphere modeling, ${ }^{228} \mathrm{Th}$ and ${ }^{228} \mathrm{Ra}$ are treated like primary radionuclides. After BDCFs are calculated for these radionuclides, their BDCFs are added to the BDCF of the parent primary radionuclide. In the case of ${ }^{232} \mathrm{Th}$, the BDCF includes the contribution from ${ }^{228} \mathrm{Ra},{ }^{228} \mathrm{Th}$, and their short-lived decay products. The BDCF for ${ }^{232} \mathrm{U}$ includes the contribution from ${ }^{228} \mathrm{Th}$ and its short-lived decay products. The list of primary radionuclides and the decay products included in the BDCF for a primary radionuclide is shown in Table 6.1-1. 
Table 6.1-1. Primary Radionuclides and Decay Products Included in the Biosphere Dose Conversion Factors

\begin{tabular}{|l|l|}
\hline Primary Radionuclide & \\
\hline C-14 & \\
\hline Cl-36 & \\
\hline Se-79 & Decay Products Included in BDCF \\
\hline Sr-90 & \\
\hline Tc-99 & \\
\hline Sn-126 & \\
\hline I-129 & \\
\hline Cs-135 & Ba-137m \\
\hline Cs-137 & Bi-210, Po-210 \\
\hline Pb-210 & Rn-222, Po-218, Pb-214, At-218, Bi-214, Po-214, Tl-210 \\
\hline Ra-226 & Th-227, Fr-223, Ra-223, Rn-219, Po-215, Pb-211, Bi-211, Tl-207, Po-211 \\
\hline Ac-227 & Ra-225, Ac-225, Fr-221, At-223, Bi-213, Po-213, Tl-209, Pb-209 \\
\hline Th-229 & \\
\hline Th-230 & Ra-228, Ac-228, Th-228, Ra-224, Rn-220, Po-216, Pb-212, Bi-212, Po-212, Tl-208 \\
\hline Th-232 & \\
\hline Pa-231 & Th-228, Ra-224, Rn-220, Po-216, Pb-212, Bi-212, Po-212, Tl-208 \\
\hline U-232 & \\
\hline U-233 & \\
\hline U-234 & \\
\hline U-236 & Th-234, Pa-234m, Pa-234 \\
\hline U-238 & Pa-233 \\
\hline Np-237 & \\
\hline Pu-238 & \\
\hline Pu-239 & \\
\hline Pu-240 & \\
\hline Pu-242 & \\
\hline Am-241 & \\
\hline Am-243 & \\
\hline & \\
\hline
\end{tabular}

\subsubsection{Description of the Exposure Scenarios}

Scenario classes considered for TSPA include the nominal scenario class and the disruptive scenario classes (BSC 2003 [DIRS 166296], pp. 51 to 52). The nominal scenario class represents the most likely evolution of the repository system and includes favorable and some potentially adverse future conditions. The disruptive event scenario classes consider combinations of FEPs that have a low probability of occurrence but may produce additional potentially adverse future conditions. The disruptive event scenario classes include the igneous (which includes the igneous intrusion and volcanic eruption cases) and seismic classes, as well as a special case analyzing the stylized intrusion of a human into the repository. TSPA scenarios consider radionuclide release from the repository in either groundwater or volcanic tephra. These two release modes match the two biosphere exposure scenarios and the associated biosphere models developed to support the TSPA analyses and described in the Biosphere Model 
Report (BSC 2004 [DIRS 169460]). The biosphere exposure scenarios consider radiological consequences of radionuclide releases to the reference biosphere in groundwater or volcanic tephra.

\section{Groundwater Exposure Scenario}

BDCFs for the groundwater exposure scenario are used to calculate annual doses in the TSPA modeling cases that consider groundwater release of radionuclides from the repository at Yucca Mountain. The nominal scenario class and some modeling cases from the disruptive scenario classes (i.e., igneous intrusion and human intrusion) may result in such a release. For this scenario, radionuclides enter the biosphere from wells that extract contaminated groundwater from an aquifer. Human exposure arises from using the contaminated water for domestic and agricultural purposes.

A detailed description of the groundwater exposure scenario, including the associated conceptual and mathematical models, is presented in the Biosphere Model Report (BSC 2004 [DIRS 169460], Sections 6.3.1 and 6.4).

\section{Volcanic Ash Exposure Scenario}

BDCFs for the volcanic ash exposure scenario are used for calculation of expected dose in the TSPA volcanic eruption modeling case. The initial source of radionuclides in the biosphere for the volcanic ash exposure scenario is contaminated volcanic ash deposited on the ground surface as the result of a volcanic eruption.

After radionuclides enter the biosphere, radionuclide migration through the biosphere occurs due to a number of transport processes that lead to contamination and accumulation in the environmental media (e.g., soil, air, flora, and fauna). Human exposure to radionuclides in the environment arises when people come in contact with contaminated environmental media.

A detailed description of the volcanic ash exposure scenario, including the associated conceptual and mathematical models, is presented in the Biosphere Model Report (BSC 2004 [DIRS 169460], Sections 6.3.2 and 6.5).

\subsubsection{Receptor Used in the Biosphere Model}

The regulations for licensing the repository include a postclosure individual protection standard for the performance of the repository that has a reasonable expectation of being achieved. This standard is expressed as the annual dose limit to the RMEI (10 CFR 63.311 [DIRS 156605]). Analysis of annual dose includes all potential pathways of radionuclide transport and exposure (10 CFR 63.311 [DIRS 156605]). Changes in the reference biosphere, other than those due to a change in climate, are not included.

To meet the requirements of 10 CFR 63.312(b) [DIRS 156605], the dietary and lifestyle characteristics of the RMEI were determined based on surveys of people living in the Amargosa Valley. 


\subsubsection{Consideration of Climate Change}

For modeling climate change for TSPA, the climate shifts in a series of step changes between three climate states in the first 10,000 years: present-day climate, monsoon climate (warmer and much wetter than the present-day climate), and glacial transition climate (colder and wetter, but not substantially wetter, than the present-day climate) (BSC 2003 [DIRS 166296], p. 79, BSC 2004 [DIRS 170002], Section 7.1). Within the TSPA model, these shifts require coordinating the coupled submodels, because they must all simultaneously change to the appropriate climate state. To support climate change for the nominal exposure scenario, BDCFs are developed for three climate states (BSC 2004 [DIRS 169674], Section 6.2.2). For the volcanic release scenario, climate changes have been shown to have little effect on BDCFs, and TSPA is provided with a single but conservative set (BSC 2004 [DIRS 167287], Section 6.2.5).

This analysis includes the discussion of climate influence on the BDCFs and input parameters. Two climates referred to throughout the analysis are the climate extremes for the compliance period, that is, the mean present-day climate and the upper bound of the glacial transition climate. These two climates constitute the average bounding cases for the climates expected during the period encompassed by the TSPA. The mean present-day climate is for brevity referred to thereafter as the present-day climate; the upper bound of the glacial transition climate is referred to as the future climate.

\subsubsection{Biosphere Model}

The ERMYN model (BSC 2004 [DIRS 169460]) is used to calculate BDCFs by modeling transport of radionuclides introduced into the biosphere and evaluating receptor exposure. The Biosphere Model Report (BSC 2004 [DIRS 169460]) describes the ERMYN model. Input parameters for the biosphere model were developed and documented in a series of five model parameter reports: BSC 2004 [DIRS 169673], BSC 2004 [DIRS 169671], BSC 2004 [DIRS 169672], BSC 2004 [DIRS 169458], and BSC 2004 [DIRS 169459].

The biosphere model calculates radionuclide-specific BDCFs. For the groundwater exposure scenario, a BDCF is numerically equal to the all-pathway annual dose that the RMEI would receive if groundwater containing a unit activity concentration of a given radionuclide were extracted from wells and used for irrigation or domestic purposes. A radionuclide-specific BDCFs for the volcanic ash exposure scenario consist of a set of three components representing different exposure pathways and conditions and are developed for the unit activity deposited per unit area of the soil surface.

BDCFs for groundwater and volcanic ash exposure scenarios were calculated, using probabilistic analysis, in a series of simulations for each primary radionuclide and two long-lived decay products, ${ }^{228} \mathrm{Th}$ and ${ }^{228} \mathrm{Ra}$ (Section 6.1.1). Each simulation resulted in 1,000 model realizations. A model realization is one of the possible model outcomes obtained as a result of a single round of sampling of the model input parameters.

Uncertainty in the model outcome is represented by the probability distributions of the BDCFs and it arises from propagating input parameters uncertainty onto the modeling results. Input 
parameter values were sampled using latin hypercube sampling for consistency with the sampling technique to be used in the TSPA-LA (BSC 2003 [DIRS 166296], Section 7.3).

\subsection{IDENTIFICATION OF IMPORTANT PATHWAYS, PROCESSES AND PARAMETERS FOR THE GROUNDWATER EXPOSURE SCENARIO}

This section uses results of the runs of the biosphere model for the groundwater exposure scenario included in DTN: MO0407MWDGSBMF.000 [DIRS 170852] except for the deterministic runs. For the deterministic runs, the input was obtained from the model input data files (DTNs: MO0403SPAAEIBM.002 [DIRS 169392]; MO0407SPAINEXI.002 [DIRS 170597]; MO0407SPASRPBM.002 [DIRS 170755]; MO0406SPAETPBM.002 [DIRS 170150]; MO0407SPACRBSM.002 [DIRS 170677]), as described in Section 4.1.

\subsubsection{Distributions of Biosphere Dose Conversion Factors}

This section evaluates the distributions of all BDCFs and examines the trends in their values and their causes. Each run of the biosphere model for the groundwater exposure scenario for a given radionuclide produced 1,000 model realizations, that is, 1,000 BDCF values, each for a different set of input parameter values. BDCFs were calculated for three climate states, as described in Section 6.1.4. The BDCF statistics are summarized in the Nominal Performance Biosphere Dose Conversion Factor Analysis (BSC 2004 [DIRS 169674], Tables 6.2-5, 6.2-6, and 6.2-7 for the present-day, monsoon, and glacial transition climates, respectively).

To calculate BDCFs for each climate state, BDCF values were first calculated for the present-day climate (which is also representative of the lower bound of the monsoon climate) and the upper bound of the glacial transition climate, using the full suite of variable input parameters, including those that have climate-specific values for those climates. These BDCFs incorporated variation and uncertainty in current conditions at Yucca Mountain and the analogue locations representative of the upper bound of the glacial transition climate. The BDCFs for the present-day climate were used in the TSPA for that climate state (BSC 2004 [DIRS 169674], Section 6.2.2).

To incorporate variation in the predicted future climate states, BDCFs for the monsoon and glacial transition climates were calculated for each model realization by interpolation between the BDCFs for the climate extremes (i.e., the present-day and the upper bound of the glacial transition climates) for a realization using the annual average irrigation rate as a scaling factor. For the bounds of the monsoon and the glacial transition climate states, the value of this parameter was estimated from the analogue weather stations. The average minimum $(0.52 \mathrm{~m} / \mathrm{yr})$ and maximum $(0.94 \mathrm{~m} / \mathrm{yr})$ irrigation rates for the monsoon climate encompassed almost the entire range of average irrigation rates between the upper bound glacial transition $(0.50 \mathrm{~m} / \mathrm{yr})$ and present-day (0.94 m/yr) climates (BSC 2004 [DIRS 169673], Section 6.5.2). Therefore, for each realization, the BDCF for the monsoon climate was a randomly selected value between the calculated BDCFs for the upper bound glacial transition and present-day climates. The range of irrigation rates for the glacial transition $(0.50$ to $0.88 \mathrm{~m} / \mathrm{yr})$ was about 86 percent of the range between the upper bound glacial transition and the present-day climate. Therefore, for each realization, the BDCF for the glacial transition climate was a randomly selected value between the calculated BDCF for the upper bound glacial transition and 86 percent of the calculated 
BDCF for the present-day climate. Interpolation between the bounds of each climate state based on differences in annual irrigation rate was valid because that parameter had the greatest influence on climate-dependent changes in BDCFs for most radionuclides and because BDCFs increased approximately linearly as annual irrigation rate increased (BSC 2004 [DIRS 169674], Section 6.2.2).

Figure 6.2-1 shows the ranges of BDCFs for all primary radionuclides, including their mean and median values, minima and maxima, as well as the $5^{\text {th }}$ and $95^{\text {th }}$ percentiles. The variance in the BDCF values is a result of the input parameter variability and uncertainty that is propagated into the model output. A number of trends can be observed in the BDCF values. First, the mean BDCF values for non-actinides generally increase with increasing mass of a radionuclide. The mean BDCF values for the actinides are generally higher than those for the lighter radionuclides and are roughly within an order of magnitude of each other, with the values for ${ }^{226} \mathrm{Ra}$ and isotopes of thorium being the highest.

To better show the span of the BDCF values and identify radionuclides that have the lowest and the highest BDCF values, the BDCFs were sorted in ascending order by the value of the means (Figure 6.2-2). The BDCF values are the highest for the radionuclides with relatively high atomic numbers and generally tend to decrease with the decreasing atomic number. The lowest BDCF value is for ${ }^{99} \mathrm{Tc}$; the highest is for ${ }^{231} \mathrm{~Pa}$ and ${ }^{226} \mathrm{Ra}$. The high value for ${ }^{226} \mathrm{Ra}$ is due to the contribution from inhalation of radon decay products. The high value for ${ }^{231} \mathrm{~Pa}$ arises from a tendency of protactinium to accumulate in the soil (relatively high partition coefficient, $\mathrm{K}_{\mathrm{d}}$ ) and its relatively high inhalation dose per unit activity intake. The difference between the highest and the lowest BDCFs is almost 5 orders of magnitude.

Figures 6.2-1 and 6.2-2 show that the degree of variance in the BDCF values differs greatly among the radionuclides. The minimum-to-maximum range is much wider than the $5^{\text {th }}$ to $95^{\text {th }}$ percentile range of the BDCF values. The BDCF for ${ }^{36} \mathrm{Cl}$ has the widest minimum-to-maximum range of BDCF values, extending over about 2.4 orders of magnitude; the range for ${ }^{90} \mathrm{Sr}$ is only half an order of magnitude (a factor of about 3.1). The $5^{\text {th }}$ to $95^{\text {th }}$ percentile range is much narrower, spanning from a factor of 1.6 for ${ }^{90} \mathrm{Sr}$ up to about 1.3 orders of magnitude for ${ }^{233} \mathrm{U}$. For calculations, see Excel file GW BDCF Variability Plots.xls (Appendix A). 


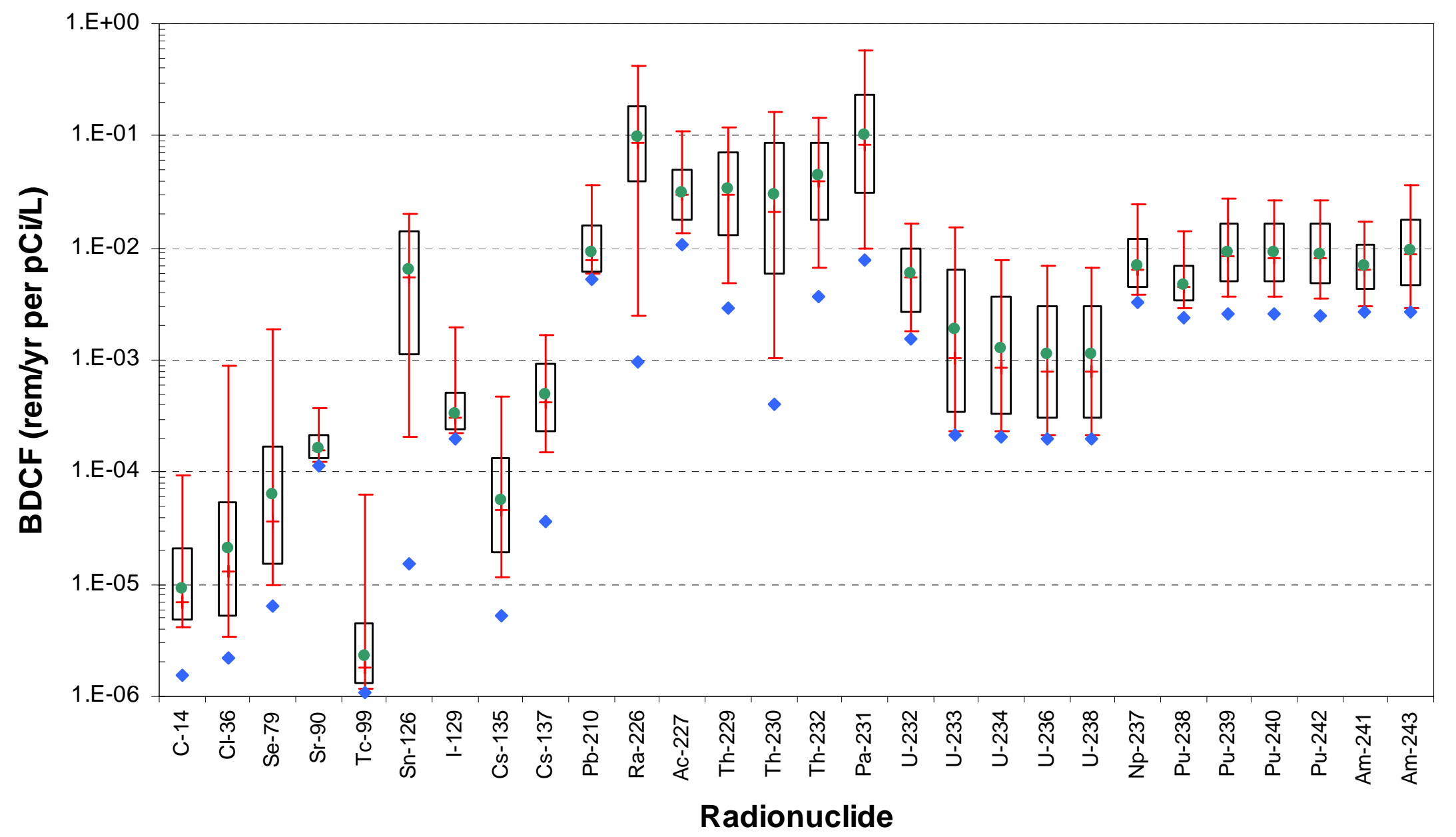

Source: Excel file GW BDCF Variability Plots.xIs (Appendix A).

NOTE: Boxes represent $5^{\text {th }}$ to $95^{\text {th }}$ percentile range. The vertical solid line represents the range and the tick mark on the line is the median. Diamond represents BDCF contributions from drinking water; circle represents the mean BDCF.

Figure 6.2-1. BDCF Distributions for the Groundwater Exposure Scenario and the Present-Day Climate 


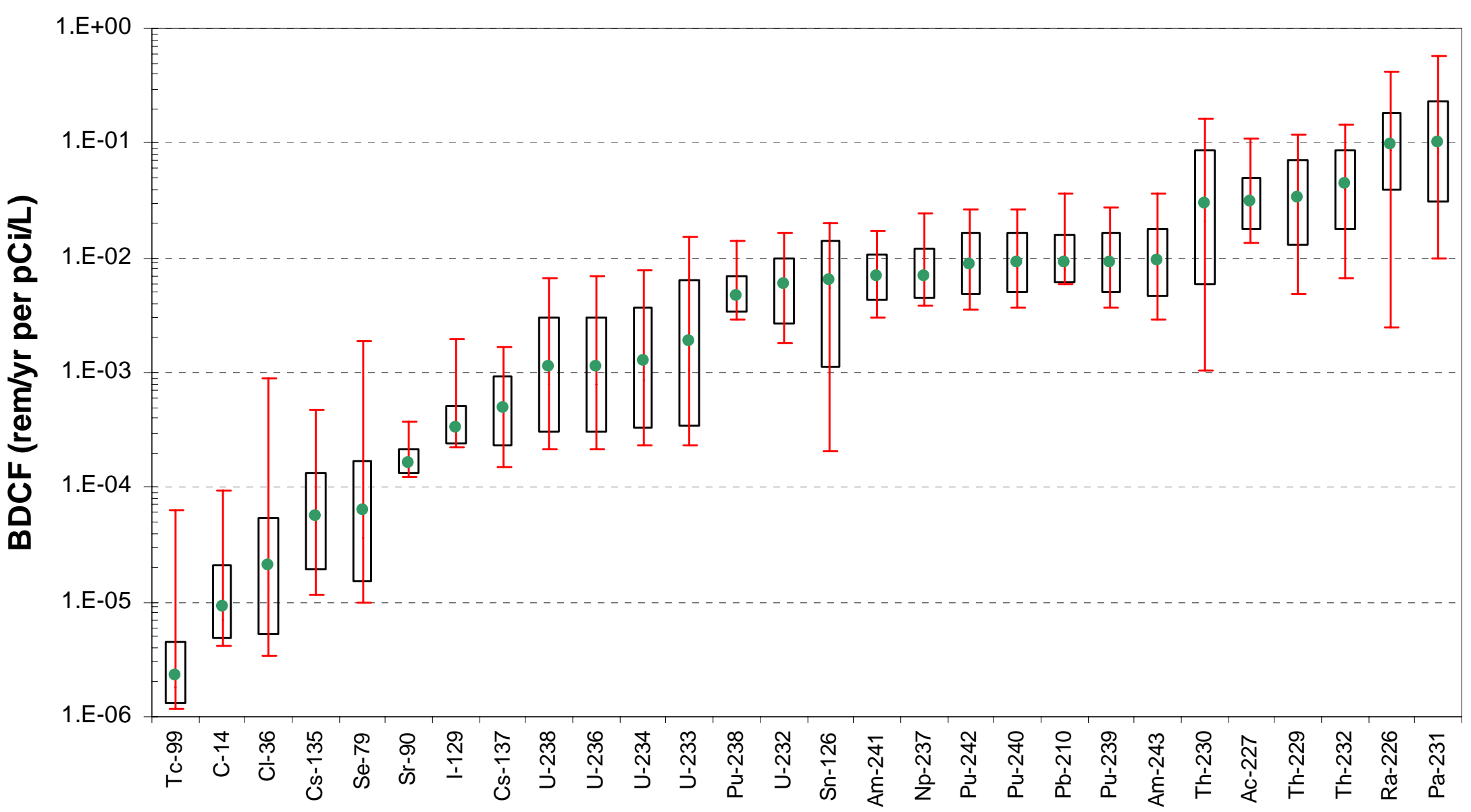

Radionuclide

Source: Excel file GW BDCF Variability Plots.xIs (Appendix A).

NOTE: Boxes represent $5^{\text {th }}$ to $95^{\text {th }}$ percentile range. The vertical solid line represents the range. Circle represents the mean BDCF.

Figure 6.2-2. BDCF Distributions for the Groundwater Exposure Scenario and the Present-Day Climate Sorted by the Mean BDCF Value 
The range in the BDCF values for a radionuclide can be better evaluated when the BDCFs are normalized to their mean value, as shown in Figure 6.2-3. This figure shows the distribution of BDCF values about the mean. The $5^{\text {th }}$ percentile values are within a factor of 0.18 to 0.82 of the mean BDCF, depending on a radionuclide. The $95^{\text {th }}$ percentiles are within a factor of 1.3 to 3.5 of the mean (for calculations see Excel file $G W B D C F$ Variability Plots.xls, worksheet $B D C F$ Normalized to Mean). The minimum values are from $0.03\left({ }^{126} \mathrm{Sn}\right.$ and $\left.{ }^{226} \mathrm{Ra}\right)$ to $0.75\left({ }^{90} \mathrm{Sr}\right)$ of the mean, and maximum values are from $2.3\left({ }^{90} \mathrm{Sr}\right)$ to about $43\left({ }^{36} \mathrm{Cl}\right)$ times greater than the mean.

Per 10 CFR 63.312(d), the drinking water component in the biosphere model is fixed; therefore, the distribution of BDCFs results from variability and uncertainty in the contributions from all other pathways. As a result, the distribution of BDCFs tends to be narrow if drinking water is an important pathway $\left({ }^{90} \mathrm{Sr},{ }^{129} \mathrm{I},{ }^{238} \mathrm{Pu}\right)$ and wider if the contribution of drinking water is less important. To show this, the drinking water contribution for individual radionuclides was subtracted from their BDCF statistics and the remainder normalized to its mean value (Figure 6.2-4). The variability (as measured by the $5^{\text {th }}$ to $95^{\text {th }}$ percentile levels) between normalized BDCF distributions, once the fixed drinking water component is removed, is more consistent among radionuclides than for the total normalized values. 


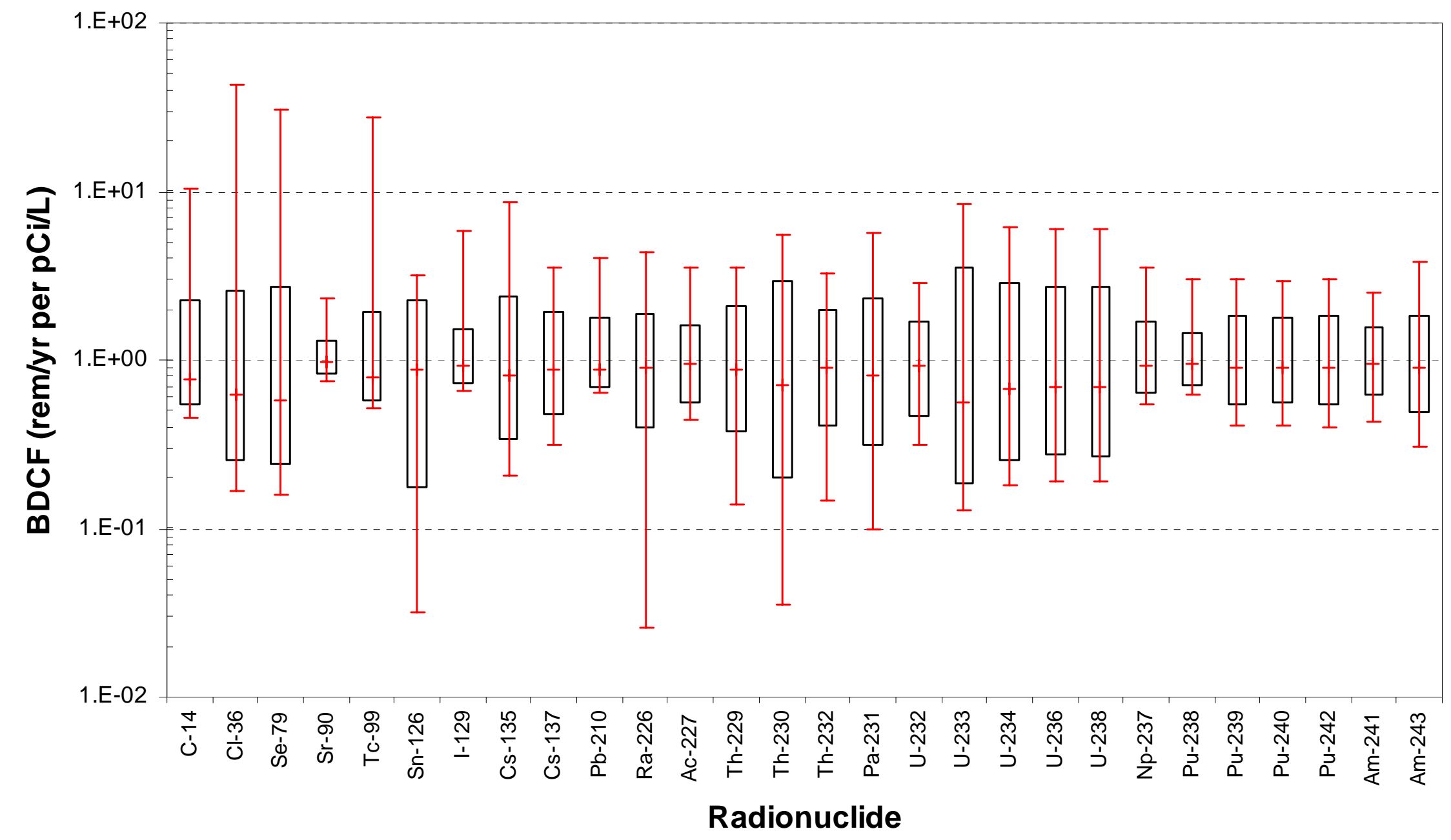

Source: Excel file GW BDCF Variability Plots.xIs (Appendix A).

NOTE: Boxes represent $5^{\text {th }}$ to $95^{\text {th }}$ percentile range. The vertical solid line represents the range and the tick mark on the line is the median.

Figure 6.2-3. BDCF Distributions for Groundwater Exposure Scenario, Present-Day Climate, Normalized to the Mean Value 


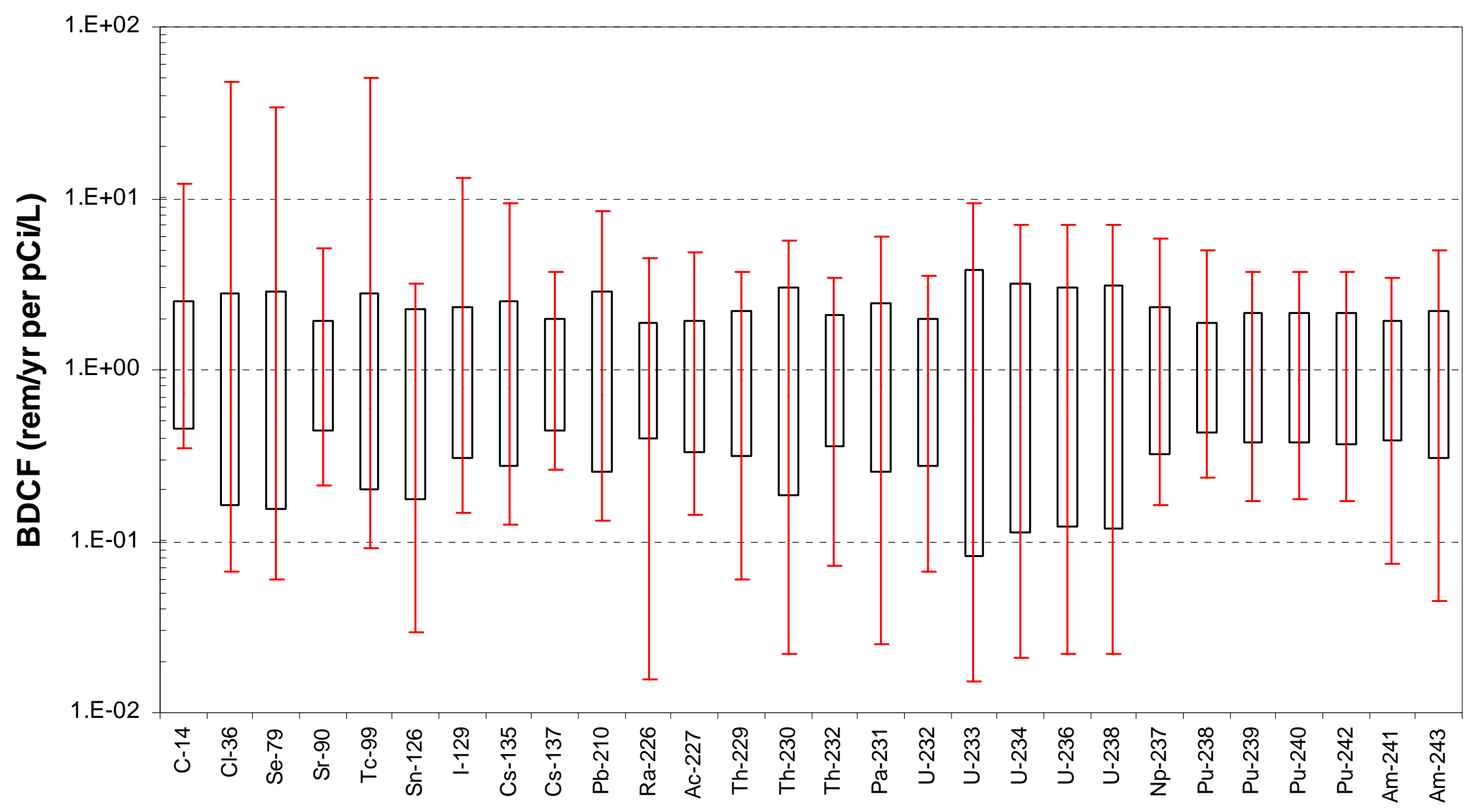

Radionuclide

Source: Excel file GW BDCF Variability Plots.xIs (Appendix A).

NOTE: Boxes represent $5^{\text {th }}$ to $95^{\text {th }}$ percentile range. The vertical solid line represents the range.

Figure 6.2-4. Distributions of the BDCFs (Exclusive of the Drinking Water Component) for Groundwater Exposure Scenario, Present-Day Climate, Normalized to the Mean Value 


\subsubsection{Summary of Pathway Analysis Results}

The aim of the pathway analysis is to identify those pathways that are important contributors to the BDCFs, so further analyses can focus on their contributing environmental transport and exposure pathways and the corresponding input parameters.

The biosphere model for the groundwater exposure scenario includes 15 exposure pathways. Pathway analysis was conducted, using the mean values of the BDCFs, to determine the relative importance of individual exposure pathways in terms of their contributions to BDCFs for various radionuclides (BSC 2004 [DIRS 169674], Section 6.2.5). The pathway contributions to the mean BDCF for the groundwater exposure scenario are reproduced in Tables 6.2-1 and 6.2-2.

Pathway contributions differ among radionuclides, and the RMEI's ingestion of water is a dominant pathway for most radionuclides. Ingestion of locally produced food is important for most radionuclides with atomic numbers less than about 88. Inhalation of particulate matter tends to dominate doses for actinides (e.g., isotopes of thorium, uranium, plutonium, and americium). Inhalation of radioactive aerosols generated by evaporative coolers also is an important inhalation exposure pathway for some of these radionuclides. Other pathways are only important for a few radionuclides. For instance, external exposure is a dominant pathway for

${ }^{126} \mathrm{Sn}$ and ${ }^{137} \mathrm{Cs}$; inhalation of radon decay products is important for ${ }^{226} \mathrm{Ra}$ and ${ }^{230} \mathrm{Th}$; and fish consumption is important for ${ }^{14} \mathrm{C}$, isotopes of cesium, and ${ }^{210} \mathrm{~Pb}$ (Table 6.2-1).

For the future climate, the importance of the evaporative cooler pathway is greatly reduced, as is the importance of the pathways that are related to radionuclide concentration in the surface soil (the equilibrium activity concentration in the surface soil is less because of the decreased irrigation rate) (Table 6.2-2). This increases the relative importance of the water ingestion pathway, which is a dominant pathway for many radionuclides. Inhalation of particulate matter remains an important pathway for the actinides (Table 6.2-2).

To visualize the results of the pathway analysis described above and to show the patterns in pathway importance for various radionuclides, Figures 6.2-5 and 6.2-6 show percent pathway contributions to the mean BDCF for several selected radionuclides for the present-day and future climates, respectively. The selected radionuclides include those radionuclides that were identified as important in previous performances assessments. The results of the TSPA for the supplemental science and performance analysis indicated that ${ }^{14} \mathrm{C}$, ${ }^{99} \mathrm{Tc}$, and ${ }^{129} \mathrm{I}$ were the most important dose contributors for nominal performance during the first 20,000 years postclosure (CRWMS M\&O 2000 [DIRS 153246], Figures 4.1-6 and 4.1-7). This coincides with the timeframe for the TSPA-LA (BSC 2003 [DIRS 166296], Section 1.3). Radionuclides important in the initial period are those that are relatively mobile in the environment. Transuranics tend to move more slowly in the environment because of their high sorption onto the solids. Three radionuclides, ${ }^{233} \mathrm{U},{ }^{237} \mathrm{~Np}$, and ${ }^{239} \mathrm{Pu}$ were selected to represent this group. 
Table 6.2-1. Exposure Pathway Contributions (Percent) for the Present-Day Climate Biosphere Dose Conversion Factors

\begin{tabular}{|c|c|c|c|c|c|c|c|c|c|c|c|c|c|c|c|}
\hline \multirow[b]{2}{*}{ RN } & \multirow[b]{2}{*}{$\begin{array}{c}\text { External } \\
\text { exposure }\end{array}$} & \multicolumn{3}{|c|}{ Inhalation } & \multicolumn{11}{|c|}{ Ingestion } \\
\hline & & $\begin{array}{c}\text { Particul. } \\
\text { Matter }\end{array}$ & $\begin{array}{l}\text { Evap. } \\
\text { Cooler }\end{array}$ & Radon & Water & $\begin{array}{l}\text { Leafy } \\
\text { Veget. }\end{array}$ & $\begin{array}{l}\text { Other } \\
\text { Veget. }\end{array}$ & Fruit & Grain & Meat & Milk & Poultry & Eggs & Fish & Soil \\
\hline C-14 & 0.0 & 0.0 & 0.0 & 0.0 & 16.8 & 2.8 & 5.0 & 13.0 & 0.6 & 7.0 & 3.3 & 0.6 & 5.5 & 45.3 & 0.0 \\
\hline $\mathrm{Cl}-36$ & 0.1 & 0.0 & 0.2 & 0.0 & 10.7 & 3.2 & 4.9 & 16.5 & 2.6 & 22.7 & 18.5 & 0.0 & 9.0 & 11.4 & 0.0 \\
\hline Se-79 & 0.0 & 0.1 & 0.0 & 0.0 & 10.3 & 0.7 & 0.5 & 1.6 & 0.1 & 55.1 & 3.2 & 2.0 & 21.9 & 3.8 & 0.6 \\
\hline Sr-90 & 0.5 & 0.1 & 0.3 & 0.0 & 68.2 & 6.6 & 3.7 & 6.2 & 0.6 & 3.0 & 3.7 & 0.0 & 1.6 & 5.1 & 0.4 \\
\hline Tc-99 & 0.0 & 0.0 & 0.7 & 0.0 & 47.2 & 12.0 & 2.1 & 7.7 & 0.5 & 4.3 & 13.5 & 0.2 & 10.0 & 1.6 & 0.0 \\
\hline Sn-126 & 98.2 & 0.0 & 0.0 & 0.0 & 0.2 & 0.0 & 0.0 & 0.0 & 0.0 & 0.4 & 0.0 & 0.0 & 0.1 & 1.0 & 0.0 \\
\hline I-129 & 0.1 & 0.1 & 0.1 & 0.0 & 59.9 & 2.6 & 0.7 & 3.0 & 0.4 & 5.0 & 7.5 & 0.2 & 14.2 & 5.4 & 0.8 \\
\hline Cs-135 & 0.0 & 0.1 & 0.0 & 0.0 & 9.3 & 1.4 & 0.9 & 4.2 & 0.2 & 10.3 & 5.8 & 7.3 & 5.5 & 54.0 & 1.1 \\
\hline Cs-137 & 43.0 & 0.0 & 0.0 & 0.0 & 7.6 & 0.4 & 0.1 & 0.5 & 0.0 & 1.7 & 1.0 & 0.9 & 0.7 & 44.1 & 0.1 \\
\hline $\mathrm{Pb}-210$ & 0.0 & 0.2 & 0.5 & 0.0 & 58.8 & 2.6 & 0.6 & 2.3 & 0.3 & 0.3 & 0.2 & 0.1 & 1.4 & 32.4 & 0.4 \\
\hline Ra-226 & 6.8 & 0.3 & 0.0 & 89.2 & 1.0 & 0.3 & 0.2 & 0.6 & 0.0 & 0.1 & 0.1 & 0.0 & 0.7 & 0.1 & 0.6 \\
\hline Ac-227 & 0.3 & 16.8 & 42.6 & 0.0 & 34.7 & 1.4 & 0.3 & 1.2 & 0.1 & 0.1 & 0.0 & 0.0 & 0.0 & 2.2 & 0.2 \\
\hline Th-229 & 3.0 & 71.9 & 12.5 & 0.0 & 8.6 & 0.5 & 0.1 & 0.4 & 0.0 & 0.1 & 0.0 & 0.0 & 0.0 & 1.8 & 0.9 \\
\hline Th-230 & 5.7 & 13.6 & 2.2 & 74.5 & 1.4 & 0.3 & 0.1 & 0.6 & 0.0 & 0.1 & 0.1 & 0.0 & 0.6 & 0.3 & 0.6 \\
\hline Th-232 & 25.0 & 53.9 & 8.8 & 0.0 & 8.2 & 0.7 & 0.2 & 0.6 & 0.1 & 0.1 & 0.1 & 0.0 & 0.0 & 1.5 & 0.9 \\
\hline Pa-231 & 1.3 & 84.7 & 2.5 & 0.0 & 7.7 & 0.6 & 0.2 & 0.8 & 0.1 & 0.1 & 0.0 & 0.0 & 0.0 & 0.2 & 1.8 \\
\hline U-232 & 12.3 & 20.6 & 33.9 & 0.0 & 26.6 & 1.1 & 0.3 & 0.9 & 0.1 & 0.1 & 0.1 & 0.2 & 0.8 & 2.7 & 0.3 \\
\hline U-233 & 1.3 & 68.3 & 14.3 & 0.0 & 11.4 & 0.6 & 0.2 & 0.6 & 0.1 & 0.1 & 0.1 & 0.2 & 1.6 & 0.3 & 0.9 \\
\hline U-234 & 0.4 & 52.3 & 20.4 & 4.9 & 16.2 & 0.8 & 0.2 & 0.7 & 0.1 & 0.1 & 0.1 & 0.3 & 2.2 & 0.5 & 0.7 \\
\hline U-236 & 0.0 & 54.9 & 21.7 & 0.0 & 17.3 & 0.8 & 0.2 & 0.8 & 0.1 & 0.1 & 0.2 & 0.4 & 2.3 & 0.5 & 0.8 \\
\hline U-238 & 3.7 & 52.1 & 20.6 & 0.0 & 17.3 & 0.8 & 0.2 & 0.8 & 0.1 & 0.1 & 0.2 & 0.4 & 2.4 & 0.5 & 0.8 \\
\hline Np-237 & 2.6 & 22.5 & 15.2 & 0.0 & 46.5 & 2.6 & 1.0 & 4.3 & 0.2 & 0.9 & 0.0 & 0.0 & 0.0 & 3.0 & 1.2 \\
\hline Pu-238 & 0.0 & 20.6 & 16.4 & 0.0 & 49.8 & 2.1 & 0.5 & 1.7 & 0.2 & 0.0 & 0.0 & 0.0 & 0.0 & 7.3 & 1.1 \\
\hline Pu-239 & 0.0 & 52.5 & 9.1 & 0.0 & 27.9 & 1.5 & 0.3 & 1.3 & 0.2 & 0.0 & 0.0 & 0.0 & 0.1 & 4.1 & 2.9 \\
\hline $\mathrm{Pu}-240$ & 0.0 & 51.5 & 9.4 & 0.0 & 28.7 & 1.5 & 0.3 & 1.3 & 0.2 & 0.0 & 0.0 & 0.0 & 0.1 & 4.2 & 2.8 \\
\hline Pu-242 & 0.0 & 53.1 & 9.1 & 0.0 & 27.5 & 1.5 & 0.3 & 1.3 & 0.2 & 0.0 & 0.0 & 0.0 & 0.1 & 4.1 & 2.9 \\
\hline Am-241 & 0.1 & 38.2 & 12.8 & 0.0 & 39.0 & 1.8 & 0.4 & 1.6 & 0.2 & 0.1 & 0.0 & 0.0 & 0.0 & 3.7 & 2.1 \\
\hline Am-243 & 5.6 & 49.0 & 9.1 & 0.0 & 27.7 & 1.5 & 0.3 & 1.3 & 0.1 & 0.1 & 0.0 & 0.0 & 0.0 & 2.6 & 2.7 \\
\hline
\end{tabular}




\begin{tabular}{|c|c|c|c|c|c|c|c|c|c|c|c|c|c|c|c|}
\hline \multirow[b]{2}{*}{ RN } & \multirow[b]{2}{*}{$\begin{array}{c}\text { External } \\
\text { exposure }\end{array}$} & \multicolumn{3}{|c|}{ Inhalation } & \multicolumn{11}{|c|}{ Ingestion } \\
\hline & & \begin{tabular}{|c|} 
Particul. \\
Matter
\end{tabular} & $\begin{array}{l}\text { Evap. } \\
\text { Cooler }\end{array}$ & Radon & Water & $\begin{array}{l}\text { Leafy } \\
\text { Veget. }\end{array}$ & $\begin{array}{l}\text { Other } \\
\text { Veget. }\end{array}$ & Fruit & Grain & Meat & Milk & Poultry & Eggs & Fish & Soil \\
\hline C-14 & 0.0 & 0.0 & 0.0 & 0.0 & 18.0 & 2.9 & 3.7 & 10.1 & 0.7 & 6.4 & 3.1 & \begin{tabular}{|l}
0.7 \\
\end{tabular} & 6.2 & 48.6 & 0.0 \\
\hline $\mathrm{Cl}-36$ & 0.1 & 0.0 & 0.1 & 0.0 & 15.2 & 3.4 & 5.1 & 17.3 & 2.7 & 23.5 & 19.0 & 0.0 & 10.6 & 9.4 & 0.0 \\
\hline Se-79 & 0.0 & 0.1 & 0.0 & 0.0 & 15.0 & 0.7 & 0.4 & 1.4 & 0.1 & 48.6 & 2.9 & 1.7 & 19.1 & 3.2 & 0.5 \\
\hline Sr-90 & 0.3 & 0.1 & 0.1 & 0.0 & 78.4 & 4.8 & 2.4 & 3.9 & 0.4 & 2.1 & 2.6 & 0.0 & 1.2 & 3.4 & 0.2 \\
\hline Tc-99 & 0.0 & 0.0 & 0.2 & 0.0 & 56.4 & 10.7 & 1.8 & 6.3 & 0.5 & 3.8 & 11.8 & 0.2 & 9.2 & 1.1 & 0.0 \\
\hline Sn-126 & 97.7 & 0.0 & 0.0 & 0.0 & 0.4 & 0.0 & 0.0 & 0.0 & 0.0 & 0.4 & 0.0 & 0.0 & 0.1 & 1.0 & 0.0 \\
\hline I-129 & 0.1 & 0.1 & 0.0 & 0.0 & 69.0 & 2.1 & 0.5 & 1.9 & 0.3 & 3.9 & 5.8 & 0.2 & 11.6 & 3.6 & 0.6 \\
\hline Cs-135 & 0.0 & 0.1 & 0.0 & 0.0 & 15.1 & 1.3 & 0.8 & 3.7 & 0.2 & 9.4 & 5.2 & 6.6 & 5.0 & 51.1 & 1.0 \\
\hline Cs-137 & 37.9 & 0.0 & 0.0 & 0.0 & 12.6 & 0.4 & 0.1 & 0.5 & 0.0 & 1.7 & 1.0 & 0.9 & 0.7 & 42.7 & 0.1 \\
\hline $\mathrm{Pb}-210$ & 0.0 & 0.1 & 0.1 & 0.0 & 71.1 & 2.2 & 0.4 & 1.4 & 0.2 & 0.2 & 0.1 & 0.0 & 1.2 & 22.6 & 0.3 \\
\hline Ra-226 & 6.1 & 0.3 & 0.0 & 89.4 & 1.7 & 0.3 & 0.1 & 0.5 & 0.0 & 0.1 & 0.1 & 0.0 & 0.6 & 0.1 & 0.5 \\
\hline Ac-227 & 0.3 & 15.8 & 16.4 & 0.0 & 61.6 & 1.8 & 0.3 & 1.0 & 0.2 & 0.1 & 0.0 & 0.0 & 0.0 & 2.3 & 0.2 \\
\hline Th-229 & 3.0 & 72.2 & 5.1 & 0.0 & 16.1 & 0.6 & 0.1 & 0.4 & 0.1 & 0.1 & 0.0 & 0.0 & 0.1 & 2.0 & 0.9 \\
\hline Th-230 & 5.3 & 12.6 & 0.8 & 77.6 & 2.4 & 0.3 & 0.1 & 0.5 & 0.0 & 0.1 & 0.1 & 0.0 & 0.5 & 0.3 & 0.6 \\
\hline Th-232 & 24.5 & 52.9 & 3.5 & 0.0 & 14.9 & 0.8 & 0.2 & 0.5 & 0.1 & 0.1 & 0.1 & 0.0 & 0.0 & 1.6 & 0.9 \\
\hline $\mathrm{Pa}-231$ & 1.3 & 81.4 & 1.0 & 0.0 & 13.5 & 0.7 & 0.2 & 0.7 & 0.1 & 0.1 & 0.0 & 0.0 & 0.0 & 0.2 & 1.8 \\
\hline U-232 & 12.1 & 20.3 & 13.2 & 0.0 & 47.5 & 1.4 & 0.2 & 0.9 & 0.2 & 0.1 & 0.1 & 0.2 & 1.0 & 2.8 & 0.3 \\
\hline U-233 & 1.4 & 72.3 & 5.8 & 0.0 & 21.1 & 0.8 & 0.2 & 0.6 & 0.1 & 0.1 & 0.1 & 0.3 & 1.8 & 0.4 & 0.9 \\
\hline U-234 & 0.4 & 54.0 & 8.1 & 5.8 & 29.7 & 1.0 & 0.2 & 0.7 & 0.1 & 0.1 & 0.2 & 0.4 & 2.4 & 0.5 & 0.8 \\
\hline U-236 & 0.0 & 57.0 & 8.7 & 0.0 & 31.8 & 1.1 & 0.2 & 0.8 & 0.1 & 0.1 & 0.2 & 0.4 & 2.6 & 0.6 & 0.8 \\
\hline U-238 & 3.8 & 53.6 & 8.2 & 0.0 & 31.7 & 1.0 & 0.2 & 0.8 & 0.1 & 0.1 & 0.2 & 0.4 & 2.6 & 0.6 & 0.8 \\
\hline $\mathrm{Np}-237$ & 2.2 & 18.9 & 4.5 & 0.0 & 63.7 & 2.4 & 0.8 & 3.6 & 0.2 & 0.8 & 0.0 & 0.0 & 0.0 & 2.4 & 1.0 \\
\hline Pu-238 & 0.0 & 15.2 & 5.0 & 0.0 & 69.2 & 2.1 & 0.3 & 1.2 & 0.2 & 0.0 & 0.0 & 0.0 & 0.0 & 5.9 & 0.8 \\
\hline Pu-239 & 0.0 & 44.4 & 3.1 & 0.0 & 43.5 & 1.6 & 0.3 & 1.0 & 0.2 & 0.0 & 0.0 & 0.0 & 0.1 & 3.7 & 2.5 \\
\hline Pu-240 & 0.0 & 43.3 & 3.2 & 0.0 & 44.4 & 1.6 & 0.3 & 1.0 & 0.2 & 0.0 & 0.0 & 0.0 & 0.1 & 3.8 & 2.4 \\
\hline Pu-242 & 0.0 & 45.0 & 3.1 & 0.0 & 43.0 & 1.6 & 0.3 & 1.0 & 0.2 & 0.0 & 0.0 & 0.0 & 0.1 & 3.7 & 2.5 \\
\hline Am-241 & 0.1 & 30.3 & 4.1 & 0.0 & 57.4 & 1.9 & 0.3 & 1.2 & 0.2 & 0.1 & 0.0 & 0.0 & 0.0 & 3.1 & 1.7 \\
\hline Am-243 & 4.8 & 41.6 & 3.1 & 0.0 & 43.5 & 1.5 & 0.3 & 1.0 & 0.2 & 0.1 & 0.0 & 0.0 & 0.0 & 2.4 & 2.3 \\
\hline
\end{tabular}




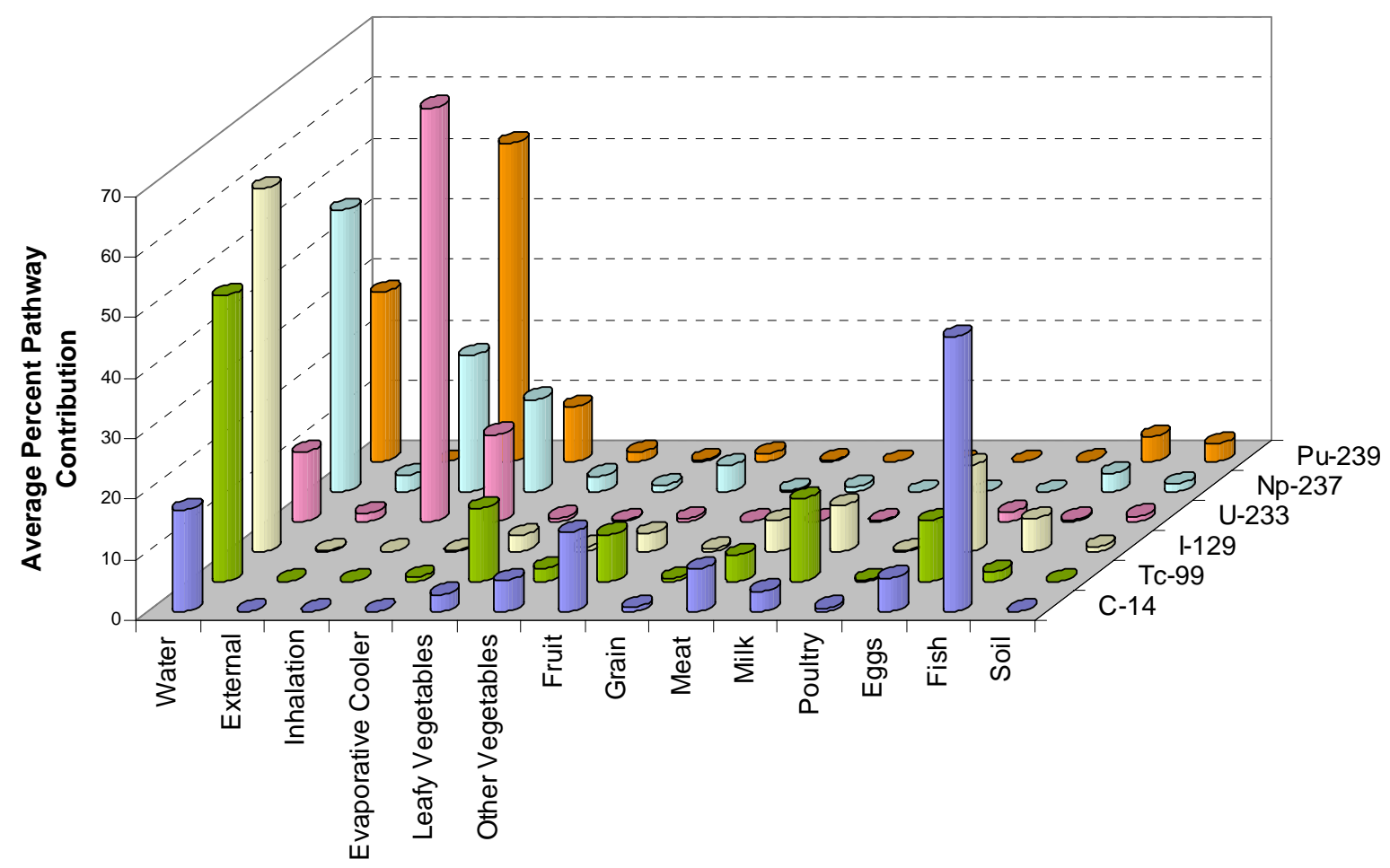

Source: Excel file Detailed Pathway Analysis GW_MC.xls (Appendix A).

Figure 6.2-5. Pathway Contributions for the Groundwater Exposure Scenario and Present-Day Climate

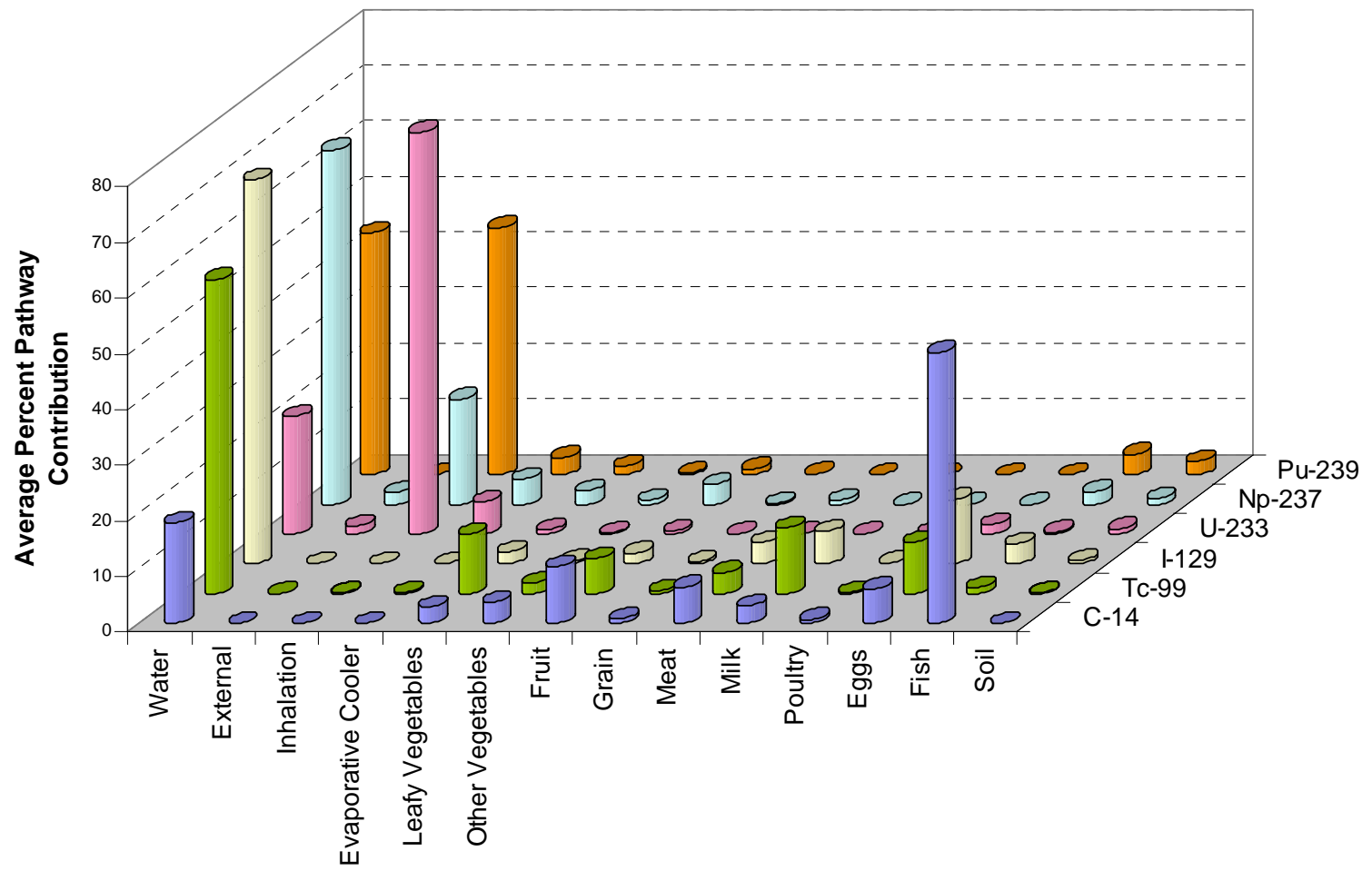

Source: Excel file Detailed Pathway Analysis GW_MC.xIs (Appendix A).

Figure 6.2-6. Pathway Contributions for the Groundwater Exposure Scenario and Future Climate 
The variation associated with the major exposure pathways for the present-day climate for the radionuclides shown in Figure 6.2-5 is illustrated in Figure 6.2-7.
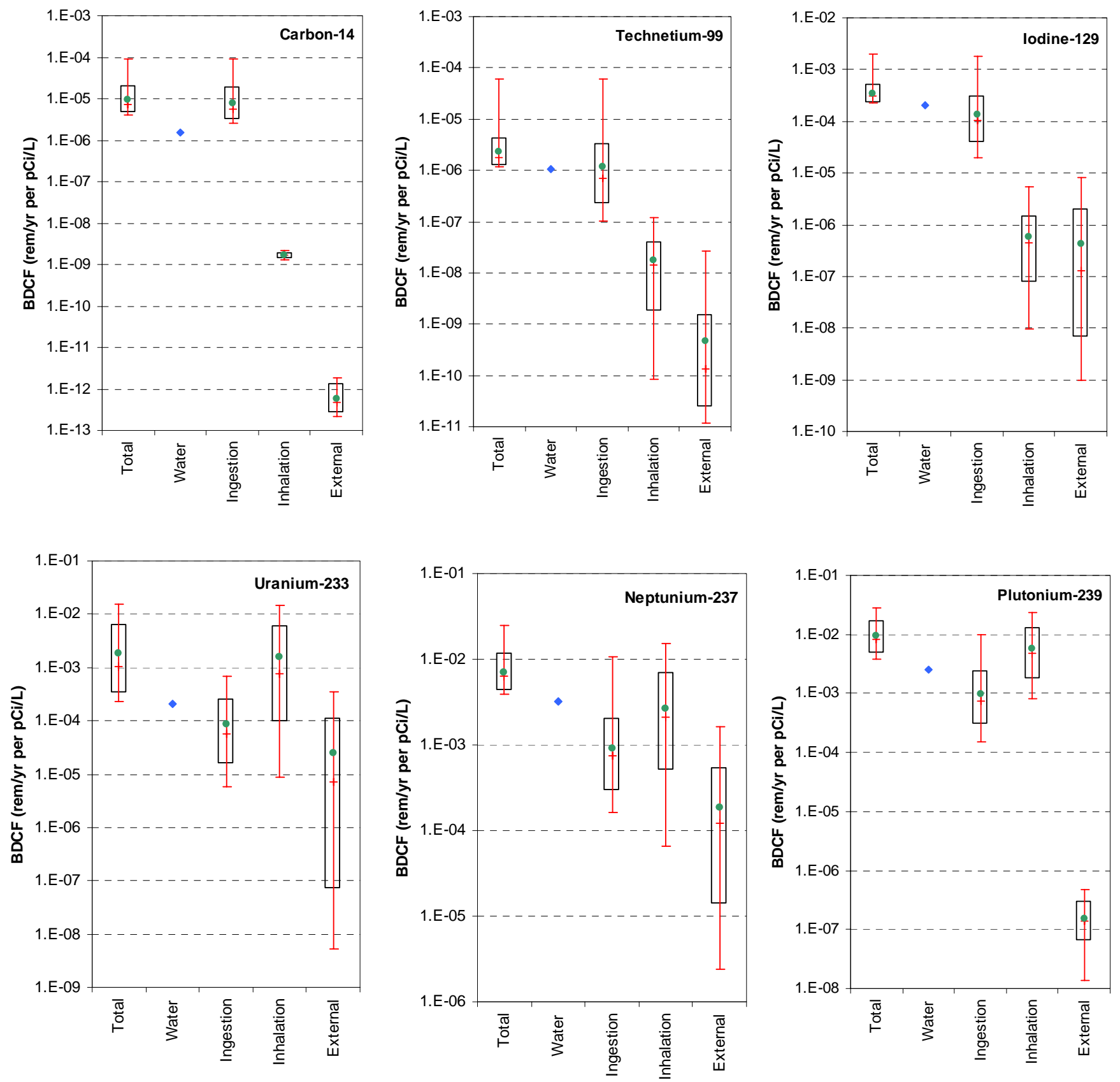

Source: Excel file GW BDCF Variability Plots.xls (Appendix A).

NOTE: Boxes represent $5^{\text {th }}$ to $95^{\text {th }}$ percentile range for the groundwater exposure scenario BDCFs for the present-day climate. Vertical solid line represents the range and the tick mark on the line is the median. Diamonds represent BDCF contributions from drinking water; circles represent the mean values.

Figure 6.2-7. Uncertainty Associated with the Major Exposure Pathway BDCFs for Selected Radionuclides, Present-Day Climate 


\subsubsection{Sources of Uncertainty in the Biosphere Dose Conversion Factors}

The source of variance in the BDCF values (see Figures 6.2-1 to 6.2-4) is the uncertainty and variability in the values of the input parameters for the biosphere model. The pathway importance and uncertainty contributions from the input parameters are not necessarily related. Frequently, the parameters that contribute the most to important pathways do not contribute to an appreciable degree, or even at all, to the variance in the BDCF. The obvious examples are parameters that are fixed, such as consumption of drinking water and the dose coefficients.

This section discusses the degree to which individual input parameters influences the BDCFs. This was quantified by calculation of rank correlation coefficients. A correlation coefficient is a number between -1 and 1 that measures the degree to which two variables are linearly related.

\subsubsection{Correlation Statistics for the Selected Radionuclides}

Correlation coefficients for the stochastic model input parameters and BDCFs for the groundwater exposure scenario were calculated for the selected radionuclides $\left({ }^{14} \mathrm{C},{ }^{99} \mathrm{Tc},{ }^{129} \mathrm{I}\right.$, ${ }^{233} \mathrm{U},{ }^{237} \mathrm{~Np}$, and ${ }^{239} \mathrm{Pu}$ ) (see Excel file GW MC Correlations.xls in Appendix A). The results are presented in Table 6.2-3 for the present-day climate. Only those correlations that are non-zero at the 99 percent confidence interval (absolute value of the correlation coefficient equal or greater than 0.0812) are shown in the table, plus the next correlation that is below this threshold (see Section 6.2.3.2 for calculation of the statistically significant value). The list includes the "false" correlations that are above the threshold value, as explained in Section 6.2.3.2.

Table 6.2-3. Correlation Coefficients for the Input Parameters and Biosphere Dose Conversion Factors for the Groundwater Exposure Scenario and the Present-Day Climate

\begin{tabular}{|c|c|c|c|}
\hline Radionuclide & Parameter Name & $\begin{array}{l}\text { Correlation } \\
\text { Coefficient }\end{array}$ & $\begin{array}{c}\text { Correlation } \\
\text { Coefficient Squared }\end{array}$ \\
\hline \multirow[t]{10}{*}{ Carbon-14 } & Bioaccumulation factor for fish & 0.886 & 0.786 \\
\hline & Fish Consumption rate & 0.309 & 0.096 \\
\hline & Wind Speed for Crops & -0.179 & 0.032 \\
\hline & Daily irrigation rate for other vegetables & 0.108 & 0.012 \\
\hline & Protactinium partition coefficient $\left(\mathrm{K}_{\mathrm{d}}\right)$ & -0.097 & 0.009 \\
\hline & Milk consumption rate & 0.089 & 0.008 \\
\hline & Protactinium transfer factor for other vegetables ${ }^{a}$ & 0.087 & 0.008 \\
\hline & Beef consumption rate & 0.085 & 0.007 \\
\hline & Protactinium transfer factor for leafy vegetables ${ }^{a}$ & 0.083 & 0.007 \\
\hline & Leafy vegetable consumption rate & 0.078 & 0.006 \\
\hline \multirow[t]{7}{*}{ Technetium-99 } & Overwatering rate & -0.637 & 0.406 \\
\hline & Technetium transfer coefficient for milk & 0.265 & 0.070 \\
\hline & Technetium transfer factor for leafy vegetables & 0.201 & 0.040 \\
\hline & Technetium transfer coefficient for meat & 0.179 & 0.032 \\
\hline & Technetium transfer factor for fruit & 0.174 & 0.030 \\
\hline & Technetium transfer coefficient for eggs & 0.159 & 0.025 \\
\hline & Technetium transfer factor for grain & 0.141 & 0.020 \\
\hline
\end{tabular}


Biosphere Dose Conversion Factor Importance and Sensitivity Analysis

Table 6.2-3. Correlation Coefficients for the Input Parameters and Biosphere Dose Conversion Factors for the Groundwater Exposure Scenario and the Present-Day Climate (Continued)

\begin{tabular}{|c|c|c|c|}
\hline Radionuclide & Parameter Name & $\begin{array}{l}\text { Correlation } \\
\text { Coefficient }\end{array}$ & $\begin{array}{c}\text { Correlation } \\
\text { Coefficient Squared } \\
\end{array}$ \\
\hline \multirow{11}{*}{$\begin{array}{l}\text { Technetium-99 } \\
\text { (Continued) }\end{array}$} & Dry-to-wet weight ratio for fruit & 0.141 & 0.020 \\
\hline & Technetium transfer factor for cattle forage & 0.137 & 0.019 \\
\hline & Technetium transfer factor for other vegetables & 0.131 & 0.017 \\
\hline & Weathering half-life & 0.129 & 0.017 \\
\hline & Technetium partition coefficient $\left(\mathrm{K}_{\mathrm{d}}\right)$ & -0.125 & 0.016 \\
\hline & Irrigation amount for cattle forage & -0.112 & 0.012 \\
\hline & Annual long-term irrigation rate & 0.111 & 0.012 \\
\hline & Uranium bioaccumulation factor for fish $^{a}$ & -0.106 & 0.011 \\
\hline & $\begin{array}{l}\text { Translocation factor for other vegetables, fruits } \\
\text { and grains }\end{array}$ & 0.095 & 0.009 \\
\hline & Uranium transfer coefficient for eggs $^{a}$ & -0.086 & 0.007 \\
\hline & Neptunium transfer factor for cattle forage ${ }^{a}$ & 0.074 & 0.006 \\
\hline \multirow[t]{21}{*}{ lodine-129 } & Iodine partition coefficient $\left(\mathrm{K}_{\mathrm{d}}\right)$ & 0.325 & 0.106 \\
\hline & Weathering half-life & 0.307 & 0.094 \\
\hline & Overwatering rate & -0.273 & 0.075 \\
\hline & Iodine transfer factor for fruit & -0.260 & 0.068 \\
\hline & Iodine transfer coefficient for eggs & 0.251 & 0.063 \\
\hline & Iodine transfer factor for other vegetables & -0.235 & 0.055 \\
\hline & Iodine transfer factor for leafy vegetables & -0.228 & 0.052 \\
\hline & Iodine bioaccumulation factor for fish & 0.207 & 0.043 \\
\hline & Iodine transfer factor for cattle forage & -0.206 & 0.042 \\
\hline & lodine transfer factor for grain & -0.204 & 0.042 \\
\hline & Yield, forage & -0.196 & 0.038 \\
\hline & $\begin{array}{l}\text { Translocation factor for other vegetables, fruits } \\
\text { and grains }\end{array}$ & 0.183 & 0.034 \\
\hline & Irrigation intensity & -0.163 & 0.027 \\
\hline & lodine transfer coefficient for meat & 0.157 & 0.025 \\
\hline & Iodine transfer coefficient for milk & 0.153 & 0.023 \\
\hline & Dry biomass, forage & 0.121 & 0.015 \\
\hline & Eggs consumption rate & 0.110 & 0.012 \\
\hline & Fish consumption rate & 0.095 & 0.009 \\
\hline & Mass loading in inactive outdoors environment & 0.088 & 0.008 \\
\hline & Tin transfer coefficient for meat ${ }^{a}$ & 0.085 & 0.007 \\
\hline & Technetium transfer coefficient for poultry ${ }^{\mathrm{a}}$ & 0.079 & 0.006 \\
\hline \multirow[t]{6}{*}{ Uranium-233 } & Uranium partition coefficient $\left(K_{d}\right)$ & 0.822 & 0.676 \\
\hline & Uranium transfer factor for fruit & -0.655 & 0.429 \\
\hline & Uranium transfer factor for cattle forage & -0.651 & 0.423 \\
\hline & Uranium transfer factor for grain & -0.645 & 0.416 \\
\hline & Uranium transfer factor for leafy vegetables & -0.629 & 0.395 \\
\hline & Uranium transfer factor for other vegetables & -0.612 & 0.375 \\
\hline
\end{tabular}


Biosphere Dose Conversion Factor Importance and Sensitivity Analysis

Table 6.2-3. Correlation Coefficients for the Input Parameters and Biosphere Dose Conversion Factors for the Groundwater Exposure Scenario and the Present-Day Climate (Continued)

\begin{tabular}{|c|c|c|c|}
\hline Radionuclide & Parameter Name & $\begin{array}{l}\text { Correlation } \\
\text { Coefficient }\end{array}$ & $\begin{array}{c}\text { Correlation } \\
\text { Coefficient Squared }\end{array}$ \\
\hline \multirow{9}{*}{$\begin{array}{l}\text { Uranium-233 } \\
\text { (Continued) }\end{array}$} & Overwatering rate & -0.245 & 0.060 \\
\hline & Evaporative cooler water transfer fraction & 0.212 & 0.045 \\
\hline & Erosion rate & -0.184 & 0.034 \\
\hline & $\begin{array}{l}\text { Enhancement factor for active outdoors } \\
\text { environment }\end{array}$ & 0.167 & 0.028 \\
\hline & Mass loading for active outdoors environment & 0.136 & 0.019 \\
\hline & Deposition velocity & 0.115 & 0.013 \\
\hline & Soil depth & 0.109 & 0.012 \\
\hline & Fraction of non-workers & -0.083 & 0.007 \\
\hline & $\begin{array}{l}\text { Time spent in active outdoors environment by } \\
\text { commuters }\end{array}$ & 0.070 & 0.005 \\
\hline \multirow[t]{22}{*}{ Neptunium-237 } & Overwatering rate & -0.519 & 0.269 \\
\hline & Neptunium partition coefficient $\left(\mathrm{K}_{\mathrm{d}}\right)$ & 0.471 & 0.222 \\
\hline & Neptunium transfer factor for other vegetables & -0.380 & 0.145 \\
\hline & Neptunium transfer factor for cattle forage & -0.380 & 0.144 \\
\hline & Neptunium transfer factor for leafy vegetables & -0.369 & 0.136 \\
\hline & Evaporative cooler water transfer fraction & 0.362 & 0.131 \\
\hline & Neptunium transfer factor for grain & -0.361 & 0.130 \\
\hline & Neptunium transfer factor for fruit & -0.277 & 0.077 \\
\hline & $\begin{array}{l}\text { Enhancement factor for active outdoors } \\
\text { environment }\end{array}$ & 0.217 & 0.047 \\
\hline & Mass loading for active outdoors environment & 0.183 & 0.033 \\
\hline & Neptunium bioaccumulation factor for fish & 0.117 & 0.014 \\
\hline & Deposition velocity & 0.099 & 0.010 \\
\hline & $\begin{array}{l}\text { Time spent in active outdoors environment by } \\
\text { non-workers }\end{array}$ & 0.095 & 0.009 \\
\hline & Erosion rate & -0.093 & 0.009 \\
\hline & Thorium transfer factor for grain ${ }^{a}$ & -0.087 & 0.008 \\
\hline & Strontium transfer coefficient for milk ${ }^{a}$ & 0.085 & 0.007 \\
\hline & Water usage in evaporative coolers & 0.085 & 0.007 \\
\hline & Long-term irrigation & 0.084 & 0.007 \\
\hline & Poultry consumption rate & -0.083 & 0.007 \\
\hline & Weathering half-life & 0.083 & 0.007 \\
\hline & Cesium transfer coefficient for eggs ${ }^{a}$ & 0.081 & 0.007 \\
\hline & Ventilation rate for evaporative coolers & 0.078 & 0.006 \\
\hline \multirow[t]{5}{*}{ Plutonium-239 } & Erosion rate & -0.534 & 0.285 \\
\hline & Mass loading for active outdoors environment & 0.475 & 0.226 \\
\hline & $\begin{array}{l}\text { Enhancement factor for active outdoors } \\
\text { environment }\end{array}$ & 0.368 & 0.135 \\
\hline & Plutonium partition coefficient $\left(\mathrm{K}_{\mathrm{d}}\right)$ & 0.265 & 0.070 \\
\hline & Plutonium transfer factor for leafy vegetables & -0.220 & 0.048 \\
\hline
\end{tabular}


Table 6.2-3. Correlation Coefficients for the Input Parameters and Biosphere Dose Conversion Factors for the Groundwater Exposure Scenario and the Present-Day Climate (Continued)

\begin{tabular}{|c|c|c|c|}
\hline Radionuclide & Parameter Name & $\begin{array}{l}\text { Correlation } \\
\text { Coefficient }\end{array}$ & $\begin{array}{c}\text { Correlation } \\
\text { Coefficient Squared }\end{array}$ \\
\hline \multirow{16}{*}{$\begin{array}{l}\text { Plutonium-239 } \\
\text { (Continued) }\end{array}$} & Plutonium transfer factor for cattle forage & -0.213 & 0.045 \\
\hline & Plutonium transfer factor for fruit & -0.209 & 0.043 \\
\hline & Evaporative cooler water transfer fraction & 0.199 & 0.040 \\
\hline & Plutonium transfer factor for other vegetables & -0.191 & 0.036 \\
\hline & Plutonium transfer factor for grain & -0.188 & 0.035 \\
\hline & Overwatering rate & -0.166 & 0.028 \\
\hline & $\begin{array}{l}\text { Time spent in active outdoors environment by } \\
\text { commuters }\end{array}$ & 0.142 & 0.020 \\
\hline & Plutonium bioaccumulation factor for fish & 0.119 & 0.014 \\
\hline & $\begin{array}{l}\text { Time spent in active outdoors environment by } \\
\text { non-workers }\end{array}$ & 0.111 & 0.012 \\
\hline & Fraction of outdoor workers & 0.109 & 0.012 \\
\hline & Actinium bioaccumulation factor for fish ${ }^{a}$ & -0.107 & 0.011 \\
\hline & Weathering half-life & 0.106 & 0.011 \\
\hline & Tin bioaccumulation factor for fish ${ }^{a}$ & -0.099 & 0.010 \\
\hline & Daily irrigation rate for other vegetables & 0.096 & 0.009 \\
\hline & Uranium transfer coefficient for poultry ${ }^{a}$ & -0.086 & 0.007 \\
\hline & Deposition velocity & 0.074 & 0.005 \\
\hline
\end{tabular}

Source: Excel file GW MC Correlations.xls (Appendix A).

${ }^{a}$ False correlations, as explained in Section 6.2.3.2.

For ${ }^{14} \mathrm{C}$, the greatest correlations are with the bioaccumulation factor in fish and the consumption rate of fish. Fish consumption is also the most important pathway (see Table 6.2-1). The other high correlation for the ${ }^{14} \mathrm{C}$ BDCF is a negative correlation with wind speed, which controls the activity concentration in the mixing cell for carbon dioxide released from the soil and thus crop uptake of ${ }^{14} \mathrm{C}$ through photosynthesis.

For ${ }^{99} \mathrm{Tc}$, the greatest correlation is with the overwatering rate. Overwatering rate is used to calculate the leaching removal constant (Section 6.2.4.1), which, in turn, affects the activity concentration in the soil and thus root uptake. BDCFs for ${ }^{99} \mathrm{Tc}$ are also correlated with the animal transfer coefficients, soil-to-plant transfer factors, weathering half-life, irrigation rates, and partition coefficient $\left(\mathrm{K}_{\mathrm{d}}\right)$.

Parameters that influence the BDCF for ${ }^{129} \mathrm{I}$ are related to radionuclide transport to soil, crops, and animal products. The weathering half life and the translocation factor that control the amount of activity externally deposited on a plant remaining in an edible product have higher correlation coefficients than those for ${ }^{99} \mathrm{Tc}$, indicating that this transport mechanism is more important for ${ }^{129}$ I than it is for ${ }^{99} \mathrm{Tc}$.

The variance in the BDCF for ${ }^{233} \mathrm{U}$ has its source primarily in the $K_{d}$ value followed by the transfer factors for crops. Other parameters that influence the level of radionuclides in the soil, such as the overwatering rate and erosion rate, are also important. In addition, some parameters 
in the calculation of the inhalation dose from airborne particulate matter and aerosols generated by evaporative coolers contribute to a lesser degree to variance in the BDCF.

For ${ }^{237} \mathrm{~Np}$ and ${ }^{239} \mathrm{Pu}$, air mass loading for the active outdoors environment and the enhancement factor for the same environment are among the input parameters with high correlation coefficients. The parameters that control the equilibrium level of activity concentration in the soil, such as the $K_{d} s$ and overwatering rate also tend to appear near the top of the list. Soil-to-plant transfer factors also have high correlation coefficients for these radionuclides because of the negative correlation between $\mathrm{K}_{d} \mathrm{~S}$ and transfer factors built into the biosphere model.

\subsubsection{Calculation of Correlation Statistics for Stochastic Input Parameters and Biosphere Dose Conversion Factors}

The GoldSim code used to generate the stochastic BDCF distributions provides the user with the capability to calculate correlation coefficients between any two or more distributions. This capability is used to provide a convenient indication of those input parameters that have a significant effect on the model results (i.e., the BDCFs). For example, for the BDCFs for ${ }^{99} \mathrm{Tc}$ presented in Table 6.2-3, the parameters with the absolute value of the correlation coefficient greater than or equal to 0.125 are provided in Table 6.2-4.

Table 6.2-4. Correlation Coefficients between BDCF Values for ${ }^{99} \mathrm{Tc}$ and Input Parameters with Absolute Values Greater than 0.125

\begin{tabular}{|l|c|}
\hline \multicolumn{1}{|c|}{ GoldSim Input Parameter } & Correlation Coefficient \\
\hline Overwatering rate & -0.637 \\
\hline Technetium transfer coefficient for milk & 0.265 \\
\hline Technetium transfer factor for leafy vegetables & 0.201 \\
\hline Technetium transfer coefficient for meat & 0.179 \\
\hline Technetium transfer factor for fruit & 0.174 \\
\hline Technetium transfer coefficient for eggs & 0.159 \\
\hline Technetium transfer factor for grain & 0.141 \\
\hline Dry-to-wet weight ratio for fruit & 0.141 \\
\hline Technetium transfer factor for cattle forage & 0.137 \\
\hline Technetium transfer factor for other vegetables & 0.131 \\
\hline Weathering half-life & 0.129 \\
\hline Technetium partition coefficient $\left(\mathrm{K}_{\mathrm{d}}\right)$ & -0.125 \\
\hline
\end{tabular}

Source: Excel file GW MC Correlations.xls (Appendix A).

$\mathrm{K}_{\mathrm{d}}=$ partition coefficient

As there are almost 300 stochastic input parameters for the groundwater exposure scenario, it is of interest to determine a value for the correlation coefficient below which there is no statistical significance, in order to identify those parameters that are inconsequential in determining the BDCFs. The details of such an approach is presented in Steel and Torrie (1980 [DIRS 150857] p. 279) where to test the null hypothesis of the true correlation coefficient $(\rho)$ being zero, the measured correlation coefficient $(r)$ is used to calculate trom Equation 6.2-1. The value of $t$ is 
then compared with Student's t for $n-2$ degrees of freedom ( $n=$ the number of data points used to derive $r$ ) for the required confidence interval.

$$
t=\frac{r}{\sqrt{\left(1-r^{2}\right) /(n-2)}}
$$

For generating the BDCFs, the number of realizations $(n)$ was 1,000. For a large number of degrees of freedom, the Student's $t$ distribution is closely approximated by the normal distribution, so the 95 percent confidence interval for the absolute value of $t$ is 1.96. Substituting these values into Equation 6.2-1 results in an absolute value of $r$, below which the null hypothesis would not be rejected, as 0.062 . The corresponding absolute value at the 99 percent confidence limit for rejecting the null hypothesis is 0.0812 .

When setting up GoldSim to conduct correlation coefficient calculations, the user selects the parameter against which the correlation will be made. In this case, the parameter is the output BDCF array. The user either can select, on a one-by-one basis, the input parameter distributions to use for the correlation or nominate to do the correlation matrix for all stochastic parameters. Without any prior sensitivity analysis, there is no basis to select any particular set of parameters for the correlation analysis; the normal default is to use all stochastic inputs to generate the matrix. In following this path, GoldSim automatically includes the radionuclide specific parameters for all radionuclides and not just the set for the radionuclide under consideration. In the case of ${ }^{99} \mathrm{Tc}$, some of these additional parameters are determined to be potentially significant, as shown in Table 6.2-5.

Table 6.2-5. Observed Correlation Coefficients between ${ }^{99} \mathrm{Tc}$ BDCF Values and Input Parameters for Other Radionuclides

\begin{tabular}{|l|c|}
\hline \multicolumn{1}{|c|}{ GoldSim Input Parameter } & Correlation Coefficient \\
\hline Irrigation amount for cattle forage & -0.112 \\
\hline Long-term irrigation rate & 0.111 \\
\hline Uranium bioaccumulation factor for fish & -0.106 \\
\hline Translocation factor for other vegetables, fruits and grains & 0.095 \\
\hline Uranium transfer coefficient for eggs & -0.086 \\
\hline
\end{tabular}

Source: Excel file GW MC Correlations.xls (Appendix A).

From the previous discussion on the significance of the parametric correlation, Table 6.2-5 appears to indicate some unexpected parameter correlation being generated by the GoldSim approach. Further investigation illustrates that the results in Table 6.2-5 are predictable.

In the ${ }^{99}$ Tc example, there are 172 stochastic parameters included in the biosphere model that are not associated with ${ }^{99}$ Tc but are associated with all the other radionuclides included in the model. GoldSim, once set up for a scenario, keeps track of all parameters whether or not they are radionuclide specific. Thus, by selecting to generate the correlation matrix for all stochastic parameters, these (redundant) 172 parameters are automatically included. The alternative, but tedious and error prone, approach is to individually select, one by one, the 100+ parameters that are used for the radionuclide being evaluated. 
When the statistical approach is used to test the null hypothesis that the actual correlation is not significantly different from zero, it is necessary to establish a confidence interval for accepting/rejecting the hypothesis. At the 95 percent confidence interval, a value is established for the measured correlation coefficient; if the correlation coefficient is less than this value, it is postulated that there are no underlying correlation between variables. If random tests (i.e., the GoldSim model run with a new random number seed) were performed a large number of times, in only 5 percent of cases would the observed value of the correlation lead to the rejection of the null hypothesis (i.e., exceed the cut-off value).

In the reported case, although GoldSim was run only once, the random test applies to each of the 172 parameters for which there is no ${ }^{99}$ Tc dependency. The analysis of calculating the measured and expected number of "significant" non-zero correlation values is relatively simple and is reported in Table 6.2-6 for the 172 independent (i.e., not correlated) parameters. The data in Excel file $G W M C$ Correlations.xls (Appendix A) show that the observed number of false correlation events is in line with the expected number. Consequently, GoldSim is behaving in a logical and consistent manner.

Table 6.2-6. The Number of Expected and Observed False Correlation Values for Independent Input Parameters as a Function of Confidence Level

\begin{tabular}{|c|c|c|c|c|}
\hline Confidence Level & $\mathbf{t}^{\mathbf{a}}$ & \begin{tabular}{c} 
Correlation $_{\text {Coefficient }^{\mathbf{b}}}$ \\
\hline $5.0 \%$
\end{tabular} Expected Number $^{\mathbf{c}}$ & Observed Number $^{\mathbf{d}}$ \\
\hline $2.0 \%$ & 2.96 & 0.062 & 8.6 & 7 \\
\hline $1.0 \%$ & 2.33 & 0.074 & 3.4 & 4 \\
\hline $0.2 \%$ & 2.58 & 0.081 & 1.7 & 2 \\
\hline
\end{tabular}

${ }^{a}$ Value of $t$ (see Equation 6.2-1) corresponding to the confidence level shown in the first column (from Steel and Torrie 1980 [DIRS 150857], Table A.4)

${ }^{b}$ Correlation coefficient corresponding to the value of $t$ (see Excel file GW MC Correlations.xIs (Appendix A)

${ }^{\mathrm{c}}$ Calculated as a product of the confidence level (first column) and 172 parameters.

${ }^{\mathrm{d}}$ From Excel file GW MC Correlations.xls (Appendix A)

\subsubsection{Analysis of the Environmental Transport Pathways and Radionuclide Accumulation in the Environmental Media}

The dose to the receptor from radionuclides in well water arises from the transport of radionuclides from water to environmental media (environmental transport pathways) and from human exposure to these media (receptor exposure pathways).

For many radionuclides, especially non-actinides, consumption of locally produced food is an important contributor to BDCFs. The doses from consumption of locally produced food depend on the radionuclide concentration in these foods and on their respective consumption rates. The relative importance of transport processes that contribute to radionuclide concentration in locally produced foods is discussed in this section.

Environmental transport pathways lead to radionuclide accumulation in the environmental media. The environmental media included in the biosphere model for the groundwater exposure scenario include well water (groundwater), surface soil, air, plants, animals, and fish. For the 
groundwater exposure scenario, water is the source of contamination in the biosphere. Surface soil becomes contaminated when well water is used for irrigation. Airborne contamination is a result of resuspension of contaminated soil and operation of evaporative coolers. Radionuclide accumulation in plants occurs as a result of transport from water, soil, and air. The source of radionuclide intake by animals is water, fodder crops, and soil.

\subsubsection{Radionuclide Accumulation in Surface Soil}

In the groundwater exposure scenario, surface soil is an environmental medium that can be considered a secondary source of contamination for many environmental transport and receptor exposure pathways (groundwater is a primary source). These pathways include resuspension of soil particles with the subsequent deposition on crops or inhalation by humans, external exposure, radionuclide uptake by crops through their roots, emission of radioactive gasses and their transport to crops and humans, and soil ingestion by humans and animals. In fact, there are only a few transport processes and pathways in the biosphere model that do not originate in the soil, namely the deposition of contaminated water on crop surfaces, water ingestion by humans and animals, and radionuclide bioaccumulation in fish. For the remaining pathways, activity concentration in soil has a direct effect on the outcome of the relevant submodels.

The source of radionuclides in the surface soil is from groundwater used for irrigation. The buildup of radionuclides in soil from this input is offset by the processes that remove radionuclides from the soil. Removal processes include leaching, surface soil erosion, and radioactive decay (a removal mechanism for the parent radionuclide, but a source for the decay product). Radionuclide concentrations in surface soil are calculated for equilibrium conditions. Generally, the change in radionuclide concentration in soil is equal to the rate of radionuclide input (irrigation), minus the rate of radionuclide loss. For equilibrium conditions, the rate of radionuclide addition is equal to the rate of radionuclide removal, with concentrations in the surface soil remaining constant. The biosphere model uses equilibrium radionuclide concentrations in surface soil for predicting root uptake of activity, for calculating radionuclide concentration in the atmosphere from resuspension of soil particles (for inhalation and attachment to foliage), and for inadvertent soil ingestion. The radionuclide concentration in surface soil is calculated in the biosphere model as (adapted from BSC 2004 [DIRS 169460], Equation 6.4.1-4):

$$
C s=\frac{C w I R}{\lambda_{d}+\lambda_{l}+\lambda_{e}}=\frac{C w I R}{\lambda_{e f f}}
$$

where

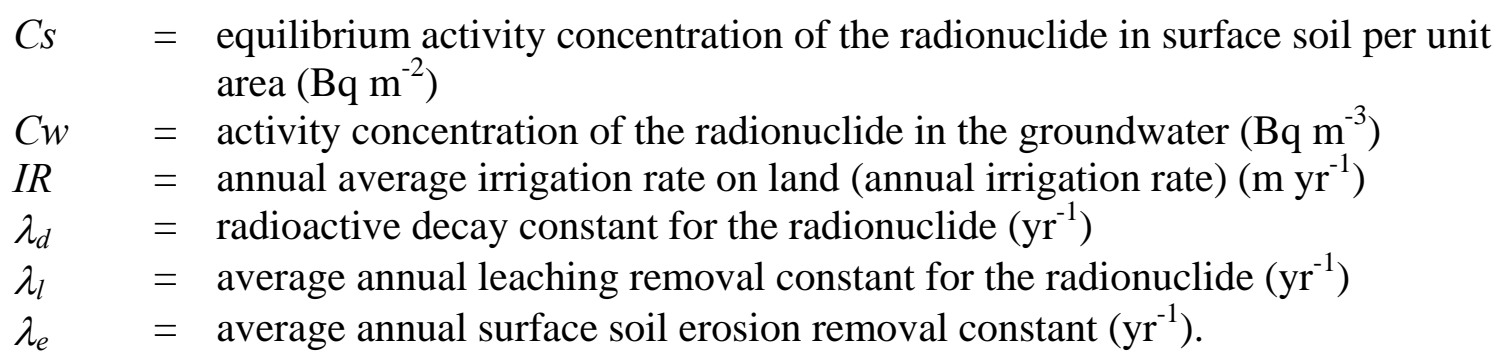


$\lambda_{\text {eff }}=$ effective removal constant

Equation 6.2-2 shows that the equilibrium radionuclide concentration in soil is directly proportional to the irrigation rate. The typical range of irrigation rates is from 0.5 to $1.0 \mathrm{~m} / \mathrm{yr}$ (BSC 2004 [DIRS 169673], Section 6.5.2). The average irrigation rate is time-dependent because of climate changes predicted for the Yucca Mountain region over the period of interest. However, because stochastic BDCFs are defined for each climate state predicted to occur to 10,000 years in the future, the average irrigation rate for a given climate is not a function of time. Annual average irrigation rates were developed using Food and Agriculture Organization methods based on determination of crop water requirements, which are calculated from evapotranspiration of a grass reference surface and adjusted with a crop-specific coefficient (BSC 2004 [DIRS 169673], Section 6.5.2). Parameter inputs were growing season lengths, average monthly weather data for the climate states under consideration, as well as salinity of irrigation water. These parameters are site-specific. The probability distribution of irrigation rate that is representative of long-term averages was developed such that the range of values extends from the $1^{\text {st }}$ to $99^{\text {th }}$ percentile of the irrigation rate values for representative crops. The dependence of the BDCFs on the value of annual average irrigation rate is shown in Figure 6.2-8 for selected radionuclides (see Excel file Dependence of $G W B D C F s$ on Inputs.xls in Appendix A).

The graphs were plotted using averaged values of the independent and dependent variables. If the unsorted data for individual realizations are plotted, the stochastic variability among BDCFs from the multiple random inputs results in plots that show little discernable trend. To generate a graph illustrating the effects of an input parameter on BDCFs, averaging over realizations was required to minimize the impact of other variables. The results of model realizations were sorted by the value of the independent variable (here the annual average irrigation rate). Then the irrigation rates and the corresponding BDCFs were averaged in blocks of 100 values. The calculations were performed and the graph generated in an Excel spreadsheet (Dependence of $G W$ BDCFs on Inputs.xls, Appendix A). The triangle symbols in the graph represent the mean of 100 values. The error bars represent the uncertainty range for the mean at the 95 percent uncertainty interval, calculated as 1.96 times the standard error of the mean. The standard error was calculated as standard deviation of the BDCF values in a block of 100 values divided by a square root of the number of results in a block, that is, $\sqrt{100}=10$.

There is one data point in the ${ }^{99}$ Tc graph (Figure 6.2-8) that is an outlier with a high BDCF value. If included in the plots, this outlier results in large error bars for the point that includes this value in the corresponding bin with 100 BDCF values. To better show the relationship between the input parameter and the BDCFs, this point was removed from the graphs for ${ }^{99} \mathrm{Tc}$ presented further in this analysis report. 

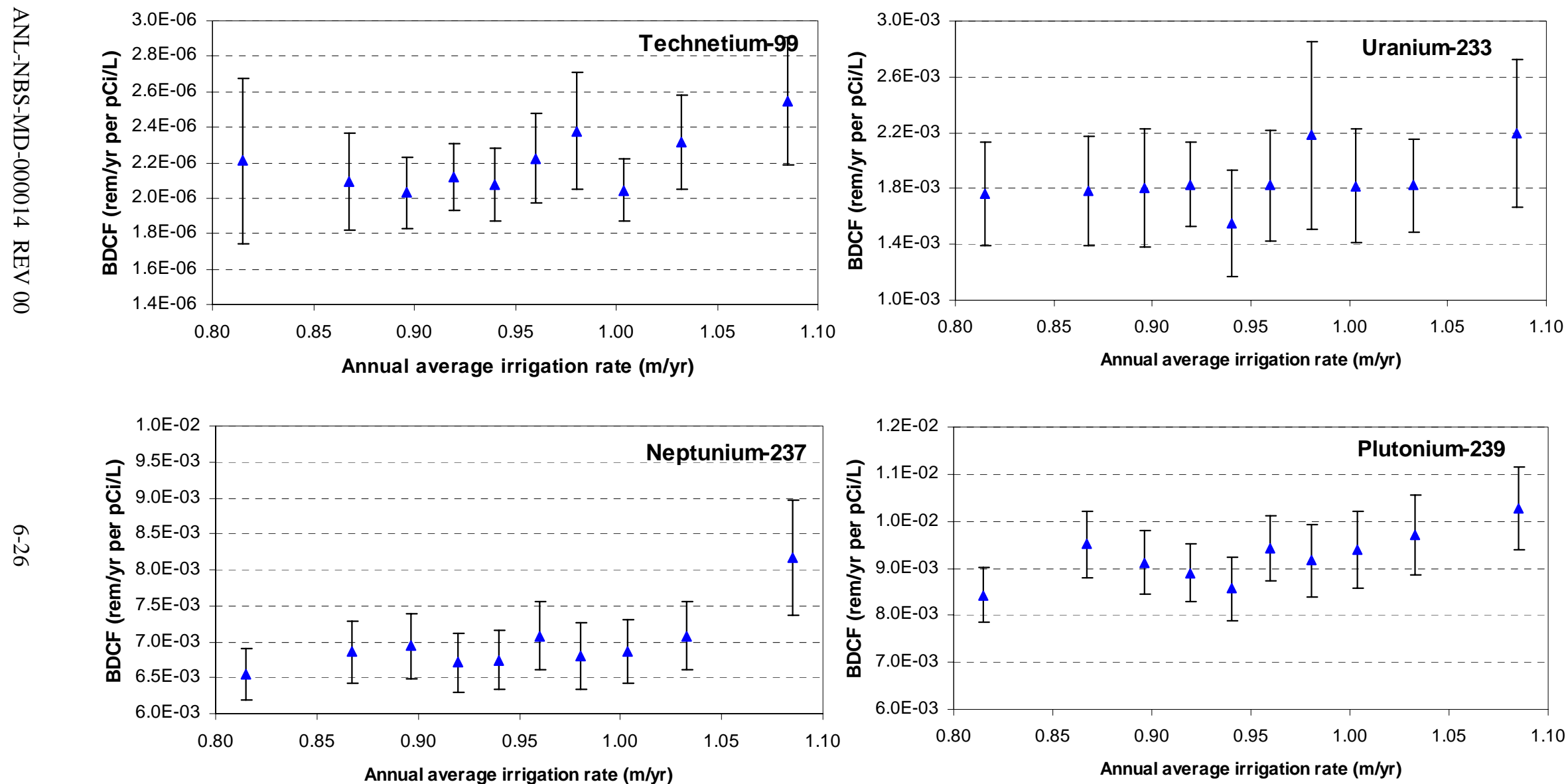

Source: Excel file Dependence of GW BDCFs on Inputs.xIs (Appendix A).

NOTE: The triangles represent the mean of 100 values. The error bars represent the uncertainty range for the mean at the 95 percent uncertainty interval, calculated as 1.96 times the standard error of the mean. The outlier point with a high BDCF value for ${ }^{99}$ Tc was removed to better show the trend in the BDCFs for this radionuclide as a function of the irrigation rate.

Figure 6.2-8. Dependence of BDCF for the Groundwater Exposure Scenario and Present-Day Climate on Annual Average Irrigation Rate 
The graphs in Figure 6.2-8 show that there is a positive relationship between BDCFs and irrigation rate in the upper part of the range of irrigation rates used in the model (annual average irrigation rate greater than about $1 \mathrm{~m} / \mathrm{yr}$ ). This dependence is stronger for the radionuclides that strongly adsorb to soil particles (i.e., have high $\mathrm{K}_{\mathrm{d}}$ values), such as ${ }^{237} \mathrm{~Np}$ and ${ }^{239} \mathrm{Pu}$. For these radionuclides, the difference between the average BDCF value using the minimum of the irrigation rate range and the BDCF value calculated using the maximum was assessed in deterministic runs of the biosphere model. The input parameter values used in the model were presented in Tables 4.1-1 to 4.1-4. For the stochastic model parameters, these values are either the distribution means or the values that best represent a distribution, such as the mode. The results are summarized in Table 6.2-7.

Table 6.2-7. BDCF and Percent Change from Average for Different Levels of Annual Average Irrigation Rate

\begin{tabular}{|l|c|c|c|c|c|}
\hline \multirow{2}{*}{$\begin{array}{c}\text { Irrigation } \\
\text { Conditions }\end{array}$} & Irrigation, m/yr & BDCF & $\begin{array}{c}\text { Percent Change } \\
\text { from Average }\end{array}$ & \multicolumn{2}{c|}{ Plutonium-239 } \\
\cline { 2 - 6 } & BDCF & $\begin{array}{c}\text { Percent Change } \\
\text { from Average }\end{array}$ \\
\hline Average & 0.95 & $5.35 \mathrm{E}-03$ & N/A & $7.68 \mathrm{E}-03$ & N/A \\
\hline Minimum & 0.74 & $5.12 \mathrm{E}-03$ & -4.2 & $6.75 \mathrm{E}-03$ & -12.1 \\
\hline Maximum & 1.16 & $5.58 \mathrm{E}-03$ & 4.2 & $8.61 \mathrm{E}-03$ & 12.1 \\
\hline Alfalfa & 1.94 & $6.42 \mathrm{E}-03$ & 19.9 & $1.21 \mathrm{E}-02$ & 57.0 \\
\hline
\end{tabular}

NOTE: BDCFs were calculated in deterministic runs of ERMYN_GW_MC8_Det_Base.gsm by changing the radionuclide selection and the value of annual average irrigation rate. The percent change for the BDCFs was calculated in the Excel spreadsheet Dependence of GW BDCFs on Inputs.xIs (Appendix A).

The results of the BDCF calculations using different irrigation rates indicate that the BDCFs for ${ }^{237} \mathrm{~Np}$ are relatively insensitive to the value of the annual average irrigation rate and that the value varies by only about \pm 4 percent over the variability range of this parameter. If a higher value of the irrigation rate is used, which is typical of alfalfa, the BDCF for ${ }^{237} \mathrm{~Np}$ is about 20 percent greater than the average. For ${ }^{239} \mathrm{Pu}$, the differences are greater: about \pm 12 percent over the variability range and up to 57 percent higher for the irrigation rate of alfalfa.

Offsetting radionuclide addition from irrigation are the processes that remove radionuclides from surface soil. These processes are collectively represented in the model by the effective removal constant in Equation 6.2-2. The biosphere model includes removal of radionuclides from surface soil by radioactive decay, leaching to the deep soil, and soil erosion.

The surface soil erosion removal constant, $\lambda_{e}$, represents the rate of radionuclide loss from the surface soil due to wind (dominant for the present-day climate) as well as surface erosion from occasional heavy precipitation (an important contributor to erosion in the future climate). This parameter is calculated in the biosphere model (BSC 2004 [DIRS 169460], Equation 6.4.1-11) using the annual average erosion rate for the surface soil, representing the removal of soil mass per unit area per unit time, and the surface soil depth and density. The value of annual average erosion rate is a radionuclide-independent parameter that is strongly site-specific and depends on environmental characteristics and land use. The range of the soil erosion rate is from 0.19 to $1.1 \mathrm{~kg} /\left(\mathrm{m}^{2} \mathrm{yr}\right)$, which, when divided by the density of surface soil (65 to $\left.510 \mathrm{~kg} / \mathrm{m}^{2}\right)$, gives the erosion rate constant range from about 0.0004 to about 0.017 per year (from the modeling results included in the Excel file Dependence of $G W B D C F$ s on Inputs.xls, Appendix A). The soil 
erosion rate was developed from the information include in the U.S. Department of Agriculture Natural Resources Conservation Service database and from other literature sources. The values were selected such that they are representative of the types of soils, climate, and land use conditions in Amargosa Valley (BSC 2004 [DIRS 169459]).

To illustrate the dependence of BDCFs on the values of erosion rate, graphs were produced, similar to those shown in Figure 6.2-8 for irrigation rates. These graphs show the BDCF dependence on the value of erosion rate used in the biosphere model for ${ }^{99} \mathrm{Tc},{ }^{233} \mathrm{U},{ }^{237} \mathrm{~Np}$, and ${ }^{239} \mathrm{Pu}$. The graphs were plotted using averaged values of the independent and dependent variables in blocks of 100 data pairs, as explained before, and are shown in Figure 6.2-9.

A few observations can be made based on Figure 6.2-9. First, the BDCFs for ${ }^{99} \mathrm{Tc}$ are independent of erosion rate. This is because technetium is an element that has a relatively low $\mathrm{K}_{\mathrm{d}}$ and thus leaching is a much more important radionuclide removal mechanism than soil erosion. Second, soil erosion is important for those radionuclides that have a moderate ${ }^{233} \mathrm{U}$ and ${ }^{237} \mathrm{~Np}$ ) and high value of $\mathrm{K}_{\mathrm{d}}\left({ }^{239} \mathrm{Pu}\right)$. For these radionuclides, a strong dependence on the erosion rate can be observed, especially in the lower region of the parameter range. In this region of the parameter range, the effectiveness of soil erosion as a mechanism of radionuclide removal from surface soil is diminished and radionuclides build up in surface soil. For the higher erosion rate, the BDCFs for these radionuclides seem to asymptotically converge to a constant BDCF value, which is consistent with the functional relationship of the equilibrium activity concentration in the soil and the erosion rate constant, which is of the $f(x)=\frac{1}{x}$ type. In this region, the removal processes effectively reduce the activity concentration in the soil and the BDCF is controlled by other pathways that are not related to radionuclide concentration in the surface soil, such as consumption of water, or ingestion of crops contaminated by deposition of water on the foliage. In fact, for the highly sorbing radionuclides, their uptake by crops from soil is a less important mechanism than the radionuclide deposition on plant surfaces from irrigation as discussed in Section 6.2.4.3. 

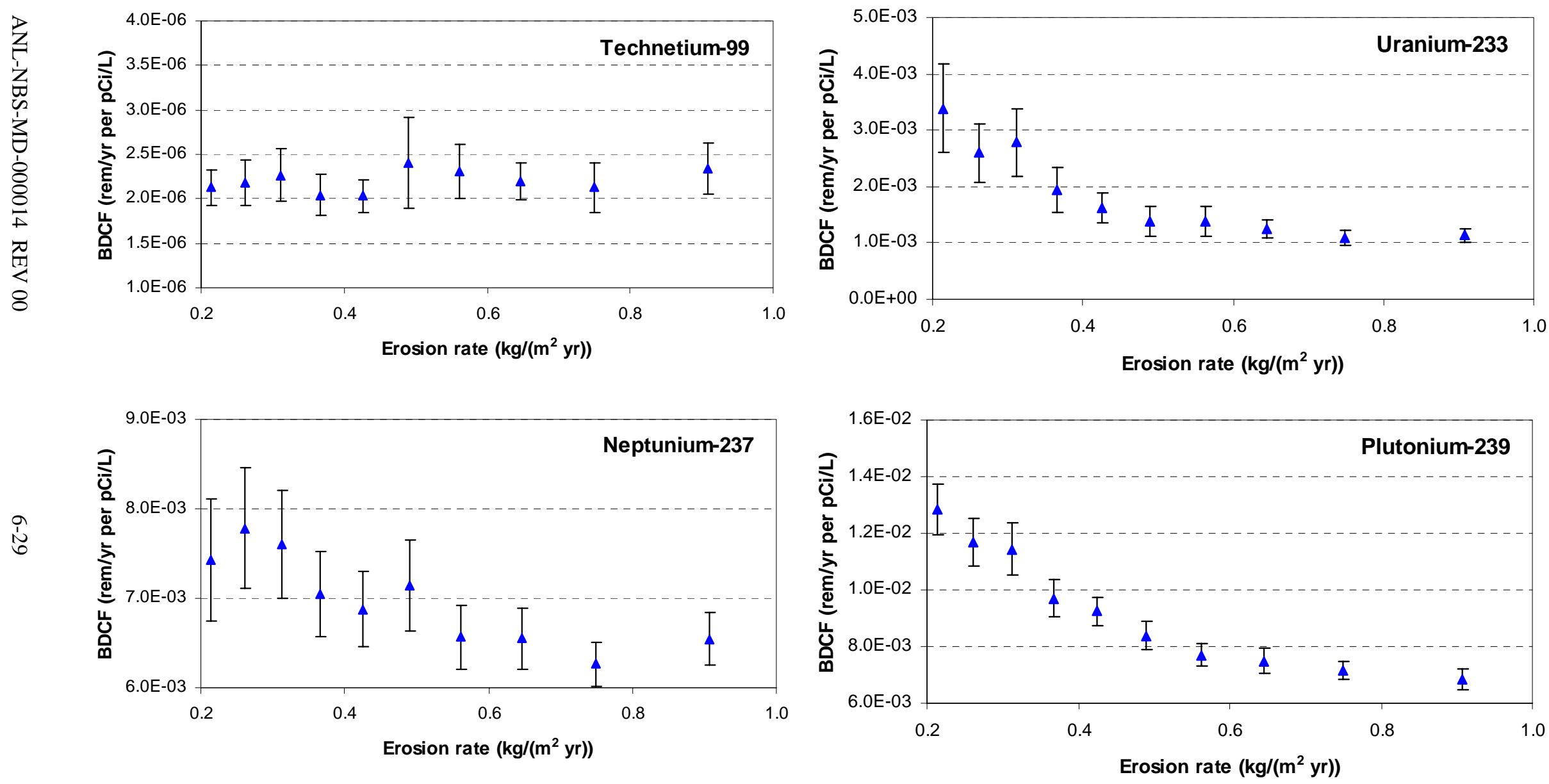

Source: Excel file Dependence of GW BDCFs on Inputs.xIs (Appendix A).

NOTE: The triangles represent the mean of 100 values. The error bars represent the uncertainty range for the mean at the 95 percent uncertainty interval, calculated as 1.96 times the standard error of the mean. The outlier point with a high BDCF value for ${ }^{99}$ Tc was removed to better show the trend in the BDCFs for this radionuclide as a function of the erosion rate. 
Another process that results in radionuclide removal from surface soil is leaching. The process of leaching radionuclides from the surface soil is evaluated using element-specific leaching removal constants (BSC 2004 [DIRS 169460], Section 6.4.1.3). The leaching removal constant for each radionuclide $\left(\lambda_{l}\right)$ is calculated using a relationship (adopted from BSC 2004 [DIRS 169460], Equation 6.4.1-10)

$$
\lambda_{l}=\frac{O W}{d \times \theta\left(1+\frac{\rho}{\theta} K_{d}\right)}
$$

where

$$
\begin{aligned}
O W= & \text { crop overwatering rate }(\mathrm{m} / \mathrm{yr}) \\
d= & \text { depth of surface soil }(\mathrm{m}) \\
\rho= & \text { bulk density of surface soil }\left(\mathrm{kg} / \mathrm{m}^{3}\right) \\
\theta= & \text { volumetric water content of soil (dimensionless) } \\
K_{d}= & \text { solid-liquid partition coefficient for the radionuclide in surface soil } \\
& (\mathrm{Bq} / \mathrm{kg} \text { solid }) /\left(\mathrm{Bq} / \mathrm{m}^{3} \text { liquid }\right)=\left(\mathrm{m}^{3}{ }_{\text {liquid }} / \mathrm{kg}_{\text {solid }}\right)
\end{aligned}
$$

The value of the leaching removal constant is influenced by the overwatering rate, OW, soil-liquid partition coefficient, $\mathrm{K}_{\mathrm{d}}$, and other parameters that characterize soil properties. Soil-specific parameters were taken from the U.S. Department of Agriculture Natural Resources Conservation Service database and from other literature sources. The values were selected such that they are representative of the types of soils, climate, and land use conditions in Amargosa Valley (BSC 2004 [DIRS 169459], Section 4.1). The volumetric water content of soil is defined as the fraction of the soil volume representing water-filled porosity. The value of this parameter depends on soil texture and ranges from less than 0.1 (dry soils) to between 0.4 and 0.5 (water-saturated soils) for the soil types in Amargosa Valley, with typical values of about 0.2 to 0.3 .

The value of the overwatering rate was developed for representative crops based on the crop leaching fraction (the amount of water applied in addition to crop water requirements to remove excess salts from the root zone) or the deep percolation of precipitation below the crop root zone. As shown in Table 6.2-3, the overwatering rate has a high correlation coefficient with BDCFs for most radionuclides. In arid regions, the overwatering rate usually is determined by calculating the amount of water required to transport accumulated salts out of the surface soil to maintain productivity. The value of this parameter is on the order of $10 \mathrm{~cm} / \mathrm{yr}$ (BSC 2004 [DIRS 169673], Section 6.9).

The dependence of BDCFs for selected radionuclides on the value of the overwatering rate is shown in Figure 6.2-10 (see Excel file Dependence of $G W$ BDCFs on Inputs.xls, Appendix A). It can be seen that the BDCFs decrease as overwatering increases for all radionuclides. This is because overwatering causes leaching of radionuclides out of the surface soil thus decreasing the level of equilibrium radionuclide concentration in the soil. Decreased activity concentration in the soil results in less activity available for plant root uptake and leads to a reduced ingestion dose as well as reduced inhalation and external exposures. The strength of the correlation with the overwatering rate can be seen by the range of the error bars for the radionuclides shown in Figure 6.2-10. 

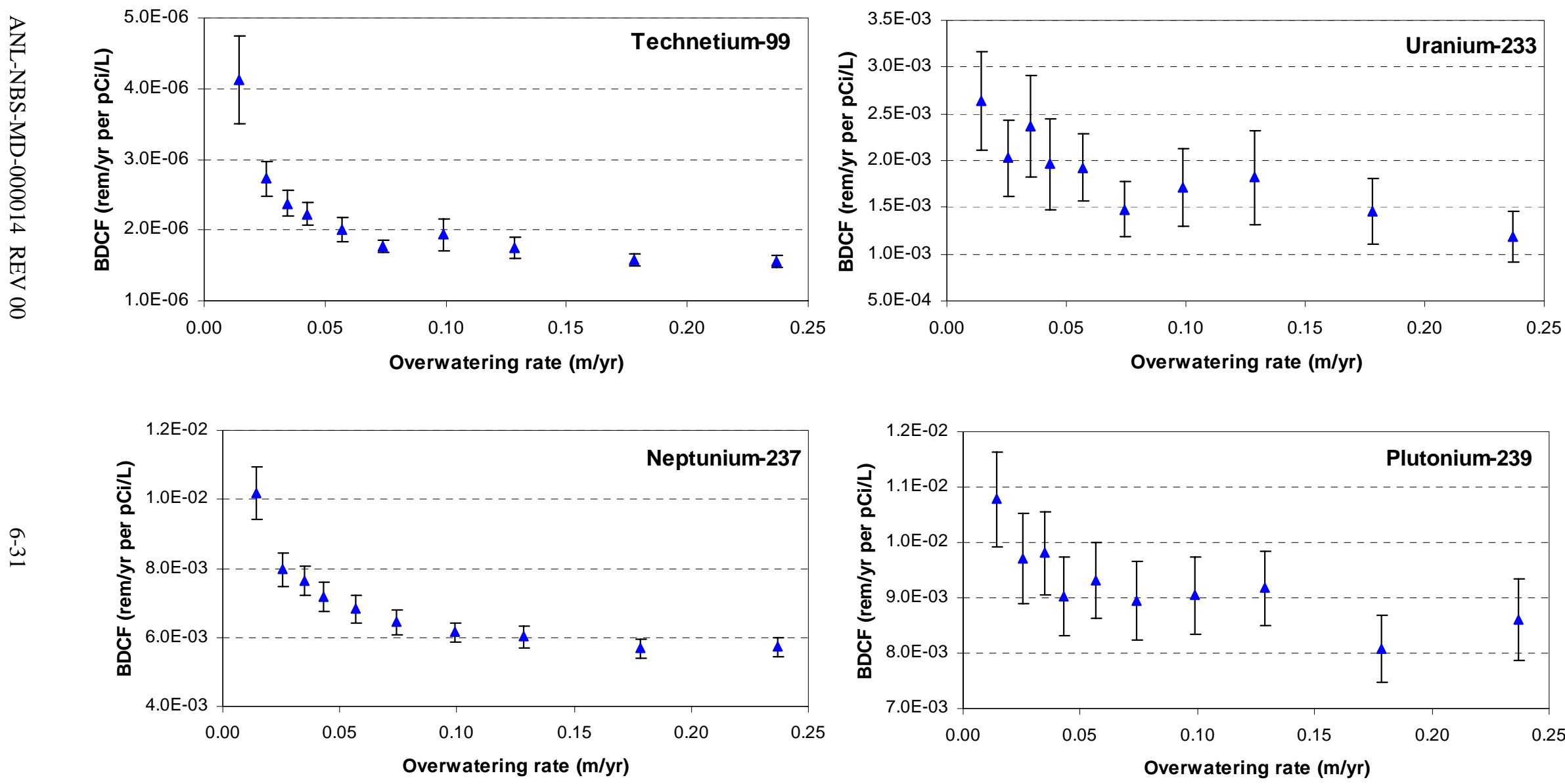

Source: Excel file Dependence of GW BDCFs on Inputs.xIs (Appendix A).

NOTE: The triangles represent the mean of 100 values. The error bars represent the uncertainty range for the mean at the 95 percent uncertainty interval, calculated as 1.96 times the standard error of the mean. The outlier point with a high BDCF value for ${ }^{99}$ Tc was removed to better show the trend in the BDCFs for this radionuclide as a function of the overwatering rate.

Figure 6.2-10. Dependence of BDCF for the Groundwater Exposure Scenario and Present-Day Climate on Overwatering Rate 
The leaching removal constant also depends on the value of $K_{d}$. The $K_{d} s$, in turn, depend on soil characteristics, with values spanning several orders of magnitude (with geometric means from $0.14 \mathrm{~L} / \mathrm{kg}$ for technetium to $3.6 \times 10^{4} \mathrm{~L} / \mathrm{kg}$ for radium) (BSC 2004 [DIRS 169459], Section 7.1.2). The overall uncertainty in the $K_{d}$ values is the greatest of all biosphere model parameters. To illustrate the overall effect of the uncertainty in the $K_{d}$ values on the biosphere modeling results, plots were generated that show the dependence of BDCFs on $\mathrm{K}_{\mathrm{d}}$ values. The plots (Figure 6.2-11) were constructed for the same four radionuclides as for the preceding plots. These radionuclides represent distributions with high $\left({ }^{239} \mathrm{Pu}\right)$, moderate $\left({ }^{237} \mathrm{~Np}\right.$ and $\left.{ }^{233} \mathrm{U}\right)$, and low $\left({ }^{99} \mathrm{Tc}\right)$ mean values of $\mathrm{K}_{\mathrm{d}} \mathrm{S}$.

Figure 6.2-11 shows that although the range of $K_{d}$ values covers several orders of magnitude, the impact of these large changes in $K_{d}$ values on BDCF values is less than a factor of 2 about the mean value for most radionuclides. For ${ }^{237} \mathrm{~Np}$ and ${ }^{233} \mathrm{U}$, elements with a moderate value of $\mathrm{K}_{\mathrm{d}}$, there is little change in BDCF values for $K_{d}$ values at the low end of the range. In this region, leaching is efficient and little buildup is expected. At higher $K_{d}$ values, the BDCFs increase due to radionuclide retention in the soil. BDCF values for a radionuclide with a high $\mathrm{K}_{\mathrm{d}}\left({ }^{239} \mathrm{Pu}\right)$ gradually increases as $K_{d}$ increases (due to low leaching and thus greater buildup in soil), but converge to a fixed value at high $\mathrm{K}_{\mathrm{d}}$ values. In this region of high $\mathrm{K}_{\mathrm{d}}$ values, BDCFs no longer increase as $\mathrm{K}_{\mathrm{d}} \mathrm{S}$ increase because the equilibrium radionuclide concentration in surface soil is controlled by soil erosion.

Technetium has the lowest mean $K_{d}$ of those considered for TSPA (a geometric mean of $0.14 \mathrm{~L} / \mathrm{kg}$ compared to the next lowest of $4.5 \mathrm{~L} / \mathrm{kg}$ for iodine). The BDCFs for ${ }^{99} \mathrm{Tc}$ show the effect of increased plant uptake at low $\mathrm{K}_{\mathrm{d}}$ values resulting from the inverse correlation between the soil-to-plant transfer factor and $\mathrm{K}_{\mathrm{d}}$ (Figure 6.2-11). For a low $\mathrm{K}_{\mathrm{d}}$, leaching is an efficient radionuclide removal mechanism keeping the equilibrium concentration of this element in surface soil at a relatively low level, but, for such low $\mathrm{K}_{\mathrm{d}}$ values, increased plant uptake due to availability of the radionuclide in the solution drives the BDCF to higher values. As the $\mathrm{K}_{\mathrm{d}}$ increases, the BDCF passes through a minimum and, for the $\mathrm{K}_{d} \mathrm{~S}$ in the upper region of their range, increases as leaching becomes less efficient as a removal mechanism. This process causes increased radionuclide buildup in surface soil and, consequently, causes an increase in the BDCF components that depend on radionuclide concentration in the soil. The range of the $\mathrm{K}_{\mathrm{d}}$ values was selected such that it encompasses all values reported in the literature. Therefore, it is unlikely that additional data on $\mathrm{K}_{\mathrm{d}}$ would result in higher BDCF values. For the higher $\mathrm{K}_{\mathrm{d}}$ values, the BDCFs reach an asymptote, as shown in Figure 6.2-11 graphs for ${ }^{233} \mathrm{U}$ and ${ }^{239} \mathrm{Pu}$; in this range of $K_{d}$ values, soil erosion controls the level of equilibrium concentration in surface soil.

The relative insensitivity of the BDCF value to order-of-magnitude changes in the $\mathrm{K}_{\mathrm{d}}$ value, along with the conservative approach of using the equilibrium radionuclide concentration in the soil, adds confidence that the selection of the $K_{d}$ values for the biosphere model is justified, and that additional data on $\mathrm{K}_{\mathrm{d}}$ values in Amargosa Valley would not invalidate biosphere modeling results or affect the sensitivity of those results to the parameter values. 

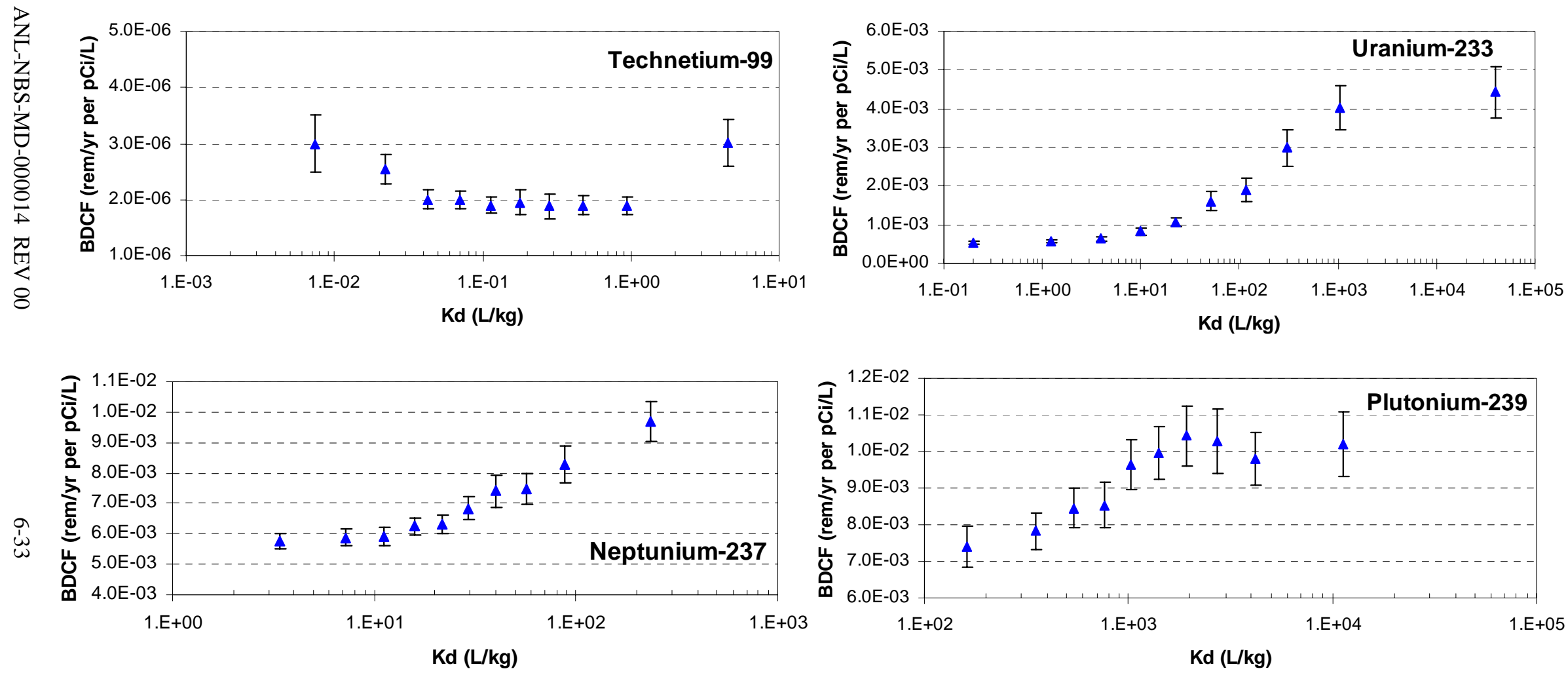

Source: Excel file Dependence of GW BDCFs on Inputs.xIs (Appendix A).

NOTE: The triangles represent the mean of 100 values. The error bars represent the uncertainty range for the mean at the 95 percent uncertainty interval, calculated as 1.96 times the standard error of the mean. The outlier point with a high BDCF value for ${ }^{99} \mathrm{Tc}$ was removed to better show the trend in the BDCFs for this radionuclide as a function of the $\mathrm{K}_{\mathrm{d}}$.

Figure 6.2-11. Dependence of BDCF for the Groundwater Exposure Scenario and Present-Day Climate on $\mathrm{K}_{d} \mathrm{~S}$ 


\subsubsection{Radionuclide Transport to Air}

Radionuclides transported to the atmosphere originate in two environmental media: water and soil. Radionuclide transport from water to air is only considered in the case of aerosols generated by operation of evaporative coolers. Radionuclide transport from soil to air occurs via resuspension of surface soil and exhalation of gasses from the soil.

\subsection{Operation of Evaporative Coolers}

Inhalation of particulate matter and inhalation of aerosols generated by evaporative coolers are important pathways for actinides (see Tables 6.2-1 and 6.2-2), the latter depending on climate conditions. Inhalation of aerosols generated by evaporative cooler contributes on average from 0 to 43 percent for the present-day climate BDCFs and from 0 to about 16 percent for the future climate BDCFs for the groundwater exposure scenario, depending on a radionuclide.

Radionuclide concentration in indoor air when evaporative coolers are in operation is calculated in the biosphere model as (based on BSC 2004 [DIRS 169460], Equation 6.4.2-3)

$$
C a_{e}=f_{\text {evap }} \frac{M_{\text {water }}}{F_{\text {air }}} C w
$$

where

$\mathrm{Ca}_{e}=$ activity concentration of a radionuclide in the air resulting from the operation of an evaporative cooler $\left(\mathrm{Bq} / \mathrm{m}^{3}\right)$

$f_{\text {evap }}=$ fraction of radionuclides in water transferred to indoor air (dimensionless)

$M_{\text {water }}=$ water evaporation rate (water use rate) for an evaporative cooler $\left(\mathrm{m}^{3} / \mathrm{hr}\right.$ )

$F_{\text {air }} \quad=$ air flow rate for an evaporative cooler $\left(\mathrm{m}^{3} / \mathrm{hr}\right)$

$\mathrm{Cw}=$ activity concentration of the radionuclide in the groundwater $\left(\mathrm{Bq} / \mathrm{m}^{3}\right)$.

The parameters in Equation 6.2-4 that are related to evaporative cooler operation, such as the water use rate and the air flow rate, were developed based on the technical specifications of evaporative coolers that would be suitable for the type of houses in Amargosa Valley. A search of the scientific literature did not find environmental assessments that considered the evaporative cooler transport process, so there is a lack of experimental measurements of the transfer of radionuclides from water to air. Therefore, a maximum range from zero to unity was used in the model. This was done to evaluate the importance of this parameter in the biosphere model and to determine if a further investigation leading to a more accurate value was warranted.

The dependence of BDCFs on the value of the water transfer fraction for evaporative coolers is shown in Figures 6.2-12 and 6.2-13 for the present-day and future climates, respectively for ${ }^{99} \mathrm{Tc}$, ${ }^{233} \mathrm{U},{ }^{237} \mathrm{~Np}$, and ${ }^{239} \mathrm{Pu}$. As can be seen, this parameter does not have a strong influence on the BDCF values. Changing the water transfer fraction from a mean of 0.5 to a minimum of zero or a maximum of one causes a change of less than 15 percent in the BDCF for ${ }^{237} \mathrm{~Np}$ for the present day climate. These results were obtained from deterministic runs of the model. The BDCF values were $4.57 \times 10^{-3}, 5.35 \times 10^{-3}$, and $6.13 \times 10^{-3} \mathrm{rem} / \mathrm{yr}$ per $\mathrm{pCi} / \mathrm{L}$, for $f_{\text {evap }}=0,0.5$, and 1 , respectively. 

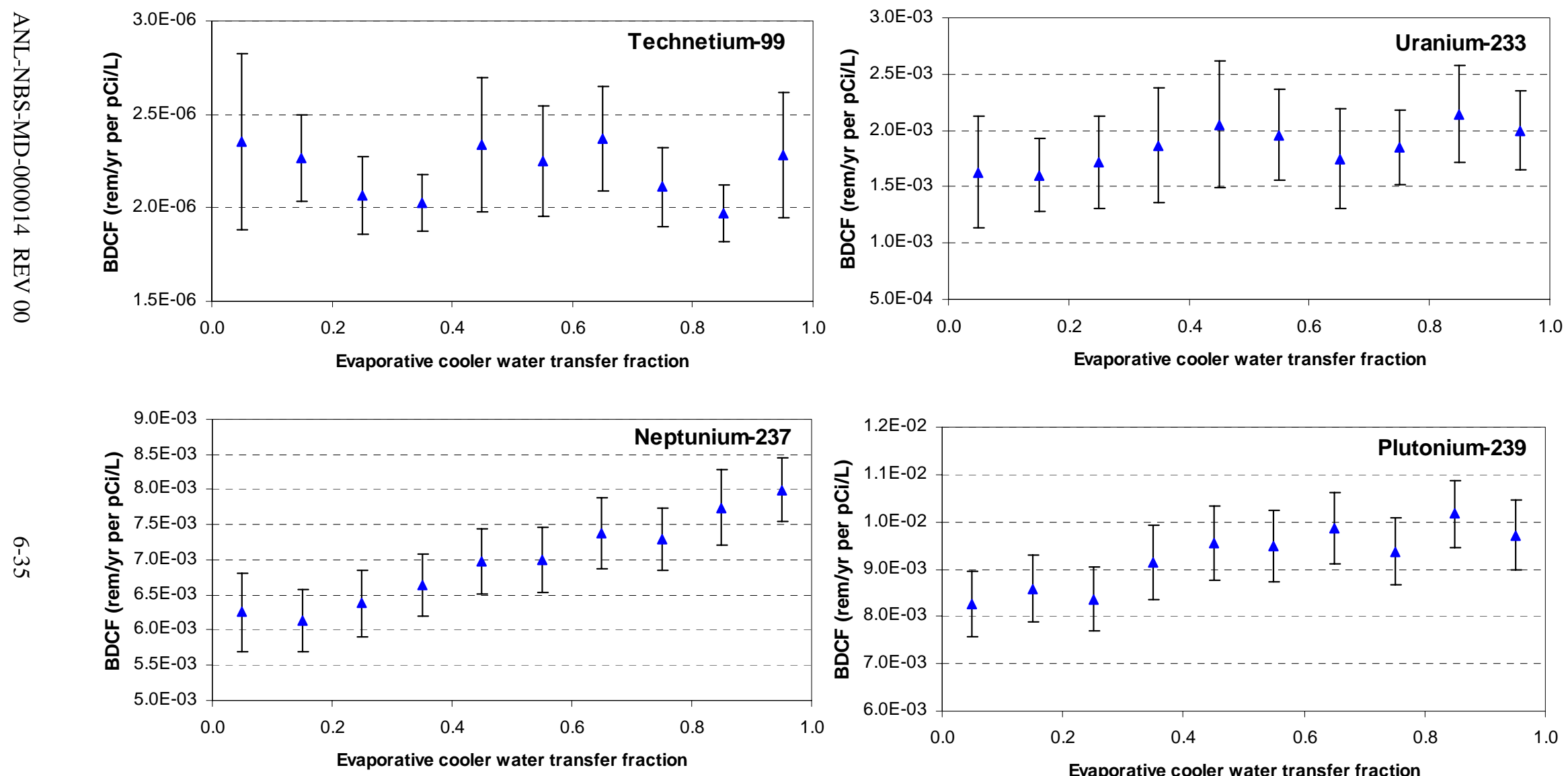

Source: Excel file Dependence of GW BDCFs on Inputs.xIs (Appendix A).

NOTE: The triangles represent the mean of 100 values. The error bars represent the uncertainty range for the mean at the 95 percent uncertainty interval, calculated as 1.96 times the standard error of the mean. The outlier point with a high BDCF value for ${ }^{99} \mathrm{Tc}$ was removed to better show the trend in the BDCFs for this radionuclide as a function of the evaporative cooler water transfer fraction.

Figure 6.2-12. Dependence of BDCF for the Groundwater Exposure Scenario and the Present-Day Climate on the Water Transfer Fraction for Evaporative Coolers 

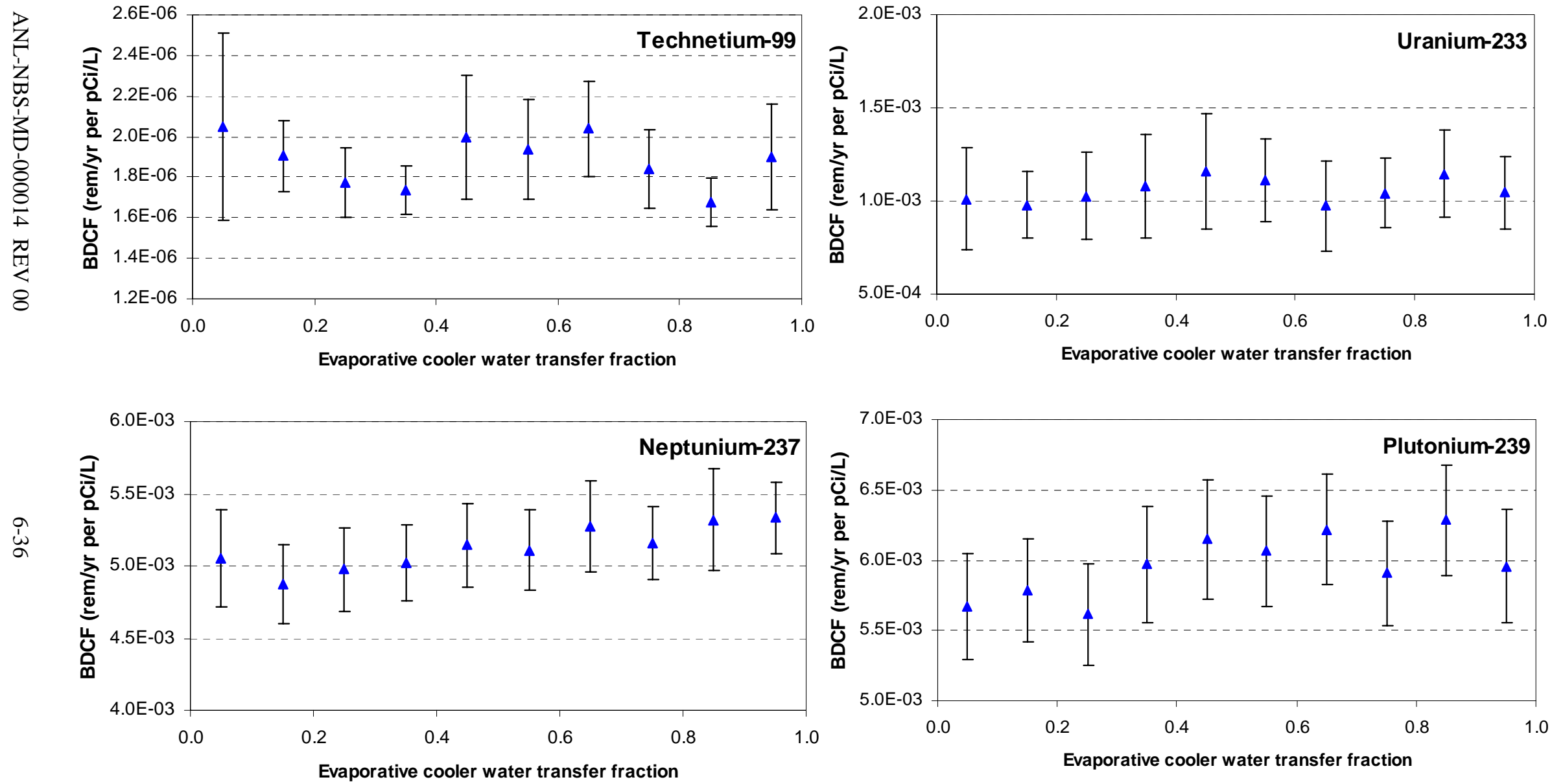

Source: Excel file Dependence of GW BDCFs on Inputs.xls (Appendix A).

NOTE: The triangles represent the mean of 100 values. The error bars represent the uncertainty range for the mean at the 95 percent uncertainty interval, calculated as 1.96 times the standard error of the mean. The outlier point with a high BDCF value for ${ }^{99} \mathrm{Tc}$ was removed to better show the trend in the BDCFs for this radionuclide as a function of the evaporative cooler water transfer fraction.

Figure 6.2-13. Dependence of BDCF for the Groundwater Exposure Scenario and the Future Climate on the Water Transfer Fraction for Evaporative Coolers 
The difference between the mean BDCF value obtained in a deterministic run and the mean of the BDCF distribution from a stochastic realization of the model results from the selection of representative (fixed) input parameter values for the deterministic runs. Some of these representative values are not the mean of the distribution used in the stochastic realizations.

The importance of the evaporative cooler pathway decreases for the future climate, which is expected to be cooler and wetter than the present-day climate. The present-day climate is predicted to last for only 400-600 years post-closure followed by the monsoon and the glacial transition climate (BSC 2004 [DIRS 170002], Table 6-1).

The increase in the mean BDCF of ${ }^{237} \mathrm{~Np}$ as the results of the evaporative cooler water transfer fraction change from $f_{\text {evap }}=0$ to $f_{\text {evap }}=1$ is about 35 percent for the present-day climate and still less for the future climate. Considering that the upper bound of the BDCF range for ${ }^{237} \mathrm{~Np}$ differs from the lower bound by a factor of nearly 7, the uncertainty introduced by the evaporative cooler component is not significant.

The influence of activity concentration in air caused by the operation of evaporative coolers on BDCFs for five radionuclides was estimated in a series of deterministic model runs. The calculations were done for the average value of activity concentration in indoor air from operation of evaporative coolers and for twice that value. The results are presented in Table 6.2-8.

Table 6.2-8. BDCFs and Percent Change for a Doubling in the Average Activity Concentration in Air from Operation of Evaporative Coolers

\begin{tabular}{|c|c|c|c|c|}
\hline \multirow[b]{2}{*}{ Radionuclide } & \multicolumn{2}{|c|}{ Activity Concentration in Air } & \multirow{2}{*}{$\begin{array}{c}\text { BDCF } \\
\text { rem/yr per pCi/L }\end{array}$} & \multirow{2}{*}{$\begin{array}{c}\text { Percent Change } \\
\text { Relative to Average }\end{array}$} \\
\hline & Level & $\mathrm{Bq} / \mathrm{m}^{3}$ & & \\
\hline \multirow[t]{2}{*}{ Technetium-99 } & Average & $1.024 \mathrm{E}-06$ & 1.380E-06 & \\
\hline & $2 \times$ Average & $2.048 \mathrm{E}-06$ & $1.392 \mathrm{E}-06$ & 0.9 \\
\hline \multirow[t]{2}{*}{ lodine-129 } & Average & $1.024 \mathrm{E}-06$ & $2.588 \mathrm{E}-04$ & \\
\hline & $2 \times$ Average & 2.048E-06 & $2.591 \mathrm{E}-04$ & 0.1 \\
\hline \multirow[t]{2}{*}{ Uranium-233 } & Average & $1.024 \mathrm{E}-06$ & $9.529 \mathrm{E}-04$ & \\
\hline & $2 \times$ Average & 2.048E-06 & 1.149E-03 & 20.6 \\
\hline \multirow[t]{2}{*}{ Neptunium-237 } & Average & $1.024 \mathrm{E}-06$ & 5.350E-03 & \\
\hline & $2 \times$ Average & $2.048 \mathrm{E}-06$ & $6.132 \mathrm{E}-03$ & 14.6 \\
\hline \multirow[t]{2}{*}{ Plutonium-239 } & Average & $1.024 \mathrm{E}-06$ & 7.677E-03 & \\
\hline & $2 \times$ Average & $2.048 \mathrm{E}-06$ & 8.298E-03 & 8.1 \\
\hline
\end{tabular}

NOTE: BDCFs were calculated in deterministic runs of ERMYN_GW_MC8_Det_Base.gsm by changing the radionuclide selection and the value of mass loading. The percent change for the BDCFs was calculated in the Excel spreadsheet Dependence of GW BDCFs on Inputs.xls (Appendix A).

Doubling the activity concentration in air from operation of evaporative coolers results, on average, in an increase in the BDCF from about 21 percent for ${ }^{233} \mathrm{U}$ to less than one percent for ${ }^{99}$ Tc and ${ }^{129} \mathrm{I}$. 


\subsection{Resuspension of Surface Soil}

Radionuclide concentrations in the air from the resuspension of contaminated surface soil are calculated as (BSC 2004 [DIRS 169460], Equation 6.4.2-2)

$$
C a_{h, n}=f_{\text {enhance, } n} C s_{m} S_{n}
$$

where

$$
\begin{aligned}
& \mathrm{Ca}_{h, n}=\text { activity concentration of a radionuclide in the air from soil resuspension for } \\
& \text { the assessment of human inhalation exposure in environment } n\left(\mathrm{~Bq} / \mathrm{m}^{3}\right) \\
& f_{\text {enhance, } n}=\text { enhancement factor for the activity concentration of resuspended particulates } \\
& \text { in environment } n \text { (dimensionless) } \\
& S_{n} \quad=\quad \text { concentration of total resuspended particulates (atmospheric mass loading) } \\
& \text { for evaluation of inhalation exposure for environment } n\left(\mathrm{~kg} / \mathrm{m}^{3}\right) \\
& C s_{m}=\text { mass activity concentration of a radionuclide in soil }(\mathrm{Bq} / \mathrm{kg}) \\
& n \quad=\text { index of the environments (see below) }
\end{aligned}
$$

Five receptor environments associated with different human activities are considered in the biosphere model, four in the contaminated area: active outdoors $(n=1)$, inactive outdoors $(n=2)$, active indoors $(n=3)$, asleep indoors $(n=4)$, and one outside of the contaminated area $(n=5)$ (see BSC 2004 [DIRS 169671], Section 6.2 for detailed discussion of receptor environments). Activity concentration in the air outside the contaminated area is zero. These mutually exclusive environments represent behavioral and environmental combinations for which the receptor would receive a substantially different rate of exposure via inhalation or external exposure.

The average radionuclide concentrations in air in the five environments for ${ }^{99} \mathrm{Tc},{ }^{233} \mathrm{U},{ }^{237} \mathrm{~Np}$, and ${ }^{239} \mathrm{Pu}$ are shown in Figure 6.2-14. The activity concentration in soil for ${ }^{99} \mathrm{Tc}$ is much lower than that for the remaining three radionuclides because ${ }^{99}$ Tc does not build up in surface soil as much as the actinides do. This is due to a higher leaching removal constant for this element. It can also be seen that the radionuclide concentration in air for the active outdoor environment is much higher than that in any of the remaining environments. From Equation 6.2-5, the radionuclide concentration in air depends on the radionuclide concentration in surface soil (discussed in Section 6.2.4.1), atmospheric mass loading, and the enhancement factor. The radionuclide concentration in the outdoor active environment is high because both atmospheric mass loading and the enhancement factor are high for this environment, as shown in Figures 6.2-15 and $6.2-16$, respectively. 


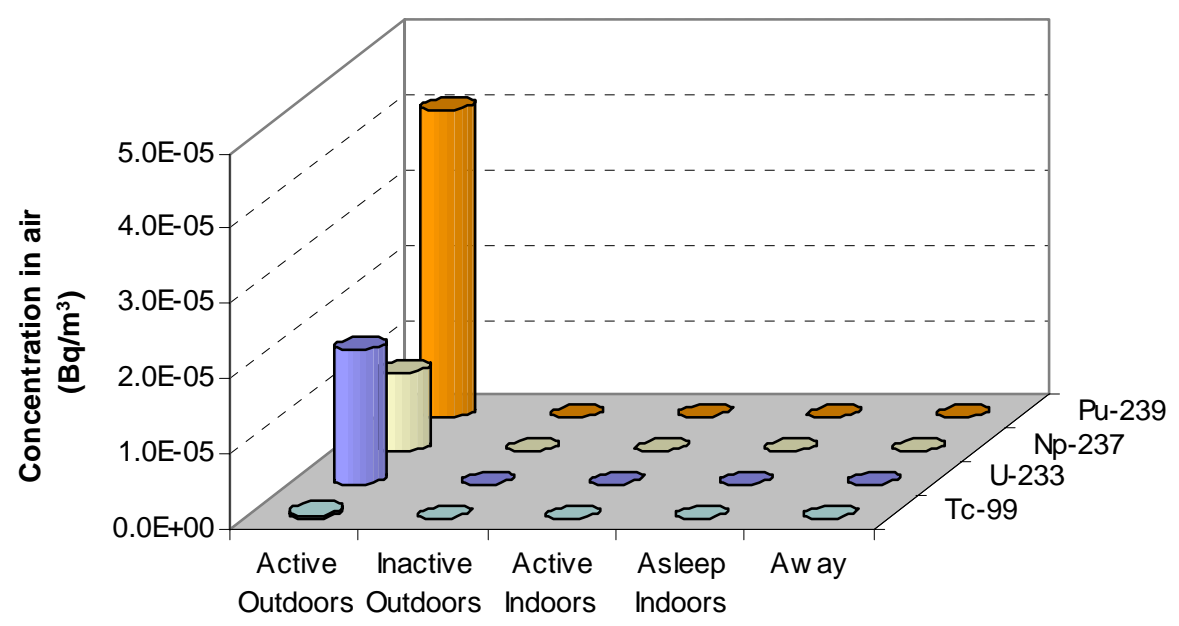

Source: Excel file Detailed Pathway Analysis GW_MC.xIs (Appendix A).

Figure 6.2-14. Average Radionuclide Concentration in Air from Resuspension of Soil by Radionuclide and Environment

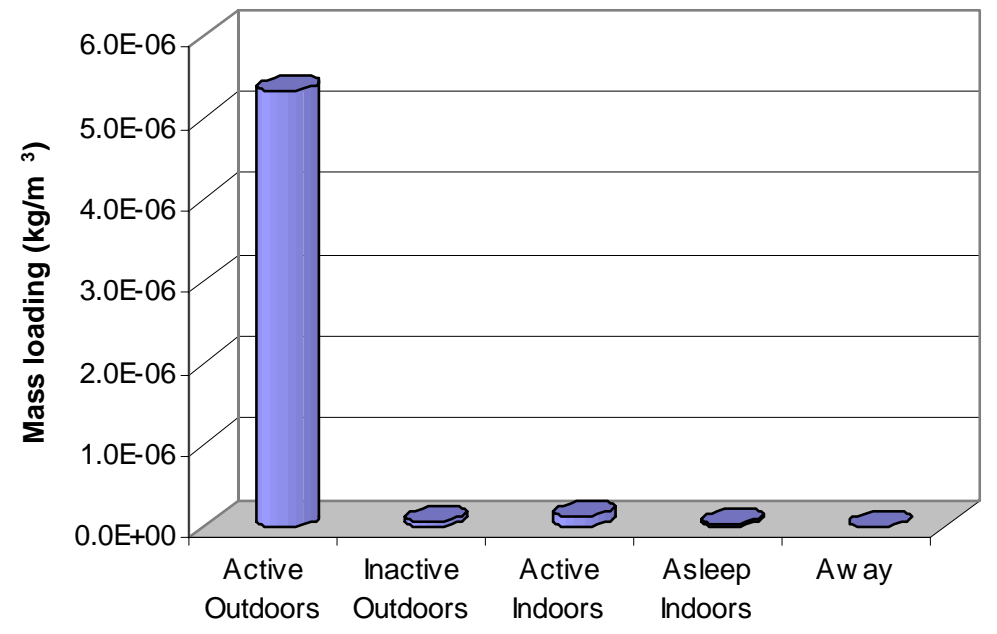

Source: Excel file Detailed Pathway Analysis GW_MC.xls (Appendix A).

Figure 6.2-15. Average Particulate Concentration in Air (Mass Loading) in the Receptor Environments 


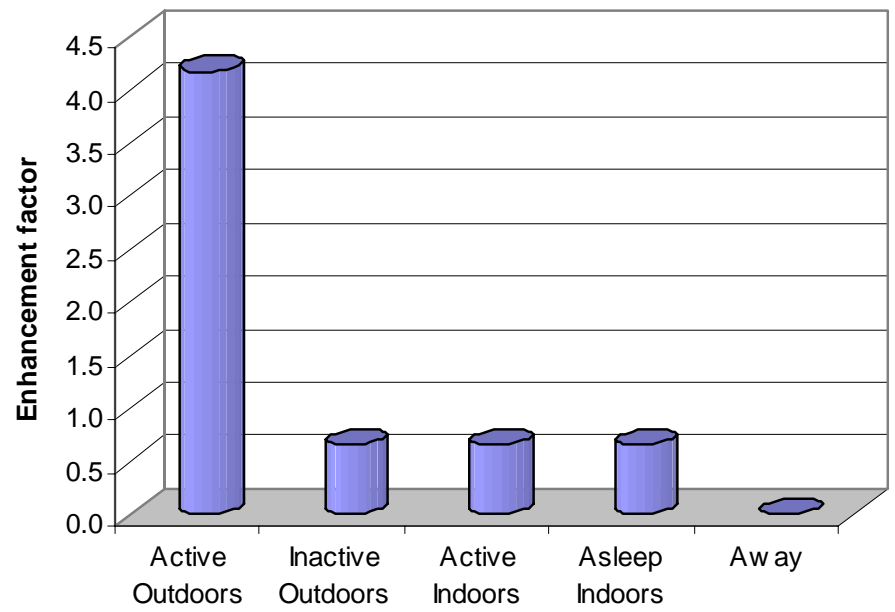

Source: Excel file Detailed Pathway Analysis GW_MC.xIs (Appendix A).

Figure 6.2-16. Average Enhancement Factor in the Receptor Environments

Because mass loading in the outdoor active environment is an important parameter, graphs were produced that show the dependence of the BDCFs on this parameter. The graphs produced for ${ }^{99} \mathrm{Tc},{ }^{233} \mathrm{U},{ }^{237} \mathrm{~Np}$, and ${ }^{239} \mathrm{Pu}$ are shown in Figure 6.2-17. The BDCFs for ${ }^{99} \mathrm{Tc}$ are, as expected, unaffected by mass loading. The BDCFs for the remaining radionuclides depend strongly on mass loading.

The influence of mass loading in the active outdoor environment on the BDCFs for ${ }^{237} \mathrm{~Np}$ and ${ }^{239} \mathrm{Pu}$ was estimated in a series of deterministic model runs. The mass loading parameters used in the runs and the corresponding BDCF values are presented in Table 6.2-9.

Table 6.2-9. BDCF and Percent Change for Different Levels of Mass Loading for the Active Outdoors Environment

\begin{tabular}{|c|c|c|c|c|c|}
\hline \multirow{2}{*}{$\begin{array}{c}\text { Mass Loading } \\
\text { Conditions }\end{array}$} & $\begin{array}{c}\text { Mass Loading } \\
\mathbf{m g} / \mathbf{m}^{\mathbf{3}}\end{array}$ & \multicolumn{2}{|c|}{ Neptunium-237 } & \multicolumn{2}{c|}{ Plutonium-239 } \\
\cline { 3 - 6 } & BDCF & Percent change & BDCF & Percent change \\
\hline Average & 5.00 & $5.35 \mathrm{E}-03$ & N/A & $7.68 \mathrm{E}-03$ & N/A \\
\hline Minimum & 1.00 & $4.76 \mathrm{E}-03$ & -11.0 & $4.68 \mathrm{E}-03$ & -39.0 \\
\hline Maximum & 10.00 & $6.09 \mathrm{E}-03$ & 13.8 & $1.14 \mathrm{E}-02$ & 48.8 \\
\hline
\end{tabular}

NOTE: BDCFs were calculated in deterministic runs of ERMYN_GW_MC8_Det_Base.gsm by changing the radionuclide selection and the value of mass loading. The percent change for the BDCFs was calculated in the Excel spreadsheet Dependence of GW BDCFs on Inputs.xls (Appendix A).

The results of the BDCF calculations using different values of mass loading in the active outdoors environment indicate that the BDCFs for ${ }^{237} \mathrm{~Np}$ are less sensitive to the value of the mass loading than the BDCFs for ${ }^{239} \mathrm{Pu}$. This is because the inhalation of particulate matter is a more important pathway for ${ }^{239} \mathrm{Pu}$ than it is for ${ }^{237} \mathrm{~Np}$. For ${ }^{237} \mathrm{~Np}$ the BDCF value varies by up to about 14 percent over the variability range of this parameter. For ${ }^{239} \mathrm{Pu}$, the difference is greater, up to about 49 percent when the mass loading value is doubled.

For comparison, the dependence of BDCFs for the selected radionuclides on mass loading for the inactive outdoors environment is shown in Figure 6.2-18. 


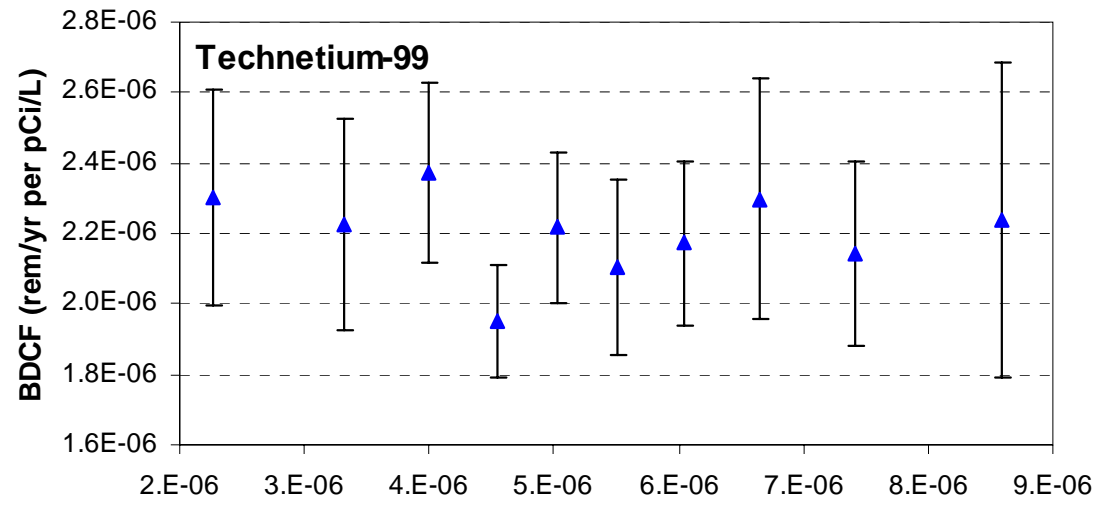

Mass loading, active outdoors environment $\left(\mathrm{kg} / \mathrm{m}^{3}\right)$

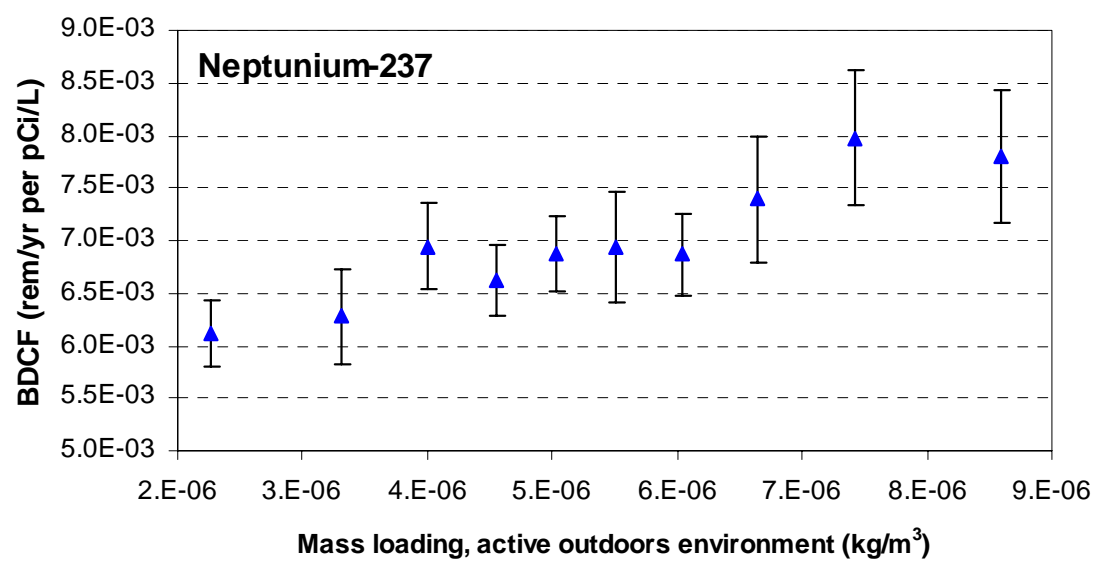

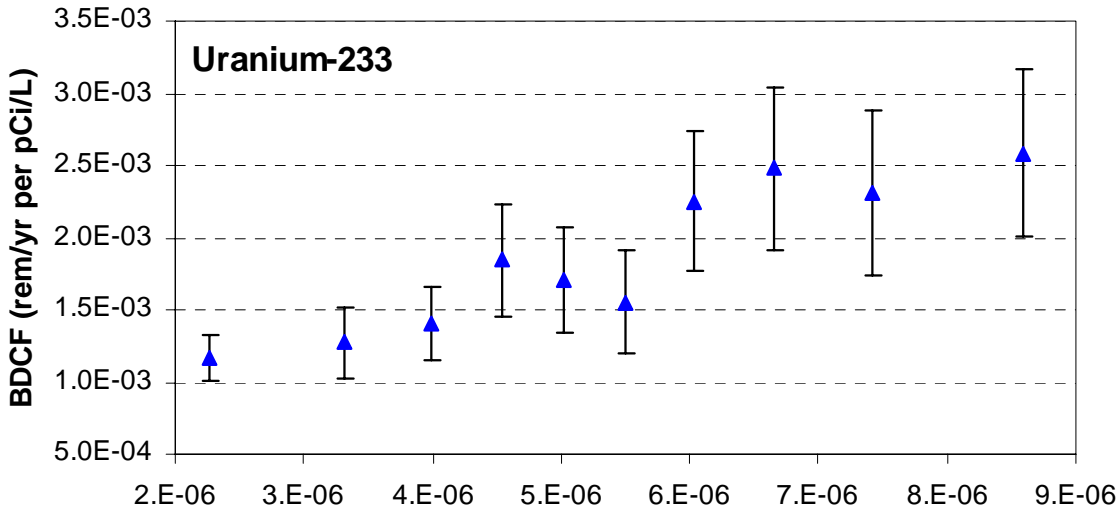

Mass loading, active outdoors environment $\left(\mathrm{kg} / \mathrm{m}^{3}\right)$

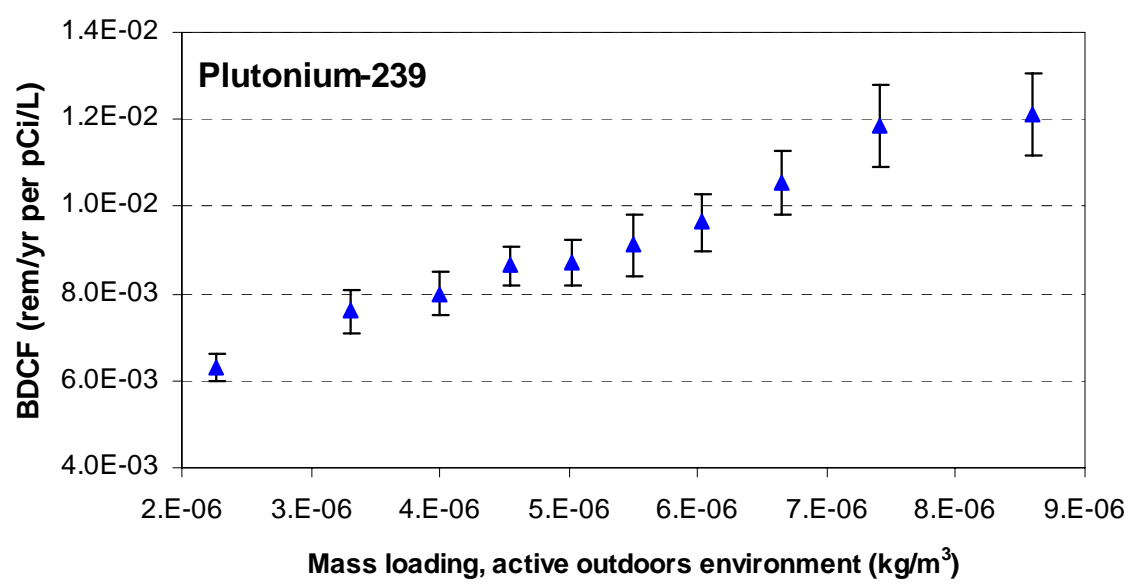

Source: $\quad$ Excel file Dependence of GW BDCFs on Inputs.xls (Appendix A).

NOTE: The triangles represent the mean of 100 values. The error bars represent the uncertainty range for the mean at the 95 percent uncertainty interval, calculated as 1.96 times the standard error of the mean. The outlier point with a high BDCF value for ${ }^{99}$ Tc was removed to better show the trend in the BDCFs for this radionuclide as a function of the mass loading.

Figure 6.2-17. Dependence of BDCF for the Groundwater Exposure Scenario and the Present-Day Climate on the Atmospheric Mass Loading for the Active Outdoors Environment 

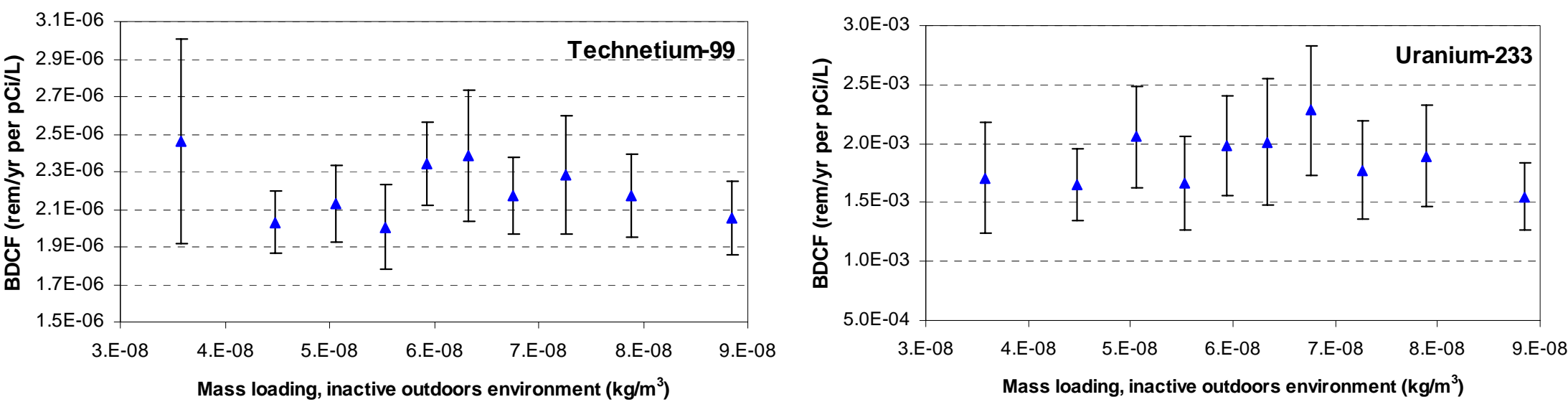

Source: Excel file Dependence of GW BDCFs on Inputs.xls (Appendix A).

NOTE: The triangles represent the mean of 100 values. The error bars represent the uncertainty range for the mean at the 95 percent uncertainty interval, calculated as 1.96 times the standard error of the mean. The outlier point with a high BDCF value for ${ }^{99} \mathrm{Tc}$ was removed to better show the trend in the BDCFs for this radionuclide as a function of the mass loading.

Figure 6.2-18. Dependence of BDCF for the Groundwater Exposure Scenario and the Present-Day Climate on the Atmospheric Mass Loading for the Inactive Outdoors Environment

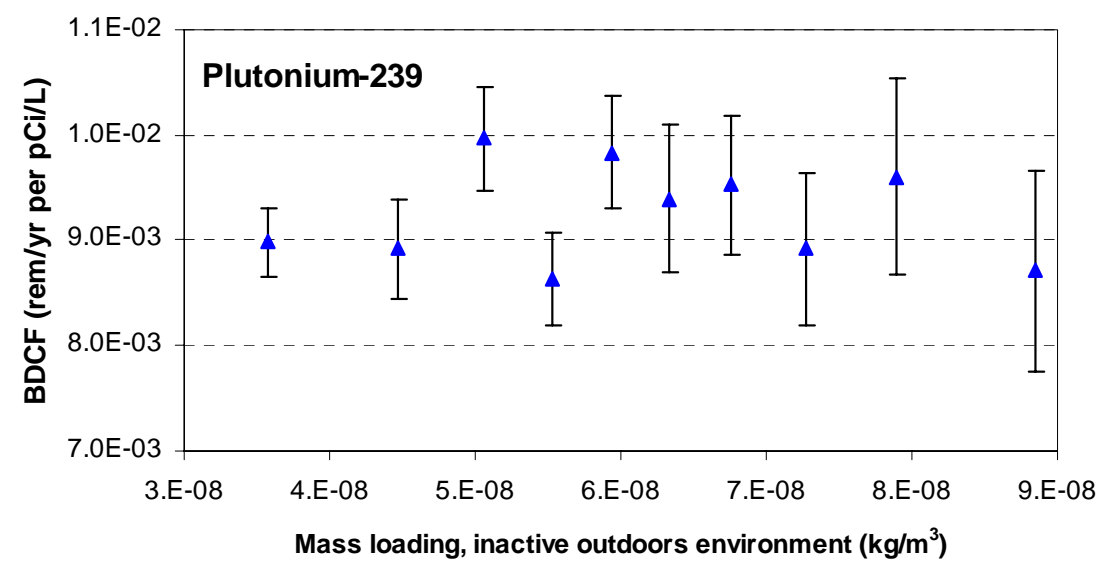


As shown in Figure 6.2-18, the BDCFs are insensitive to mass loading in the inactive outdoors environment. For example, based on a deterministic run of the model, tripling the mass loading value for this environment from $0.06 \mathrm{mg} / \mathrm{m}^{3}$ to $0.18 \mathrm{mg} / \mathrm{m}^{3}$ resulted in a change in the BDCF for ${ }^{239} \mathrm{Pu}$ from $7.68 \times 10^{-3} \mathrm{rem} / \mathrm{yr}$ per $\mathrm{pCi} / \mathrm{L}$ to $7.71 \times 10^{-3} \mathrm{rem} / \mathrm{yr}$ per $\mathrm{pCi} / \mathrm{L}$, that is, by 0.5 percent. BDCFs were calculated in a deterministic run of ERMYN_GW_MC8_Det_Base.gsm by changing the radionuclide selection and the value of mass loading. The percent change for the BDCFs was calculated in the Excel spreadsheet Dependence of $G W B D C F$ s on Inputs.xls (Appendix A).

\subsubsection{Radionuclide Transport to Crops}

Environmental transport pathways considered in the biosphere model for the groundwater exposure scenario that result in radionuclide transport to crops are:

- Deposition of contaminated water on crop surfaces

- Deposition of resuspended contaminated soil in crop surfaces

- Root uptakes of radionuclides present in surface soil

The relative contributions of these pathways to the overall activity concentration in a crop type is pathway and crop-type dependent. Table 6.2-10 summarizes the fractions of radionuclide concentration in the crop types considered in the biosphere model by transport process for a few selected radionuclides. The fractions for the present-day climate were calculated in the Excel file Detailed Pathway Analysis GW_MC.xls (Appendix A).

Table 6.2-10. Fractions of Activity in Crop Types from Considered Environmental Transport Pathways for Groundwater Exposure Scenario for Present-Day Climate

\begin{tabular}{|c|c|c|c|c|c|c|c|}
\hline \multirow[b]{2}{*}{ Radionuclide } & \multirow[b]{2}{*}{ Transport Process } & \multicolumn{5}{|c|}{ Crop Type } & \multirow[b]{2}{*}{ Average } \\
\hline & & $\begin{array}{c}\text { Leafy } \\
\text { Vegetables }\end{array}$ & $\begin{array}{c}\text { Other } \\
\text { Vegetables }\end{array}$ & Fruits & Grains & Forage & \\
\hline \multirow{3}{*}{ Tc-99 } & Irrigation water deposition & 0.307 & 0.363 & 0.373 & 0.492 & 0.349 & 0.377 \\
\hline & Dust deposition & 0.000 & 0.001 & 0.001 & 0.001 & 0.000 & 0.001 \\
\hline & Root uptake & 0.693 & 0.636 & 0.626 & 0.507 & 0.651 & 0.623 \\
\hline \multirow{3}{*}{$\mathrm{I}-129$} & Irrigation water deposition & 0.914 & 0.759 & 0.665 & 0.720 & 0.867 & 0.785 \\
\hline & Dust deposition & 0.027 & 0.018 & 0.020 & 0.024 & 0.026 & 0.023 \\
\hline & Root uptake & 0.060 & 0.222 & 0.314 & 0.256 & 0.107 & 0.192 \\
\hline \multirow{3}{*}{$U-233$} & Irrigation water deposition & 0.865 & 0.770 & 0.738 & 0.862 & 0.821 & 0.811 \\
\hline & Dust deposition & 0.069 & 0.056 & 0.070 & 0.076 & 0.067 & 0.068 \\
\hline & Root uptake & 0.066 & 0.175 & 0.192 & 0.062 & 0.112 & 0.121 \\
\hline \multirow{3}{*}{$\mathrm{Np}-237$} & Irrigation water deposition & 0.737 & 0.536 & 0.506 & 0.755 & 0.693 & 0.646 \\
\hline & Dust deposition & 0.044 & 0.032 & 0.042 & 0.051 & 0.042 & 0.042 \\
\hline & Root uptake & 0.218 & 0.432 & 0.452 & 0.194 & 0.265 & 0.312 \\
\hline \multirow{3}{*}{ Pu-239 } & Irrigation water deposition & 0.846 & 0.829 & 0.782 & 0.836 & 0.767 & 0.812 \\
\hline & Dust deposition & 0.146 & 0.133 & 0.166 & 0.155 & 0.133 & 0.147 \\
\hline & Root uptake & 0.008 & 0.038 & 0.052 & 0.010 & 0.099 & 0.041 \\
\hline
\end{tabular}

Source: Excel file Detailed Pathway Analysis GW_MC.xIs (Appendix A). 
Because there is a trend regarding the importance of environmental transport pathways for each radionuclide, regardless of crop type, the fractions of radionuclide concentrations for a radionuclide were averaged over all crop types included in the analysis. The results are shown in Table 6.2-10 and Figure 6.2-19 (see Excel file Detailed Pathway Analysis GW_MC.xls in Appendix A). This averaging was justified because the differences among the crop types were usually less than the differences between the mechanisms of radionuclide transport to a crop.

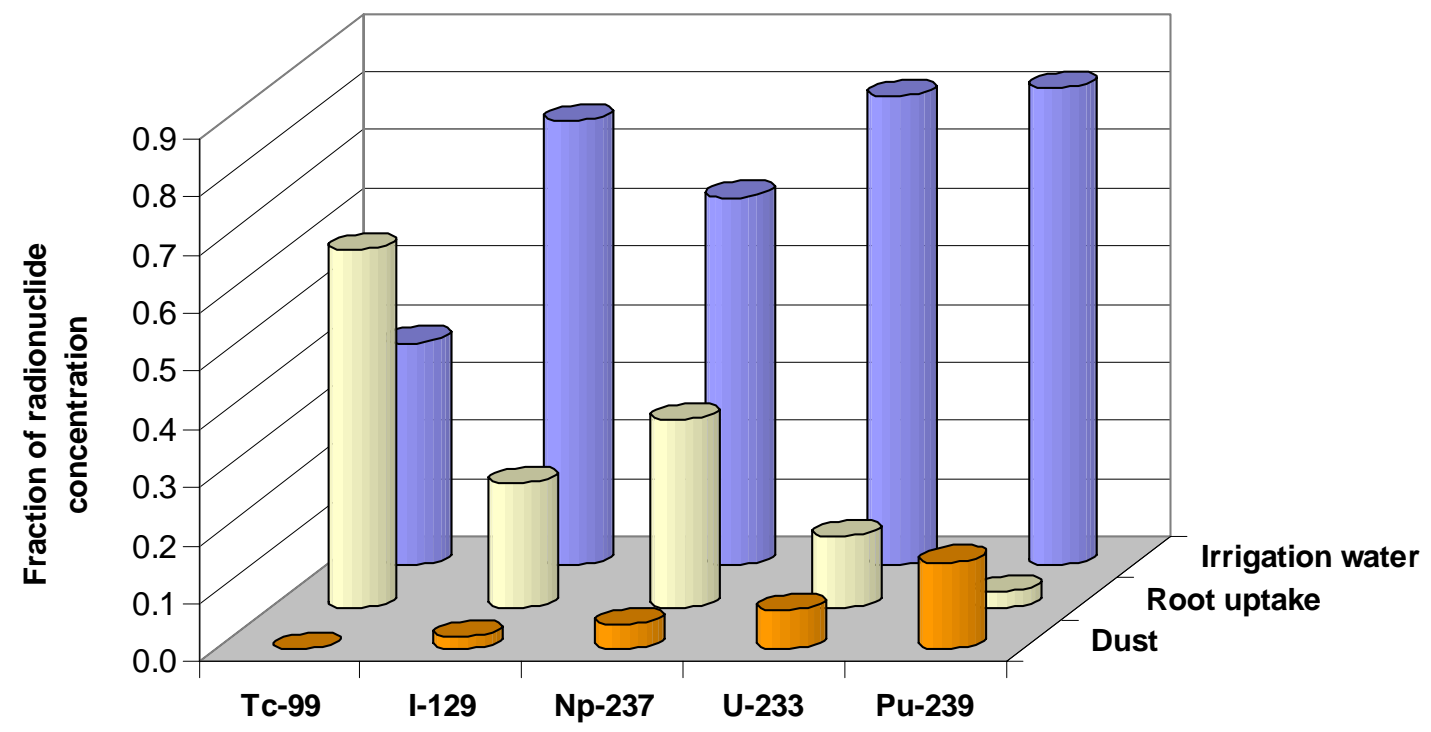

Source: Excel file Detailed Pathway Analysis GW_MC.xls (Appendix A).

Figure 6.2-19. Environmental Transport Pathway Contributions for Groundwater Exposure Scenario and Present-Day Climate Averaged for All Crop Types

Figure 6.2-19 shows that radionuclide deposition on plant surfaces from irrigation water is the dominant mechanism of activity transport to crops for all radionuclides except ${ }^{99} \mathrm{Tc}$. Root uptake is dominant for ${ }^{99} \mathrm{Tc}$ and a significant contributor for ${ }^{129} \mathrm{I}$ and ${ }^{237} \mathrm{~Np}$. Root uptake decreases as the atomic number increases and is relatively insignificant for ${ }^{239} \mathrm{Pu}$ because of its low uptake from the liquid phase, which is due to the high sorption properties of this element (it is preferably present in the solid phase). Particulate deposition is relatively unimportant, regardless of radionuclide, although it is greater for transuranics, which tend to accumulate in the soil to a greater degree than poorly sorbing elements such as technetium.

Not shown in Figure 6.2-19 is the relative importance of the environmental transport pathways leading to accumulation of ${ }^{14} \mathrm{C}$ in the plants. This is because the environmental transport of ${ }^{14} \mathrm{C}$ in the environment is evaluated in the biosphere model using a special submodel (BSC 2004 [DIRS 169460], Section 6.4.6), which is different than the plant submodel used for the other radionuclides (BSC 2004 [DIRS 169460], Section 6.4.3). This special submodel includes different mechanisms of carbon migration though the environment. Concentration of ${ }^{14} \mathrm{C}$ in crops and animal products is calculated based on the ratios of ${ }^{14} \mathrm{C}$ to stable carbon in the media that are the source of carbon for plants (air and soil) and for animals (feed, water, and soil), on the fraction of total carbon in plants or animal products that originates from these media, and on 
the carbon content of these media. The concentration of ${ }^{14} \mathrm{C}$ in crops and animal products thus reflects the relative abundance of ${ }^{14} \mathrm{C}$ and stable carbon in the environment. Pathway contributions for crops and animal products correspond to the consumption of these foodstuffs. In the case of ${ }^{14} \mathrm{C}$ transport to plants, almost 100 percent of ${ }^{14} \mathrm{C}$ in crops is from the air (carbon absorption during photosynthesis). The fraction of ${ }^{14} \mathrm{C}$ concentration in crops from root uptake is negligible (Excel file Detailed Pathway Analysis GW_MC.xls in Appendix A).

Similar calculations were performed for the future climate. The fractions of radionuclide concentration in various crop types for five selected radionuclides are presented in Table 6.2-11 (see Excel file Detailed Pathway Analysis GW_FC.xls in Appendix A). The differences between the proportions for the present-day climate and the future climate are a few percent or less. Thus, the conclusions for the present-day climate also apply to the future climate.

Table 6.2-11. Fractions of Activity in Crop Types from Considered Environmental Transport Processes for Groundwater Exposure Scenario for Future Climate

\begin{tabular}{|c|c|c|c|c|c|c|c|}
\hline \multirow[b]{2}{*}{ Radionuclide } & \multirow[b]{2}{*}{ Transport Process } & \multicolumn{5}{|c|}{ Crop Type } & \multirow[b]{2}{*}{ Average } \\
\hline & & $\begin{array}{c}\text { Leafy } \\
\text { Vegetables }\end{array}$ & \begin{tabular}{|c|} 
Other \\
Vegetables
\end{tabular} & Fruits & Grains & Forage & \\
\hline \multirow{3}{*}{ Tc-99 } & Irrigation water deposition & 0.320 & 0.323 & 0.334 & 0.523 & 0.348 & 0.370 \\
\hline & Dust deposition & 0.000 & 0.001 & 0.001 & 0.001 & 0.000 & 0.001 \\
\hline & Root uptake & 0.680 & 0.676 & 0.665 & 0.476 & 0.651 & 0.630 \\
\hline \multirow{3}{*}{$\mathrm{I}-129$} & Irrigation water deposition & 0.918 & 0.726 & 0.629 & 0.746 & 0.866 & 0.777 \\
\hline & Dust deposition & 0.024 & 0.021 & 0.022 & 0.021 & 0.025 & 0.023 \\
\hline & Root uptake & 0.057 & 0.253 & 0.349 & 0.233 & 0.109 & 0.200 \\
\hline \multirow{3}{*}{$\mathrm{Np}-237$} & Irrigation water deposition & 0.881 & 0.749 & 0.717 & 0.887 & 0.830 & 0.813 \\
\hline & Dust deposition & 0.061 & 0.060 & 0.074 & 0.062 & 0.063 & 0.064 \\
\hline & Root uptake & 0.058 & 0.191 & 0.209 & 0.050 & 0.108 & 0.123 \\
\hline \multirow{3}{*}{ Pu-239 } & Irrigation water deposition & 0.756 & 0.500 & 0.473 & 0.785 & 0.700 & 0.643 \\
\hline & Dust deposition & 0.040 & 0.035 & 0.045 & 0.044 & 0.041 & 0.041 \\
\hline & Root uptake & 0.203 & 0.465 & 0.482 & 0.171 & 0.260 & 0.316 \\
\hline \multirow{3}{*}{ Am-241 } & Irrigation water deposition & 0.868 & 0.819 & 0.775 & 0.868 & 0.787 & 0.823 \\
\hline & Dust deposition & 0.125 & 0.140 & 0.170 & 0.125 & 0.122 & 0.136 \\
\hline & Root uptake & 0.007 & 0.041 & 0.055 & 0.007 & 0.091 & 0.040 \\
\hline
\end{tabular}

Source: Excel file Detailed Pathway Analysis GW_FC.xIs (Appendix A).

Irrigation with contaminated water is an important environmental transport pathway for all radionuclides. Radionuclide concentrations in crops due to leaf uptake from contaminated irrigation water sprayed on plants is expressed as (adapted from BSC 2004 [DIRS 169460], Equation 6.4.3-3)

$$
C p_{\text {water }, j}=\frac{D w_{j} f_{o, j} R w_{j} T_{j}}{\lambda_{w} Y_{j}}\left(1-e^{-\lambda_{w} t_{g, j}}\right)
$$

where

$$
C p_{\text {water }, j}=\text { radionuclide concentration in crop type } j \text { due to application of irrigation }
$$




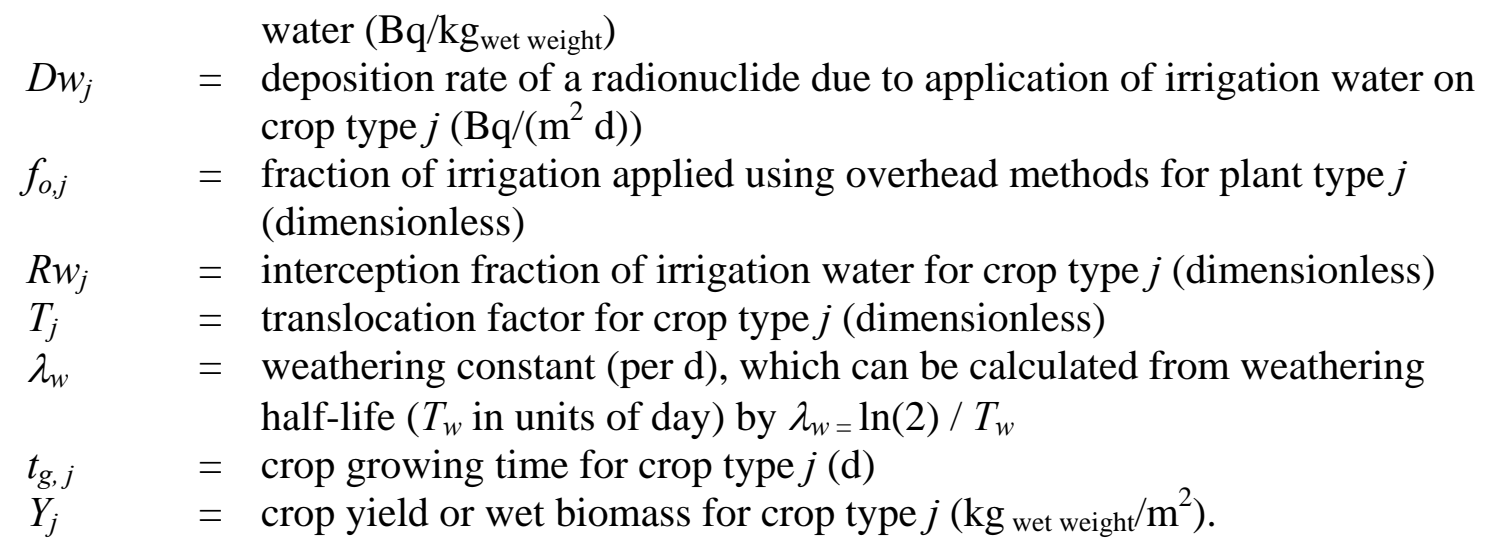

For overhead irrigation (i.e., sprinkler or spray), the rate of radionuclide deposition onto crops, $D w_{j}$, is the product of irrigation rate and radionuclide concentration in water. In this submodel, the radionuclide deposition rate from irrigation water is estimated as (adapted form BSC 2004 [DIRS 169460], Equation 6.4.3-4)

$$
D w_{j}=C w I R D_{j}
$$

where

$I R D_{j} \quad=$ daily average irrigation rate for crop type $j$ during the growing season $(\mathrm{m} / \mathrm{d})$

The result calculated using Equation 6.2-6 is relatively insensitive to the value of the term in the parentheses, containing an exponential function. This is because the weathering time is much shorter than the crop growing time (the weathering rate constant is relatively large), so the exponential term approaches values that are close to zero. The weathering half-life influences the BDCF values, especially for those radionuclides that have a significant fraction of their BDCF due to ingestion of locally produced food, as can be seen in Table 6.2-3.

For the remaining parameters, the radionuclide concentration in crops is directly proportional to the deposition rate, fraction of irrigation applied using overhead methods, interception fraction, and translocation, and inversely proportional to the weathering constant and crop yield. These parameters influence the radionuclide concentration in crops from irrigation, making this environmental transport pathway the most important transport mechanisms for contamination of crops, but they do not contribute to an appreciable degree to the uncertainty in the all-pathway BDCF (Table 6.2-3). One reason is that many agricultural parameters that are used for this pathway were developed based on representative crops and with consideration of site-specific conditions and, as the result, the level of uncertainty associated with these parameters is relatively low.

A parameter that received some attention in the past was the interception fraction for irrigation water. This parameter quantifies the amount of contaminated water intercepted by crop surfaces. The histograms of water interception fraction for all crop types used in the biosphere model are shown in Figure 6.2-20. The biosphere model is relatively insensitive to the value of this parameter, as illustrated in Figure $6.2-21$ for ${ }^{99} \mathrm{Tc}$, a radionuclide that has a high BDCF contribution from the ingestion of locally produced food. The water interception pathway is 
more important as a transport pathway for elements that are poorly taken up from the soil through their roots, as indicated in Figure 6.2-19. However, for these elements, ingestion of locally produced food is, overall, not a very important pathway, so the influence of the water interception fraction on the BDCFs for these radionuclides is expected to be even less.
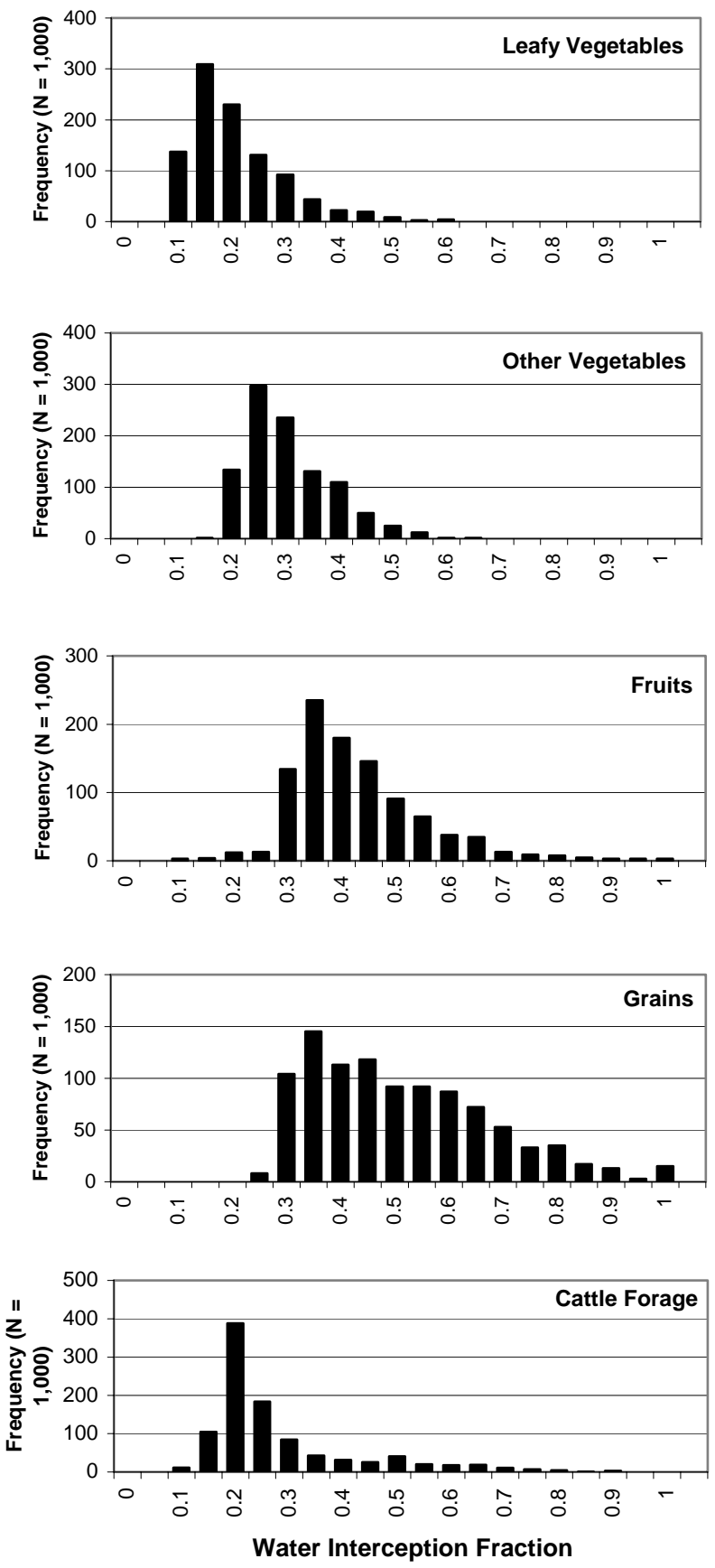

Source: Excel file Water Interception Fraction.xls (Appendix A).

Figure 6.2-20. Water Interception Fraction Histograms by Crop Type Resulting from 1,000 Realizations of the Biosphere Model 

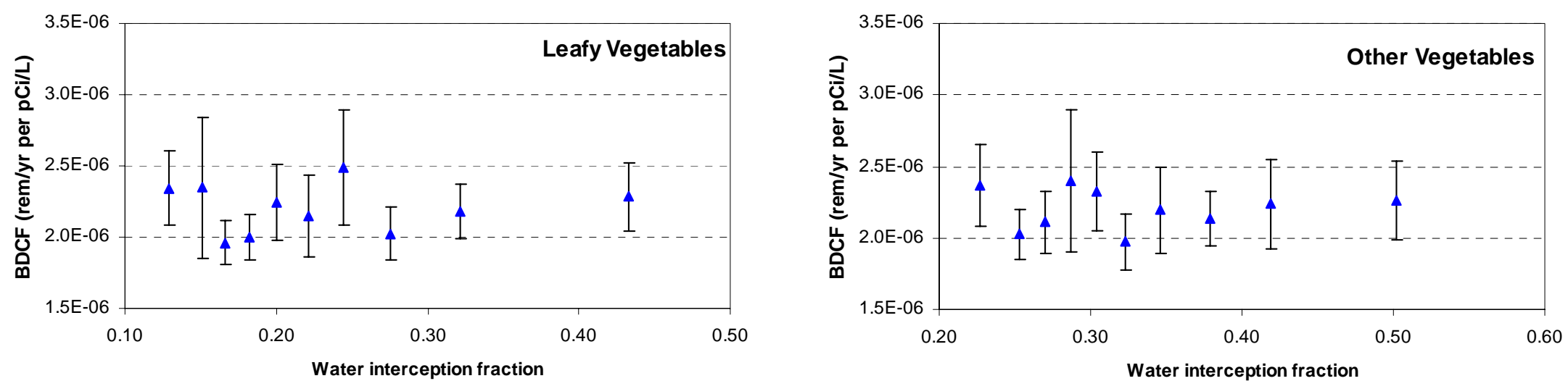

Source: Excel file Dependence of GW BDCFs on Inputs.xls (Appendix A).

NOTE: The triangles represent the mean of 100 values. The error bars represent the uncertainty range for the mean at the 95 percent uncertainty interval, calculated as 1.96 times the standard error of the mean. The outlier point with a high BDCF value for ${ }^{99} \mathrm{TC}$ was removed to better show the trend in the BDCFs for this radionuclide as a function of water interception fraction.

Figure 6.2-21. Dependence of ${ }^{99} \mathrm{Tc}$ BDCF for the Groundwater Exposure Scenario and Present-Day Climate on Water Interception Fraction by Type of Crops for Human Consumption 
The influence of irrigation interception fraction on BDCFs for five radionuclides was estimated in a series of deterministic model runs. The calculations were done for average and doubled irrigation interception fractions for all crops. The irrigation interception values used in the calculations are listed in Table 6.2-12 and the results are presented in Table 6.2-13.

Table 6.2-12 Irrigation Interception Fractions Used in Calculations

\begin{tabular}{|l|c|c|c|c|c|}
\hline $\begin{array}{c}\text { Irrigation Interception } \\
\text { Fraction }\end{array}$ & $\begin{array}{c}\text { Leafy } \\
\text { Vegetables }\end{array}$ & $\begin{array}{c}\text { Other } \\
\text { Vegetables }\end{array}$ & Fruit & Grain & Forage \\
\hline Average for all crops & 0.216 & 0.301 & 0.360 & 0.470 & 0.258 \\
\hline $2 \times$ Average for all crops & 0.432 & 0.602 & 0.719 & 0.940 & 0.516 \\
\hline
\end{tabular}

Table 6.2-13. BDCFs and Percent Change for Different Irrigation Interception Fractions

\begin{tabular}{|l|l|c|c|}
\hline \multirow{2}{*}{ Radionuclide } & \multicolumn{1}{|c|}{ Irrigation interception fraction } & \multicolumn{1}{c|}{$\begin{array}{c}\text { BDCF } \\
\text { rem/yr per pCi/L }\end{array}$} & $\begin{array}{c}\text { Percent Change } \\
\text { Relative to Average }\end{array}$ \\
\hline \multirow{4}{*}{ Technetium-99 } & Average for all crops & $1.380 \mathrm{E}-06$ & \\
\cline { 2 - 4 } & $2 \times$ Average for all crops & $1.483 \mathrm{E}-06$ & 7.5 \\
\hline \multirow{3}{*}{ lodine-129 } & Average for all crops & $2.588 \mathrm{E}-04$ & \\
\cline { 2 - 4 } & $2 \times$ Average for all crops & $2.913 \mathrm{E}-04$ & 12.5 \\
\hline \multirow{3}{*}{ Uranium-233 } & Average for all crops & $9.529 \mathrm{E}-04$ & \\
\cline { 2 - 4 } & $2 \times$ Average for all crops & $9.663 \mathrm{E}-04$ & 1.4 \\
\hline \multirow{3}{*}{ Neptunium-237 } & Average for all crops & $5.350 \mathrm{E}-03$ & \\
\cline { 2 - 4 } & $2 \times$ Average for all crops & $5.521 \mathrm{E}-03$ & 3.2 \\
\cline { 2 - 4 } & Average for all crops & $7.677 \mathrm{E}-03$ & \\
\hline
\end{tabular}

NOTE: BDCFs were calculated in deterministic runs of ERMYN_GW_MC8_Det_Base.gsm by changing the radionuclide selection and the value of mass loading. The percent change for the BDCFs was calculated in the Excel spreadsheet Dependence of GW BDCFs on Inputs.xls (Appendix A).

Doubling the irrigation interception fraction results, on average, in an increase in the BDCF of from about two percent for ${ }^{239} \mathrm{Pu}$ to about 13 percent for ${ }^{129} \mathrm{I}$.

Root uptake is the second most important environmental transport pathway that gives rise to radionuclide concentration in crops (Figure 6.2-19 and Table 6.2-11). The activity concentration of radionuclides in crops from root uptake is estimated as (adapted from BSC 2004 [DIRS 169460], Equation 6.4.3-2)

$$
C p_{\text {root }, j}=C s_{m} F_{s \rightarrow p, j} D W_{j}
$$

where

$$
\begin{aligned}
& C s_{m}=\text { activity concentration of the radionuclide in surface soil }(\mathrm{Bq} / \mathrm{kg} \text { dry soil }) \\
& F_{s \rightarrow p, j}=\text { soil-to-plant transfer factor for the radionuclide and crop type } j(\mathrm{~Bq} / \mathrm{kg} \text { dry plant } \\
& \text { per } \mathrm{Bq} / \mathrm{kg} \text { dry soil) } \\
& D W_{j} \quad=\quad \text { dry-to-wet weight ratio for edible part of plant }\left(\mathrm{kg} \text { dry-plant } / \mathrm{kg}_{\text {wet-plant }}\right) \text {. }
\end{aligned}
$$


The dry-to-wet weight ratio was developed from measurements of reference crops and has a low degree of uncertainty. The soil-to-plant transfer factor, in contrast, was developed based on literature data for many elements and crop types and has a relatively wide distribution. This uncertainty is transferred to the biosphere model results, as indicated by the results of the correlation analysis, which indicated that the soil-to-plant transfer factors are statistically significant contributors to the overall BDCF variance (see Table 6.2-3).

Of the radionuclides shown in Figure 6.2-19 and in Table 6.2-11, ${ }^{99} \mathrm{Tc}$ and ${ }^{237} \mathrm{~Np}$ have the highest fraction of activity in crops that is attributable to the root uptake. The dependence of the BDCFs for these two radionuclides on the transfer factors for the crop types considered in the biosphere model is presented in Figures 6.2-22 and 6.2-23, respectively.

The dependence of the BDCF for ${ }^{99} \mathrm{Tc}$ and ${ }^{237} \mathrm{~Np}$ on the soil-to-plant transfer factor corresponds to the BDCF dependence on the partition coefficients for these radionuclides (Figure 6.2-11) because these two parameters are correlated in the model. The correlation is negative because a high $K_{d}$ reduces the amount of an element present in solution and thus its availability for root uptake. This results in low transfer factors for high values of $K_{d} s$. Thus, the trends shown in Figures 6.2-22 and 6.2-23 for transfer factors reflect the opposite of trends shown in Figure 6.2-11 for the $\mathrm{K}_{\mathrm{d}} \mathrm{s}$. 

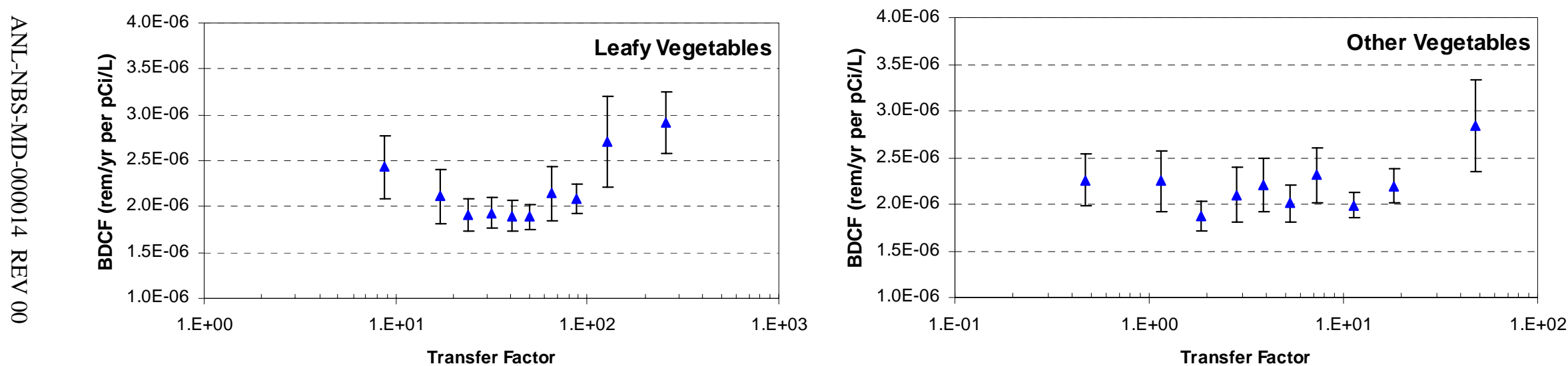

Source: Excel file Dependence of GW BDCFs on Inputs.xIs (Appendix A).

NOTE: The triangles represent the mean of 100 values. The error bars represent the uncertainty range for the mean at the 95 percent uncertainty interval, calculated as 1.96 times the standard error of the mean. The outlier point with a high BDCF value for ${ }^{99} \mathrm{Tc}$ was removed to better show the trend in the BDCFs for this radionuclide as a function of transfer factor.

Figure 6.2-22. Dependence of BDCFs for ${ }^{99} \mathrm{Tc}$ for the Groundwater Exposure Scenario and the Present-Day Climate on Transfer Factors by Crop Type 

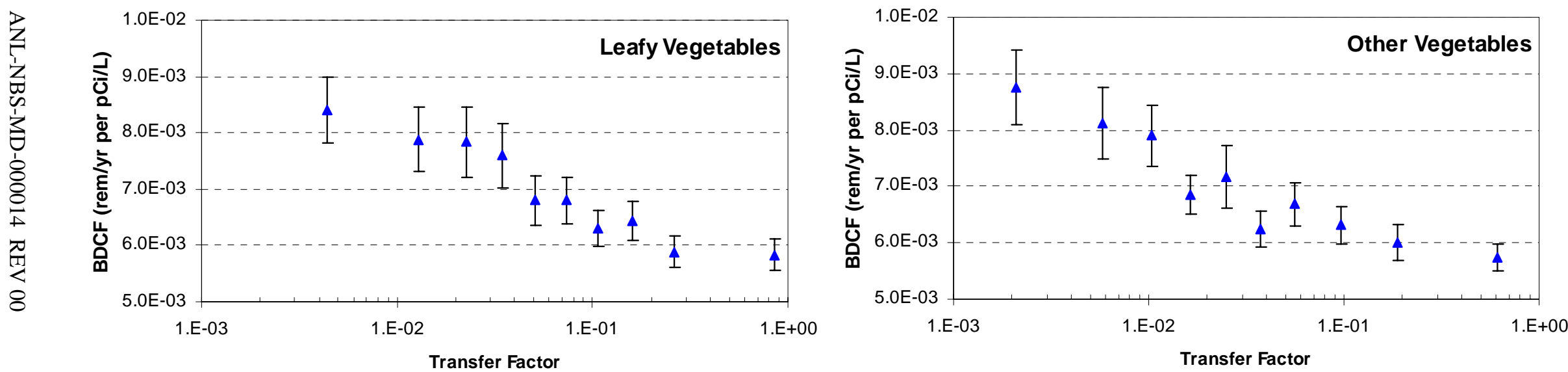

Source: Excel file Dependence of GW BDCFs on Inputs.xIs (Appendix A).

NOTE: The triangles represent the mean of 100 values. The error bars represent the uncertainty range for the mean at the 95 percent uncertainty interval, calculated as 1.96 times the standard error of the mean. The outlier point with a high BDCF value for ${ }^{99} \mathrm{Tc}$ was removed to better show the trend in the BDCFs for this radionuclide as a function of transfer factor.

Figure 6.2-23. Dependence of BDCFs for ${ }^{237} \mathrm{~Np}$ for the Groundwater Exposure Scenario and the Present-Day Climate on Transfer Factors by Crop Type. 


\subsubsection{Radionuclide Transport to Animal Products}

Environmental transport pathways considered in the biosphere model that result in radionuclide transport to animal products are animal consumption of feed; water; and soil; and, indirectly, environmental transport pathways leading to radionuclide accumulation in forage plants and in the surface soil.

The relative contributions of these pathways to the overall activity concentration in an animal product is pathway and animal-product dependent. Table 6.2-14 summarizes the fractions of radionuclide concentration in the animal products considered in the biosphere model by transport process for selected radionuclides. The fractions for the present-day climate were calculated in the Excel file Detailed Pathway Analysis GW_MC.xls (Appendix A).

Table 6.2-14. Fractions of Activity in Animal Products from Environmental Transport Pathways for Groundwater Exposure Scenario for Present-Day Climate

\begin{tabular}{|c|c|c|c|c|c|c|c|}
\hline \multirow[b]{2}{*}{ Radionuclide } & \multirow[b]{2}{*}{ Transport Process } & \multicolumn{4}{|c|}{ Animal Product } & \multirow{2}{*}{$\begin{array}{c}\text { Average } \\
\text { Meat and } \\
\text { Milk }\end{array}$} & \multirow{2}{*}{$\begin{array}{c}\text { Average } \\
\text { Poultry and } \\
\text { Eggs }\end{array}$} \\
\hline & & Meat & Milk & Poultry & Eggs & & \\
\hline \multirow{3}{*}{ Tc-99 } & Feed Consumption & 0.968 & 0.968 & 0.851 & 0.850 & 0.968 & 0.851 \\
\hline & Water Consumption & 0.030 & 0.030 & 0.108 & 0.107 & 0.030 & 0.107 \\
\hline & Soil Consumption & 0.003 & 0.003 & 0.041 & 0.042 & 0.003 & 0.042 \\
\hline \multirow{3}{*}{$\mathrm{I}-129$} & Feed Consumption & 0.794 & 0.789 & 0.560 & 0.561 & 0.792 & 0.560 \\
\hline & Water Consumption & 0.078 & 0.078 & 0.102 & 0.102 & 0.078 & 0.102 \\
\hline & Soil Consumption & 0.128 & 0.132 & 0.338 & 0.338 & 0.130 & 0.338 \\
\hline \multirow{3}{*}{ U-233 } & Feed Consumption & 0.668 & 0.659 & 0.341 & 0.344 & 0.664 & 0.342 \\
\hline & Water Consumption & 0.061 & 0.061 & 0.081 & 0.080 & 0.061 & 0.081 \\
\hline & Soil Consumption & 0.271 & 0.280 & 0.577 & 0.577 & 0.276 & 0.577 \\
\hline \multirow{3}{*}{ Np-237 } & Feed Consumption & 0.743 & 0.734 & 0.359 & 0.360 & 0.739 & 0.359 \\
\hline & Water Consumption & 0.052 & 0.052 & 0.062 & 0.062 & 0.052 & 0.062 \\
\hline & Soil Consumption & 0.205 & 0.213 & 0.579 & 0.578 & 0.209 & 0.579 \\
\hline \multirow{3}{*}{ Pu-239 } & Feed Consumption & 0.448 & 0.433 & 0.109 & 0.110 & 0.440 & 0.109 \\
\hline & Water Consumption & 0.029 & 0.029 & 0.016 & 0.016 & 0.029 & 0.016 \\
\hline & Soil Consumption & 0.523 & 0.538 & 0.875 & 0.874 & 0.531 & 0.875 \\
\hline
\end{tabular}

Source: Excel file Detailed Pathway Analysis GW_MC.xIs (Appendix A).

To show trends regarding the importance of environmental transport processes for a given radionuclide, the fractions of radionuclide concentrations for a radionuclide were averaged over animal products of bovine origin (meat and milk) and poultry origin (poultry and eggs) included in the analysis. The results are shown in Table 6.2-14, and Figures 6.2-24 and 6.2-25, for meat and milk and for poultry and eggs, respectively. This averaging was justified because the differences between individual animal products (milk and meat as well as poultry and eggs) were usually much less than the differences between the mechanisms of radionuclide transport to these products. 


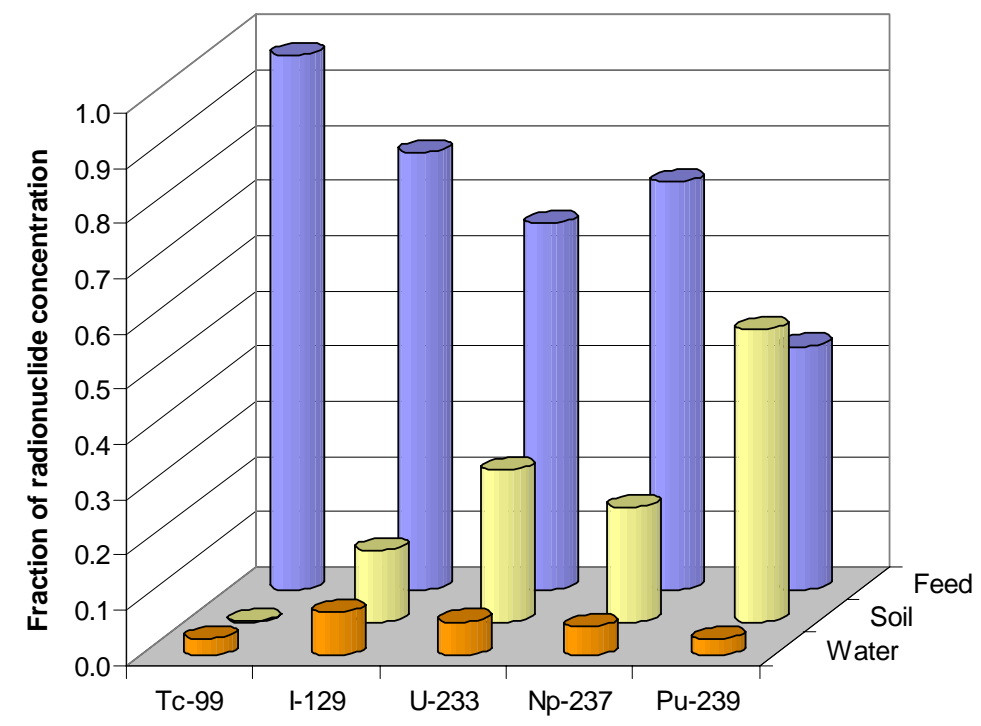

Source: Excel file Detailed Pathway Analysis GW_MC.xIs (Appendix A).

Figure 6.2-24. Average Contributions of Environmental Transport Pathways to Radionuclide Transport to Meat and Milk

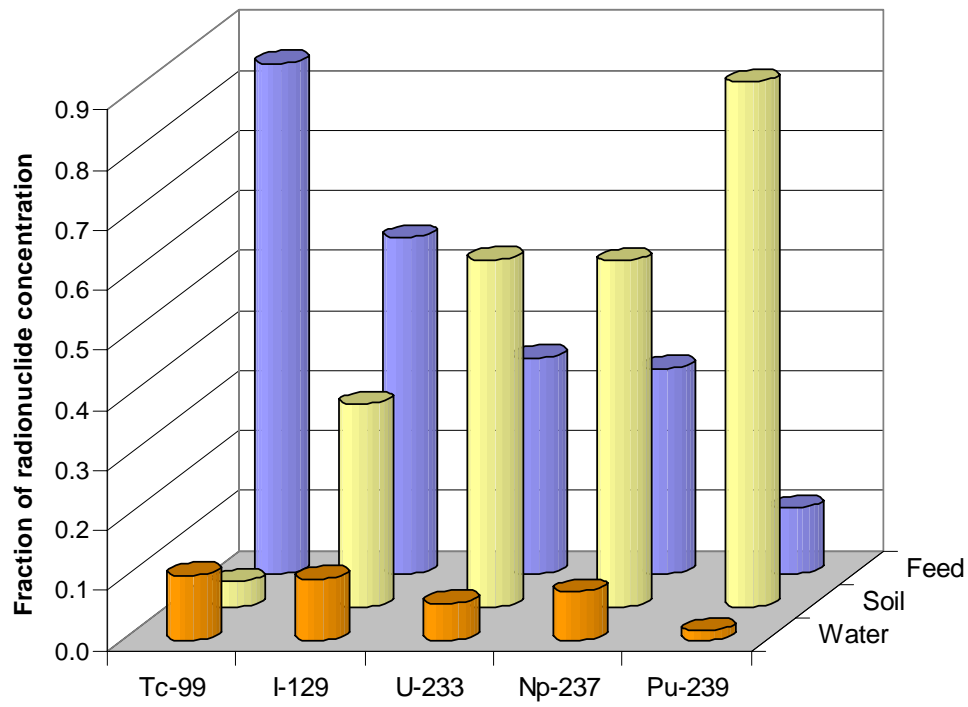

Source: Excel file Detailed Pathway Analysis GW_MC.xls (Appendix A).

Figure 6.2-25. Average Contributions of Environmental Transport Pathways to Radionuclide Transport to Poultry and Eggs

Figures 6.2-24 and 6.2-25 show that for meat and milk, the contribution from animal feed is dominant for all radionuclides except ${ }^{239} \mathrm{Pu}$; for poultry and eggs, animal feed contributes the most for ${ }^{99} \mathrm{Tc}$ and ${ }^{129} \mathrm{I}$. The contribution from ingestion of soil generally increases with atomic number and especially dominates for ${ }^{239} \mathrm{Pu}$. This is due to the buildup of these radionuclides in surface soil that is irrigated with contaminated water over a long period of time and to the 
relatively high soil intake by chickens. Ingestion of water is relatively unimportant regardless of the radionuclide and the animal product.

Not shown is the relative importance of the environmental transport pathways leading to accumulation of ${ }^{14} \mathrm{C}$ in animal products. This is because the environmental transport of ${ }^{14} \mathrm{C}$ in the environment is evaluated in the biosphere model using a special submodel (BSC 2004 [DIRS 169460], Section 6.4.6), which is different than the animal submodel used for the other radionuclides (BSC 2004 [DIRS 169460], Section 6.4.4). This special submodel includes different mechanisms of carbon migration though the environment. In the case of ${ }^{14} \mathrm{C}$ transport to animal products, the fraction of ${ }^{14} \mathrm{C}$ intake from feed is $97-98$ percent, 2-3 percent from water, and less than 0.02 percent from soil.

Similar calculations were performed for the future climate. The fractions of radionuclide concentration in animal products for five radionuclides are presented in Table 6.2-15. The differences between the proportions for the present-day climate and the future climate are a few percent or less. Thus, the conclusions for the present-day climate also apply to the future climate.

Table 6.2-15. Fractions of Activity in Animal Products from Environmental Transport Pathways for Groundwater Exposure Scenario for the Future Climate

\begin{tabular}{|c|c|c|c|c|c|c|c|}
\hline \multirow[b]{2}{*}{ Radionuclide } & \multirow[b]{2}{*}{ Transport Process } & \multicolumn{4}{|c|}{ Animal Product } & \multirow{2}{*}{$\begin{array}{c}\text { Average } \\
\text { Meat and } \\
\text { Milk }\end{array}$} & \multirow{2}{*}{$\begin{array}{c}\text { Average } \\
\text { Poultry and } \\
\text { Eggs }\end{array}$} \\
\hline & & Meat & Milk & Poultry & Eggs & & \\
\hline \multirow{3}{*}{ Tc-99 } & Feed Consumption & 0.953 & 0.953 & 0.824 & 0.824 & 0.953 & 0.824 \\
\hline & Water Consumption & 0.044 & 0.044 & 0.139 & 0.138 & 0.044 & 0.138 \\
\hline & Soil Consumption & 0.003 & 0.003 & 0.037 & 0.038 & 0.003 & 0.038 \\
\hline \multirow{3}{*}{$\mathrm{I}-129$} & Feed Consumption & 0.766 & 0.762 & 0.559 & 0.559 & 0.764 & 0.559 \\
\hline & Water Consumption & 0.112 & 0.113 & 0.132 & 0.132 & 0.113 & 0.132 \\
\hline & Soil Consumption & 0.121 & 0.125 & 0.309 & 0.309 & 0.123 & 0.309 \\
\hline \multirow{3}{*}{$\mathrm{U}-233$} & Feed Consumption & 0.657 & 0.648 & 0.355 & 0.357 & 0.652 & 0.356 \\
\hline & Water Consumption & 0.090 & 0.090 & 0.106 & 0.104 & 0.090 & 0.105 \\
\hline & Soil Consumption & 0.253 & 0.262 & 0.540 & 0.539 & 0.258 & 0.539 \\
\hline \multirow{3}{*}{ Np-237 } & Feed Consumption & 0.729 & 0.720 & 0.377 & 0.379 & 0.725 & 0.378 \\
\hline & Water Consumption & 0.078 & 0.078 & 0.086 & 0.086 & 0.078 & 0.086 \\
\hline & Soil Consumption & 0.193 & 0.202 & 0.537 & 0.536 & 0.197 & 0.536 \\
\hline \multirow{3}{*}{ Pu-239 } & Feed Consumption & 0.467 & 0.453 & 0.136 & 0.136 & 0.460 & 0.136 \\
\hline & Water Consumption & 0.049 & 0.048 & 0.027 & 0.027 & 0.049 & 0.027 \\
\hline & Soil Consumption & 0.484 & 0.499 & 0.837 & 0.837 & 0.491 & 0.837 \\
\hline
\end{tabular}

Source: Excel file Detailed Pathway Analysis GW_FC.xls (Appendix A).

${ }^{99}$ Tc and ${ }^{129}$ I are examples of radionuclides that have a higher proportion of BDCF that is due to consumption of locally produced animal products than most other radionuclides. For most radionuclides, especially actinides, ingestion of animal products is not an important exposure pathway (see Tables 6.2-1 and 6.2-2). 
For ${ }^{14} \mathrm{C}, 97$ to 98 percent of this radionuclide in animal products is from ingestion of feed, and 2 to 3 percent from ingestion of water. Ingestion of soil is a negligible source of ${ }^{14} \mathrm{C}$ in animal products.

The concentration of a radionuclide in a specific animal product $\left(C d_{k}\right)$ (BSC 2004 [DIRS 169460], Section 6.4.4) is calculated in the biosphere model as (adapted from BSC 2004 [DIRS 169460], Sections 6.4.4.1 through 6.4.4.4):

$$
C d_{k}=F m_{k}\left(C p_{j} Q f_{k}+C w Q w_{k}+C s_{m} Q s_{k}\right)
$$

where

$$
\begin{aligned}
& C d_{k}=\text { activity concentration of a radionuclide in animal product } k(\mathrm{~Bq} / \mathrm{kg} \text { fresh weight } \\
& \text { or } \mathrm{Bq} / \mathrm{L} \text { for milk) } \\
& k \quad=\text { animal product index; } k=1 \text { for beef, } 2 \text { for milk, } 3 \text { for poultry, } 4 \text { for eggs } \\
& \mathrm{Fm}_{k} \quad=\text { animal intake-to-animal product transfer coefficient for the radionuclide and } \\
& \text { animal product } k(\mathrm{~d} / \mathrm{kg} \text { fresh weight or } \mathrm{d} / \mathrm{L} \text { for milk) } \\
& C p_{j} \quad=\text { activity concentration of the radionuclide in animal feed } j(\mathrm{~Bq} / \mathrm{kg} \text { fresh weight }) \\
& Q f_{k} \quad=\text { animal consumption rate of feed }(\mathrm{kg} / \mathrm{d}) \\
& C w=\text { activity concentration of the radionuclide in groundwater }(\mathrm{Bq} / \mathrm{L}) \\
& Q w_{k} \quad=\text { animal consumption rate of water }(\mathrm{L} / \mathrm{d}) \\
& C s_{m} \quad=\text { equilibrium activity concentration of the radionuclide in surface soil per unit } \\
& \text { mass }(\mathrm{Bq} / \mathrm{kg}) \\
& Q s_{k} \quad=\text { animal consumption rate of soil }(\mathrm{kg} / \mathrm{d})
\end{aligned}
$$

The radionuclide concentration in animal products is the product of the animal intake of a radionuclide and the animal intake-to-animal product transfer coefficient. Animal intake, in turn is a product of a radionuclide concentration in the ingested medium (feed, water, and soil) and the animal consumption rate of this medium. The environmental transport pathways for the soil and animal feed are described in Sections 6.2.4.1 and 6.2.4.3, respectively. As noted previously, only the intake of feed and soil are significant contributors to radionuclide concentrations in animal products.

The dependence of BDCFs for ${ }^{99} \mathrm{Tc}$ on the value of the transfer coefficient for animal products is shown in Figure 6.2-26. This radionuclide was chosen because it has a relatively high BDCF contribution from the consumption of locally produced animal products. The BDCFs tend to increase as the transfer coefficients for meat, milk and eggs increase but only in the upper region of the range of transfer coefficients. The variability in the BDCF does not depend strongly on the variability in animal consumption rates appearing in Equation 6.2-9, as shown in Figure 6.2-27 for ${ }^{99} \mathrm{Tc}$ and also in Table 6.2-3. This is because these parameters tend to have relatively narrow distributions. 

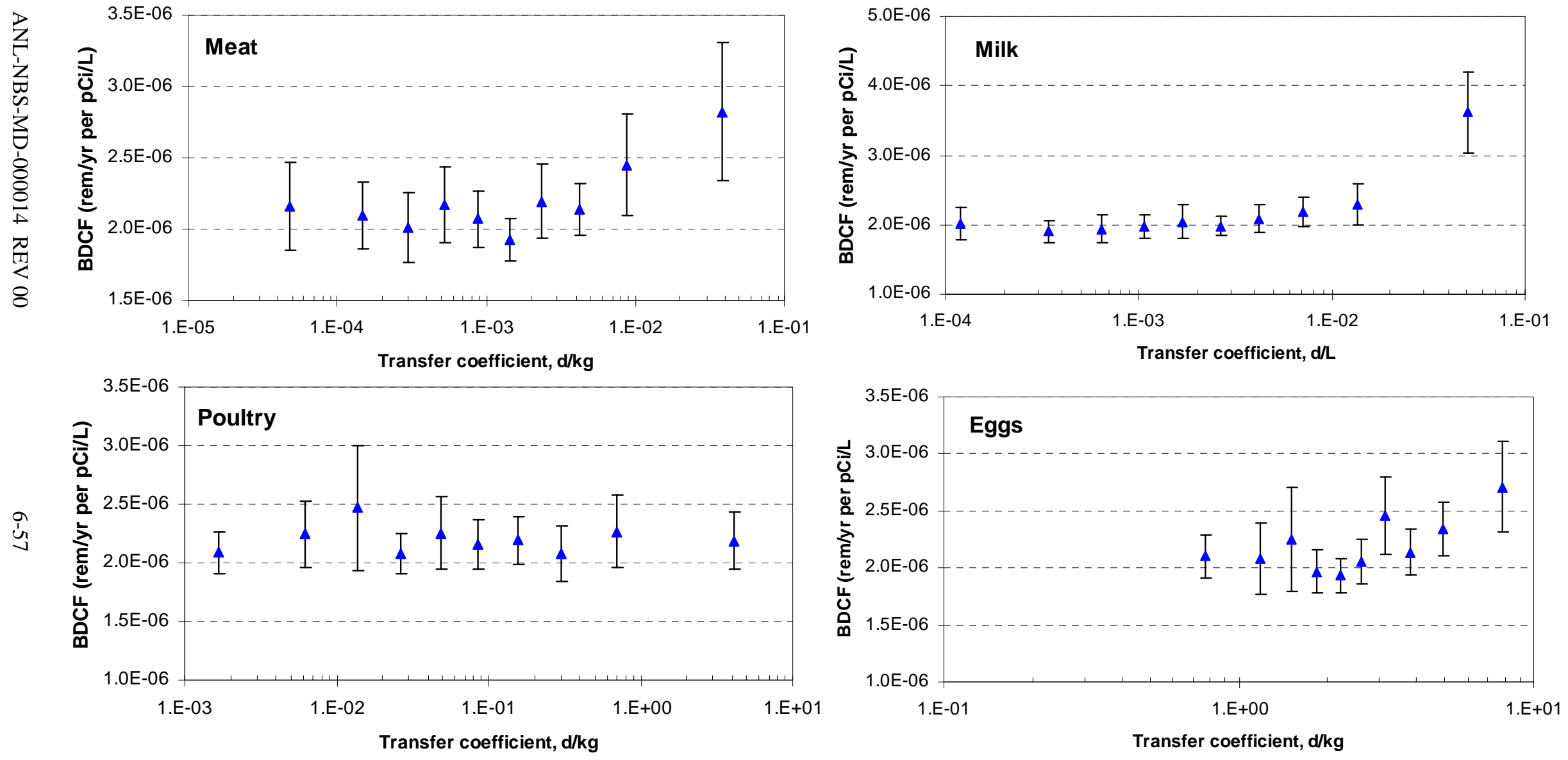

Source: Excel file Dependence of GW BDCFs on Inputs.xls (Appendix A).

NOTE: The triangles represent the mean of 100 values. The error bars represent the uncertainty range for the mean at the 95 percent uncertainty interval, calculated as 1.96 times the standard error of the mean. The outlier point with a high BDCF value for ${ }^{99} \mathrm{Tc}$ was removed to better show the trend in the BDCFs for this radionuclide as a function of transfer coefficient.

Figure 6.2-26. Dependence of BDCF for ${ }^{99} \mathrm{Tc}$ for the Groundwater Exposure Scenario and the Present-Day Climate on Transfer Coefficients by Animal Product 

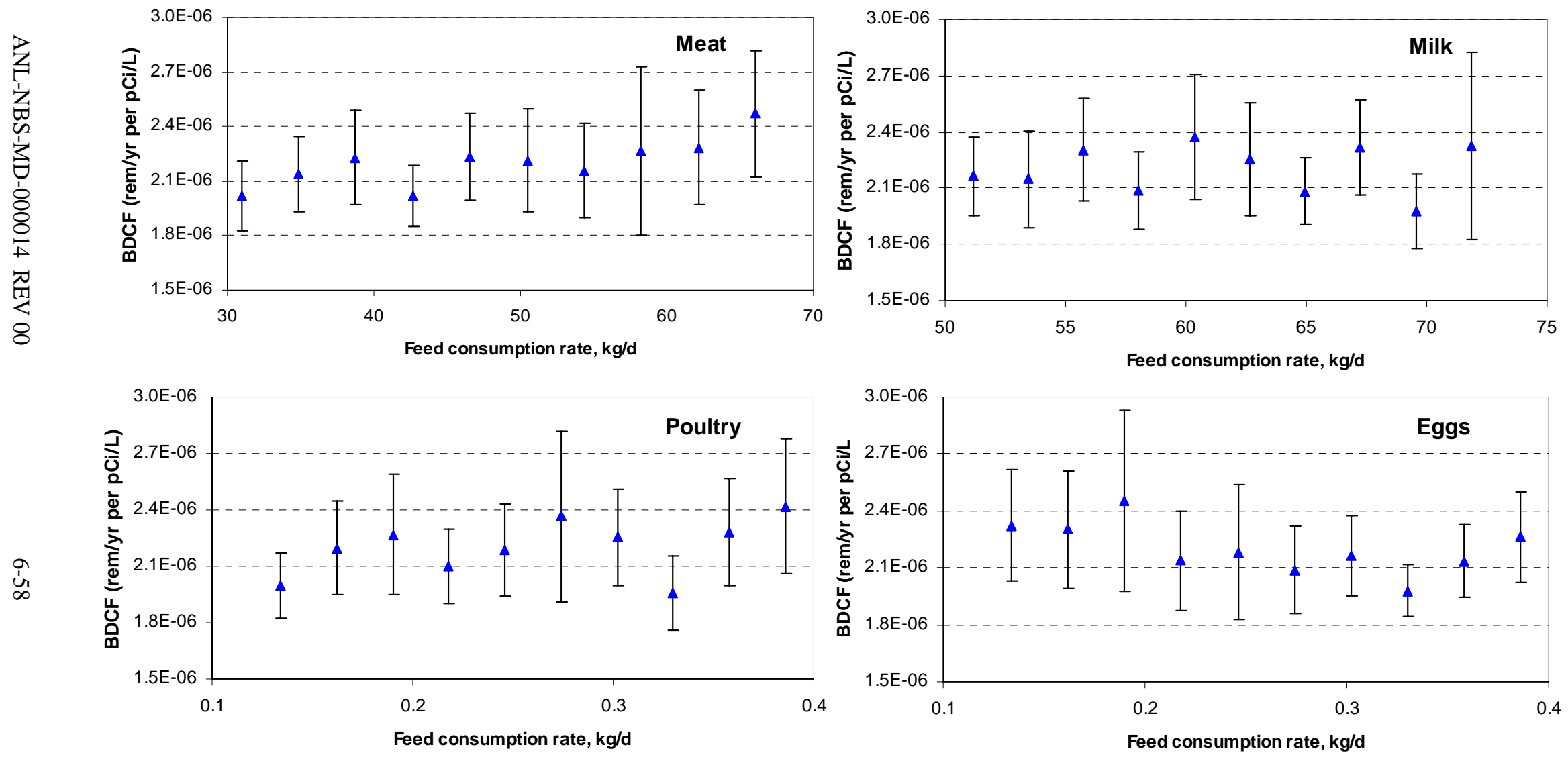

Source: Excel file Dependence of GW BDCFs on Inputs.xIs (Appendix A).

NOTE: The triangles represent the mean of 100 values. The error bars represent the uncertainty range for the mean at the 95 percent uncertainty interval, calculated as 1.96 times the standard error of the mean. The outlier point with a high BDCF value for ${ }^{99} \mathrm{Tc}$ was removed to better show the trend in the BDCFs for this radionuclide as a function of feed consumption rates.

Figure 6.2-27. Dependence of BDCF for ${ }^{99} \mathrm{Tc}$ for the Groundwater Exposure Scenario and the Present-Day Climate on Animal Feed Consumption Rates by Animal Product 


\subsubsection{Radionuclide Transport to Aquatic Food}

The activity concentration in fish is calculated as (adapted from BSC 2004 [DIRS 169460], Equation 6.4.5-2)

$$
C f=C w M F B F
$$

where

Cf $\quad=$ activity concentration of a radionuclide in fish $(\mathrm{Bq} / \mathrm{kg}$ wet $)$

$B F=$ bioaccumulation factor for the radionuclide in freshwater fish $(\mathrm{L} / \mathrm{kg})$

$\mathrm{Cw}=$ activity concentration of the radionuclide in groundwater $(\mathrm{Bq} / \mathrm{L})$

$M F \quad=\quad$ water concentration modifying factor for the radionuclide (dimensionless)

The water concentration modifying factor accounts for water evaporation from fish ponds and is developed using site-specific conditions. It has a small range of uncertainty relative to the distribution of the bioaccumulation factor, which was developed from a literature review. The bioaccumulation of radionuclides in fish is element specific and the fish consumption pathway is important for only a few radionuclides that have high values of bioaccumulation factor (carbon, cesium, and lead). The bioaccumulation of these elements in fish is overestimated, especially for carbon, because farmed fish in Amargosa Valley received uncontaminated commercially produced feed (BSC 2004 [DIRS 169672], Sections 6.4.2 and 6.4.3). Bioaccumulation factors reported in literature and used in the biosphere model were measured in natural systems and include the influence of contaminated food.

\subsubsection{Analysis of the Receptor Exposure Pathways}

The dose to the receptor is influenced by radionuclide levels in the environmental media (Section 6.2.4). It is also influenced by the factors that control the intake of these media for ingestion and inhalation and by the duration of exposure to radionuclides in media that are external to the receptor. These factors are discussed in this section.

\subsubsection{Ingestion}

The ingestion dose to the receptor arises from consumption of contaminated water and locally produced food. The dose from consumption of a given food type is calculated in the biosphere model as the product of radionuclide concentrations in the foodstuff, the consumption rate, and the dose coefficient converting radionuclide intake by ingestion to dose.

Ingestion of contaminated water is an important pathway for almost all radionuclides, as shown in Tables 6.2-1 and 6.2-2. This component of the annual dose to the receptor is defined by the rule at 10 CFR 63.312(d) [DIRS 156605], which requires that the RMEI's consumption of water is $2 \mathrm{~L} / \mathrm{d}$; it is not evaluated in this section.

The pathway contributions from consumption of locally produced food (Tables 6.2-1 and 6.2-2) are directly proportional to consumption rates of these foods. The consumption rates of locally produced food were developed based on the dietary characteristics of Amargosa Valley residents. Because food consumption rates are represented in the model by the distribution of 
their averages, as required in 10 CFR 63.312(b) [DIRS 156605], the variance in their values is relatively small.

To evaluate the sensitivity of BDCFs to consumption rates, deterministic model runs using the mean or best estimate input parameter values were performed for selected radionuclides at different levels of consumption rates. First, the "baseline” BDCF levels were established by using the mean values of the current consumption rates for the RMEI. Then, BDCFs for the same radionuclides were calculated using doubled consumption rates of locally produced food. Finally, the consumption rates for an average member of the critical group were used. The average member of the critical group was a receptor that was used to calculate BDCFs for the TSPA for the site recommendation (CRWMS M\&O 2001 [DIRS 152539]). Regarding the dietary characteristics, the critical group consisted of those Amargosa Valley residents that consumed locally produced food and had vegetable gardens (CRWMS M\&O 2001 [DIRS 153342], Section 7). The dietary characteristics of the RMEI reflect averages for the adult Amargosa Valley population. The consumption rates of locally produced food for these three receptors are presented in Table 6.2-16.

Table 6.2-16. Annual Consumption Rates of Locally Produced Food Used in the Evaluation

\begin{tabular}{|c|c|c|c|c|c|c|c|c|c|c|}
\hline \multirow[b]{2}{*}{ Receptor } & \multicolumn{10}{|c|}{ Consumption Rate by Food Type (kg/yr) } \\
\hline & $\begin{array}{l}\text { ऐ্ } \\
\text { సँ }\end{array}$ & 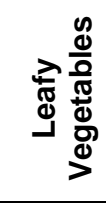 & 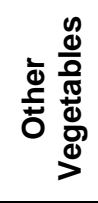 & $\begin{array}{l}\text { 売 } \\
\text { 市 }\end{array}$ & $\begin{array}{l}\frac{5}{\pi} \\
\frac{\pi}{0}\end{array}$ & $\begin{array}{l}\bar{\pi} \\
\stackrel{\pi}{\Sigma}\end{array}$ & 竞 & $\begin{array}{l}\stackrel{\lambda}{ \pm} \\
\frac{ \pm}{\partial} \\
a\end{array}$ & : & $\frac{5}{\frac{9}{4}}$ \\
\hline RMEl $^{a}$ & 730.5 & 3.78 & 4.73 & 12.68 & 0.23 & 2.85 & 4.66 & 0.42 & 5.3 & 0.23 \\
\hline $\begin{array}{l}2 \times \mathrm{RMEI} \\
\text { consumption }\end{array}$ & 730.5 & 7.56 & 9.46 & 25.36 & 0.46 & 5.7 & 9.32 & 0.84 & 10.6 & 0.46 \\
\hline Critical group $^{b}$ & $730.5^{c}$ & 15.14 & 7.81 & 15.57 & 0.48 & 2.93 & 4.14 & 0.8 & 6.68 & 0.47 \\
\hline
\end{tabular}

Sources: ${ }^{a}$ DTN: MO0407SPACRBSM.002.

b CRWMS M\&O 2001 [DIRS 153342], Table 11.

${ }^{c}$ The actual average consumption rate for an average member of the critical group was $752.85 \mathrm{~L} / \mathrm{yr}$, but this parameter was not changed in this analysis.

The BDCFs calculated using the consumption rates shown in Table 6.2-16 are summarized in Table 6.2-17. Table 6.2-17 also includes the percent change in the BDCF for a given consumption rate relative to the BDCF for the RMEI. 
Table 6.2-17. BDCFs for Different Levels of Consumption of Locally Produced Food

\begin{tabular}{|l|c|c|c|c|c|}
\hline & RMEI & \multicolumn{2}{|c|}{ Double RMEI Consumption } & \multicolumn{2}{c|}{ Critical Group } \\
\cline { 2 - 6 } Radionuclide & BDCF & BDCF & $\begin{array}{c}\text { Percent Change } \\
\text { Relative to the } \\
\text { RMEI }\end{array}$ & $\begin{array}{c}\text { Percent Change } \\
\text { Relative to the } \\
\text { RMEI }\end{array}$ \\
\hline Carbon-14 & $7.14 \mathrm{E}-06$ & $1.28 \mathrm{E}-05$ & 78.6 & $1.10 \mathrm{E}-05$ & 53.8 \\
\hline Technetium-99 & $1.38 \mathrm{E}-06$ & $1.68 \mathrm{E}-06$ & 21.7 & $1.73 \mathrm{E}-06$ & 25.1 \\
\hline lodine-129 & $2.59 \mathrm{E}-04$ & $3.15 \mathrm{E}-04$ & 21.7 & $2.93 \mathrm{E}-04$ & 13.2 \\
\hline Uranium-233 & $9.53 \mathrm{E}-04$ & $9.80 \mathrm{E}-04$ & 2.8 & $9.81 \mathrm{E}-04$ & 2.9 \\
\hline Neptunium-237 & $5.35 \mathrm{E}-03$ & $5.75 \mathrm{E}-03$ & 7.5 & $5.86 \mathrm{E}-03$ & 9.6 \\
\hline Plutonium-239 & $7.68 \mathrm{E}-03$ & $7.96 \mathrm{E}-03$ & 3.7 & $8.08 \mathrm{E}-03$ & \multicolumn{2}{|c|}{5.2} \\
\hline
\end{tabular}

NOTE: BDCFs were calculated in deterministic runs of ERMYN_GW_MC8_Det_Base.gsm by changing the radionuclide selection and the values of food consumption rates. The percent change for the BDCFs was calculated in the Excel spreadsheet Dependence of GW BDCFs on Inputs.xIs (Appendix A).

The values in Table 6.2-14 indicate that the BDCFs for actinides are relatively unaffected by changes in the consumption rates of locally produced food. The BDCFs for these radionuclides increase no more than about 10 percent. The BDCF for ${ }^{99} \mathrm{Tc}$ increases by about 22 percent when food consumption is doubled. The greatest difference is for ${ }^{14} \mathrm{C}$ because of the large proportion of the BDCF arising from consumption of food, especially fish. However, as noted in Section 6.2.4.5, the dose from the fish consumption is overestimated for carbon because of the use of uncontaminated feed in the fishery (fish get their carbon primarily from their food, not from the water).

The other part of the analysis of the ingestion pathway was an evaluation of the effects of the receptor change from an average member of the critical group to the RMEI, in terms of their consumption rates. Because the critical group consisted of those Amargosa Valley residents that had a vegetable garden, their consumption rate of locally grown food, especially crops, was higher than average (i.e., higher than that of the RMEI). The differences between the consumption rates of the RMEI and an average member of the critical group also result from recategorizing tomatoes from the leafy vegetable crop type to the fruit crop type.

The BDCFs for the critical group consumption rate were 54 percent higher for ${ }^{14} \mathrm{C}$ and 25 percent higher or less for the other radionuclides. The difference was smallest for actinides because food consumption is not an important pathway for these radionuclides (Table 6.2-1).

\subsubsection{Inhalation}

The following components of the inhalation pathway are included in the biosphere model:

- Inhalation of particulate matter

- Inhalation of aerosols generated by an evaporative cooler

- Inhalation of radon decay products

- Inhalation of ${ }^{14} \mathrm{CO}_{2}$.

Inhalation of radon decay products is the most important pathway for ${ }^{226} \mathrm{Ra}$ and ${ }^{230} \mathrm{Th}$, because these radionuclides include ${ }^{222} \mathrm{Rn}$ in their decay chain. The dose from inhalation of radon decay 
products depends on the level of radon gas in the air, degree of equilibrium with its decay products and the breathing rate. Inhalation of ${ }^{14} \mathrm{C}$ in the gaseous form as ${ }^{14} \mathrm{CO}_{2}$ is a negligible contributor to the BDCF for ${ }^{14} \mathrm{C}$. Inhalation of particulate matter and aerosols generated by evaporative coolers is further discussed in this section.

\subsection{Inhalation of Particulate Matter}

Inhalation exposure is calculated in the biosphere model by using a time-budget method, where a receptor's time is spent in several mutually exclusive environments. Inhalation of particulate matter arising from resuspension of contaminated soil occurs in all receptor environments except when away from the contaminated area. A short summary of the environments and their characteristics with regard to the receptor follow:

- Active outdoors - receptor is outdoors conducting dust generating activities

- Inactive outdoors - receptor is outdoors conducting activities that do not resuspend soil

- Active indoors - receptor is awake indoors

- Asleep - receptor is sleeping

- Away - receptor is away from contaminated area.

Figure 6.2-28 shows the fractional contributions from these environments to the BDCF component that results from inhalation of airborne particulates. Inhalation exposure accrued in the active outdoors environment is by far a dominant contributor (the Excel file Detailed Pathway Analysis GW_MC.xls is the source of this and other figures in this section).

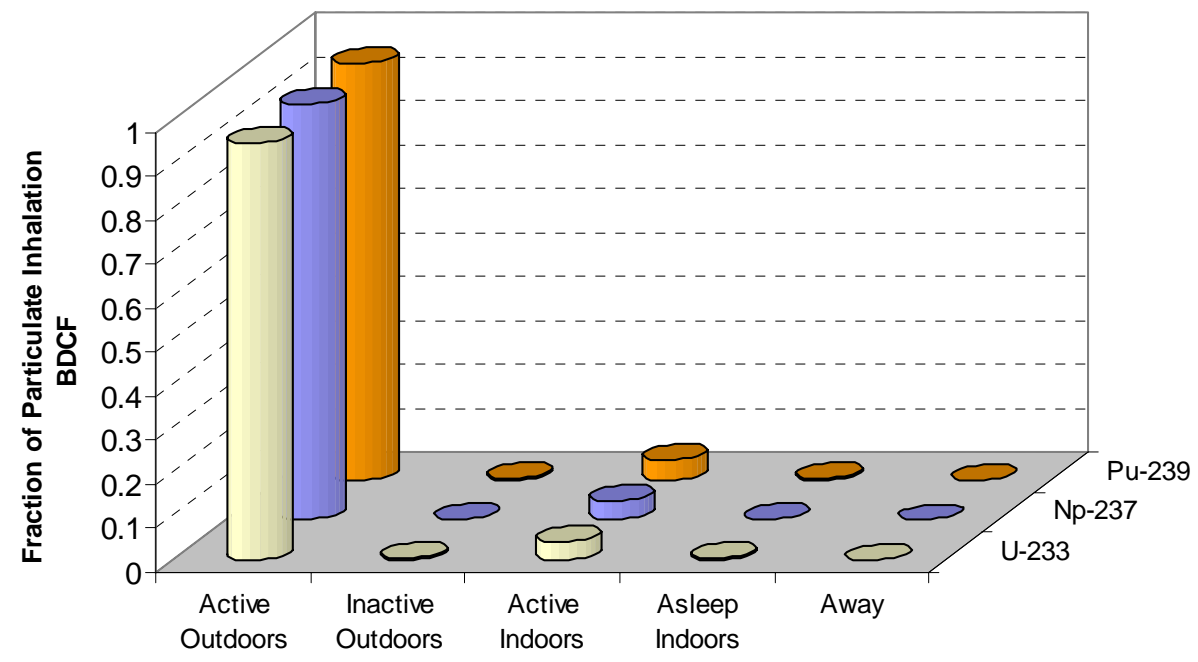

Source: Excel file Detailed Pathway Analysis GW_MC.xIs (Appendix A).

Figure 6.2-28. Average Fraction of Dose from Particulate Inhalation by Radionuclide and Environment

To explain the reasons behind the high inhalation exposure in the active outdoor environment and discuss the sources of uncertainty, the mathematical representation of the particulate inhalation submodel is described below. The inhalation dose from airborne particulates is calculated as (adopted from BSC 2004 [DIRS 169460], Equation 6.4.8-2) 


$$
D_{i n h, p}=D C F_{i n h} \sum_{n} C a_{n} B R_{n} \sum_{m}\left(P P_{m} t_{n, m}\right)
$$

where

$$
\begin{aligned}
& D_{i n h, p} \quad=\quad \text { annual dose from inhalation exposure to a radionuclide in resuspended } \\
& \text { particulates (Sv/yr) } \\
& D C F_{\text {inh }}=\text { dose conversion factor for inhalation }(\mathrm{Sv} / \mathrm{Bq}) \\
& \mathrm{Ca}_{n}=\text { activity concentration of a radionuclide in air for environment } n\left(\mathrm{~Bq} / \mathrm{m}^{3}\right) \\
& B R_{n} \quad=\text { breathing rate for environment } n\left(\mathrm{~m}^{3} / \mathrm{hr}\right) \\
& P P_{m} \quad=\quad \text { fraction of total population in population group } m \\
& t_{n, m}=\text { annual number of hours a population group } m \text { spends in environment } n \\
& \text { (hr/yr) }
\end{aligned}
$$

The dose from inhalation of particulate matter in a given receptor environment is calculated as a product of radionuclide concentration in air, breathing rate, and time spent in that environment.

The activity concentration in air, $C a_{n}$, is an environment-specific quantity that depends on the level of soil-disturbing and dust-generating activities that are conducted in an environment and on the level of increase of mass activity concentration of resuspended material relative to the mass activity concentration of the surface soil. These parameters were discussed in Section 6.2.4.2. Mass loading was developed based on measurements of resuspended particulate concentrations in environments or conditions analogous to those considered in the biosphere model (BSC 2004 [DIRS 169458], Section 6.1). The active outdoors environment is characterized by the highest mass loading levels of all receptor environment.

Inhalation exposure for an environment depends on the time spent in this environment by the receptor. Since the receptor for the biosphere model is a hypothetical individual representative of different population groups living in Amargosa Valley, the time spent in an environment is weighted by the population proportions for individual population group. Population groups are mutually exclusive fractions of the Amargosa Valley population that constitute the hypothetical receptor and are described in detail in the Characteristics of the Receptor for the Biosphere Model (BSC 2004 [DIRS 169671], Section 6.3.1). In Equation 6.2-11, the weighted time spent in an environment is represented by the product of $P P_{m}$ and $t_{n, m}$. Population proportions, $P P_{m}$, were developed from 2000 census data (BSC 2004 [DIRS 169671], Section 6.3.1). Time spent in an environment by a population group, $t_{n, m}$, was calculated based on 2000 census data for the residents of Amargosa Valley (BSC 2004 [DIRS 169671], Section 6.3.2).

Figure 6.2-29 shows the weighted time for all receptor environments. The receptor spends relatively few hours per day in the active outdoors environment and most time indoors. Despite this receptor behavior pattern, inhalation exposure in the active outdoor environment is dominant because of the high level of airborne particulates in that environment. 


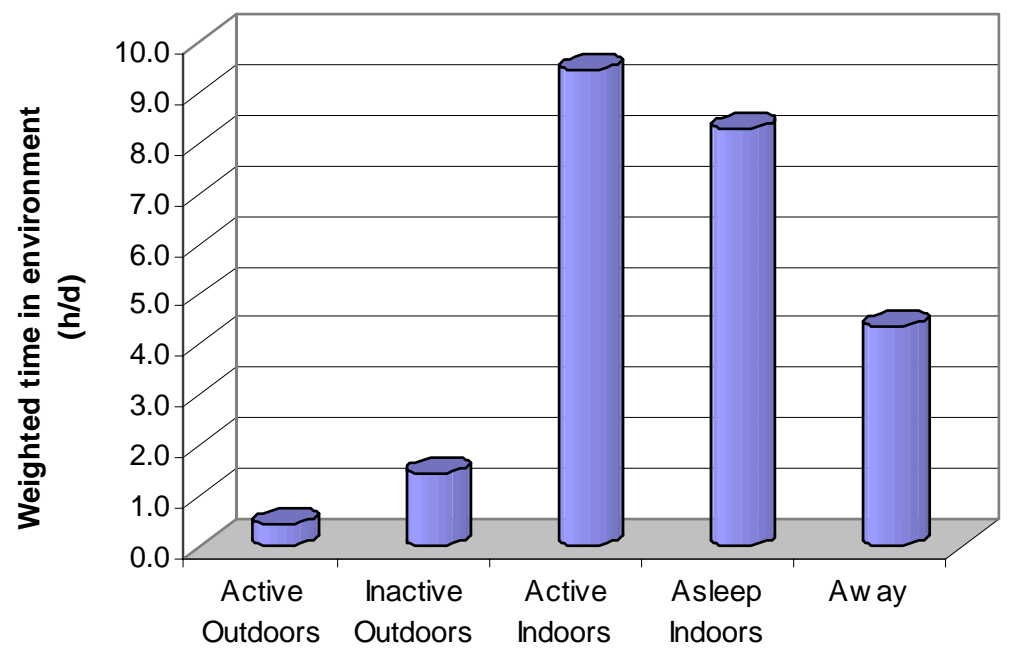

Source: Excel file Detailed Pathway Analysis GW_FC.xIs (Appendix A).

Figure 6.2-29. Average Weighted Time Spent in the Receptor Environments for the Groundwater Exposure Scenario

Another factor affecting radionuclide intake by inhalation, and thus inhalation dose, is the breathing rate. Breathing rate in the biosphere model is also environment-dependent and is highest in the active outdoor environment, as illustrated in Figure 6.2-30.

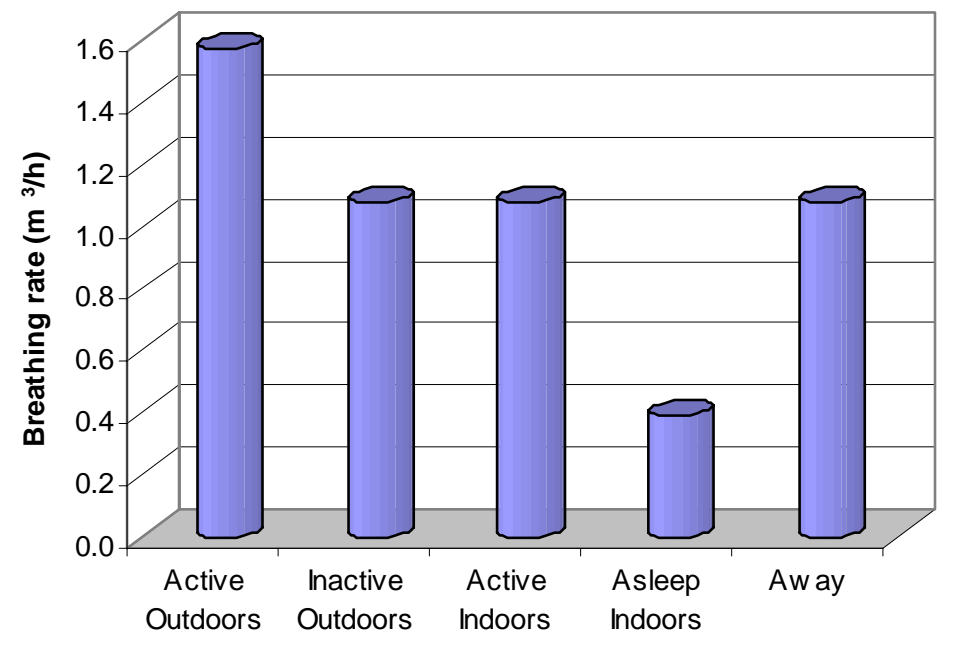

Source: Excel file Detailed Pathway Analysis GW_FC.xIs (Appendix A).

Figure 6.2-30. Breathing Rates in the Receptor Environments

Breathing rates for the receptor environments correspond to the activities and exercise levels expected in an environment and were adopted from the reference values reported in the International Commission on Radiological Protection Publication 66 (ICRP 1994 [DIRS 153705]), as described in Characteristics of the Receptor for the Biosphere Model (BSC 2004 [DIRS 169671], Section 6.3.3). 
The correlation statistics presented in Table 6.2-3 indicate that there are only a few receptor related parameters used in the calculation of the inhalation dose that affect the variance in BDCFs. One of these parameters is the time spent in the active outdoors environment by non-workers and commuters. These two group are by far the most common among Amargosa Valley residents, accounting, on average, for over 78 percent of the population (see Excel file Detailed Pathway Analysis GW_MC.xls in Appendix A). The times spent outdoors by these two groups are included in the calculation of the weighted time $\left(P P_{m} \times t_{n, m}\right.$ in Equation 6.2-11) and significantly influence its value. The dependence of the BDCFs for actinides on the value of the weighted time in the active outdoors environment is graphically shown in Figure 6.2-31. The BDCFs for ${ }^{233} \mathrm{U},{ }^{237} \mathrm{~Np}$, and ${ }^{239} \mathrm{Pu}$, used here as examples, depend relatively strongly on the value of this parameter, especially ${ }^{239} \mathrm{Pu}$.

\subsection{Inhalation of Aerosols Generated by Evaporative Coolers}

Inhalation of aerosols generated by evaporative coolers is another pathway leading to inhalation exposure. This type of inhalation exposure occurs only in the indoor environments, that is, active indoors and asleep, and only while evaporative coolers are being used. The importance if this pathway is greatly reduced for the future climate (Table 6.2-2).

The inhalation dose from airborne aerosols generated by evaporative coolers is calculated as (adopted from BSC 2004 [DIRS 169460], Equation 6.4.8-3)

$$
D_{\text {inh }, e}=D C F_{\text {inh }} C a_{e} f_{\text {cooler }} f_{\text {use }} \sum_{n \text { (indoor env. })} B R_{n}\left(\sum_{m} P P_{m} t_{n, m}\right)
$$

where

$$
\begin{aligned}
& \mathrm{Ca}_{e}=\text { activity concentration of a radionuclide in indoor air attributable to the } \\
& \text { evaporative cooler operation }\left(\mathrm{Bq} / \mathrm{m}^{3}\right) \\
& f_{\text {cooler }}=\text { fraction of houses with evaporative coolers (dimensionless) } \\
& f_{\text {use }} \quad=\text { annual evaporative cooler use factor (dimensionless) }
\end{aligned}
$$

The fraction of houses with evaporative coolers is a site-specific parameter that was developed from the results of a survey of Amargosa Valley residents. The value of the annual evaporative cooler use factor was based on local temperatures. The distributions of these parameters represent realistic, site-specific conditions (BSC 2004 [DIRS 169671, Section 6.3.4).

The parameters used to calculate the inhalation dose from aerosols generated by evaporative coolers contribute to the variance in the BDCFs for some radionuclides, particularly actinides. The parameter that account for the largest fraction of the BDCF variance is the evaporative cooler water transfer fraction, which was discussed in Section 6.2.4.2.1. Parameters that depend on the receptor behaviors, such as time spent indoors where exposure occurs, are not significant contributors to the BDCF variance (Table 6.2-3). 

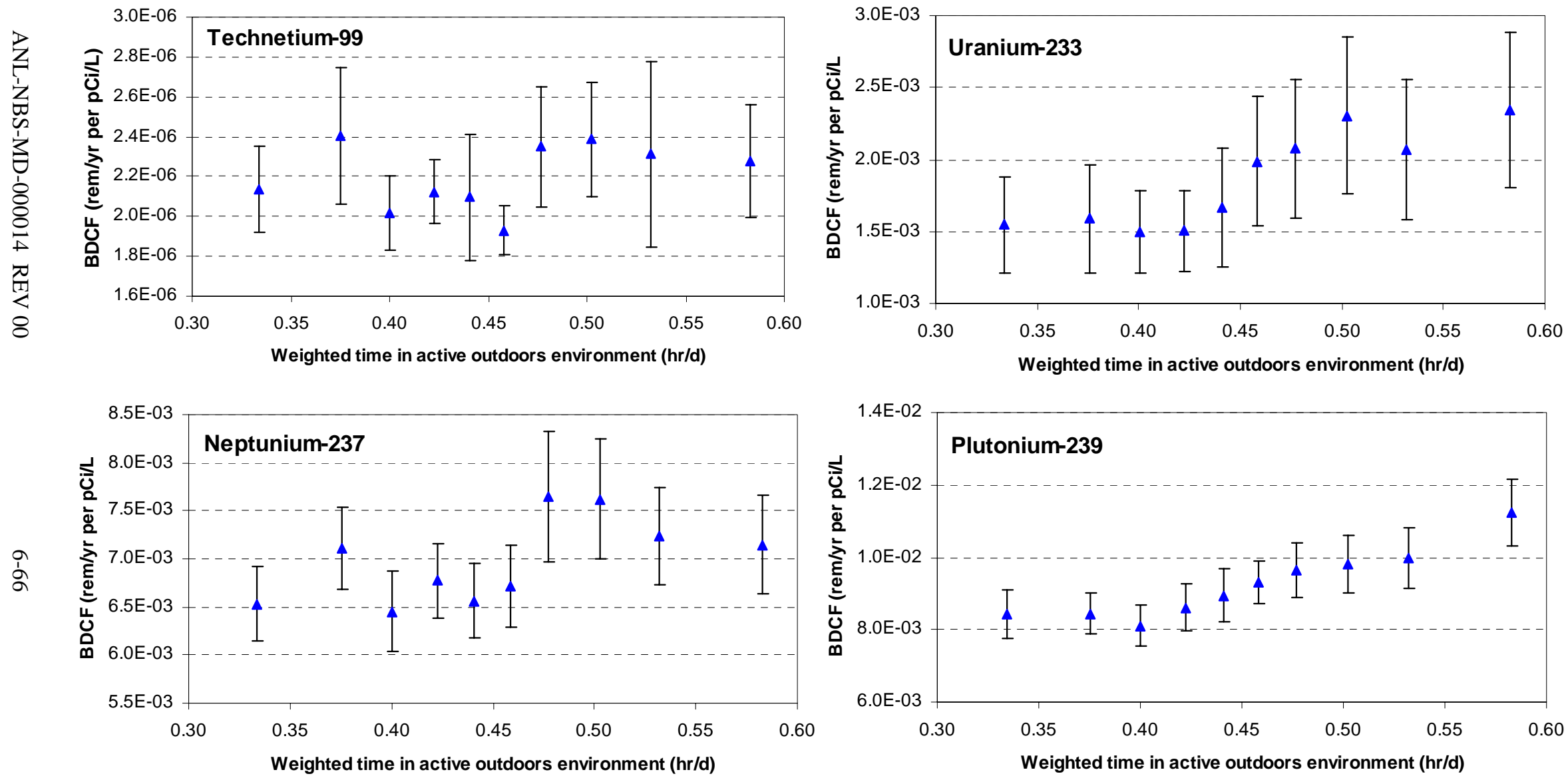

Source: Excel file Dependence of GW BDCFs on Inputs.xls (Appendix A).

NOTE: The triangles represent the mean of 100 values. The error bars represent the uncertainty range for the mean at the 95 percent uncertainty interval, calculated as 1.96 times the standard error of the mean. The outlier point with a high BDCF value for ${ }^{99} \mathrm{Tc}$ was removed to better show the trend in the BDCFs for this radionuclide as a function of time spent in an environment. 


\subsubsection{External Exposure}

External exposure is an important pathway for only a few radionuclides (see Table 6.2-1 and 6.2-2). The dose from external exposure depends on radionuclide concentrations in the soil (discussed in Section 6.2.4.1) and the duration of receptor exposure to the soil, modified by the building shielding factor, while indoors (BSC 2004 [DIRS 169460], Equation 6.4.7-1). There is little variability in this component because the receptor is assumed to be exposed to contaminated soil at all times, except for the time spent away by commuters (an average of 8 hours per day), and an average of 2 hours per day spent away by the other population groups.

\subsection{IDENTIFICATION OF IMPORTANT PATHWAYS, PROCESSES AND PARAMETERS FOR THE VOLCANIC ASH EXPOSURE SCENARIO}

This section uses results of the runs of the biosphere model for the groundwater exposure scenario included in DTN: MO0407MWDGSMFV.000 [DIRS 170856]. For deterministic calculations the input was obtained from the model input data files (DTNs: MO0403SPAAEIBM.002 [DIRS 169392]; MO0407SPAINEXI.002 [DIRS 170597]; MO0407SPASRPBM.002 [DIRS 170755]; MO0406SPAETPBM.002 [DIRS 170150]; MO0407SPACRBSM.002 [DIRS 170677]), as described in Section 4.1.

\subsubsection{Distributions of Biosphere Dose Conversion Factors}

This section evaluates the distributions of the BDCF components for the volcanic ash exposure scenario for radionuclides included in the biosphere model for this scenario, examines trends in the BDCFs, and evaluates the cause of these trends. Each run of the biosphere model for the volcanic ash exposure scenario for a given radionuclide produced 1,000 model realizations, with the realization results in the form of three BDCF components and the value of the critical thickness. These components are incorporated into the TSPA model using the following expression (adapted from BSC 2004 [DIRS 169460], Equation 6.5.8-2)

$$
B D C F\left(d_{a}, t\right)=B D C F_{e x t, i n g, R n}+\left(B D C F_{i n h, v} f(t)+B D C F_{i n h, p}\right) g\left(d_{a}\right)
$$

where

$$
\begin{aligned}
& B D C F\left(d_{a}, t\right) \quad=\quad \text { BDCF for the primary radionuclide for an ash depth } d_{a} \text { at time } t \\
& \text { following a volcanic eruption (Sv/yr per } \mathrm{Bq} / \mathrm{m}^{2} \text { ) } \\
& B D C F_{\text {ext,ing,Rn }} \quad=\text { BDCF for the primary radionuclide for non-inhalation pathways, } \\
& \text { that is, external exposure, ingestion, and inhalation of radon decay } \\
& \text { products (Sv/yr per } \mathrm{Bq} / \mathrm{m}^{2} \text { ) } \\
& B D C F_{\text {inh,v }} \quad=\text { BDCF for the primary radionuclide for short-term inhalation at } \\
& \text { post-volcanic level of mass loading in excess of nominal mass } \\
& \text { loading (Sv/yr per } \mathrm{Bq} / \mathrm{m}^{2} \text { ) } \\
& B D C F_{\text {inh }, p} \quad=\mathrm{BDCF} \text { for the primary radionuclide for long-term inhalation at } \\
& \text { nominal level of mass loading (Sv/yr per Bq } / \mathrm{m}^{2} \text { ) } \\
& f(t) \quad=\text { decay function describing reduction of mass loading with time } \\
& d_{a} \quad=\text { thickness of ash (m) }
\end{aligned}
$$




$$
g\left(d_{a}\right) \quad=\text { function of ash thickness, } d_{a} \text {, representing the fraction of total }
$$
activity that is available for resuspension.

The function of time, $f(t)$ in Equation 6.3-1, accounts for the reduction of mass loading in the years immediately following volcanic eruption and is expressed as (modified from BSC 2004 [DIRS 169458], Equation 6.3-1)

$$
f(t)=e^{-\lambda t}
$$

where

$\lambda \quad=$ mass loading decrease constant $(1 / \mathrm{yr})$

$t \quad=\quad$ time $(\mathrm{yr}) ; t=0$ is the first year after a volcanic eruption.

The function of ash thickness (BSC 2004 [DIRS 169460], Section 6.5.1.2), $g\left(d_{a}\right)$, is expressed as

$$
g\left(d_{a}\right)= \begin{cases}1 & \text { when } d_{a}<d_{c} \\ \frac{d_{c}}{d_{a}} & \text { when } d_{a} \geq d_{c}\end{cases}
$$

where $d_{c}$ is the critical thickness of the ash layer. The critical thickness is defined as the thickness of the surface soil (ash) layer that is available for resuspension

Each model realization used a different set of input parameter values. The three BDCF components generated by the biosphere model are the ingestion-radon-external exposure component, the short-term inhalation component, and the long-term inhalation component. The ingestion-external-radon component accounts for contributions from all ingestion pathways, including ingestion of locally produced food and inadvertent soil ingestion; external exposure; and inhalation exposure to radon decay products. The short-term inhalation component represents exposure to airborne particulate matter during the period of increased concentrations of resuspended particulates following volcanic eruption. This component is multiplied by the time-dependent function in the TSPA because mass loading will decrease after a volcanic eruption. The long-term inhalation component represents inhalation of resuspended particulates under nominal conditions (i.e., when mass loading is not elevated as the result of a volcanic eruption). One set of BDCFs was calculated for all climates. The BDCF statistics are summarized in the Disruptive Event Biosphere Dose Conversion Factor Analysis (BSC 2004 [DIRS 167287], Tables 6.2-1 to 6.2-3 for the external-ingestion-radon component, short-term inhalation component, and the long-term inhalation component, respectively).

Figures 6.3-1 to 6.3-3 show the ranges of BDCF components for all primary radionuclides included in the biosphere model for the volcanic ash scenario, including their mean and median values, minima and maxima, and the $5^{\text {th }}$ and $95^{\text {th }}$ percentiles. The figures were generated in the Excel workbook VA BDCF Variability Plots.xls (Appendix A). The variance in the BDCFs is a result of the input parameter variability and uncertainty that is propagated into the model output. 


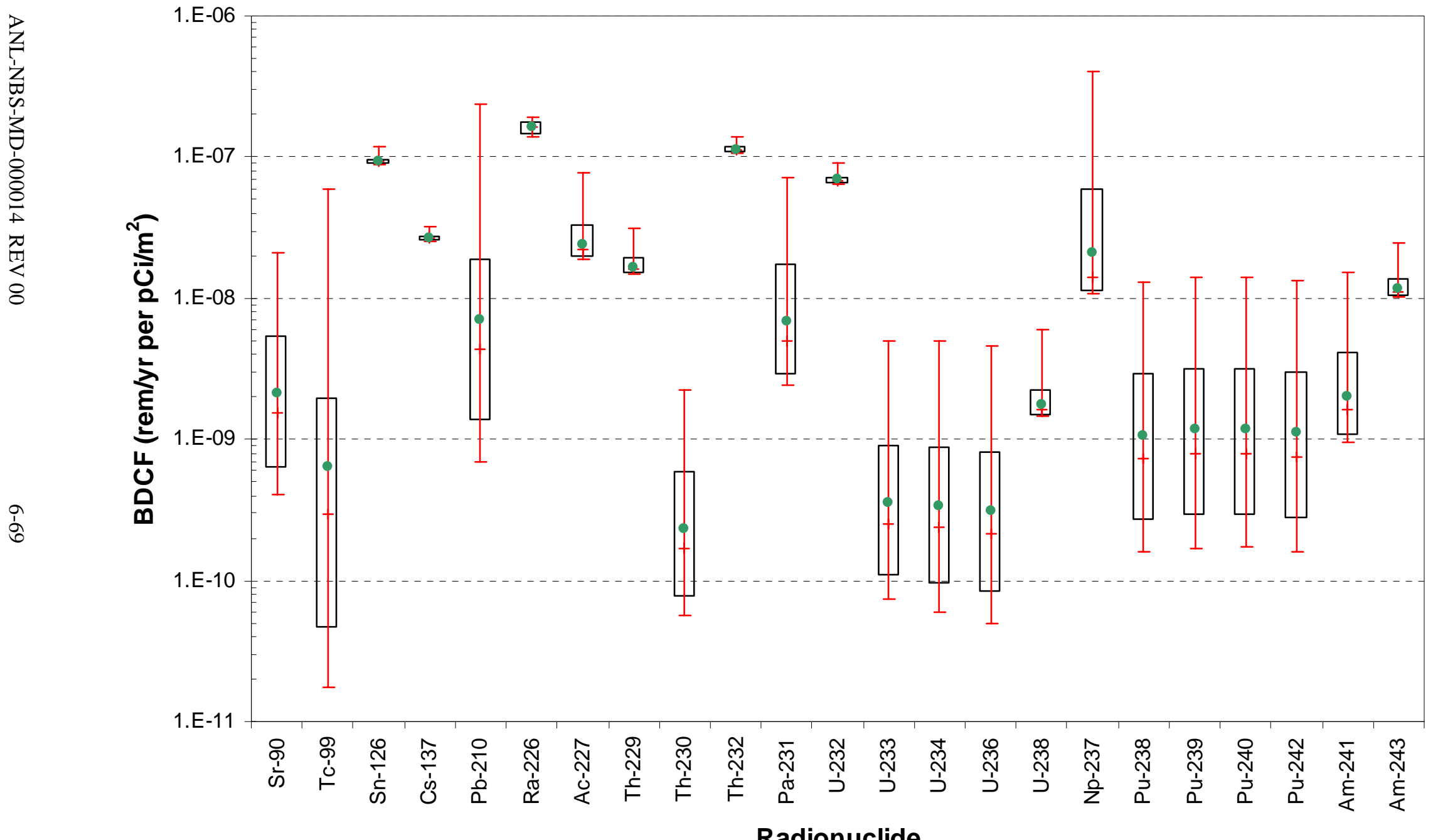

Source: Excel file VA BDCF Variability Plots.xIs (Appendix A).

NOTE: Boxes represent $5^{\text {th }}$ to $95^{\text {th }}$ percentile range. The vertical solid line represents the range and the tick mark on the line is the median. Circle represents the mean BDCF.

Figure 6.3-1. Distributions of the Ingestion-Radon-External Exposure Component of the BDCFs for the Volcanic Ash Exposure Scenario 


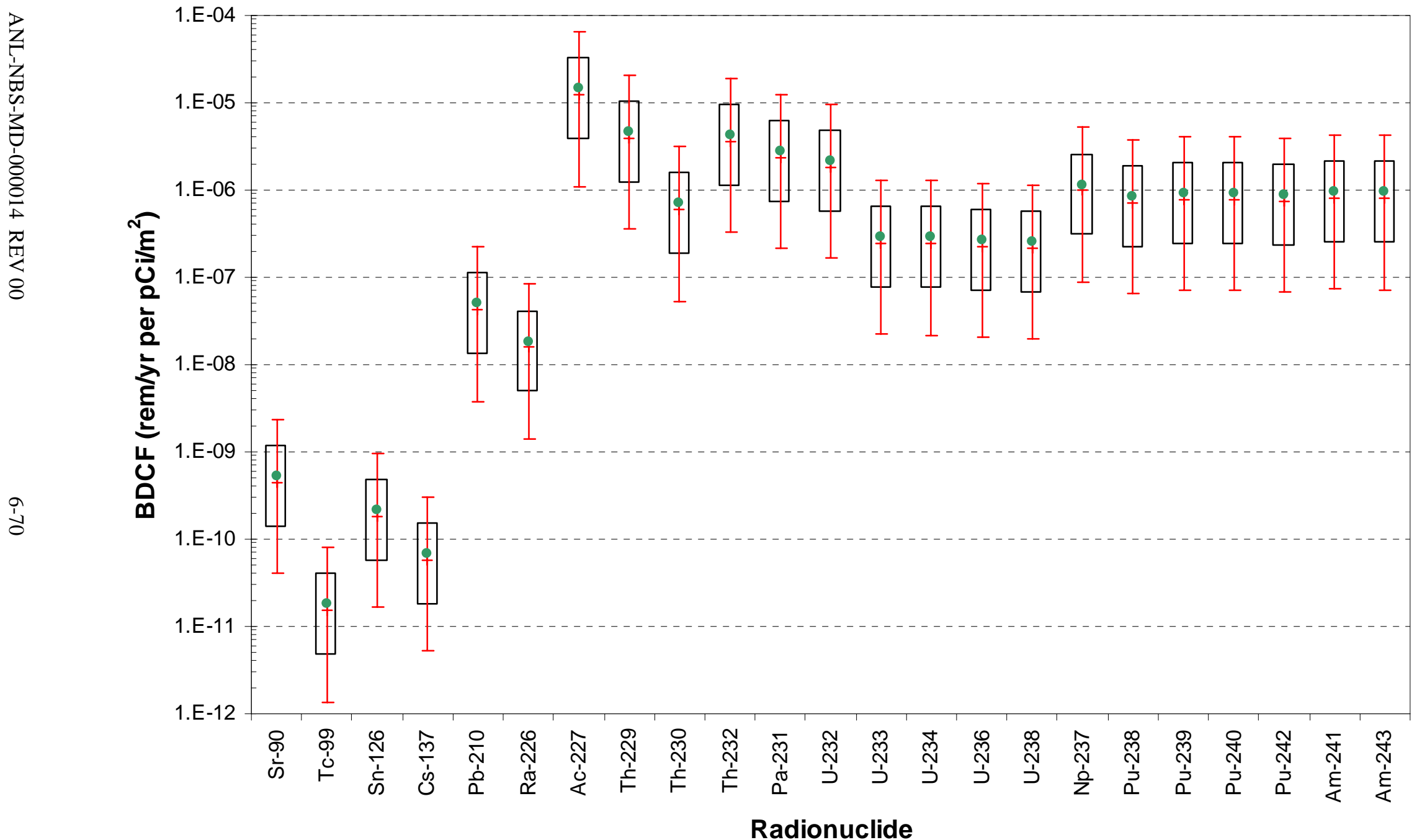

Source: Excel file VA BDCF Variability Plots.xIs (Appendix A).

NOTE: Boxes represent $5^{\text {th }}$ to $95^{\text {th }}$ percentile range. The vertical solid line represents the range and the tick mark on the line is the median. Circle represents the mean BDCF.

Figure 6.3-2. Distributions of the Short-Term Inhalation Component of the BDCFs for the Volcanic Ash Exposure Scenario 


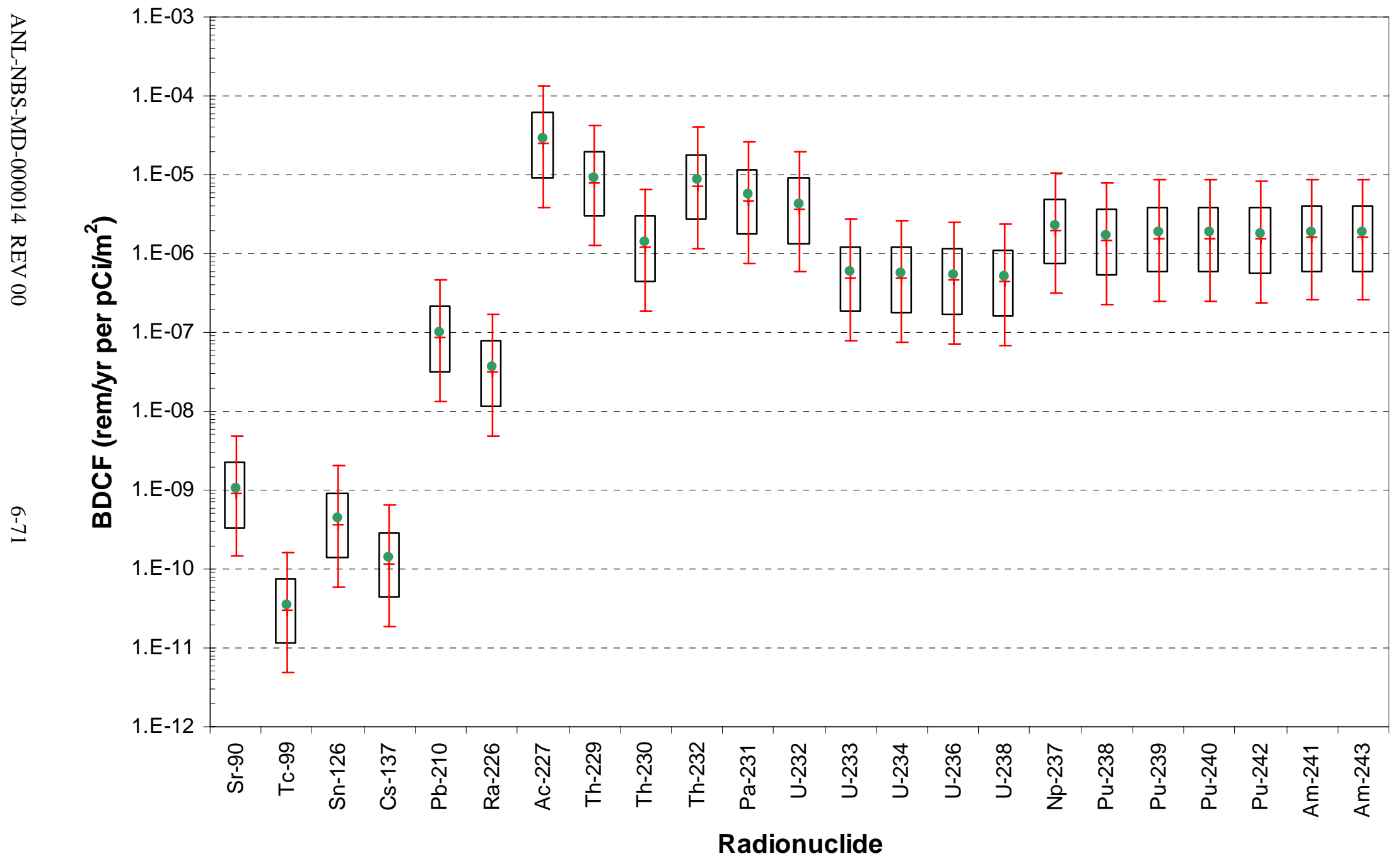

Source: Excel file VA BDCF Variability Plots.xIs described in Appendix A.

NOTE: Boxes represent $5^{\text {th }}$ to $95^{\text {th }}$ percentile range. The vertical solid line represents the range and the tick mark on the line is the median. Circle represents the mean BDCF.

Figure 6.3-3. Distributions of the Long-Term Inhalation Component of the BDCFs for the Volcanic Ash Exposure Scenario 
A number of trends can be observed in the BDCF values. The variability in the ingestion-radon-external exposure BDCF component differs greatly among radionuclides. The $95^{\text {th }}$ to $5^{\text {th }}$ percentile ratio vary from 1.1 to 13.7 except for ${ }^{99}$ Tc (the ratio for this radionuclide is 42.3). The maximum values are higher than the minima by less than two orders of magnitude, except for ${ }^{99} \mathrm{Tc}$ and ${ }^{210} \mathrm{~Pb}$. There are a few radionuclides that have a very narrow distribution for the ingestion-radon-external exposure BDCF component. These are the radionuclides, such as ${ }^{126} \mathrm{Sn},{ }^{137} \mathrm{Cs},{ }^{232} \mathrm{Th}$, and ${ }^{232} \mathrm{U}$, that have a large fraction of the BDCFs attributable to the external exposure pathway. External exposure may be due to the decay products of these radionuclides.

For the short-term and long term inhalation components, BDCF distributions differ among radionuclides only by the value of the inhalation dose conversion factor, which is a fixed parameter, and functions here as a scaling factor. For all short-term BDCF components, the ratio of the $95^{\text {th }}$ to $5^{\text {th }}$ percentile is 8.4 and the maximum to minimum ratio is 58.5 . The corresponding values for the long-term inhalation component are 6.7 and 34.3, respectively.

\subsubsection{Summary of Pathway Analysis}

The pathway contributions to the mean BDCF for the volcanic ash exposure scenario and the present-day climate are summarized in the Disruptive Event Biosphere Dose Conversion Factor Analysis (BSC 2004 [DIRS 167287], Table 6.2-7). These results are reproduced in Table 6.3-1. The differences between the volcanic ash scenario BDCFs for the present-day and future climates are insignificant (BSC 2004 [DIRS 167287], Section 6.2.5).

To calculate the annual dose, the BDCF components are combined in the TSPA model with the time dependent source term and ash thickness information. Therefore, the BDCF pathway contributions listed in Table 6.3-1 refer to specific conditions. Here they are presented for the point-in-time and ash-layer-thickness conditions, when the values of parameters $t$ and $d_{a}$ in Equations 6.3-1 to 6.3-3 are constant. From Equations 6.3-1 to 6.3-3, when $t=0$ (i.e., for the initial values of ash deposition and before the mass loading decrease occurs) and $d_{a} \leq d_{c}$ (i.e., all deposited activity can become resuspended), then

$$
B D C F\left(d_{a}, t\right)=B D C F_{e x t, i n g, R n}+B D C F_{i n h, v}+B D C F_{i n h, p}
$$

The biosphere model for the volcanic ash exposure scenario explicitly addresses 12 exposure pathways. The pathways related to groundwater contamination-such as water consumption, consumption of aquatic food, and inhalation of aerosols from evaporative coolers-are not included because contamination of water in modeled in the groundwater exposure scenario. Pathway analysis was conducted to determine the relative importance of individual exposure pathways in terms of their contributions to BDCFs for various radionuclides. Percent contributions to the BDCF were calculated using the mean values of the BDCFs. 
Table 6.3-1. Exposure Pathway Contributions (Percent) for the Mean Volcanic Ash Exposure Scenario BDCFs for the Present-Day Climate

\begin{tabular}{|c|c|c|c|c|c|c|c|c|c|c|c|c|c|}
\hline \multirow[b]{2}{*}{$\begin{array}{l}\text { Radio- } \\
\text { nuclide }\end{array}$} & \multirow[b]{2}{*}{ External } & \multicolumn{3}{|c|}{ Inhalation } & \multicolumn{9}{|c|}{ Ingestion } \\
\hline & & Short & Long & Radon & $\begin{array}{l}\text { Leafy } \\
\text { Veget. }\end{array}$ & $\begin{array}{l}\text { Other } \\
\text { Veget. }\end{array}$ & Fruit & Grain & Meat & Milk & Poultry & Eggs & Soil \\
\hline Sr-90 & 7.2 & 14.4 & 28.7 & 0.0 & 11.7 & 9.0 & 12.2 & 0.9 & 5.6 & 6.9 & 0.1 & 2.7 & 0.8 \\
\hline Tc-99 & 0.3 & 2.6 & 5.1 & 0.0 & 20.1 & 4.4 & 17.2 & 0.9 & 7.0 & 25.7 & 0.2 & 16.4 & 0.0 \\
\hline Sn-126 & 99.1 & 0.2 & 0.5 & 0.0 & 0.0 & 0.0 & 0.0 & 0.0 & 0.2 & 0.0 & 0.0 & 0.0 & 0.0 \\
\hline Cs-137 & 98.1 & 0.3 & 0.5 & 0.0 & 0.0 & 0.0 & 0.1 & 0.0 & 0.3 & 0.2 & 0.2 & 0.2 & 0.0 \\
\hline $\mathrm{Pb}-210$ & 0.1 & 31.9 & 63.6 & 0.0 & 0.5 & 0.2 & 1.0 & 0.1 & 0.1 & 0.1 & 0.0 & 1.5 & 0.9 \\
\hline Ra-226 & 36.5 & 8.5 & 17.0 & 37.5 & 0.1 & 0.1 & 0.1 & 0.0 & 0.0 & 0.0 & 0.0 & 0.0 & 0.1 \\
\hline Ac-227 & 0.0 & 33.4 & 66.6 & 0.0 & 0.0 & 0.0 & 0.0 & 0.0 & 0.0 & 0.0 & 0.0 & 0.0 & 0.0 \\
\hline Th-229 & 0.1 & 33.3 & 66.5 & 0.0 & 0.0 & 0.0 & 0.0 & 0.0 & 0.0 & 0.0 & 0.0 & 0.0 & 0.0 \\
\hline Th-230 & 0.0 & 33.4 & 66.6 & 0.0 & 0.0 & 0.0 & 0.0 & 0.0 & 0.0 & 0.0 & 0.0 & 0.0 & 0.0 \\
\hline Th-232 & 0.9 & 33.1 & 66.0 & 0.0 & 0.0 & 0.0 & 0.0 & 0.0 & 0.0 & 0.0 & 0.0 & 0.0 & 0.0 \\
\hline Pa-231 & 0.0 & 33.4 & 66.6 & 0.0 & 0.0 & 0.0 & 0.0 & 0.0 & 0.0 & 0.0 & 0.0 & 0.0 & 0.0 \\
\hline U-232 & 1.0 & 33.0 & 65.9 & 0.0 & 0.0 & 0.0 & 0.0 & 0.0 & 0.0 & 0.0 & 0.0 & 0.0 & 0.0 \\
\hline U-233 & 0.0 & 33.4 & 66.6 & 0.0 & 0.0 & 0.0 & 0.0 & 0.0 & 0.0 & 0.0 & 0.0 & 0.0 & 0.0 \\
\hline U-234 & 0.0 & 33.4 & 66.6 & 0.0 & 0.0 & 0.0 & 0.0 & 0.0 & 0.0 & 0.0 & 0.0 & 0.0 & 0.0 \\
\hline U-235 & 0.0 & 33.4 & 66.6 & 0.0 & 0.0 & 0.0 & 0.0 & 0.0 & 0.0 & 0.0 & 0.0 & 0.0 & 0.0 \\
\hline U-236 & 0.2 & 33.3 & 66.5 & 0.0 & 0.0 & 0.0 & 0.0 & 0.0 & 0.0 & 0.0 & 0.0 & 0.0 & 0.0 \\
\hline Np-237 & 0.3 & 33.2 & 66.2 & 0.0 & 0.0 & 0.0 & 0.2 & 0.0 & 0.0 & 0.0 & 0.0 & 0.0 & 0.0 \\
\hline Pu-238 & 0.0 & 33.4 & 66.6 & 0.0 & 0.0 & 0.0 & 0.0 & 0.0 & 0.0 & 0.0 & 0.0 & 0.0 & 0.0 \\
\hline Pu-239 & 0.0 & 33.4 & 66.6 & 0.0 & 0.0 & 0.0 & 0.0 & 0.0 & 0.0 & 0.0 & 0.0 & 0.0 & 0.0 \\
\hline Pu-240 & 0.0 & 33.4 & 66.6 & 0.0 & 0.0 & 0.0 & 0.0 & 0.0 & 0.0 & 0.0 & 0.0 & 0.0 & 0.0 \\
\hline Pu242 & 0.0 & 33.4 & 66.6 & 0.0 & 0.0 & 0.0 & 0.0 & 0.0 & 0.0 & 0.0 & 0.0 & 0.0 & 0.0 \\
\hline Am-241 & 0.0 & 33.4 & 66.6 & 0.0 & 0.0 & 0.0 & 0.0 & 0.0 & 0.0 & 0.0 & 0.0 & 0.0 & 0.0 \\
\hline Am-243 & 0.4 & 33.2 & 66.3 & 0.0 & 0.0 & 0.0 & 0.0 & 0.0 & 0.0 & 0.0 & 0.0 & 0.0 & 0.0 \\
\hline
\end{tabular}

Source: BSC 2004 [DIRS 167287], Table 6.2-7.

NOTE: The pathway contributions are for the conditions when $t=0$ (i.e., for the initial values of ash deposition and before the mass loading decrease occurs) and $d_{a} \leq d_{c}$ (i.e., all deposited activity can become resuspended). 
Figure 6.3-4 shows the average pathway contributions from Table 6.3-1 for several selected radionuclides (Excel file Detailed Pathway Analysis VA.xls in Appendix A). The selection includes the radionuclides that were identified as important in previous TSPA efforts, such as ${ }^{90} \mathrm{Sr},{ }^{137} \mathrm{Cs},{ }^{237} \mathrm{~Np},{ }^{239} \mathrm{Pu}$, and ${ }^{241} \mathrm{Am}$ (CRWMS M\&O 2000 [DIRS 153246], Figure 4.2-2). Radon-226 was added to the list as an example of a radionuclide with a notably different composition of pathway contributions.

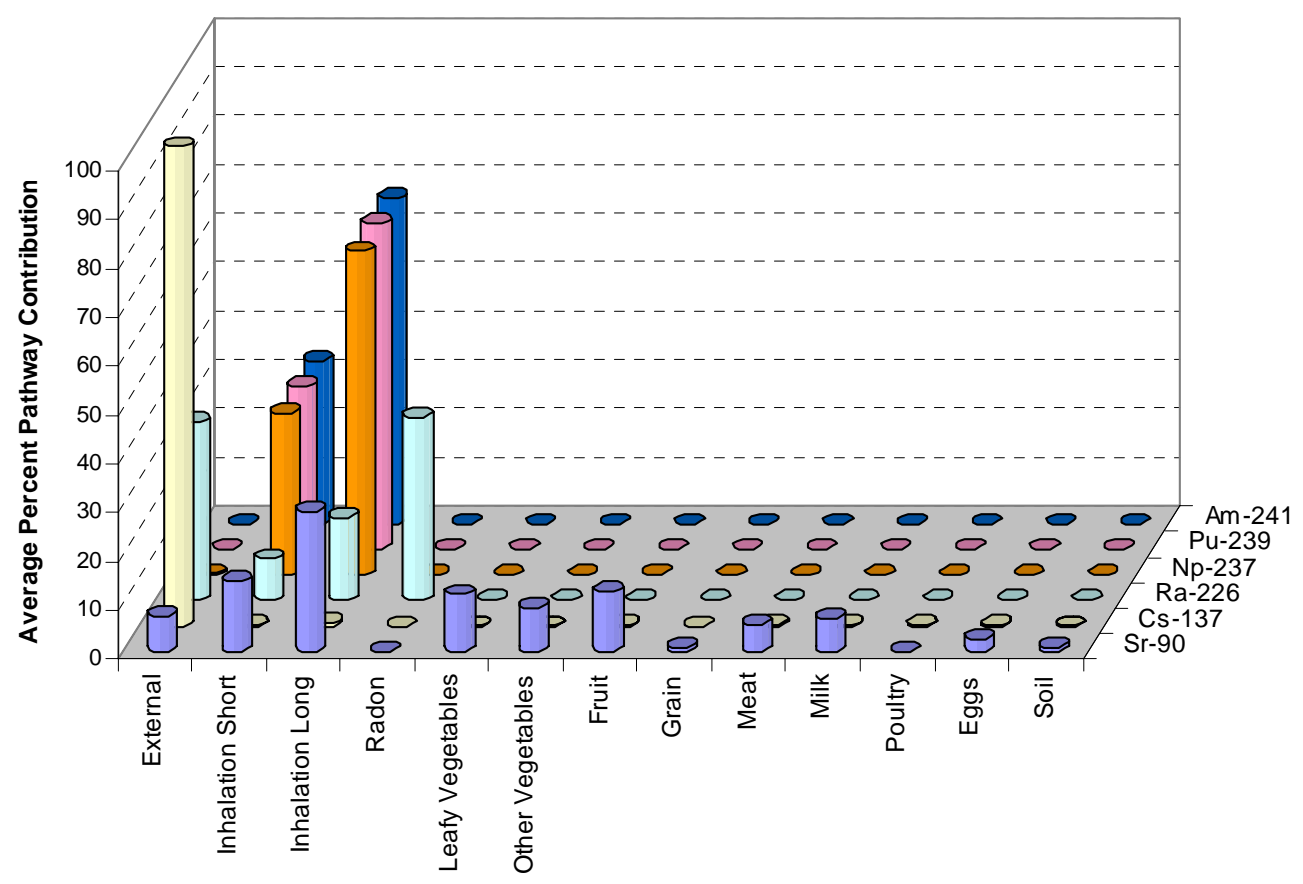

Figure 6.3-4. Average Percent BDCF Pathway Contributions for the Volcanic Ash Exposure Scenario for Time $=0$ and Ash Thickness Equal to or Less than Critical Thickness for Selected Radionuclides

If the ash thickness is greater than the critical thickness, the pathway composition changes from that shown in Table 6.3-1. If the ash thickness is 10 times that of the critical thickness, then the contribution of the inhalation BDCF components is reduced in proportion to $d_{c} / d_{s}$, that is, by a factor of 10. The pathway contributions for $t=0$ are illustrated in Figure 6.3-5. Even though the activity available for resuspension is 10 times less, the inhalation pathway still dominates for the actinides. When the level of dust in air returns to the pre-eruption level, the short-term inhalation component no longer contributes to the all-pathway dose. 


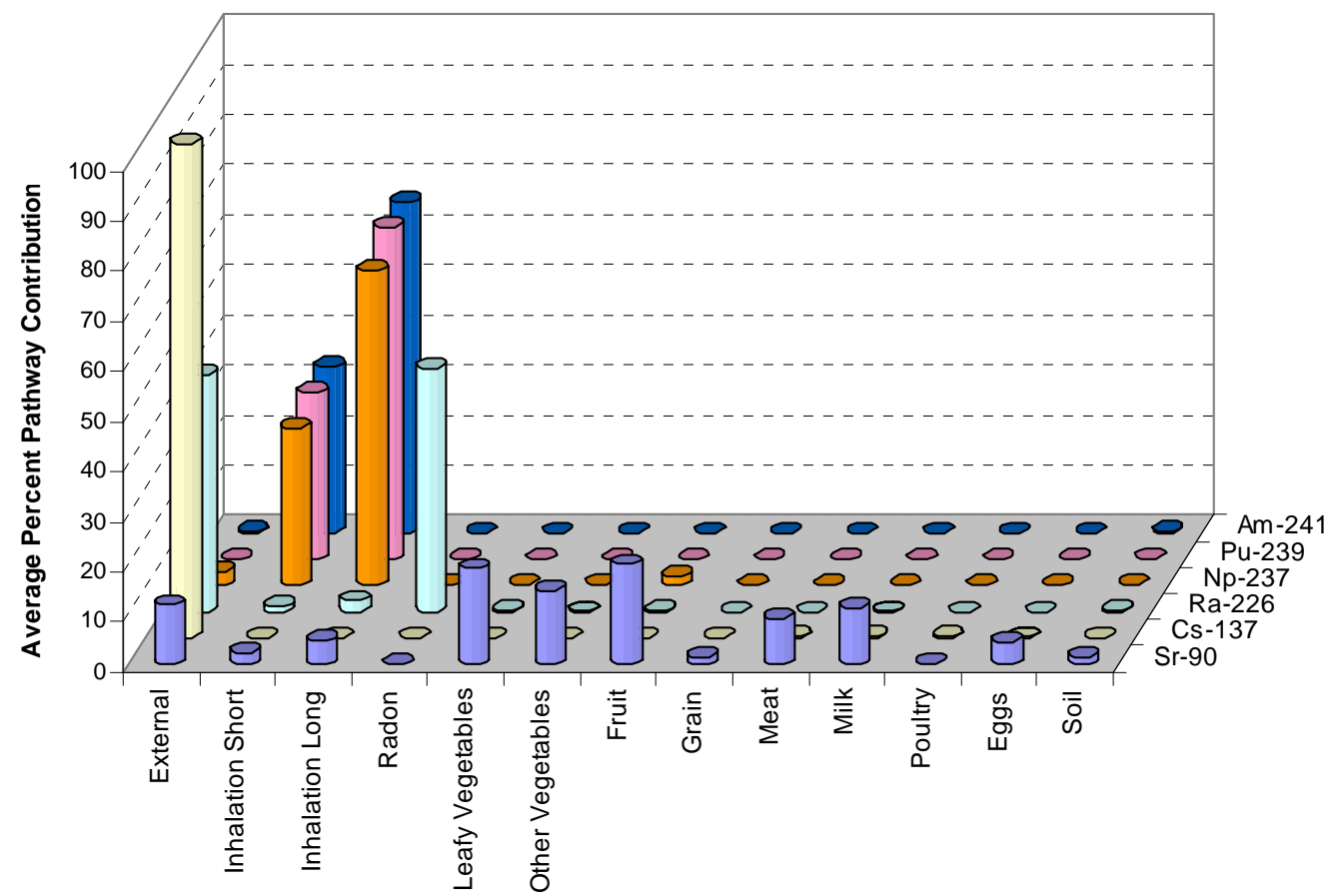

Source of both figures on this page: Excel file Detailed Pathway Analysis VA.xIs (Appendix A).

Figure 6.3-5. Average Percent BDCF Pathway Contributions for the Volcanic Ash Exposure Scenario for Time $=0$ and Ash Thickness 10 Times Greater Than Critical Thickness for Selected Radionuclides

The pathway contributions for ${ }^{90} \mathrm{Sr}$ and ${ }^{99} \mathrm{Tc}$ are diverse, and there is not a dominant contributor. The ingestion pathways are, overall, more important for ${ }^{99} \mathrm{Tc}-99$ than they are for ${ }^{90} \mathrm{Sr}$. For ${ }^{137} \mathrm{Cs}$, external exposure accounts for 98 percent of the dose. The BDCF for ${ }^{226} \mathrm{Ra}$ includes a large contribution from exposure to radon decay products (37.5 percent), as well as from inhalation (25.5 percent) and external exposure (36.5 percent). Ingestion is an unimportant exposure pathway for ${ }^{226} \mathrm{Ra}$. The dose for primary radionuclides with atomic numbers greater than 88 arises from the short- and long-term inhalation. The other pathways are negligible (Table 6.3-1).

The results of previous TSPA assessments indicate that, except for the initial few hundred years postclosure, the expected dose from a volcanic eruption is primarily due to the transuranics (CRWMS M\&O 2000 [DIRS 153246], Figure 4.2-2). The following analysis concentrates on a few selected transuranics: ${ }^{241} \mathrm{Am},{ }^{239} \mathrm{Pu},{ }^{240} \mathrm{Pu}$ and ${ }^{237} \mathrm{~Np}$. For these and other transuranics, BDCF pathway contributions are nearly identical (Table 6.3-1), with the short-term inhalation accounting for about one-third and the long-term inhalation accounting for about two-thirds of the BDCF the first year following an eruption.

\subsubsection{Sources of Uncertainty in the Biosphere Dose Conversion Factors}

The source of variance in the BDCF values (see Figures 6.3-1 to 6.3-3) is the uncertainty and variability in the values of the input parameters for the biosphere model. This section discusses the degree to which selected input parameters influence the BDCFs. This was quantified by calculating rank correlation coefficients. A correlation coefficient is a number between -1 and 1 that measures the degree to which two variables are linearly related. 
Correlation coefficients for the stochastic model input parameters and BDCF components for the volcanic ash exposure scenario were calculated for the selected radionuclides (see Excel file $V A$ Correlations.xls in Appendix A). Of the selected radionuclides considered in Section 6.3.2, ${ }^{90} \mathrm{Sr}$, ${ }^{99} \mathrm{Tc}$, and ${ }^{137} \mathrm{Cs}$ have a significant BDCF component from the pathways other than the inhalation of particulate matter. Therefore, the correlation coefficients for the ingestion-radon-external exposure pathways were calculated for these radionuclides only and are presented in Table 6.3-2 (see Excel file VA Correlations.xls in Appendix A). Only those correlations that are non-zero at the 99 percent confidence interval (absolute value of the correlation coefficient equal or greater than 0.0812) are shown in the table, plus the next correlation that is below this threshold (see Section 6.2.3.2 for calculation of the statistically significant value). The list includes the "false" correlations that were above the threshold value (marked with an “a”), as explained in Section 6.2.3.2.

Table 6.3-2 Correlation Coefficients for Input Parameters and the Ingestion-Radon-External Exposure Component of Biosphere Dose Conversion Factors for the Volcanic Ash Exposure Scenario

\begin{tabular}{|c|c|c|c|}
\hline Radionuclide & Parameter & $\begin{array}{l}\text { Correlation } \\
\text { Coefficient }\end{array}$ & $\begin{array}{c}\text { Correlation } \\
\text { Coefficient Squared }\end{array}$ \\
\hline \multirow[t]{16}{*}{ Strontium-90 } & Strontium partition coefficient $\left(\mathrm{K}_{\mathrm{d}}\right)$ & -0.672 & 0.451 \\
\hline & Strontium transfer factor for leafy vegetables & 0.631 & 0.398 \\
\hline & Strontium transfer factor for forage & 0.628 & 0.394 \\
\hline & Strontium transfer factor for fruit & 0.616 & 0.379 \\
\hline & Strontium transfer factor for other vegetables & 0.583 & 0.340 \\
\hline & Strontium transfer factor for grain & 0.544 & 0.296 \\
\hline & Surface soil depth & -0.529 & 0.280 \\
\hline & Strontium transfer coefficient for meat & 0.153 & 0.024 \\
\hline & Dry to wet ratio for leafy vegetables & 0.117 & 0.014 \\
\hline & Soil density & -0.116 & 0.013 \\
\hline & Dry to wet ratio for fruit & 0.115 & 0.013 \\
\hline & Strontium transfer coefficient for eggs & 0.113 & 0.013 \\
\hline & Critical thickness & 0.092 & 0.009 \\
\hline & Dry to wet ratio for other vegetables & 0.086 & 0.007 \\
\hline & Neptunium transfer coefficient for milk ${ }^{a}$ & -0.082 & 0.007 \\
\hline & Population fraction, commuters & 0.080 & 0.006 \\
\hline \multirow[t]{10}{*}{ Technetium-99 } & Technetium partition coefficient $\left(\mathrm{K}_{\mathrm{d}}\right)$ & -0.764 & 0.584 \\
\hline & Technetium transfer factor for leafy vegetables & 0.696 & 0.485 \\
\hline & Technetium transfer facto for forage & 0.683 & 0.466 \\
\hline & Technetium transfer factor for grain & 0.675 & 0.455 \\
\hline & Technetium transfer factor for fruit & 0.674 & 0.454 \\
\hline & Technetium transfer factor for other vegetables & 0.596 & 0.355 \\
\hline & Soil depth & -0.390 & 0.152 \\
\hline & Technetium transfer coefficient for milk & 0.178 & 0.032 \\
\hline & Dry to wet ratio for leafy vegetables & 0.086 & 0.007 \\
\hline & Cesium transfer factor for leafy vegetables ${ }^{a}$ & 0.079 & 0.006 \\
\hline
\end{tabular}


Table 6.3-2 Correlation Coefficients for the Input Parameters and Ingestion-Radon-External Exposure Component of Biosphere Dose Conversion Factors for the Volcanic Ash Exposure Scenario (Continued)

\begin{tabular}{|c|c|c|c|}
\hline Radionuclide & Parameter & $\begin{array}{l}\text { Correlation } \\
\text { Coefficient }\end{array}$ & $\begin{array}{c}\text { Correlation } \\
\text { Coefficient Squared }\end{array}$ \\
\hline \multirow[t]{24}{*}{ Cesium-137 } & Population fraction, outdoor workers & 0.372 & 0.139 \\
\hline & Time spent away, indoor workers & -0.350 & 0.123 \\
\hline & Time spent away, non-workers & -0.320 & 0.102 \\
\hline & Population fraction, commuters & -0.312 & 0.097 \\
\hline & $\begin{array}{l}\text { Time spend in inactive outdoors environment, } \\
\text { indoor workers }\end{array}$ & 0.278 & 0.078 \\
\hline & $\begin{array}{l}\text { Time spend in inactive outdoors environment, non- } \\
\text { workers }\end{array}$ & 0.203 & 0.041 \\
\hline & Soil depth & -0.197 & 0.039 \\
\hline & Cesium transfer factor for forage & 0.185 & 0.034 \\
\hline & Cesium partition coefficient $\left(\mathrm{K}_{\mathrm{d}}\right)$ & -0.171 & 0.029 \\
\hline & Cesium transfer factor for grain & 0.165 & 0.027 \\
\hline & $\begin{array}{l}\text { Time spend in active outdoors environment, non- } \\
\text { workers }\end{array}$ & 0.155 & 0.024 \\
\hline & Cesium transfer factor for fruit & 0.152 & 0.023 \\
\hline & Cesium transfer coefficient for poultry & 0.149 & 0.022 \\
\hline & $\begin{array}{l}\text { Time spend in active outdoors environment, indoor } \\
\text { workers }\end{array}$ & 0.143 & 0.021 \\
\hline & Cesium transfer factor for leafy vegetables & 0.134 & 0.018 \\
\hline & Deposition velocity & 0.115 & 0.013 \\
\hline & Protactinium transfer coefficient for milk ${ }^{a}$ & -0.109 & 0.012 \\
\hline & Time spent away, commuters & -0.104 & 0.011 \\
\hline & Cesium transfer factor for other vegetables & 0.101 & 0.010 \\
\hline & Cesium transfer coefficient for eggs & 0.095 & 0.009 \\
\hline & Cesium transfer coefficient for meat & 0.092 & 0.008 \\
\hline & $\begin{array}{l}\text { Time spend in inactive outdoors environment, } \\
\text { commuters }\end{array}$ & 0.086 & 0.007 \\
\hline & $\begin{array}{l}\text { Enhancement factor for inactive outdoors } \\
\text { environments }\end{array}$ & -0.086 & 0.007 \\
\hline & Cesium transfer coefficient for milk & 0.078 & 0.006 \\
\hline
\end{tabular}

Source: Excel file VA Correlations.xIs (Appendix A).

${ }^{a}$ false correlation

For ${ }^{90} \mathrm{Sr}$ and ${ }^{99} \mathrm{Tc}$, the highest correlations for the ingestion-radon-external exposure BDCF component are with the parameters that control transfer of radioactivity to crops and retention of radionuclides in the surface soil. For these radionuclides, there is a strong a positive correlation of BDCFs with the soil-to-pant transfer factors and a negative correlation with $\mathrm{K}_{\mathrm{d}} \mathrm{s}$. Correlation with the $K_{d}$ is an artifact of having $K_{d} s$ and transfer factors negatively correlated in the model because leaching is not a radionuclide removal mechanism that is included in the model for the volcanic ash exposure scenario. 
The variance in the ingestion-radon-external exposure BDCF component for ${ }^{137}$ Cs is influenced primarily by the weighted time spent in the receptor environments, which depends on the population proportions and time spent in the receptor environments by the population groups. A very small fraction of the BDCF variance for ${ }^{137} \mathrm{Cs}$ is due to the parameters related to the ingestion pathways. Although consumption of crops is an unimportant pathway for ${ }^{137} \mathrm{Cs}$, soil-to-depth transfer factors, soil depth, and the partition coefficient were correlated with the BDCF component for ingestion, inhalation of radon decay products, and external exposure. This is because the variation in those input parameters is large relative to variation in the input parameters used to calculate external exposure.

The correlation coefficients for both inhalation components for all radionuclides are presented in Table 6.3-3. Only those correlations that are non-zero at the 99 percent confidence interval (absolute value of the correlation coefficient equal or greater than 0.0812) are shown in the table, plus the next correlation that is below this threshold. Table 6.3-3 includes "false" correlations (marked with an "a”) that were above the threshold value, as explained in Section 6.2.3.2. The correlation coefficients are the same for all radionuclides because the stochastic parameters that are used to calculate these BDCF components are radionuclide-independent.

Table 6.3-3. Correlation Coefficients for the Input Parameters and Inhalation Components of Biosphere Dose Conversion Factors for the Volcanic Ash Exposure Scenario

\begin{tabular}{|c|c|c|c|c|c|}
\hline \multicolumn{3}{|c|}{ Short-term Inhalation Component } & \multicolumn{3}{|c|}{ Long-term Inhalation Component } \\
\hline Parameter & CC & $\mathrm{CC}^{2}$ & Parameter & CC & $\mathrm{CC}^{2}$ \\
\hline $\begin{array}{l}\text { Ash mass loading, active } \\
\text { outdoors environment }\end{array}$ & 0.641 & 0.411 & $\begin{array}{l}\text { Dust mass loading, active } \\
\text { outdoors }\end{array}$ & 0.555 & 0.308 \\
\hline $\begin{array}{l}\text { Enhancement factor, active } \\
\text { outdoors environment }\end{array}$ & 0.494 & 0.244 & Critical thickness & -0.496 & 0.246 \\
\hline Critical thickness & -0.447 & 0.200 & $\begin{array}{l}\text { Enhancement factor, active } \\
\text { outdoors }\end{array}$ & 0.491 & 0.241 \\
\hline $\begin{array}{l}\text { Population proportion, outdoor } \\
\text { workers }\end{array}$ & 0.251 & 0.063 & $\begin{array}{l}\text { Population proportion, outdoor } \\
\text { workers }\end{array}$ & 0.294 & 0.087 \\
\hline $\begin{array}{l}\text { Time spent active outdoors, } \\
\text { non-workers }\end{array}$ & 0.154 & 0.024 & $\begin{array}{l}\text { Time spent active outdoors, } \\
\text { non-workers }\end{array}$ & 0.176 & 0.031 \\
\hline $\begin{array}{l}\text { Time spent active outdoors, } \\
\text { indoor workers }\end{array}$ & 0.138 & 0.019 & $\begin{array}{l}\text { Time spent active outdoors, } \\
\text { indoor workers }\end{array}$ & 0.146 & 0.021 \\
\hline $\begin{array}{l}\text { Lead transfer factor for leafy } \\
\text { vegetables }\end{array}$ & 0.093 & 0.009 & $\begin{array}{l}\text { Thorium transfer factor for } \\
\text { leafy vegetables a }\end{array}$ & -0.096 & 0.009 \\
\hline $\begin{array}{l}\text { Time spent in inactive outdoors } \\
\text { environment, outdoor workers }\end{array}$ & -0.092 & 0.009 & $\begin{array}{l}\text { Chlorine transfer factor for } \\
\text { leafy vegetables }\end{array}$ & 0.089 & 0.008 \\
\hline$\prod_{a}^{T}$ in transfer coefficient for meat & -0.088 & 0.008 & $\begin{array}{l}\text { Chlorine transfer factor for } \\
\text { fruits }^{\text {a }}\end{array}$ & 0.084 & 0.007 \\
\hline $\begin{array}{l}\text { Enhancement factor, active } \\
\text { indoor environment }\end{array}$ & 0.083 & 0.007 & $\begin{array}{l}\text { Protactinium transfer factor for } \\
\text { other vegetables }^{\text {a }}\end{array}$ & 0.078 & 0.006 \\
\hline $\begin{array}{l}\text { Neptunium transfer factor for } \\
\text { forage }^{\text {a }}\end{array}$ & 0.081 & 0.007 & & & \\
\hline $\begin{array}{l}\text { Dry biomass for other } \\
\text { vegetables }\end{array}$ & 0.080 & 0.006 & & & \\
\hline
\end{tabular}

Source: Excel file VA Correlations.xIs (Appendix A).

${ }^{a}$ false correlation; $\mathrm{CC}=$ correlation coefficient 
For both inhalation components, air mass loading for the active outdoors environment and the enhancement factor for the same environment are among the input parameters with large contributions to the BDCF variance. Critical thickness is also important, as it controls the level of activity concentration in the resuspendable layer of surface soil that, in turn, influences inhalation dose. These three parameters account for a significant fraction of the BDCF variance. Population proportion of outdoor workers is a less important contributor to the BDCF variance (Table 6.3-3).

\subsubsection{Analysis of the Environmental Transport Pathways and Radionuclide Accumulation in the Environmental Media}

The dose to the receptor from deposition of contaminated volcanic ash on the soil surface arises from the intake of and exposure to contaminated soil and other environmental media that become contaminated as a result of environmental transport of radionuclides from the soil. The environmental media included in the biosphere model for the volcanic ash exposure scenario include surface soil, air, plants, and animals. For the volcanic ash exposure scenario, water is assumed uncontaminated. Surface soil becomes contaminated from the deposition of volcanic ash. Airborne contamination is a result of resuspension of contaminated soil. Radionuclide accumulation in plants occurs as a result of transport from soil and air. Feed and soil are sources of radionuclide intake by animals.

This section discusses calculation of radionuclide concentrations in the environmental media.

\subsubsection{Radionuclide Accumulation in Surface Soil}

In the volcanic exposure scenario, surface soil is a primary source of contamination for all environmental transport and receptor exposure pathways. These pathways include resuspension of soil particles, with the subsequent deposition on crops and inhalation by humans; external exposure; radionuclide uptake by crops through their roots; emission of radon and inhalation of radon decay products by humans; and soil ingestion by humans and animals.

The biosphere model for the volcanic ash exposure scenario calculates radionuclide concentrations in the resuspendable layer of uncultivated surface soil and radionuclide concentrations in the surface soil down to the tilling depth for a unit activity deposited per unit surface area of cultivated soil. Unlike the biosphere model for the groundwater scenario, the biosphere model for the volcanic ash scenario does not account for any subsequent addition or removal of radionuclides. This function is carried out in the TSPA model.

To calculate radionuclide concentrations in the cultivated surface soil, the available activity of a radionuclide is mixed within the tilling depth of the soil, thus making the radionuclide concentrations inversely proportional to the soil depth. This relationship results in a relatively strong negative correlation of the ingestion pathway of the ingestion-radon-external exposure BDCF component with the soil depth, as shown in Table 6.3-2. The radionuclide concentration in the resuspendable layer of uncultivated soil is likewise dependent on the critical thickness, which results in a negative correlation of the inhalation BDCF components with the critical thickness. 
The dependence of the short-term inhalation BDCF for ${ }^{241} \mathrm{Am}$ on the value of the critical thickness is shown in Figure 6.3-6. The relationship between these two variables for other radionuclides is the same.

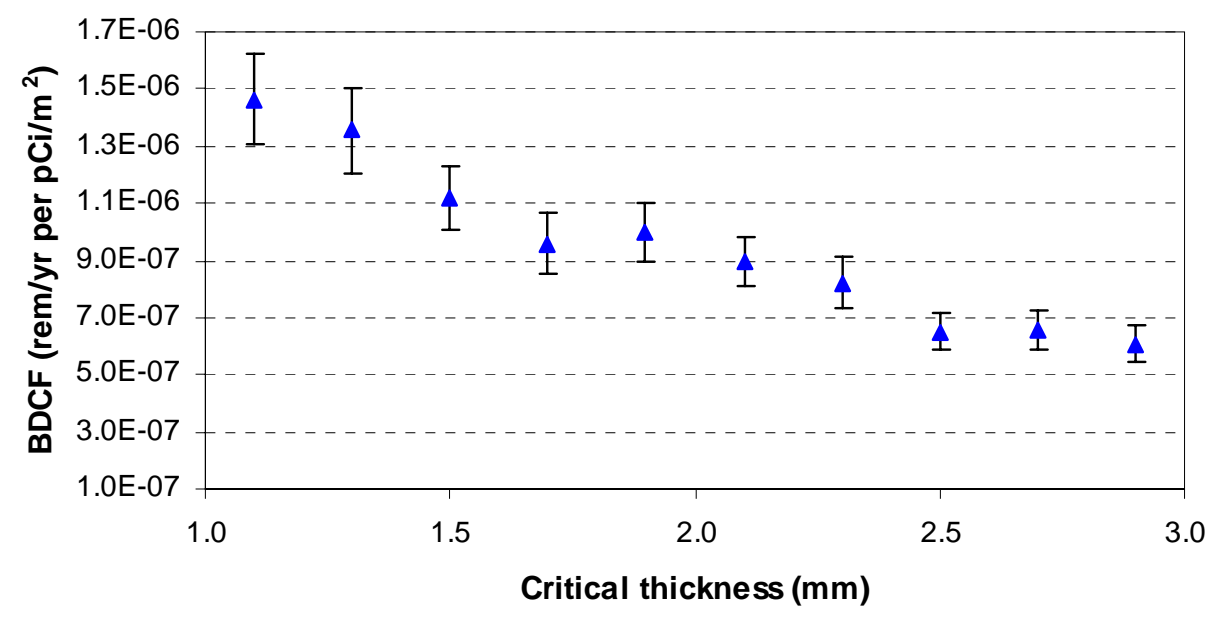

Source: Excel file Dependence of VA BDCFs on Inputs.xls (Appendix A).

Figure 6.3-6. Dependence of Short-Term Inhalation BDCF Component for ${ }^{241}$ Am on Critical Thickness

\subsubsection{Radionuclide Transport to Air}

Radionuclide transport from soil to air occurs via resuspension of surface soil and exhalation of radon from the soil. Resuspension of soil results in particulate matter becoming airborne.

The radionuclide concentration in air is calculated in the biosphere model for the volcanic ash exposure scenario using the same method as that used in the groundwater exposure scenario, as the product of radionuclide concentration in soil, atmospheric mass loading, and the enhancement factor (see Section 6.2.4.2.2). The average concentrations of ${ }^{241} \mathrm{Am}$ in air in the four contaminated environments used in the calculation of the short-term and long-term inhalation BDCF components are shown in Figure 6.3-7. The graph shows that the level of radionuclide concentration in air for the active outdoor environment is much higher than that in any of the remaining environments.

The radionuclide concentration in the active outdoors environment is high because both atmospheric mass loading and the enhancement factor are high for this environment, as shown in Figures 6.3-8 and 6.3-9, respectively. The mass loading for ash shown in Figure 6.3-8 is used to calculate the increase in mass loading following an eruption for the short-term inhalation BDCF component. The nominal mass loading is used in the calculation of the long-term inhalation BDCF component. 


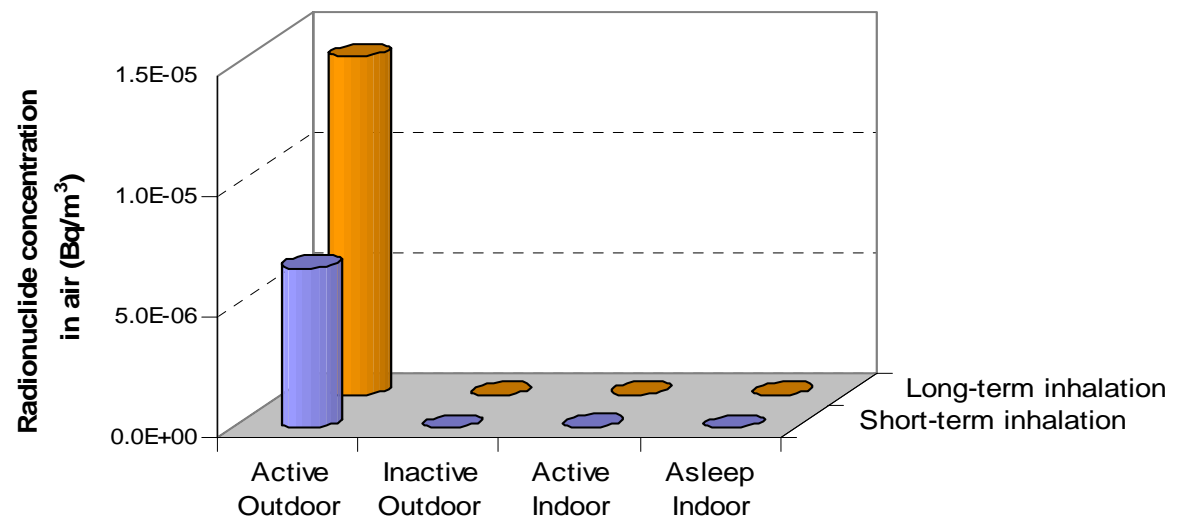

Source: Excel file Detailed Pathway Analysis VA.xIs (Appendix A).

Figure 6.3-7. Average Radionuclide Concentration in Air by Receptor Environment Used in Calculation of Short-Term and Long-Term Inhalation BDCF Component.

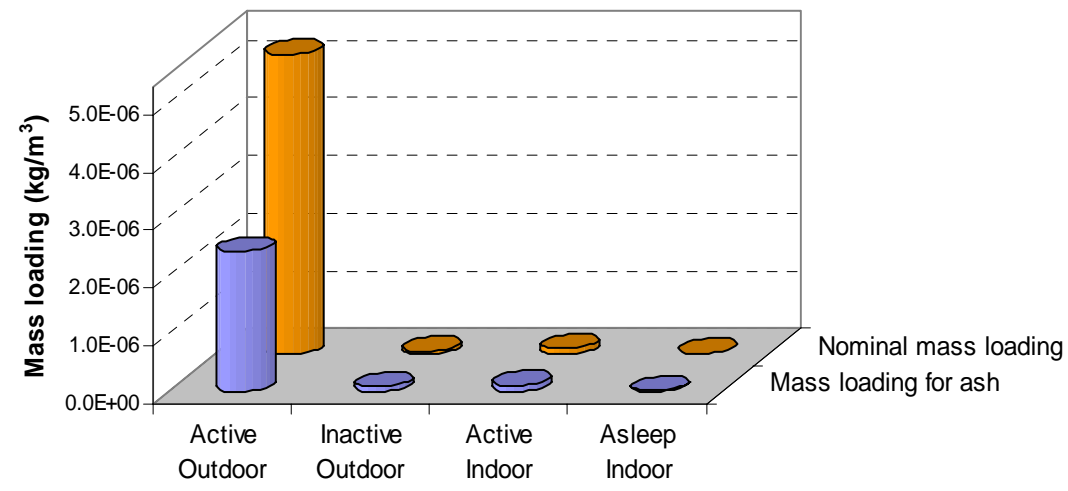

Source: Excel file Detailed Pathway Analysis VA.xls (Appendix A).

Figure 6.3-8. Average Atmospheric Mass Loading by Receptor Environment Used in Calculation of Short-Term (Mass Loading for Ash) and Long-Term (Nominal Mass Loading) Inhalation BDCF Component

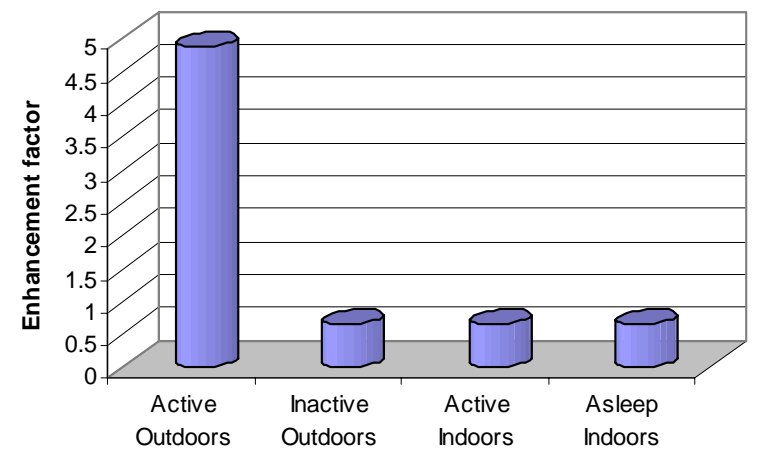

Source: Excel file Detailed Pathway Analysis VA.xIs (Appendix A).

Figure 6.3-9. Average Enhancement Factor by Receptor Environment Used in Calculation of the Short-Term and Long-Term Inhalation BDCF Component 
A dependence of both inhalation BDCF components for ${ }^{241} \mathrm{Am}$ on mass loading in the active outdoors environment is shown in Figures 6.3-10 and 6.3-11 for the averaged values of the variables. The graphs show that the inhalation BDCF components are strongly affected by mass loading in the active outdoors environment. This parameter accounts for 41 and 31 percent of the variance in the short-term and long-term inhalation BDCF component, respectively (Table 6.3-3).

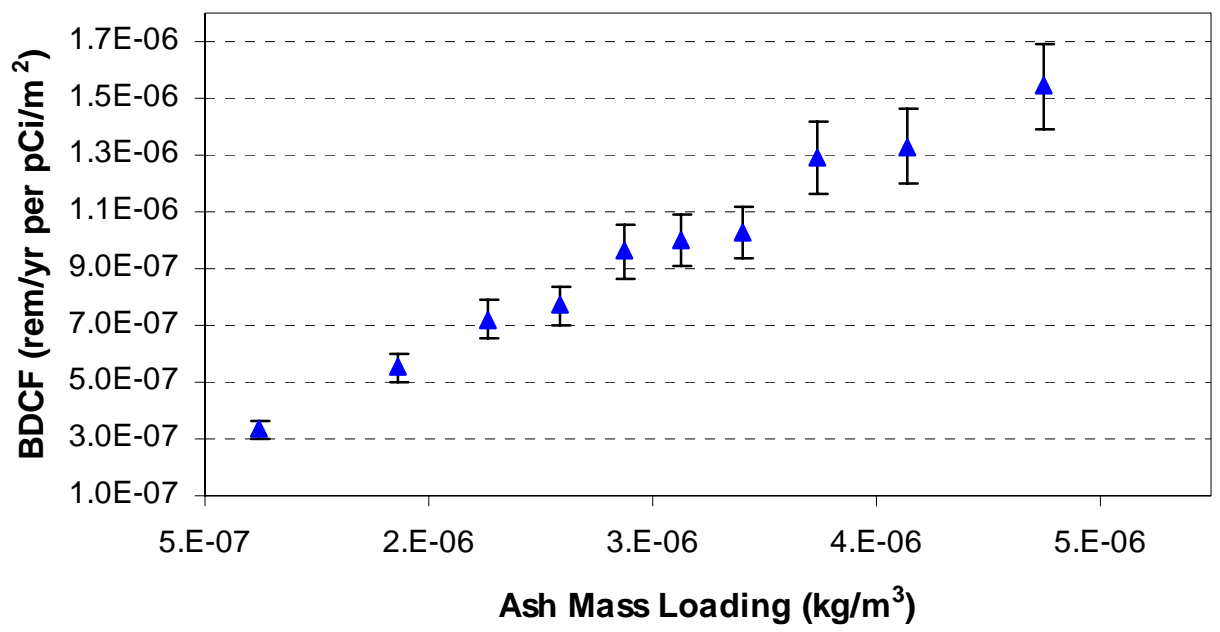

Source: Excel file Dependence of VA BDCFs on Inputs.xIs (Appendix A).

Figure 6.3-10. Dependence of Short-Term Inhalation BDCF Component for ${ }^{241} \mathrm{Am}$ on Ash Mass Loading in the Active Outdoors Environment

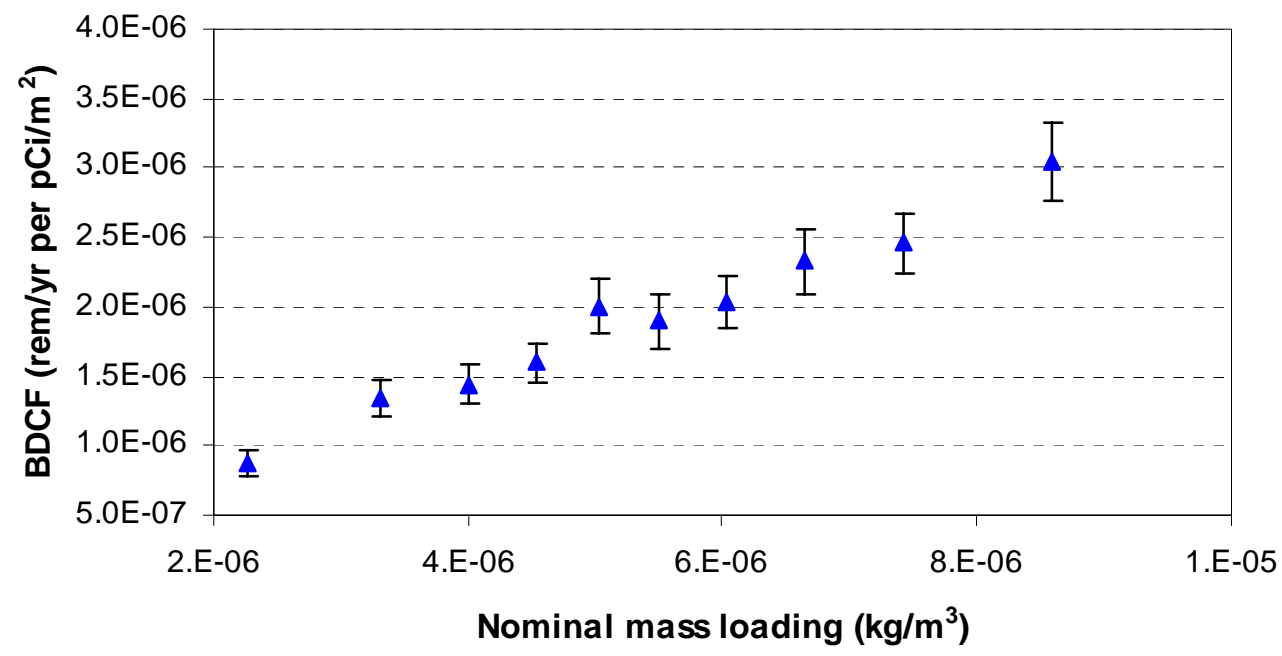

Source: Excel file Dependence of VA BDCFs on Inputs.xIs (Appendix A).

Figure 6.3-11. Dependence of Long-Term Inhalation BDCF Component for ${ }^{241} \mathrm{Am}$ on Nominal Mass Loading in the Active Outdoors Environment 
The influence of mass loading on the inhalation BDCF components for ${ }^{241}$ Am was investigated in a series of deterministic model runs. Table 6.3-4 shows the values of mass loading in the active outdoors environment used in the runs and the corresponding values of the short-term and long-term inhalation BDCF components and the percent change relative to the average value.

Table 6.3-4. Inhalation BDCF Components for ${ }^{241} \mathrm{Am}$ and Percent Change for Different Levels of Mass Loading in the Active Outdoors Environment

\begin{tabular}{|c|c|c|c|c|c|c|}
\hline \multirow[b]{2}{*}{$\begin{array}{c}\text { Mass Loading } \\
\text { Conditions }\end{array}$} & \multicolumn{3}{|c|}{ Short-term Inhalation } & \multicolumn{3}{|c|}{ Long-term Inhalation } \\
\hline & $\begin{array}{c}\text { Ash mass } \\
\text { loading, } \mathrm{mg} / \mathrm{m}^{3}\end{array}$ & $\begin{array}{c}\text { BDCF, rem/yr } \\
\text { per pCi/m }\end{array}$ & $\begin{array}{c}\% \text { BDCF } \\
\text { change }\end{array}$ & $\begin{array}{l}\text { Nominal mass } \\
\text { loading, } \mathrm{mg} / \mathrm{m}^{3}\end{array}$ & $\begin{array}{c}\text { BDCF, rem/yr } \\
\text { per pCi/m }\end{array}$ & $\begin{array}{c}\% \text { BDCF } \\
\text { change }\end{array}$ \\
\hline Average & 2.5 & 7.14E-07 & & 5.0 & 1.35E-06 & \\
\hline Maximum & 5.0 & 1.35E-06 & 89.0 & 10.0 & 2.62E-06 & 94.3 \\
\hline Double Maximum & 10.0 & 2.62E-06 & 267.2 & 20.0 & 5.16E-06 & 282.8 \\
\hline
\end{tabular}

NOTE: BDCFs were calculated in deterministic runs of ERMYN_VA_MC8_Det_Base.gsm by changing the radionuclide selection and the values of mass loading. The percent change for the BDCFs was calculated in the Excel spreadsheet Dependence of VA BDCFs on Inputs.xIs (Appendix A).

The value of the inhalation BDCF components changes practically in proportion to the value of ash mass loading and nominal mass loading in the outdoor active environment. The other environments have a negligible influence on the inhalation BDCF component, as demonstrated in Table 6.3-5, which shows the results of the deterministic model runs for different values of mass loading in the inactive outdoors environment.

Table 6.3-5. Inhalation BDCF Components for ${ }^{241} \mathrm{Am}$ and Percent Change for Different Levels of Mass Loading in the Inactive Outdoors Environment

\begin{tabular}{|c|c|c|c|c|c|c|}
\hline \multirow[b]{2}{*}{$\begin{array}{l}\text { Mass Loading } \\
\text { Conditions }\end{array}$} & \multicolumn{3}{|c|}{ Short-term Inhalation } & \multicolumn{3}{|c|}{ Long-term Inhalation } \\
\hline & $\begin{array}{c}\text { Ash mass } \\
\text { loading, } \mathrm{mg} / \mathrm{m}^{3}\end{array}$ & $\begin{array}{c}\text { BDCF, rem/yr } \\
\text { per pCi/m² }\end{array}$ & $\begin{array}{c}\% \text { BDCF } \\
\text { change }\end{array}$ & $\begin{array}{l}\text { Nominal mass } \\
\text { loading, } \mathrm{mg} / \mathrm{m}^{3}\end{array}$ & $\begin{array}{c}\text { BDCF, rem/yr } \\
\text { per pCi/m² }\end{array}$ & $\begin{array}{c}\% \text { BDCF } \\
\text { change }\end{array}$ \\
\hline Average & 0.06 & 7.14E-07 & & 0.06 & $1.35 \mathrm{E}-06$ & \\
\hline Maximum & 0.20 & 7.27E-07 & 1.9 & 0.10 & 1.35E-06 & 0.3 \\
\hline Double Maximum & 0.40 & 7.47E-07 & 4.7 & 0.20 & $1.36 \mathrm{E}-06$ & 1.0 \\
\hline
\end{tabular}

NOTE: $\quad$ BDCFs were calculated in deterministic runs of ERMYN_VA_MC8_Det_Base.gsm by changing the radionuclide selection and the values of mass loading. The percent change for the BDCFs was calculated in the Excel spreadsheet Dependence of VA BDCFs on Inputs.xIs (Appendix A).

Even when mass loading in the inactive outdoor environment is twice the maximum value used in the model, the BDCF change is less than 5 percent.

\subsubsection{Radionuclide Transport to Crops}

Environmental transport pathways considered in the biosphere model for the volcanic ash exposure scenario that result in radionuclide transport to crops are:

- Deposition of resuspended contaminated soil in crop surfaces

- Root uptakes of radionuclides present in surface soil. 
The fractions of radionuclide concentration in the crop types considered in the biosphere model for ${ }^{90} \mathrm{Sr}$, ${ }^{99} \mathrm{Tc}$, and ${ }^{241} \mathrm{Am}$ are summarized in Table 6.3-6; see Excel file Detailed Pathway Analysis VA.xls in Appendix A for calculation details. Radionuclides ${ }^{90} \mathrm{Sr}$ and ${ }^{99} \mathrm{Tc}$ were selected to show pathway contributions leading to contamination of crops for radionuclides whose BDCF contributions arise primarily from ingestion of locally produced food, including crops. Americium-241 is a radionuclide that was identified as an important expected dose contributor in the previous assessment. However, for this radionuclide, the ingestion pathway contribution is negligible; inhalation of particulate matter is the only important BDCF contributor (see Table 6.3-1).

Table 6.3-6. Fractions of Activity in Crops from Environmental Transport Processes for the Volcanic Ash Exposure Scenario

\begin{tabular}{|l|l|l|c|c|c|c|}
\hline \multirow{2}{*}{ Radionuclide } & \multicolumn{4}{|c|}{ Crop Type } \\
\cline { 3 - 8 } & Transport Process & $\begin{array}{c}\text { Leafy } \\
\text { Vegetables }\end{array}$ & $\begin{array}{c}\text { Other } \\
\text { Vegetables }\end{array}$ & Fruits & Grains & $\begin{array}{c}\text { Cattle } \\
\text { Forage }\end{array}$ \\
\hline \multirow{2}{*}{ Strontium-90 } & Dust deposition & 0.025 & 0.008 & 0.027 & 0.028 & 0.017 \\
\cline { 2 - 7 } & Root uptake & 0.975 & 0.992 & 0.973 & 0.972 & 0.983 \\
\hline \multirow{2}{*}{ Technetium-99 } & Dust deposition & 0.001 & 0.002 & 0.005 & 0.008 & 0.002 \\
\cline { 2 - 8 } & Root uptake & 0.999 & 0.998 & 0.995 & 0.992 & 0.998 \\
\hline \multirow{2}{*}{ Americium-241 } & Dust deposition & 0.758 & 0.624 & 0.636 & 0.810 & 0.628 \\
\cline { 2 - 8 } & Root uptake & 0.242 & 0.376 & 0.364 & 0.190 & 0.372 \\
\hline
\end{tabular}

Source: Excel file Detailed Pathway Analysis VA.xIs (Appendix A).

For ${ }^{90} \mathrm{Sr}$ and ${ }^{99} \mathrm{Tc}$, root uptake is a dominant mechanism of radionuclide transport to crops. Deposition of resuspended soil contributes only up to 3 percent of the activity concentration in plants. Americium-241 is an element that is taken up by plant roots relatively poorly, so its concentration in plants is much less than that for ${ }^{90} \mathrm{Sr}$ and ${ }^{99} \mathrm{Tc}$ (concentrations from dust deposition are the same for all radionuclides because the parameters used to model these pathways are not element- or radionuclide-dependent). Therefore, deposition of resuspended soil in plant surfaces is the dominant mechanism of ${ }^{241} \mathrm{Am}$ transport to plants.

\subsubsection{Radionuclide Transport to Animal Products}

Environmental transport pathways considered in the biosphere model for the volcanic ash exposure scenario that result in radionuclide transport to animal products are animal consumption of feed and animal consumption of surface soil as well as, indirectly, environmental transport pathways leading to radionuclide accumulation in forage plants and in the surface soil.

The fractions of radionuclide concentration in animal products resulting from feed and soil consumption are summarized in Table 6.3-7. 
Table 6.3-7. Fractions of Activity in Animal Products from Environmental Transport Processes for the Volcanic Ash Exposure Scenario

\begin{tabular}{|c|l|c|c|c|c|}
\hline \multirow{2}{*}{ Radionuclide } & & \multicolumn{4}{|c|}{ Animal Product } \\
\cline { 3 - 6 } & Transport Process & Meat & Milk & Poultry & Eggs \\
\hline \multirow{2}{*}{ Strontium-90 } & Feed Consumption & 0.959 & 0.958 & 0.653 & 0.651 \\
\cline { 2 - 6 } & Soil Consumption & 0.041 & 0.042 & 0.347 & 0.349 \\
\hline \multirow{2}{*}{ Technetium-99 } & Feed Consumption & 0.996 & 0.996 & 0.901 & 0.900 \\
\cline { 2 - 6 } & Soil Consumption & 0.004 & 0.004 & 0.099 & 0.100 \\
\hline \multirow{2}{*}{ Americium-241 } & Feed Consumption & 0.262 & 0.249 & 0.050 & 0.050 \\
\cline { 2 - 6 } & Soil Consumption & 0.738 & 0.751 & 0.950 & 0.950 \\
\hline
\end{tabular}

Source: Excel file Detailed Pathway Analysis VA.xIs (Appendix A).

For ${ }^{90} \mathrm{Sr}$ and ${ }^{99} \mathrm{Tc}$, feed consumption is the dominant mechanism of radionuclide transport to animal products, contributing 96 to nearly 100 percent of radionuclide concentration in meat and milk and 65 to 90 percent for poultry and eggs.

The environmental pathway contributions for ${ }^{241} \mathrm{Am}$ differ markedly from those for ${ }^{90} \mathrm{Sr}$. This is because americium is poorly taken up from the soil by cattle forage, so its overall activity concentration in forage is less than that for ${ }^{90} \mathrm{Sr}$. Thus, soil consumption becomes more important, in relative terms, because the activity intake for soil ingestion by an animal is the same for all radionuclides.

\subsubsection{Receptor Exposure Pathways}

\subsubsection{Inhalation Pathway}

The inhalation dose for the volcanic ash exposure scenario is calculated in the biosphere model using a time-budget method, analogous to that used in the biosphere model for the groundwater exposure scenario (Section 6.2.5.2.1). Inhalation of particulate matter arising from resuspension of contaminated soil occurs in all receptor environments except away from contaminated area. Figure 6.3-12 illustrates the fractional contributions from these environments to the BDCF component that results from inhalation of airborne particulates. The Excel file Detailed Pathway Analysis VA.xls is the source of this and other figures in this section.

The inhalation dose accrued in an active outdoors environment is a dominant contributor to both inhalation BDCF components. Inhalation intake for an environment depends on the time spent in this environment by the receptor, the activity concentration in the air, and the receptor breathing rate. The activity concentration in air is an environment-specific quantity that depends on the level of soil-disturbing and dust-generating activities that are conducted in an environment and on the increase in mass activity concentration of resuspended material relative to the mass activity concentration of the surface soil. This parameter was discussed in Section 6.3.4.2. The activity concentration in air is highest in the active outdoors environment for nominal conditions (used for calculation of the long-term inhalation BDCF component) and the post volcanic conditions of increased dustiness in air (used for calculation of the short-term BDCF component) as shown in Figure 6.3-7. 


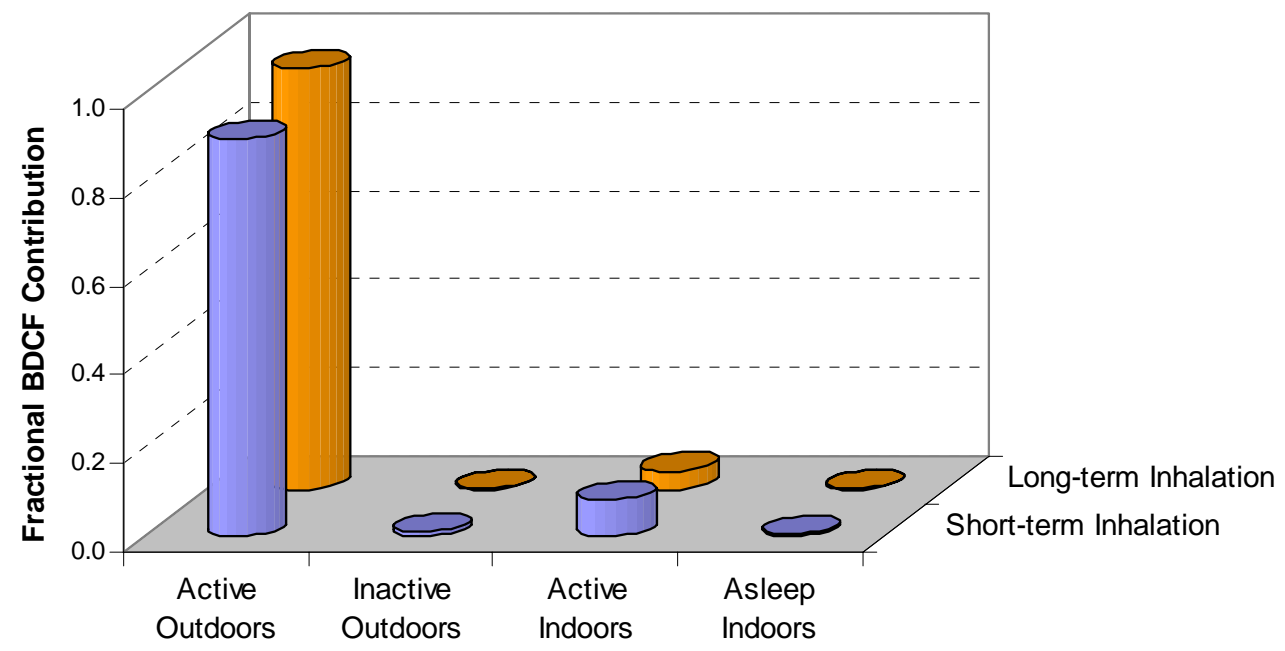

Source: Excel file Detailed Pathway Analysis VA.xls (Appendix A).

Figure 6.3-12. Fractional Contributions of the Receptor Environments to the Short-Term and Long-Term BDCF Components

Inhalation exposure for an environment also depends on the time spent in this environment by the receptor (see Section 6.2.5.2.1 for additional discussion). Figure 6.3-13 shows the weighted time for all receptor environments. There are small differences between this figure and Figure 6.2-29. The differences result from the larger aerial extent of the contaminated area for the volcanic ash scenario, compared with the groundwater scenario, which places some work locations inside the contaminated area for the volcanic ash scenario and outside for the groundwater scenario. Still, the conclusions drawn in Section 6.2.5.2.1 remain valid; the receptor spends relatively few hours per day in the active outdoors environment and most of his time indoors.

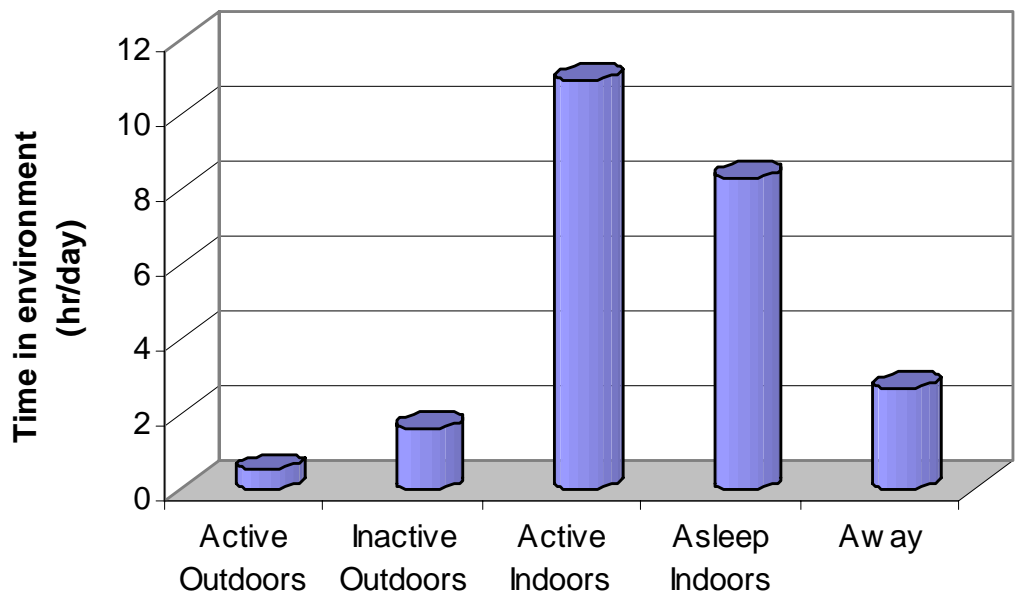

Source: Excel file Detailed Pathway Analysis VA.xIs (Appendix A).

Figure 6.3-13. Weighted Time Spent in the Receptor Environments for Volcanic Ash Exposure Scenario 
Another factor affecting radionuclide intake by inhalation is the breathing rate. The breathing rate in the biosphere model is environment-dependent and is the highest in the active outdoor environment. Breathing rates for various environments were shown in Figure 6.2-30. The same breathing rates were used for both exposure scenarios.

The correlation statistics presented in Table 6.3-3 indicate that there are only a few receptor-related parameters used in the calculation of the inhalation BDCF components that affect their variance. These parameters are the proportion of outdoor workers and the times spent by non-workers and indoor workers (the largest population fractions) in the active outdoors environment. Time spent in the inactive outdoor environment by outdoor workers is another receptor-related parameter listed in Table 6.3-3 as having a small, but statistically significant correlation with the short-term inhalation BDCF component.

Because the majority of the inhalation exposure occurs in the active outdoor environment, which is associated with the highest levels of airborne particulate matter, the modeling results for the inhalation pathway are sensitive to the proportion of outdoor workers, who spend about half of their time outdoors in the active outdoors environment, and on the time spent in this environment by the other population groups. The dependence of the short-term inhalation component on the fraction of outdoor workers is shown in Figure 6.3-14; there is a direct correlation between these two variables.

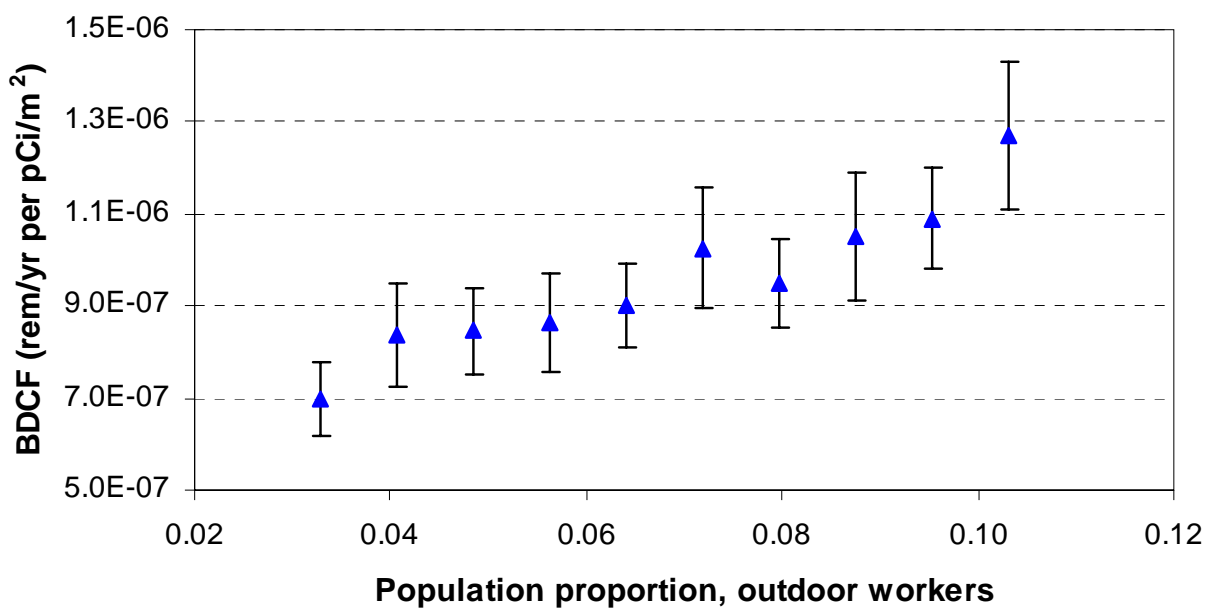

Source: Excel file Dependence of VA BDCFs on Inputs.xIs (Appendix A).

Figure 6.3-14. Dependence of Short-Term Inhalation BDCF Component for ${ }^{241} \mathrm{Am}$ on Proportion of Outdoor Workers

To investigate the influence of the time spent in the active outdoors environment by the outdoor workers, the biosphere model was run in the deterministic mode for average conditions, that is, 50 percent of the outdoor workers' work time spent in the active outdoors environment, and for 75 percent of their work time spent in the active outdoors environment. The parameter values and the model results are summarized in Table 6.3-8. 
Table 6.3-8. Effect of a Change in the Daily Exposure Time in the Active Outdoor Environment for Outdoor Workers on the Long-Term Inhalation BDCF Component for ${ }^{241} \mathrm{Am}$

\begin{tabular}{|c|c|c|c|c|c|c|c|}
\hline \multirow[b]{2}{*}{ Conditions } & \multicolumn{5}{|c|}{ Time in Environment, hr/day } & \multirow{2}{*}{$\begin{array}{l}\text { BDCF, } \\
\text { rem/yr per } \\
\mathrm{pCi} / \mathrm{m}^{2}\end{array}$} & \multirow[b]{2}{*}{$\begin{array}{l}\% \text { BDCF } \\
\text { change }\end{array}$} \\
\hline & $\begin{array}{c}\text { Active } \\
\text { Outdoors }\end{array}$ & $\begin{array}{l}\text { Inactive } \\
\text { Outdoors }\end{array}$ & $\begin{array}{c}\text { Active } \\
\text { Indoors }\end{array}$ & Asleep & Away & & \\
\hline $\begin{array}{l}\text { Average ( } 50 \% \text { time in active } \\
\text { outdoors environment) }\end{array}$ & 3.1 & 4.2 & 6.4 & 8.3 & 2.0 & $1.350 \mathrm{E}-06$ & \\
\hline $\begin{array}{l}75 \% \text { time in active outdoors } \\
\text { environment }\end{array}$ & 4.5 & 2.8 & 6.4 & 8.3 & 2.0 & $1.565 \mathrm{E}-06$ & 16.0 \\
\hline
\end{tabular}

NOTE: BDCFs were calculated in deterministic runs of ERMYN_VA_MC8_Det_Base.gsm by changing the radionuclide selection and the exposure time in the active outdoors environment. The percent change for the BDCFs was calculated in the Excel spreadsheet Dependence of VA BDCFs on Inputs.xIs (Appendix A).

If the time in the active outdoors environment is increased from 50 to 75 percent of the work time (an increase of about 1.4 hours in a total of 5.5 hours per day worked), the long-term BDCF component increases by about 16 percent.

The members of all population groups that constitute the RMEI spend some time away from the contaminated area. Outdoor workers, indoor workers, and non-workers spend on average 2 hours per day away; commuters spend, on average, 8 hours per day away, including their work time. To evaluate the sensitivity of the inhalation BDCF component to the time away, 2 hours of away time were subtracted for each of the population groups. This time was proportionally added to the times spent in other environments except for time asleep, which was kept fixed at 8.3 hours per day. The resulting times are shown in Table 6.3-9.

Table 6.3-9. Base Case and Modified Times Spent in Receptor Environments by Population Groups

\begin{tabular}{|l|c|c|c|c|c|c|c|c|}
\hline \multirow{2}{*}{ Environment } & \multicolumn{2}{|c|}{ Commuters } & \multicolumn{2}{c|}{ Non-workers } & \multicolumn{2}{c|}{ Outdoor workers } & \multicolumn{2}{c|}{ Indoor workers } \\
\cline { 2 - 10 } & Base Case & Modified & Base Case & Modified & Base Case & Modified & Base Case & Modified \\
\hline Active outdoors & 0.3 & 0.4 & 0.3 & 0.3 & 3.1 & 3.6 & 0.3 & 0.3 \\
\hline Inactive outdoors & 2.0 & 2.5 & 1.2 & 1.4 & 4.2 & 4.8 & 1.5 & 1.7 \\
\hline Active indoors & 5.1 & 6.5 & 12.2 & 14.0 & 6.4 & 7.3 & 11.9 & 13.7 \\
\hline Asleep & 8.3 & 8.3 & 8.3 & 8.3 & 8.3 & 8.3 & 8.3 & 8.3 \\
\hline Away & 8.3 & 6.3 & 2.0 & 0 & 2.0 & 0 & 2.0 & 0 \\
\hline
\end{tabular}

Source: Excel file Dependence of VA BDCFs on Inputs.xls (Appendix A).

The long-term inhalation BDCF component for ${ }^{241} \mathrm{Am}$ increased from $1.350 \times 10^{-6} \mathrm{rem} / \mathrm{yr}$ per $\mathrm{pCi} / \mathrm{m}^{2}$ to $1.473 \times 10^{-6} \mathrm{rem} / \mathrm{yr}$ per $\mathrm{pCi} / \mathrm{m}^{2}$, that is, by 9 percent.

\subsubsection{Ingestion}

The ingestion dose is expected to be an insignificant contributor to the receptor exposure from a volcanic eruption, because most of the expected dose likely will be due to inhalation of transuranics. There are only a few radionuclides, such as ${ }^{90} \mathrm{Sr}$ and ${ }^{99} \mathrm{Tc}$, with a considerable fraction of the dose that is due to the consumption of contaminated food (Table 6.3-1). The dose from consumption of a given food type is calculated in the biosphere model as the product of radionuclide concentration in the food products, consumption rate, and the dose coefficient 
converting radionuclide intake by ingestion to dose. The consumption rates of locally produced food were discussed in Section 6.2.5.1.

\subsubsection{External Exposure}

Only a few radionuclides have a large fraction of the dose attributable to the external exposure pathway. The most important of these radionuclides is ${ }^{137} \mathrm{Cs}$, with over 98 percent of the BDCF contribution attributable to external exposure (Table 6.3-1). External exposure depends on the level of contamination in the soil and the amount of time the receptor is exposed to radionuclides in the soil. The biosphere model assumes that, for calculating external exposure, radionuclides are always at the soil surface, that is, that there is no attenuation of external radiation in the soil. The only attenuation considered in the model is the shielding provided by dwellings.

The exposure time in the model is population-weighted (see Section 6.2.5.2.1). Therefore, population proportions and time spent in the receptor environments are parameters that influence the variance in the BDCF contribution from external exposure (Table 6.3-2). 


\section{INTENTIONALLY LEFT BLANK}




\section{CONCLUSIONS}

\subsection{SUMMARY OF FINDINGS}

This section provides a summary of the analysis findings. The following conclusions are applicable to the model files and input parameters described in Section 4.1 and may not apply for other model files or parameters. There is no output DTN generated in this analysis.

\subsubsection{Groundwater Exposure Scenario}

This section summarizes the findings of the importance and sensitivity analyses for the groundwater exposure scenario for the radionuclides used throughout Section 6.2.

\section{Carbon-14}

The exposure to ${ }^{14} \mathrm{C}$ arises from ingestion of locally produced food and water. Variation in the BDCF for ${ }^{14} \mathrm{C}$ is almost entirely due to uncertainty in ingestion of food. The inhalation and external exposure pathways are negligible. Ingestion of water contributes an average of 18 percent. The relative importance of individual food consumption pathways reflects roughly the annual consumption rates of these foods. The notable exception is fish consumption. Although consumption rate of locally produced fish is relatively low, the fish consumption pathway is a dominant pathway, contributing on average up to 49 percent of the $\mathrm{BDCF}$ for ${ }^{14} \mathrm{C}$, because of the high calculated concentration of ${ }^{14} \mathrm{C}$ in fish.

Carbon has a high bioaccumulation in fish. This is because carbon is a major element that constitutes about 24 percent of the animal soft tissue (see Table 4.1-1 for values for meat and poultry). The bioaccumulation factor is a ratio of activity concentration (of ${ }^{14} \mathrm{C}$, in this scenario) in water to that in fish. The value of the bioaccumulation factor for the biosphere model was developed based on a literature review. Published values for the bioaccumulation factor for freshwater fish were measured in natural systems where the system components are in equilibrium. In other words, all components affecting the fish (water, aquatic plants, and aquatic organisms at a lower trophic level) are in equilibrium with the water with regard to the concentration of the contaminants. This is not the case for farm-grown fish, because they are raised using commercial feed, which is not contaminated. Because most of the carbon in fish comes from their food, the concentration of ${ }^{14} \mathrm{C}$ in fish is overestimated. In the absence of bioaccumulation factors for farmed fish, it is difficult to evaluate the degree of conservatism associated with the estimates of ${ }^{14} \mathrm{C}$ concentration in fish.

\section{Technetium-99}

The average BDCF for ${ }^{99} \mathrm{Tc}$ is the lowest of all radionuclides considered in the biosphere model. About one-half of the BDCF for ${ }^{99} \mathrm{Tc}$ is from consumption of water. The remainder is attributable to the consumption of locally produced food. Contributions from inhalation and external exposure are 2 to 3 orders of magnitude less than that for ingestion. The variation in the BDCF for ${ }^{99} \mathrm{Tc}$ is almost entirely due to variation in radionuclide concentrations in foods that are ingested. 
The BDCF contributions from individual food consumption pathways generally reflect the consumption rates for locally produced food types. Although locally produced food consumption rates have a direct influence on the magnitude and thus importance of the individual ingestion pathways, they have little influence the BDCF variance. This is because the consumption rates for the RMEI were developed as the means for the Amargosa Valley population, and their distributions reflect the uncertainty about the mean, rather than the population variability. Doubling the consumption rates used in the model increased the BDCF for ${ }^{99}$ Tc by about 22 percent.

The model input parameters with the greatest degree of variance in common with the BDCF for ${ }^{99} \mathrm{Tc}$ are the overwatering rate, soil-to-plant transfer factors, transfer coefficients for animal products, and $\mathrm{K}_{\mathrm{d}}$. The overwatering rate, and to a lesser degree the technetium partition coefficient, control the removal of ${ }^{99}$ Tc from surface soil. The transfer factors and transfer coefficients for various food types and animal products influence the level of bioaccumulation of ${ }^{99} \mathrm{Tc}$ in these media. The values of these parameters used as biosphere model inputs typically span several orders of magnitude. However, orders of magnitude changes in the value of the partition coefficient result in the ${ }^{99}$ Tc BDCF changing by a factor of two or less.

Regarding the environmental transport pathways leading to the contamination of crops with ${ }^{99} \mathrm{Tc}$, root uptake dominates the transport to crops, contributing about two-thirds of radionuclide concentration, with water deposition contributing about one-third. Feed consumption is the most important environmental transport pathway for animal products.

\section{Iodine-129}

Pathway contributions to the BDCF for ${ }^{129}$ I are similar to those for ${ }^{99} \mathrm{Tc}$, with consumption of water and ingestion of locally produced food accounting for the majority of the BDCF. Likewise, variation in the BDCF for ${ }^{129}$ I arises from variation in the food ingestion component. Contributions from the inhalation and external exposure components are 2 orders of magnitude less than that for ingestion and do not influence the variability in the value of the BDCF for ${ }^{129}$ I. The contribution from drinking water is greater than that for ${ }^{99} \mathrm{Tc}$, accounting, on average, for 69 percent of the average BDCF. Consumption of animal products (meat, milk and eggs) is more important than consumption of crops. Contributions from consumption of meat and milk are more important for ${ }^{129}$ I than those for ${ }^{99} \mathrm{Tc}$ because of the greater values of transfer coefficients for iodine than for technetium.

The distribution of the BDCF for ${ }^{129} \mathrm{I}$ is relatively narrow due to a large contribution from drinking water, which is a fixed BDCF component.

The input parameters that contribute the most to the BDCF variance for ${ }^{129}$ I are those that control radionuclide removal from the surface soil (such as $K_{d}$ and overwatering rate), and thus the level of radionuclide concentration in the surface soil. Also important are those parameter that quantify radionuclide transport to crops and animal products. The contributions of environmental pathways to ${ }^{129}$ I concentration in crops are different from those for ${ }^{99} \mathrm{Tc}$. Deposition of irrigation water is the most important plant pathway. Contamination of animal products is primarily due to feed consumption. 
Estimates of the BDCF for ${ }^{129}$ I calculated using the biosphere model are conservative because the model does not account for the stable isotope of iodine, ${ }^{127} \mathrm{I}$, which is ubiquitous in the environment (NCRP 1983 [DIRS 167511], p. 2) and which will affect the dose from ${ }^{129}$ I. Another factor that limits the amount of ${ }^{129} \mathrm{I}$ that can be accumulated in the human body, and specifically in the thyroid where iodine accumulates, is the low specific activity of ${ }^{129}$ I (NCRP 1983 [DIRS 167511], p. 1). Human intake of iodine involves both isotopes, and the thyroid content of these isotopes reflects the relative abundance of ${ }^{127} \mathrm{I}$ and ${ }^{129} \mathrm{I}$ taken into the body.

\section{Uranium-233}

On average, around 70 percent of the dose from ${ }^{233} \mathrm{U}$ is due to inhalation of particulate matter, regardless of the climate. Consumption of drinking water and inhalation of aerosols generated by evaporative coolers are next, but neither one of these pathways contributes, on average, more than 21 percent. The importance of inhalation of aerosols from operation of evaporative coolers decreases for the future climate to, on average, less than 6 percent of the BDCF for ${ }^{233} \mathrm{U}$. The variance for the ${ }^{233} \mathrm{U}$ BDCF is caused primarily by the $K_{d}$, which for uranium has an exceptionally large range, spanning 6 orders of magnitude from the $1^{\text {st }}$ to $99^{\text {th }}$ percentile. Although ${ }^{233} \mathrm{U}$ has a very small ingestion component, variation in the BDCF for this radionuclide is influenced by parameters related to that component. This is due to a high degree of correlation between the $K_{d} S$ and the transfer factors used in the biosphere model. Similarly to other actinides, the BDCF for ${ }^{233} \mathrm{U}$ also depends on the parameters that influence the level of equilibrium activity concentration of this radionuclide in surface soil, such as the erosion rate and the overwatering rate.

Receptor exposure to ${ }^{233} \mathrm{U}$ in resuspended particulate matter occurs primarily in the active outdoors environment. Thus, those model input parameters that are used to calculate doses from this pathway in this environment influence the BDCF value. These parameters are the mass loading and enhancement factor for the active outdoors environment.

\section{Neptunium-237}

Water consumption accounts, on average, for nearly half of the average BDCF value for ${ }^{237} \mathrm{~Np}$ for the present-day climate and for almost 64 percent for the future climate. Inhalation is the second most important exposure pathway. On average, about 60 percent of the inhalation dose for the present-day climate is from inhalation of resuspended soil, with the reminder due to inhalation of aerosols produced by evaporative coolers. The contribution of the inhalation pathway decreases for the future climate because of the lower level of radionuclide concentrations in the soil (due to a lower irrigation rate) and the decreased use of evaporative coolers in the future. The average contribution of the inhalation of aerosols generated in evaporative coolers is, on average, less than 5 percent in the future climate. Calculation of BDCF contribution from this pathway involves an uncertain parameter that quantifies the fraction of radionuclides transferred from water used in a cooler to the indoor air. The value of this parameter was not found in the literature; however the model results are relatively insensitive to its value. 
Inhalation of particulate matter from resuspended soil depends on the level of mass loading in the receptor environments. Of particular importance is the active outdoors environment. Doubling the mass loading in this environment from an average value of $5 \mathrm{mg} / \mathrm{m}^{3}$ results in about a 14 percent increase in the present-day climate BDCF for ${ }^{237} \mathrm{~Np}$. Mass loading in the other environments does not contribute substantially to the BDCF.

\section{Plutonium-239}

For ${ }^{239} \mathrm{Pu}$, inhalation of particulate matter is the most important pathway, accounting for about one-half of the BDCF. Consumption of water is the second most important pathway contributing on average from 28 percent (present-day climate) to about 44 percent (future climate) to the BDCF for ${ }^{239} \mathrm{Pu}$. Consumption of locally produced food and external exposure are not important.

The variance in the BDCF for ${ }^{239} \mathrm{Pu}$ arises almost exclusively from uncertainty in the inhalation pathway, since the water ingestion pathway contribution to the BDCF is fixed. The contributions to inhalation exposure from inhalation of particulate matter (resuspended contaminated soil) and inhalation of aerosols generated by evaporative coolers are, on average, 53 percent and 9 percent, respectively, for the present-day climate, and 44 and 3 percent, respectively, for the future climate.

The dose accrual from inhalation of particulate matter occurs primarily in the active outdoors environment, where the concentration of ${ }^{239} \mathrm{Pu}$ in air is the highest of all receptor environments. Increasing mass loading in this environment from an average value of $5 \mathrm{mg} / \mathrm{m}^{3}$ to $10 \mathrm{mg} / \mathrm{m}^{3}$ increases the BDCF for ${ }^{239} \mathrm{Pu}$ by almost 50 percent. The other environments have a negligible contribution to the BDCF for ${ }^{239} \mathrm{Pu}$. The BDCF contribution from inhalation of particulate matter also depends on the time spent by the receptor in the active outdoors environment.

\subsubsection{Volcanic Ash Exposure Scenario}

The pathway contributions for the volcanic ash scenario are modeled as functions of ash thickness and time since the eruption. Inhalation of particulate matter is the most important BDCF contributor for most radionuclides that were identified as important in the previous TSPA. These radionuclides were primarily transuranics.

For both inhalation components, air mass loading for the active outdoors environment and the enhancement factor for the same environment are among the input parameters with large contributions to the BDCF value and variance. Critical thickness is also important as it controls the level of activity concentration in the resuspendable layer of surface soil that, in turn, influences inhalation dose. If the value of mass loading in this environment is doubled, keeping all other parameters at the same value, the inhalation BDCF components also double.

External exposure is a dominant pathway for ${ }^{137} \mathrm{Cs}$, which may be important within a few tens to a few hundreds of years postclosure. The biosphere model assumes that, for calculating external exposure, radionuclides are always at the soil surface, that is, there is no attenuation of external radiation in the soil and the receptor is always exposed to contaminated soil while in contaminated areas. The only attenuation considered in the model is the shielding provided by dwellings. This approach overestimates the receptor's exposure from radionuclides that are external to the receptor's body. 


\subsection{HOW THE ACCEPTANCE CRITERIA WERE ADDRESSED}

The following information describes how this analysis addresses the acceptance criteria in the YMRP (NRC 2003 [DIRS 163274], Sections 2.2.1.3.13, 2.2.1.3.14 and 2.2.1.4.1). Only those acceptance criteria that are applicable to this report are discussed (see Section 4.2). In most cases, the applicable acceptance criteria are not addressed solely by this report; rather, the acceptance criteria are fully addressed when this report is considered in conjunction with other analysis and model reports that describe the biosphere. Where a subcriterion includes several components, only some of those components may be addressed. How these components are addressed is summarized below.

\section{Acceptance Criteria from Section 2.2.1.3.13, Redistribution of Radionuclides in Soil}

\section{Acceptance Criterion 1, System Description and Model Integration Are Adequate.}

Subcriterion (1): The BDCFs are used directly by the TSPA. The analyses in Sections 6.2 and 6.3, which identify the important soil-related pathways, processes, and parameters for the groundwater and volcanic exposure scenarios, respectively, show that the TSPA adequately incorporates important site features, physical phenomena, and couplings.

Subcriterion (2): This analysis of the BDCFs, which constitute the biosphere model abstraction, provides the technical bases for determining the relative importance of the transport processes for the following processes related to the redistribution of radionuclides in soil that are important to repository performance: radionuclide accumulation in surface soil (Section 6.2.4.1); resuspension of surface soil (Section 6.2.4.2.2.). This analysis also provides technical bases for determining the relative importance of the receptor exposure pathways from groundwater that are important to repository development and are related to redistribution of radionuclides in soil: ingestion (Section 6.2.5.1), inhalation of particulate matter (Section 6.2.5.2.1), and external exposure (Section 6.2.5.3).

Similarly, the following volcanic ash exposure scenario processes related to redistribution of radionuclides in soil that are important to repository development are addressed: radionuclide accumulation in surface soil (Section 6.3.4.1) and radionuclide transport to air (Section 6.3.4.2). This analysis also provides technical bases for determining the relative importance of the receptor exposure pathways related to volcanic exposure that are related to redistribution of radionuclides in soil and are important to repository development: inhalation (Section 6.3.5.1), ingestion (Section 6.3.5.2), and internal exposure (Section 6.3.5.3).

Subcriterion (3): Section 6.1 shows that this importance and sensitivity analysis is consistent with modeling of redistribution of radionuclide in soil (climate, soil, sorption coefficients, volcanic ash properties, and radionuclide properties) used in other abstractions. For example, the analysis demonstrates that the uncertainty in partition coefficients does not have a proportional impact on BDCFs. Input parameters and assumptions for the biosphere model were developed in a series of five analysis reports (BSC 2004 [DIRS 169673]; BSC 2004 [DIRS 169671]; BSC 2004 [DIRS 169672]; BSC 2004 [DIRS 169458]; and BSC 2004 [DIRS 169459]) that are used consistently over all applicable abstractions. 


\section{Acceptance Criterion 2, Data Are Sufficient for Model Justification.}

Subcriterion (1): Input parameters for the biosphere model were developed and justified in a series of five analysis reports: BSC 2004 [DIRS 169673], BSC 2004 [DIRS 169671], BSC 2004 [DIRS 169672], BSC 2004 [DIRS 169458], and BSC 2004 [DIRS 169459]. These parameters are consistent with the characteristics of the reference biosphere, including the processes of radionuclide redistribution in soil and with the definition of the RMEI in 10 CFR 63.312 [DIRS 156605].

Subcriterion (2): Data are sufficient, as provided in Sections 4.1, 6.2, and 6.3 and in the five analysis reports on which this report is based, to assess the adequacy of characterization and incorporation of biosphere FEPs related to radionuclide redistribution in soil in the abstraction. The sensitivity analyses provided by this report show that adequate data were available and that new data would not invalidate prior modeling results or affect the extent to which the performance of the system is affected by a parameter value.

\section{Acceptance Criterion 3, Data Uncertainty Is Characterized and Propagated Through the Model Abstraction.}

Subcriterion (1): This sensitivity analysis shows that the values of parameters related to redistribution of radionuclide in soil, their assumed ranges, probability distributions, and bounding assumptions used in the TSPA are technically defensible, reasonably account for uncertainties and variabilities and do not result in an under-representation of the risk estimate. For example, Section 6.2.4.1 shows that the BDCFs are relatively insensitive to order-of-magnitude changes in $\mathrm{K}_{\mathrm{d}}$, thereby adding confidence to the selection of these values for the biosphere model.

Subcriterion (2): The reports documenting development of the model parameter values (BSC 2004 [DIRS 169673], BSC 2004 [DIRS 169671], BSC 2004 [DIRS 169672], BSC 2004 [DIRS 169458], and BSC 2004 [DIRS 169459]) and sensitivity analyses provided by this report show that the technical bases for the values and ranges of the BDCFs used in the abstraction, including soil characteristics, crop types, and irrigation rates, are appropriate. Data on the airborne particulate concentrations, which are based on the resuspension of appropriate material in a climate and level of disturbance similar to that which is expected to be found at the location of the reasonably maximally exposed individual during the compliance time period, are adequately selected and justified.

Subcriterion (3): The uncertainty analyses show that data uncertainty in the values of parameters related to radionuclide redistribution in soil is adequately represented in the BDCFs developed for the TSPA. Statistics are developed for correlations between parameters comprising the BDCFs and radionuclides important to the groundwater exposure scenario (Section 6.2.4) and for radionuclides important to the volcanic ash exposure scenario (Section 6.3.4).

Subcriterion (4): The objective of this analysis was to identify parameters or processes that most influence the results of biosphere model. This subcriterion is addressed throughout this analysis report. 


\section{Acceptance Criteria from Section 2.2.1.3.14, Biosphere Characteristics}

\section{Acceptance Criterion 1, System Description and Model Integration Are Adequate.}

Subcriterion (1): The BDCFs are used directly by the TSPA. The analyses in Sections 6.2 and 6.3, which identify the important pathways, processes, and parameters for the groundwater and volcanic exposure scenarios, respectively, show that the TSPA adequately incorporates important site features, physical phenomena, and couplings.

Subcriterion (2): This analysis of the BDCFs, which constitutes the biosphere model abstraction, provides the technical bases for determining the relative importance of the transport processes for the following groundwater-related biosphere characteristics that are important to repository performance: radionuclide accumulation in surface soil (Section 6.2.4.1); operation of evaporative coolers (Section 6.2.4.2.1); resuspension of surface soil (Section 6.2.4.2.2.); radionuclide transport to crops (Section 6.2.4.3); radionuclide transport to animal products (Section 6.2.4.4); and radionuclide transport to aquatic foods (Section 6.2.4.5). This analysis also provides technical bases for determining the relative importance of the receptor exposure pathways from groundwater that are important to repository development: ingestion (Section 6.2.5.1), inhalation of particulate matter (Section 6.2.5.2.1), inhalation of aerosols generated by evaporative coolers (Section 6.2.5.2.2), and external exposure (Section 6.2.5.3).

Similarly, the following volcanic-exposure-related biosphere characteristics that are important to repository development are addressed: radionuclide accumulation in surface soil (Section 6.3.4.1), radionuclide transport to air (Section 6.4.3.2), radionuclide transport to crops (Section 6.3.4.3), and radionuclide transport to animal products (Section 6.3.4.4). This analysis also provides technical bases for determining the relative importance of the receptor exposure pathways related to volcanic exposure that are important to repository development: inhalation (Section 6.3.5.1), ingestion (Section 6.3.5.2), and internal exposure (Section 6.3.5.3).

Subcriterion (3): Section 6.1 shows that this importance and sensitivity analysis is consistent with modeling of biosphere characteristics (climate, soil, sorption coefficients, volcanic ash properties, and radionuclide properties) used in other abstractions. Input parameters and related assumptions for the biosphere model were developed in a series of five analysis reports (BSC 2004 [DIRS 169673], BSC 2004 [DIRS 169671], BSC 2004 [DIRS 169672], BSC 2004 [DIRS 169458], and BSC 2004 [DIRS 169459]) that are used consistently over all applicable abstractions.

\section{Acceptance Criterion 2, Data Are Sufficient for Model Justification.}

Subcriterion (1): Input parameters for the biosphere model were developed and justified in a series of five analysis reports: BSC 2004 [DIRS 169673], BSC 2004 [DIRS 169671], BSC 2004 [DIRS 169672], BSC 2004 [DIRS 169458], and BSC 2004 [DIRS 169459]. These parameters are consistent with the characteristics of the reference biosphere and the definition of the RMEI in 10 CFR 63.312 [DIRS 156605]. The dietary and lifestyle characteristics of the RMEI were determined based on surveys of people living in the Amargosa Valley. Adequate descriptions of how the data were used, interpreted, and appropriately synthesized into the parameters are provided in the five analysis reports noted above. 
Subcriterion (2): Data are sufficient, as provided in Sections 4.1, 6.2, and 6.3 and in the analysis reports on which this report is based, to assess the adequacy of characterization and incorporation of biosphere-related FEPs (such as climate changes) in the abstraction. The sensitivity analyses provided by this report show that adequate data were available and that new data would not invalidate prior modeling results or affect the extent to which the performance of the system is affected by a parameter value.

\section{Acceptance Criterion 3, Data Uncertainty Is Characterized and Propagated Through the Model Abstraction.}

Subcriterion (1): This sensitivity analysis shows that the parameter values, assumed ranges, probability distributions, and bounding assumptions used in the TSPA are technically defensible, reasonably account for uncertainties and variabilities and do not result in an under-representation of the risk estimate. For example, Section 6.2.4.1 shows that the BDCFs are relatively insensitive to order-of-magnitude changes in $\mathrm{K}_{\mathrm{d}}$, thereby adding confidence to the selection of these values for the biosphere model. The RMEI, per the requirements of 10 CFR 63.312(b) [DIRS 156605], reflects the dietary and lifestyle characteristics of people living in the Amargosa Valley (Section 6.1.3) and the parameters and data are consistent with that information.

Subcriterion (2): The reports documenting development of the model parameter values (BSC 2004 [DIRS 169673], BSC 2004 [DIRS 169671], BSC 2004 [DIRS 169672], BSC 2004 [DIRS 169458], and BSC 2004 [DIRS 169459]) and sensitivity analyses provided by this report show that the technical bases for the values and ranges of the BDCFs used in the abstraction, including consumption rates, plant and animal uptake factors, mass-loading factors, and biosphere dose conversion factors, are consistent with site characterization data, and are technically defensible and adequate.

Subcriterion (4): The uncertainty analyses show that uncertainty is adequately represented in the BDCFs developed for the biosphere characteristics modeling in the TSPA.

Subcriterion (6): Section 6.2.2 evaluates the exposure pathway contributions to the BDCFs and identifies those pathways that contribute significantly to the BDCFs so as to most influence repository performance for the time period of compliance specified in 10 CFR Part 63. Section 6.2.5 discusses the important pathways, processes, and parameters for selected radionuclides.

Acceptance Criteria from Section 2.2.1.4.1, Demonstration of Compliance with the Postclosure Public Health and Environmental Standards

Acceptance Criterion 2, An Adequate Demonstration Is Provided That the Annual Dose to the Reasonably Maximally Exposed Individual in Any Year During the Compliance Period Does Not Exceed the Exposure Standard

Subcriterion (1): Sections 6.1.5, 6.2.1, and 6.2.3 explain that the BDCFs for each scenario class, groundwater and volcanic ash exposures, are based on 1,000 model realizations.

Subcriterion (2): Section 6.2.1 describes the calculations of the BDCFs, which are used to calculate the annual dose curves, and Figure 6.2-1 displays the results for BDCFs for the 
present-day climate scenario in ranges which include their mean and median values, minima and maxima, and the $5^{\text {th }}$ and $95^{\text {th }}$ percentile confidence intervals to represent uncertainty in the dose calculations. 


\section{INTENTIONALLY LEFT BLANK}




\section{INPUTS AND REFERENCES}

\subsection{DOCUMENTS CITED}

BSC (Bechtel SAIC Company) 2003. Total System Performance

166296 Assessment-License Application Methods and Approach. TDR-WIS-PA-000006 REV 00 ICN 01. Las Vegas, Nevada: Bechtel SAIC Company. ACC: DOC.20031215.0001.

BSC 2004. Agricultural and Environmental Input Parameters for the Biosphere 169673 Model. ANL-MGR-MD-000006, Rev. 02. Las Vegas, Nevada: Bechtel SAIC Company.

BSC 2004. Biosphere Model Report. MDL-MGR-MD-000001, Rev. 01. Las Vegas, Nevada: Bechtel SAIC Company.

BSC 2004. Characteristics of the Receptor for the Biosphere Model. ANL-MGRMD-000005 REV 03. Las Vegas, Nevada: Bechtel SAIC Company.

ACC: DOC.20040913.0004.

BSC 2004. Disruptive Event Biosphere Dose Conversion Factor Analysis.

ANL-MGR-MD-000003 REV 03. Las Vegas, Nevada: Bechtel SAIC Company. ACC: DOC.20040908.0007.

BSC 2004. Environmental Transport Input Parameters for the Biosphere Model. ANL-MGR-MD-000007 REV 02. Las Vegas, Nevada: Bechtel SAIC Company. ACC: DOC.20040913.0003.

BSC 2004. Future Climate Analysis. ANL-NBS-GS-000008 REV 01. Las Vegas, Nevada: Bechtel SAIC Company. ACC: DOC.20040908.0005.

BSC 2004. Inhalation Exposure Input Parameters for the Biosphere Model. ANL- 169458 MGR-MD-000001 REV 03. Las Vegas, Nevada: Bechtel SAIC Company.

ACC: DOC.20040913.0001.

BSC 2004. Nominal Performance Biosphere Dose Conversion Factor Analysis. ANL-MGR-MD-000009, Rev. 03. Las Vegas, Nevada: Bechtel SAIC Company. ACC: DOC.20040909.0003.

BSC 2004. Q-List. 000-30R-MGR0-00500-000-000 REV 00. Las Vegas, Nevada: 168361 Bechtel SAIC Company. ACC: ENG.20040721.0007.

BSC 2004. Soil-Related Input Parameters for the Biosphere Model. ANL-NBS-MD- 169459 000009, Rev. 02. Las Vegas, Nevada: Bechtel SAIC Company.

ACC: DOC.20040913.0002. 
BSC 2004. Technical Work Plan for Biosphere Modeling and Expert Support.

TWP-NBS-MD-000004 REV 03. Las Vegas, Nevada: Bechtel SAIC Company.

ACC: DOC.20040527.0004.

Canori, G.F. and Leitner, M.M. 2003. Project Requirements Document.

166275

TER-MGR-MD-000001 REV 02. Las Vegas, Nevada: Bechtel SAIC Company.

ACC: DOC.20031222.0006.

CRWMS (Civilian Radioactive Waste Management System) M\&O (Management

153246

and Operating Contractor) 2000. Total System Performance Assessment for the Site

Recommendation. TDR-WIS-PA-000001 REV 00 ICN 01. Las Vegas, Nevada:

CRWMS M\&O. ACC: MOL.20001220.0045.

CRWMS M\&O 2001. Identification of the Critical Group (Consumption of Locally

Produced Food and Tap Water). ANL-MGR-MD-000005 REV 01 ICN 00.

Las Vegas, Nevada: CRWMS M\&O. ACC: MOL.20010119.0109.

CRWMS M\&O 2001. Nominal Performance Biosphere Dose Conversion Factor

Analysis. ANL-MGR-MD-000009 REV 01. Las Vegas, Nevada: CRWMS M\&O.

ACC: MOL.20010123.0123.

GoldSim Technology Group. 2003. User's Guide, GoldSim Probabilistic Simulation

166226

Environment. Version 8.01. Redmond, Washington: Golder Associates.

TIC: 255170.

ICRP (International Commission on Radiological Protection) 1994. Human

Respiratory Tract Model for Radiological Protection. Volume 24, Nos. 1-3 of

Annals of the ICRP. Smith, H., ed. ICRP Publication 66. New York, New York:

Pergamon. TIC: 249223.

NCRP (National Council on Radiation Protection and Measurements) 1983.

167511

Iodine-129: Evaluation of Releases from Nuclear Power Generation. NCRP Report

No. 75. Bethesda, Maryland: National Council on Radiation Protection and

Measurements. TIC: 241527.

NRC (U.S. Nuclear Regulatory Commission) 2003. Yucca Mountain Review Plan,

Final Report. NUREG-1804, Rev. 2. Washington, D.C.: U.S. Nuclear Regulatory

Commission, Office of Nuclear Material Safety and Safeguards. TIC: 254568.

Steel, R.G.D. and Torrie, J.H. 1980. Principles and Procedures of Statistics: A

153705

Biometrical Approach. 2nd Edition. New York, New York: McGraw Hill. TIC: 6322

\subsection{CODES, STANDARDS, REGULATIONS, AND PROCEDURES}

10 CFR 63. Energy: Disposal of High-Level Radioactive Wastes in a Geologic

156605

Repository at Yucca Mountain, Nevada. Readily available. 
AP-2.22Q, Rev. 1, ICN 1. Classification Analyses and Maintenance of the Q-List. Washington, D.C.: U.S. Department of Energy, Office of Civilian Radioactive Waste Management.

AP-2.27Q, Rev. 1, ICN 4. Planning for Science Activities. Washington, D.C.:

U.S. Department of Energy, Office of Civilian Radioactive Waste Management.

AP-SIII.9Q Rev. 1, ICN 7. Scientific Analyses. Washington, D.C.: U.S. Department of Energy, Office of Civilian Radioactive Waste Management.

LP-SI.11Q-BSC, Rev. 0, ICN 1. Software Management. Washington, D.C.: U.S.

Department of Energy, Office of Civilian Radioactive Waste Management.

\subsection{SOURCE DATA, LISTED BY DATA TRACKING NUMBER}

MO0307SEPFEPS4.000. LA FEP List. Submittal date: 07/31/2003.

MO0403SPAAEIBM.002. Agricultural and Environmental Input Parameters for the

169392 Biosphere Model. Submittal date: 03/22/2004.

MO0406SPAETPBM.002. Environmental Transport Input Parameters for the 170150 Biosphere Model. Submittal date: 06/24/2004.

MO0407MWDGSBMF.000. GoldSim Biosphere Model Files Used to Generate 170852 Biosphere Dose Conversion Factors for the Groundwater Exposure Scenario. Submittal date: 07/22/2004.

MO0407MWDGSMFV.000. GoldSim Biosphere Model Files Used to Generate Biosphere Dose Conversion Factors for the Volcanic Ash Exposure Scenario. Submittal date: 07/22/2004.

MO0407SEPFEPLA.000. LA FEP List. Submittal date: 07/20/2004.

MO0407SPACRBSM.002. Characteristics of the Receptor for the Biosphere Model. Submittal date: 07/19/2004.

MO0407SPAINEXI.002. Inhalation Exposure Input Parameters for the Biosphere 170597 Model. Submittal date: 07/12/2004.

MO0407SPASRPBM.002. Soil Related Parameters for the Biosphere Model. 170755 Submittal date: 07/20/2004.

\subsection{SOFTWARE CODES}

BSC 2004. Software Code: GoldSim. V8.01 Service Pack 4. PC, Windows 2000. 169695 10344-8.01SP4-00. 
INTENTIONALLY LEFT BLANK 
Biosphere Dose Conversion Factor Importance and Sensitivity Analysis 


\section{A. LIST AND DESCRIPTION OF FILES GENERATED IN THIS ANALYSIS}

This appendix contains the list and description of the files generated in this analysis and included in the Appendix A compact disk.

The GoldSim files were taken from DTN: MO0407MWDGSBMF.000 [DIRS 170852] and DTN: MO0407MWDGSMFV.000 [DIRS 170856]. Because the DTNs include many GoldSim files, only those that were used in this analysis are included in Appendix A, as shown in Figure A-1. A designator_SA was added to the file name for tracking purposes.

\begin{tabular}{|c|c|c|c|c|}
\hline \multirow{5}{*}{$\begin{array}{l}\text { Stochastic GoldSim } \\
\text { Files }\end{array}$} & Name $A$ & Size & Type & Modified \\
\hline & BERMYN_GW_FC8_I129_SA.gsm & $11,502 \mathrm{~KB}$ & GoldSim Model & $7 / 31 / 20042: 58 \mathrm{PM}$ \\
\hline & (3)ERMYN_GW_FC8_Np237D_SA.gsm & $11,502 \mathrm{~KB}$ & GoldSim Model & 7/31/2004 3:15 PM \\
\hline & BERMYN_GW_FC8_Pu239_SA.gsm & $11,508 \mathrm{~KB}$ & GoldSim Model & $8 / 1 / 20047: 25 \mathrm{PM}$ \\
\hline & BERMYN_GW_FC8_Tc99_SA.gsm & $11,512 \mathrm{~KB}$ & GoldSim Model & $8 / 3 / 20045: 19 \mathrm{PM}$ \\
\hline \multirow{3}{*}{ \pm This folder is Online. } & [8ERMYN_GW_FC8_U233_SA.gsm & $11,502 \mathrm{~KB}$ & GoldSim Model & 7/31/2004 3:07 PM \\
\hline & 38ERMYN_GW_MC8_C14_SA.gsm & $11,599 \mathrm{~KB}$ & GoldSim Model & $8 / 1 / 20045: 49 \mathrm{PM}$ \\
\hline & 38ERMYN_GW_MC8_I129_SA.gsm & $11,600 \mathrm{~KB}$ & GoldSim Model & $8 / 1 / 20045: 28 \mathrm{PM}$ \\
\hline Select an item to view its description. & BERMYN_GW_MC8_Np237D_SA.gsm & $11,613 \mathrm{~KB}$ & GoldSim Model & $8 / 2 / 20043: 56 \mathrm{PM}$ \\
\hline See also: & BERMYN_GW_MC8_PU239_SA.gsm & $11,623 \mathrm{~KB}$ & GoldSim Model & $8 / 4 / 20048: 17$ AM \\
\hline My Documents & BERMYN_GW_MC8_Tc99_SA.gsm & $11,622 \mathrm{~KB}$ & GoldSim Model & $8 / 1 / 20041: 47 \mathrm{PM}$ \\
\hline My Network Places & (8)ERMYN_GW_MC8_U233_SA.gsm & $11,613 \mathrm{~KB}$ & GoldSim Model & $8 / 1 / 20045: 36 \mathrm{PM}$ \\
\hline \multirow[t]{4}{*}{ My Computer } & 3 ERMYN_VA_MC8_Am241_SA.gsm & $8,217 \mathrm{~KB}$ & GoldSim Model & $8 / 6 / 20045: 37 \mathrm{PM}$ \\
\hline & 8ERMYN_VA_MC8_Cs137D_SA.gsm & $8,126 \mathrm{~KB}$ & GoldSim Model & $8 / 5 / 20049: 27 \mathrm{AM}$ \\
\hline & 28ERMYN_VA_MC8_Sr90D_SA.gsm & $8,392 \mathrm{~KB}$ & GoldSim Model & $8 / 6 / 20047: 57 \mathrm{AM}$ \\
\hline & 18]ERMYN_VA_MC8_TC99_SA.gsm & $8,392 \mathrm{~KB}$ & GoldSim Model & $8 / 6 / 20047: 59$ AM \\
\hline
\end{tabular}

Figure A-1. GoldSim Files for Stochastic Runs of the Biosphere Model for the Groundwater and Volcanic Ash Exposure Scenarios

Two GoldSim files taken from DTN: MO0407MWDGSBMF.000 [DIRS 170852] and DTN: MO0407MWDGSMFV.000 [DIRS 170856] were modified to perform deterministic runs of the biosphere model. These files, ERMYN_GW_MC8_Det_Base.gsm, and ERMYN_VA_MC8_Det_Base.gsm, constituted the base files that were used to run the model deterministically, using input parameter values listed in Tables 4.1-1 to 4.1-4. The deterministic results for the cases described in this analysis were manually copied from the screen. Figure A-2 shows the details for the base files.

\begin{tabular}{|c|c|c|c|c|}
\hline 7 แ 7 & Name $\triangle$ & Size & Type & Modified \\
\hline $4=$ & BERMYN_GW_MC8_Det_Base.gsm & $3,518 \mathrm{~KB}$ & GoldSim Model & 9/9/2004 9:47 AM \\
\hline $\begin{array}{l}\text { Deterministic } \\
\text { GoldSim Files }\end{array}$ & BERMYN_VA_MC8_Det_Base.gsm & $2,336 \mathrm{~KB}$ & GoldSim Model & 7/27/2004 9:23 AM \\
\hline
\end{tabular}

Figure A-2. GoldSim Files for Deterministic Runs of the Biosphere Model for the Groundwater and Volcanic Ash Exposure Scenarios 
Figure A-3 shows the list of the Excel files supporting this analysis. The files were used to carry out calculations and to produce graphs presented in this report.

\begin{tabular}{|c|c|c|c|c|}
\hline \multirow{4}{*}{7} & Name $\Lambda$ & Size & Type & Modified \\
\hline & Dependence of GW BDCFs on Inputs.xls & $4,419 \mathrm{~KB}$ & Microsoft Excel Worksheet & $10 / 12 / 200410: 51 \mathrm{AM}$ \\
\hline & DDDependence of VA BDCFs on Inputs.xls & $626 \mathrm{~KB}$ & Microsoft Excel Worksheet & $9 / 27 / 20048: 59 \mathrm{AM}$ \\
\hline & \$Detailed Pathway Analysis GW_FC.xls & $8,169 \mathrm{~KB}$ & Microsoft Excel Worksheet & $8 / 25 / 20049: 18$ AM \\
\hline \multirow{3}{*}{ \pm This folder is Online. } & Detailed Pathway Analysis GW_MC.xls & $10,644 \mathrm{~KB}$ & Microsoft Excel Worksheet & $10 / 12 / 200410: 52 \mathrm{AM}$ \\
\hline & Detailed Pathway Analysis VA.xls & $3,201 \mathrm{~KB}$ & Microsoft Excel Worksheet & $9 / 27 / 20049: 05 \mathrm{AM}$ \\
\hline & (20) GDCF Variability Plots.xls & $2,848 \mathrm{~KB}$ & Microsoft Excel Worksheet & $10 / 12 / 20048: 20 \mathrm{AM}$ \\
\hline Select an item to view its description. & 10W MC Correlations.xls & $554 \mathrm{~KB}$ & Microsoft Excel Worksheet & $9 / 22 / 20046: 16 \mathrm{PM}$ \\
\hline See also: & VA BDCF Variability Plots. $x \mathrm{ls}$ & $93 \mathrm{~KB}$ & Microsoft Excel Worksheet & $10 / 12 / 200411: 29 \mathrm{AM}$ \\
\hline My Documents & VA Correlations.xis & $188 \mathrm{~KB}$ & Microsoft Excel Worksheet & $8 / 25 / 20049: 33 \mathrm{AM}$ \\
\hline My Network Places & Water Interception Fraction.xls & $162 \mathrm{~KB}$ & Microsoft Excel Worksheet & $8 / 26 / 2004$ 5:59 PM \\
\hline My Computer & & & & \\
\hline
\end{tabular}

Figure A-3. List of the Excel Files Supporting this Analysis

The description of the Excel files follows below.

Dependence of GW BDCFs on Inputs.xls-This Excel file contains, in individual worksheets, the graphs and the data used to prepare the graphs that show the dependence of the groundwater exposure scenario BDCFs for selected radionuclides on the values of various input parameters. BDCFs results for the groundwater scenario were copied from the appropriate GoldSim files listed in Figure A-1. The graphs were plotted using averaged values of the independent and dependent variables. If the raw data for individual realizations are plotted, the stochastic variability among BDCFs from the multiple random inputs results in plots that show little discernable trend. To generate a graph illustrating the trend, the results of realizations were averaged to minimize the impact of other variables. The results were sorted first by the value of the independent variable (i.e., the input parameter). Then the input parameter values and the corresponding BDCFs were averaged in blocks of 100 values. The triangle symbols in the graph represent the mean and the error bars represent the uncertainty range for the mean at 95 percent uncertainty interval, calculated as 1.96 times the standard error of the mean, with the standard error expressed as standard deviation of the BDCF values in a block of 100 values divided by a square root of the number of results in a block, that is, $\sqrt{100}=10$.

Dependence of VA BDCFs on Inputs.xls-This Excel file is analogous to the Dependence of $G W$ BDCFs on Inputs.xls except that it applies to the volcanic ash exposure scenario. It also generates graphs showing dependence of the BDCF components on the model input parameters.

Detailed Pathway Analysis GW_MC.xls-This Excel file contains calculations of pathway contributions to groundwater exposure scenario BDCFs for the present-day climate. It also contains pathway results copied from Detailed Pathway Analysis GW_FC.xls to produce plots of pathway contributions for both climates. The file consists of worksheets containing the summary of the environmental transport pathway analysis, environmental transport pathway analysis for selected radionuclides, analysis of the inhalation and ingestion pathway, as well as the graphs showing pathway contributions for individual radionuclides. The results of model realizations were copied into the worksheets from the appropriate GoldSim files listed in Figure A-1. 
Detailed Pathway Analysis GW_FC.xls -This Excel file is analogous to the Detailed Pathway Analysis $G W_{-} M C$.xls except that it applies to the upper bound of the glacial transition climate.

Detailed Pathway Analysis VA.xIs-This Excel file contains calculations of pathway contributions to volcanic ash exposure scenario BDCFs for the present-day climate. The file consists of worksheets containing the summary of the environmental transport pathway analysis as well as the graphs showing pathway contributions for individual radionuclides, environmental transport pathway analysis for selected radionuclides, and analysis of the inhalation pathway. The results of model realizations were copied into the worksheets from the appropriate GoldSim files listed in Figure A-1.

GW BDCF Variability Plots.xls-This Excel file contains several worksheets showing statistics for the groundwater exposure scenario BDCFs and their pathway BDCFs and the graphs illustrating the variability and uncertainty in the BDCFs and their contributing pathways.

GW MC Correlations.xls-This Excel file contains the correlation coefficients calculated in GoldSim for the groundwater exposure scenario BDCFs. Data in this spreadsheet were transferred from the following files:

ERMYN_GW_MC8_C14_SA.gsm, ERMYN_GW_MC8_Tc99_SA.gsm, ERMYN_GW_MC8_I129_SA.gsm, ERMYN_GW_MC8_U233_SA.gsm, ERMYN_GW_MC8_Np237D_SA.gsm, ERMYN_GW_MC8_Pu239_SA.gsm.

VA BDCF Variability Plots.xls-This Excel file contains several worksheets showing statistics for the volcanic ash exposure scenario BDCFs and their component BDCFs and the graphs illustrating the variability and uncertainty in the BDCF components and their contributing pathways.

VA Correlations.xls- This Excel file contains the correlation coefficients calculated in GoldSim for the volcanic ash exposure scenario BDCF components. Data in this spreadsheet were transferred from the file ERMYN_VA_MC8_Sr90D_SA.gsm

Water Interception Fraction.xls - This Excel file produces graphs of interception fraction appearing in Figure 6.2-20. Data in this spreadsheet were transferred from the file ERMYN_GW_MC8_Pu239_SA.gsm 


\section{INTENTIONALLY LEFT BLANK}

